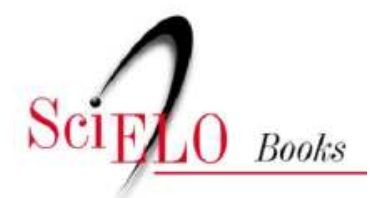

\title{
Histórias de vida e formação de professores
}

\author{
diálogos entre Brasil e Portugal
}

\author{
Inês Ferreira de Souza Bragança
}

\section{SciELO Books / SciELO Livros / SciELO Libros}

BRAGANÇA, I. F. S. Histórias de vida e formação de professores: diálogos entre Brasil e Portugal [online]. Rio de Janeiro: EDUERJ, 2012, 312 p. ISBN: 978-85-7511-469-8. Available from: doi: $\underline{10.7476 / 9788575114698}$. Also available in ePUB from:

http://books.scielo.org/id/f6qxr/epub/braganca-9788575114698.epub.

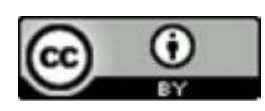

All the contents of this work, except where otherwise noted, is licensed under a Creative Commons Attribution 4.0 International license.

Todo o conteúdo deste trabalho, exceto quando houver ressalva, é publicado sob a licença Creative Commons Atribição $\underline{4.0}$.

Todo el contenido de esta obra, excepto donde se indique lo contrario, está bajo licencia de la licencia $\underline{\text { Creative Commons }}$ $\underline{\text { Reconocimento } 4.0 .}$. 


\section{Histórias de vida e formação de professores: diálogos entre Brasil e Portugal}




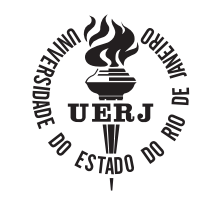

UNIVERSIDADE DO ESTADO DO RIO DE JANEIRO

\section{Reitor}

Ricardo Vieiralves de Castro

\section{Vice-reitor}

Paulo Roberto Volpato Dias

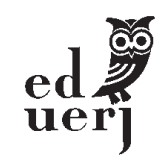

EDITORA DA UNIVERSIDADE DO ESTADO DO RIO DE JANEIRO

\section{Conselho Editorial}


Inês Ferreira de Souza Bragança

\section{Histórias de vida e formação de professores: diálogos entre Brasil e Portugal}

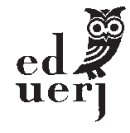

Rio de Janeiro 2012 
Copyright (C) 2012, EdUERJ.

Todos os direitos desta edição reservados à Editora da Universidade do Estado do Rio de Janeiro. É proibida a duplicação ou reprodução deste volume, ou de parte do mesmo, em quaisquer meios, sem autorização expressa da editora.

Rua São Francisco Xavier, 524 - Maracanã

CEP 20550-013 - Rio de Janeiro - RJ - Brasil

Tel./Fax.: 55 (21) 2334-0720 / 2334-0721

www.eduerj.uerj.br

eduerj@uerj.br

\section{Editor Executivo \\ Assistente Editorial \\ Coordenadora Administrativa \\ Coordenador de Publicações \\ Coordenadora de Produção \\ Revisão}

Capa

Projeto e Diagramação
Italo Moriconi

Fabiana Farias

Rosane Lima

Renato Casimiro

Rosania Rolins

Andréa Ribeiro

Shirley Lima

Carlota Rios

Emilio Biscardi

CATALOGAÇÃO NA FONTE

UERJ/REDE SIRIUS/NPROTEC

B813 Bragança, Inês Ferreira de Souza

Histórias de vida e formação de professores:

diálogos entre Brasil e Portugal / Inês Ferreira de

Souza Bragança. - Rio de Janeiro: EdUERJ, 2012.

$314 \mathrm{p}$.

ISBN 978-85-7511-244-1

1. Professores - Formação - Brasil. 2. Professores Formação - Portugal. I. Título.

CDU 377.8(81+469) 
Às professoras dos primeiros anos do ensino fundamental, no Brasil, $e$ às do primeiro ciclo do ensino básico, em Portugal, que, dia a dia, em meio a intensos conflitos e desafios, tecem, com vitalidade e poesia, a educação, a formação e a vida, reafirmando sentidos de antigas lutas que insistem em mobilizar nossos sonhos e projetos coletivos.

A Teutonio Junior e Caio, meus amores.

Aos meus pais, Daleia e Celio; à minha querida irmã Lia; e aos meus pais portugueses, D. Maria Tereza e Sr. Amadeu. 
A vida só é possivel reinventada.

Anda o sol pelas campinas e passeia a mão dourada pelas águas, pelas folhas... Ah! Tudo bolhas que vêm de fundas piscinas de ilusionismo... - mais nada. Mas a vida, a vida, a vida a vida só é possivel reinventada.

(Cecília Meireles) 


\section{Sumário}

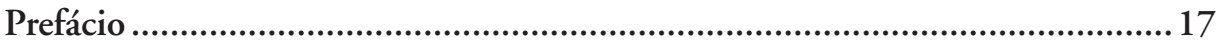

José Bravo Nico

Apresentação: Professores numa outra estética educacional

Capítulo 1: Começando a contar uma história: formação de professores/as no Brasil e em Portugal - tensóes e desafios na busca de uma epistemologia instituinte

Capítulo 2: História de vida nas ciências humanas e sociais: caminhos, definições e interfaces.

Indícios de caminhos trilhados pela história de vida na história da filosofia e como metodologia no campo das ciências humanas e sociais... 37

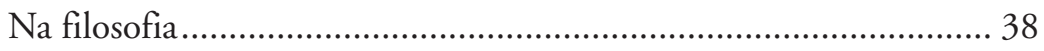

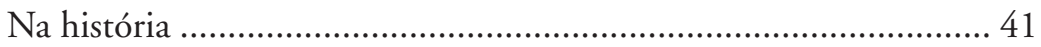

$\mathrm{Na}$ antropologia e na sociologia .................................................. 44

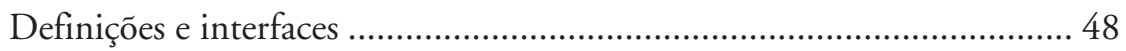

Alguns conceitos.......................................................................... 50

Diversidade metodológica ………................................................. 55 
Capítulo 3: Iniciando o diálogo: um olhar dirigido à literatura educacional

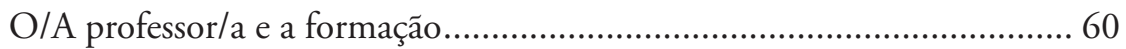

Os/as professores/as, a formação e a pesquisa educacional................ 60

Formação: a tessitura de uma colcha .................................................. 63

História de vida e formação de professores/as ............................................ 69

História de vida e educação ............................................................... 70

História de vida e formação de professores....................................... 74

Um olhar dirigido à polifonia dos aportes teóricos........................... 74

A diversidade metodológica ............................................................. 76

Contribuiçốes das histórias de vida em contextos de

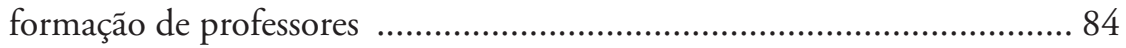

Contribuições no campo educativo e na formação de adultos ......... 84

Contribuições ligadas à formação docente ........................................ 86

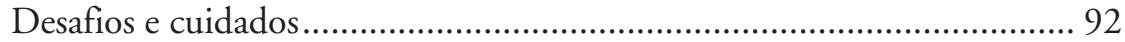

Capítulo 4: Memória, narração e experiência: um "círculo virtuoso" ................95

Pesquisa e educação: a perspectiva da complexidade ................................. 95

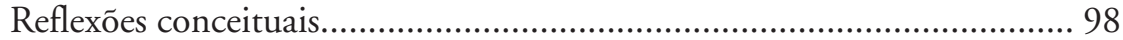

Memória, narração e experiência .................................................... 98

A narrativa como tessitura da intriga: contribuições de

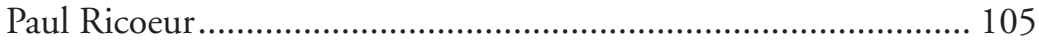

Formação, aprendizagem experiencial e processos identitários........ 110

Abordagem metodológica ...................................................................... 114

Pesquisa-ação, pesquisa-formação e as especificidades da

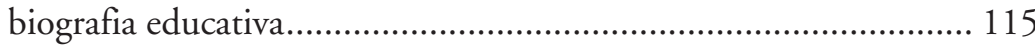

Desafios da interpretação hermenêutica......................................... 118 
Um "círculo virtuoso"

Caminho biográfico-epistemológico da investigação

Contando uma história: "fragmentos autobiográficos"

O livro da vida

A cozinha como metáfora: o preparo da "sopa" e de seus ingredientes

Abordagem metodológica 140

Os contornos. 140

Desenvolvimento da investigação

A construção do roteiro e a contribuição dos professores especialistas

A definição do número de participantes da investigação-formação e composição do grupo 146

O contrato de trabalho: critérios deontológicos. 148

$\mathrm{O}$ registro do não verbal e a transcrição das entrevistas. 151

Apreensão do diálogo, da interlocução: contexto das entrevistas, gestos, entonaçōes, emoções .....

Movimentos da primeira análise de conteúdo

Movimentos da segunda análise de conteúdo

Reflexões 160

Capítulo 6: Trajetórias de vida e formação de professoras portuguesas e brasileiras: suas biografias educativas

Encontro com as professoras: a diversidade de movimentos narrativos .. 162

Trajetórias de vida e formação das professoras: biografias educativas...... 166

Clara: a formação como caminho de encantamento e curiosidade 
Simone: a formação como movimento, pesquisa e experimentação.............................................................................. 176

Histórias de professoras: tessituras da intriga .......................................... 188

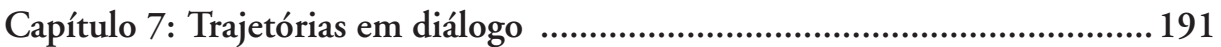

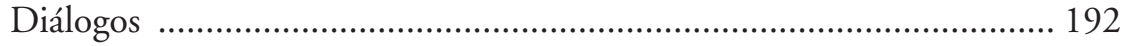

Diferentes configurações da trajetória de vida e formação ............... 192

Formas de ser e de estar: o processo identitário .............................. 195

Memórias polifônicas da vida ....................................................... 200

Memórias da trajetória escolar ....................................................... 210

Memórias da escola primária e continuidade dos estudos ....... 211

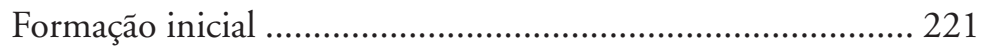

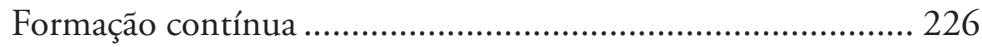

Memórias das experiências profissionais.......................................... 236

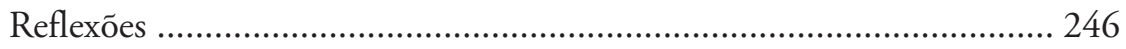

Reflexões (in)conclusivas: a formação como tessitura de intrigas ....................249

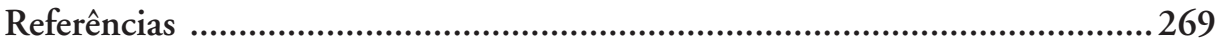

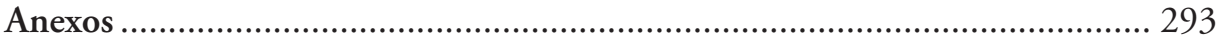

Anexo 1: Roteiro para entrevistas biográficas......................................... 294

Anexo 2: Contrato de trabalho pedagógico-acadêmico............................ 304

Anexo 3: Roteiro de tópicos para reflexão ............................................... 305

Anexo 4: Sugestão de tópicos para interpretação da biografia

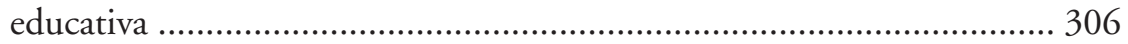

Anexo 5: Sugestão de tópicos para reflexão escrita ................................... 307

Anexo 6: Esquema temático-cronológico ……........................................ 308 
Anexo 7: Gráfico das experiências instituintes de formação

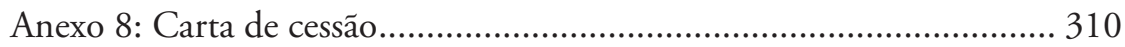

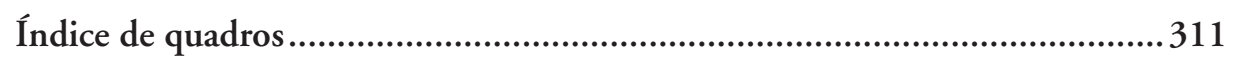

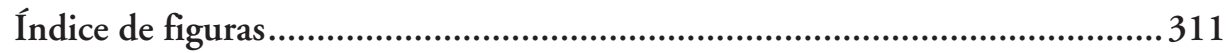

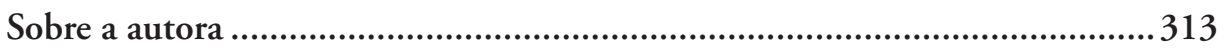



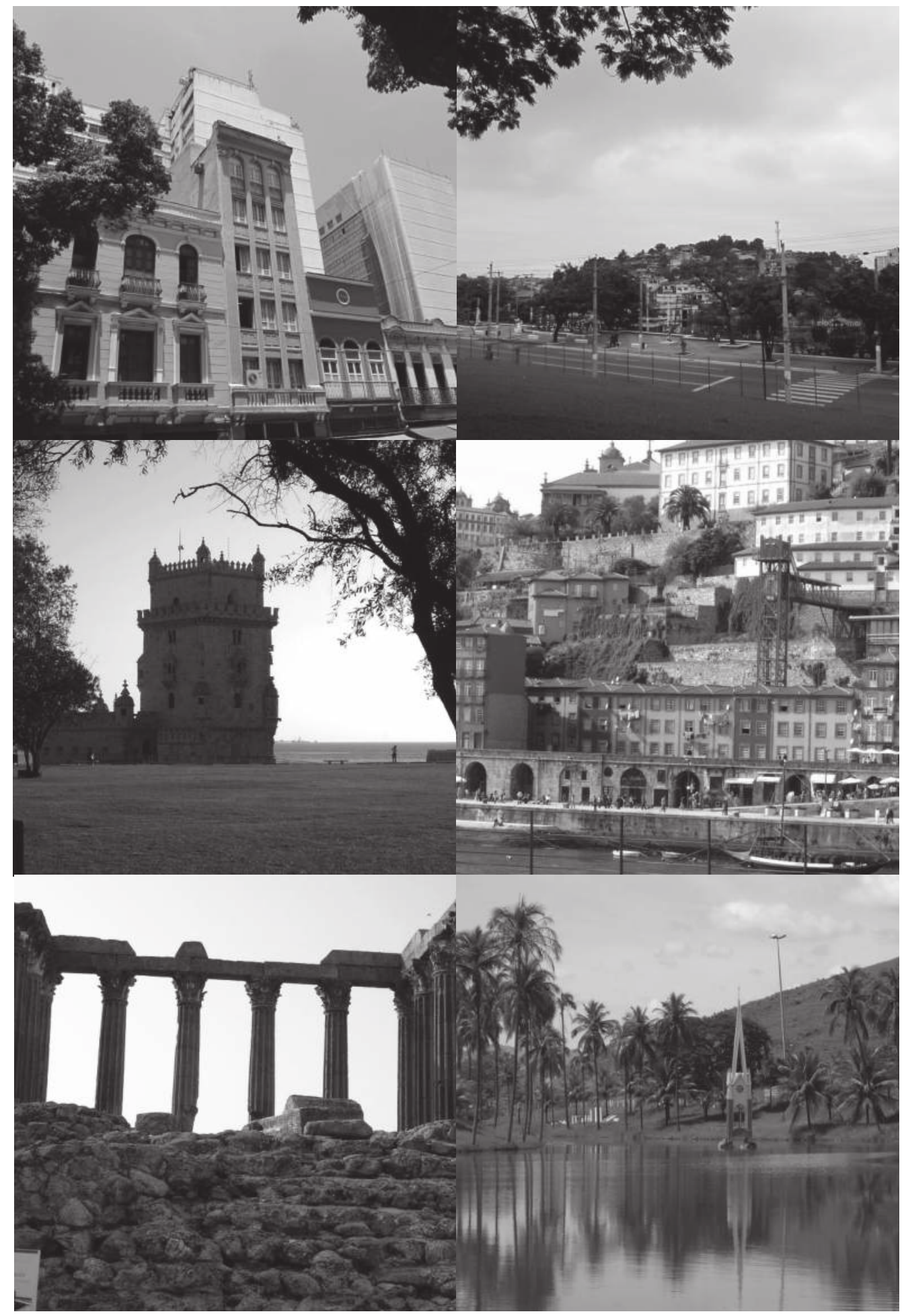


\section{Prefácio}

Ser professor é uma circunstância vital que une milhões de seres humanos em todo o planeta. Mais do que uma questão profissional, a condição de professor remete-nos para uma dimensão que contém valores, atitudes, comportamentos e decisões em que todos os professores encontram um eco unificador, apesar das peculiares manifestações próprias da personalidade e da coordenada geográfica, social, cultural e histórica de cada indivíduo.

A presente obra, que a doutora Inês Bragança nos apresenta, traz-nos um pequeno conjunto de fragmentos desse universo existencial, concomitantemente singular e comum. Ser-se professor é uma circunstância que se constrói através de uma infinita variedade de percursos vitais, em que encontramos diferentes perplexidades: a vocação ou a sua, aparente, inexistência; a formação inicial e contínua e suas diferentes intensidades e modalidades; os episódios vitais edificantes de uma identidade profissional ou iniciadores de uma procura vocacional; o despertar de um ideal e o respectivo reforço; o quotidiano do exercício profissional e respectivas vitórias e derrotas; os dilemas e as suas resoluções.

É esta "trama” existencial que a autora procurou em professores de Portugal e do Brasil e que aqui nos apresenta, de uma forma plena de detalhes e pormenores próprios de quem escutou com atenção e muita sensibilidade as "narrativas" de quem vive e respira a condição de professor.

Percorrer, com a necessária e imprescindível calma, as palavras que descrevem o trabalho de Inês Bragança, saboreando, com tranquilidade, as histórias de vida que aqui estão disponíveis, permitirá a cada leitor conhecer percursos vitais de extraordinária riqueza humana e de enorme potencial de aprendizagem. 
Mas, mais importante que essa viagem pelas vidas dos outros, será, naturalmente, a viagem que cada um de nós voltará a realizar pela sua própria vida. E, se é certo que, nesta viagem, revisitaremos alguns dos argumentos que levaram muitos de nós a sermos professores/as, poderá acontecer que possamos encontrar muitos outros argumentos que nos sedimentam e consolidam essa mesma vontade de continuarmos a querer ser o que somos: professores/as.

José Bravo Nico Évora, Portugal 


\section{Apresentação \\ Professores numa outra estética educacional $^{*}$}

Célia Linhares

Rio de Janeiro, Brasil

O homem é uma corda tensa entre o animal e o além do homem - uma corda sobre um abismo.

Friedrich Nietzsche

Essa epígrafe de Nietzsche pode estremecer um mundo de certezas e dogmas, de permanências e previsibilidades, que se conjuga sem parar com movimentos de altíssima aceleração, recriando matrizes de conformismos ativistas, próprios de uma "turboparalisia", para usarmos uma expressão do pensador Lind (2011). ${ }^{1}$

Essas polarizações, com paradoxos, ambivalências e contradições, infiltram-se em nossa vida diária, empurrando-nos a subestimar experiências, com suas vicissitudes e esperanças, e podendo nos levar a deslizar num mundo linearizado pelos atarefamentos, controlados por modos e medos com que se agenciam subjetividades, além de fortalecer os desígnios que, embora convivam com frestas e pontos de fuga, organizam e modelam sucessos e

\footnotetext{
Para meus adorados viajantes do infinito, Angela, Andréa, Gabriel, Hugo e Bibi. A vocês que me habitam, tornando possível encontrar-nos, vivamente, a cada passo desse dia a dia, feito de inesperados, dedico todos os amanheceres que estão por vir, pelos quais tantos e tantas continuamos nos empenhando. Sua mãe, vovó, sogra e amiga.

1 Michael Lind. The new nationalism and the fourth American revolution. Nova York: Free Press Paperbacks, 1996. Citado por Dorrit Harazim. "A Era da Turboparalisia”. O Globo, 31 dez. 2011.
} 
oportunidades, na tentativa de consolidar os elos de uma organização a que todas e todos deveríamos nos submeter.

Por isso, é tão valioso ouvir Nietzsche nos mostrando a nós mesmos, humanos, em permanente tensão, entre o animal que somos e tudo que nos faz ser um caminho, que se movimenta em devires, muito aquém e além de cálculos lineares e calculáveis.

Assim, podemos ver-nos suspensos, irremediavelmente sem proteção e sem amparo totais, expondo-nos tanto aos acontecimentos que podem nos aproximar dos entusiasmos paradisíacos ou alucinantes quanto daqueles que, ao irromperem brutalmente em nossas vidas, nos estilhaçam e nos mutilam, lançando-nos nos vazios das inexplicaçôes, onde as centelhas daqueles que de nós foram arrancados confirmam suas vidas e iluminam nossos caminhos trepidantes, que se alargam com exercícios de compaixão.

Nietszche se afasta de uma racionalidade fria, para provocar nossa sensibilidade, aproximando-a da complexidade incessante dos movimentos da vida, que não fazem acordos de permanências e estabilidades.

Pelo contrário, essas inquietudes vitais fogem dos pousos estagnantes, preferindo viver ambiguidades, tensões, multiplicidades e contrastes, em fluxos com os quais nos reeditamos historicamente, produzindo rupturas e reinvençóes. Somos uma corda sobre abismos.

Será que essas reflexões passam por perto das análises dos orçamentos e dos cursos para professores, que vêm, ano a ano, crescendo e ampliando seus territórios? Num e noutro são ressaltadas urgências econômicas, promessas de sucesso, aplicações utilitárias e pontuais, insumos para os rankings, sob a fiança de que são imprescindíveis para garantir condições de competitividade no mundo global.

Mas há muito mais a ser visto e ressaltado nesses movimentos de expansão, que nunca são totalmente puros tampouco dominados pelas impurezas. Neles habitam velhos sonhos de uma sociedade brasileira com direito à vida e à educação; sonhos que continuam exigindo reediçôes, convivendo com os embates para definir os rumos do Brasil, atravessados por conflitos e enigmas que não param de se densificar nesse nosso vertiginoso tempo. Afinal, queremos construir uma nação em que caibamos todos e todas, como tão bem cantou Gonzaguinha:

É, a gente quer viver pleno direito

A gente quer é ter todo respeito 
A gente quer viver uma nação
A gente quer é ser um cidadão.

Neste belo livro escrito por Inês Bragança em seu processo de doutoramento, também podemos ler preocupaçōes, que iluminam sua pesquisa e sua vida, que vão muito além de planos e contabilidades escolares e, sem desconsiderar os limites da configuração tangível da escola, sabem valorizar essa tecelagem que, ao potencializar a capacidade criadora dos professores, intensifica as possibilidades de reconhecimentos docentes e pedagógicos, sem os quais não se desenvolve uma educação em que caibamos todas e todos e inteiros, com nossos sonhos e diferenças.

É disto que este livro trata: acordar os continentes de indiferença que seguem adormecidos pelos individualismos de plantão, despertando histórias de professores que possam ir animando a si próprios e a seus estudantes, mobilizando a quem as narra e a quem as escuta, encorajando desejos de compartilhar dores e alegrias; afinal, narrar experiências pode funcionar como um antídoto do medo e da inércia reprodutora, para alimentar liberdade e democracia, que precisam ser vitalizadas por todos nós para a reinvenção de outros mundos, mais amorosos e aprendentes, os quais, insistentemente, estão sendo gestados. Mas nem todos querem esses mundos outros. Pelo contrário.

Por isso, há razões para temores. Os problemas escolares vão se complexificando, quando aplicamos em nossas escolas, já tão amedrontadas diante da vida contemporânea, doses requentadas de velhos tipos de ensino, descarregados de curiosidade e prazer, que se mostram incapazes de arejar os ambientes de aprendizagens por se resignarem com velhos emparedamentos na educação escolar; mecanismos que travam a criação e a autonomia na escola.

Isso significa que insistir em dar mais do mesmo, no que se refere aos processos escolares - o que até agora prevaleceu na formação de professores -, agrava e acimenta velhas tradiçôes que nutrem continuísmos na instituição escolar, mesmo quando elas convivem com ativismos promotores de mudanças; mudanças que facilitam permanências de tantos modelos, como aqueles que se orgulham de elevar a posição de suas escolas nos rankings e de facilitar sucessos escolares que pouco se conectam com as aprendizagens que afirmam a vida em sua urgência de ser incessantemente reinventada. 
Aqui vale lembrar Cecília Meireles, citada como epígrafe por Inês Bragança: "Porque a vida, a vida, a vida, / a vida só é possível reinventada".

Por isso, estou entre aquelas e aqueles que urgem, cada vez mais, não só por mais investimentos na educação escolar e na formação docente, mas também, e sobretudo, por políticas que mobilizem outras formas de pensar (pensar como ação social que envolva corpos inteiros, com atividades de afirmação criadora), as quais, ao encontro da vida, liberem-se das idealizaçôes modeladoras e hierarquizantes que reforçam desprezos por uns e subalternidades por outros, tornando-nos submissos às exigências de segurança, estabilidade e conforto, com sufocamentos das experiências que o viver proporciona e dos riscos que o diferir, o inventar e o singularizar-nos sempre envolvem.

Contudo, de uma maneira ou de outra, todos vivemos experiências e temos de concordar que, para mantê-las e valorizá-las, como um patrimônio existencial e político, é mister elaborá-las permanentemente, como um modo de preservá-las das corrosões que os desprezos, as taxações de insignificância, as advertências dos perigos a serem evitados e as interdições dissimuladas e silenciadas, que se somam às priorizaçôes de um tempo frenético, tantas vezes promovem.

Por tudo isso, Inês Bragança convida-nos a exercícios de uma sensibilidade amorosa, dialogante com a vida e com um tipo de ciência que investe nas dinâmicas de expansão vital, atentando e escutando as demandas que a cada dia se complexificam na educação, entrelaçando-as com ações políticas e estéticas que revitalizam ambientes, expandindo-os e tornando-os mais propícios à reinvenção coletiva de conceitos, de funcionamentos de criação e, assim, contribuindo para enfrentamentos dos atuais desafios e enigmas que permeiam nossas vidas e escolas, como uma forma de potencializar outros mundos que convivem dentro dos nossos.

Portanto, é tempo de, ao mobilizar valores democráticos e estéticos presentes em nosso tempo e em nossa sociedade, ainda que sem condiçôes de vicejar na maioria de nossas escolas, ensaiarmos passos de uma arte de educar capaz de se capilarizar nas aprendizagens e ensinagens, nas leituras e escrituras, nas pesquisas, nas narrações e discussões, sempre experimentando ações político-pedagógicas que se traduzam na mobilização de nossas instituiçóes, para com elas irmos realizando obras de arte, em que todos que as constituem, direta e indiretamente, possam e queiram delas participar. 
Sabemos que muitas políticas educacionais recentes trazem em si convites instituintes de outra cultura, outra educação e outra escola. Todavia, mesmo com suas precariedades e sujeitas a críticas, essas políticas têm investido em movimentos de includência não só numérica, mas que envolvem outras linguagens, outros tempos e espaços, com outras formas de pensar mais sensíveis e afetuais; enfim, outros caminhos de aprender e ensinar, em que as diferenças possam ser tratadas como ferramentas a contrapor-se aos esquemas de manutenção das assimetrias e desigualdades.

Mesmo contando com múltiplas iniciativas políticas, os problemas da educação brasileira ainda têm sido hegemonicamente alojados em registros que não só lhes subtraem os movimentos inesperados dos debates - que, permanentemente, reconfiguram a realidade -, mas também os tornam minimizados em seus entrelaces éticos e estéticos. Daí a forma certeira com que as políticas educacionais vêm submetendo a problemática escolar aos relatos e aos planos, em que sobressaem versões utilitárias e numéricas, alimentando o marketing de classificaçôes e previsões, com metas de uma suposta objetividade fria e calculável, como se o jogo das aprendizagens e ensinagens pudesse ser em "tudo dominado".

Assim, fica mais fácil expor as lógicas dominantes não só como óbvias, mas como portas exclusivas para o sucesso e o êxito, pelos quais valeria a pena sacrificar a própria alegria de criar e compartilhar a construção estética e política da vida escolar, familiar e social. Então, nos planos feitos por poucos, para muitos executarem, é muito frequente o anúncio de caminhos únicos, cabendo a adesão e o enquadramento de todos aos comandos das políticas educativas e escolares.

Ao se respaldarem em formulários - em si mesmos padronizados e padronizadores e, ainda, tidos como exemplos de uma clareza sem limites -, essas políticas nos ameaçam com modalidades discursivas em que as convicçôes, que não deixam passar as aragens das dúvidas e das discussões, acabam minando os espaços de participação do leitor, desqualificando nossas capacidades de pensar e reelaborar o mundo, em nossas tentativas incessantes de dar sentido aos movimentos de nossa vida, com seus entrelaces e interdependências com a própria vida.

Metaforizando esse engendramento do pensamento único, que nem sempre é claro como seus arautos apregoam tampouco evidente por si mes- 
mo, Saramago nos fala de uma cegueira endêmica, que lenta e luminosamente vai obstruindo os processos de vermos e ver-nos nos outros.

Assim, essas políticas da educação, sorrateiramente, nos vão pressionando e seduzindo para aderirmos às formas de subjetivação que desvalorizam processos de diferir e criar outros modos de pensar, como ações includentes de nossas experiências, sensibilidades e afetos, com as quais, ao intervirmos na vida, também nos recriamos, existencial e coletivamente, como obras de arte.

Importa perceber como essas formas de pensar, tão interligadas às experiências - que pulsam aos ritmos das necessidades, dos desejos e dos projetos, atravessados por perigos e sonhos que relampejam, como nos lembra Benjamin -, estão impregnadas das lógicas plurais sempre em devir e também as impregnam.

Esse é um dos nossos mais complexos desafios das políticas educacionais brasileiras, que, ao espelharem as encruzilhadas da nossa educação, minimizam seus traços cartográficos. Estes são feitos com a convivência com movimentos instituintes e, como tal, sempre inconclusos, em que nem faltam uma amplitude capaz de acolher curvas, às vezes, com assombros difíceis de suportar, nem, muito menos, uma porosidade com dimensóes variáveis. São essas aberturas e potências em devir que chamam a participação social escolar, acolhendo e incentivando as ações da cidadania ativa; afinal, numa e noutra habitam instigaçóes, urgências e convites para recriarmos as demandas educacionais como um dos instrumentos para produzirmos, com arte, nossas escolas, como uma das instituiçôes construtoras de nossas vidas.

Isso significa requerer que planos e regulações sejam definidos mais compartilhadamente, com lugares para debater e encontrar pontos em que os conflitos sejam, de alguma forma, encaminhados, transformando-se em processos capazes de aclarar dissensos e potencializar divergências que possam conviver, mesmo sem a ingenuidade de suas reduções, umas com as outras.

Não podemos deixar de ressaltar que, embora haja uma concordância bastante generalizada de que a democracia não será capaz de se expandir e se radicalizar sem que os processos educacionais e culturais se entrelacem num espaço de autonomia, intensificando uma cidadania em que todas e todos possam reinventar-se, incessantemente, recriando nossas instituições sociais e, em especial, nossas escolas, ainda não há uma prevalência das preocupaçôes relacionadas com a escola e a vitalidade do pensar, do educar, do convi- 
ver, do aprender e ensinar como artes vivas, imprescindíveis para forjarmos uma sociedade republicana.

Por tudo isso, uma das maiores contribuições deste livro é a permanente instigação às aprendizagens narrativas em que as ensinagens são fortalecidas pela ética e pela estética que amorosamente são convocadas à produção de conjunções com as causas comuns de nosso povo, confluindo com as lutas da vida e dos viventes. 


\title{
Capítulo 1 \\ Começando a contar uma história: formação de professores/as no Brasil e em Portugal - tensões e desafios na bus- ca de uma epistemologia instituinte
}

\begin{abstract}
[...] ao falar da problemática da pesquisa, hoje em desenvolvimento, ao buscar uma abordagem fundamentada na existência, encontro, no fundo, a necessidade de uma formação menos retórica e externa aos sujeitos, uma formação instituinte de novas imagens, saberes e práticas educativas. Uma formação mais ligada à vida e às suas complexidades (21 ago. 2005).
\end{abstract}

Iniciar a narrativa sobre a investigação que deu origem a este livro nos coloca frente à tarefa de contar um pouco de sua história, em um movimento de voltar-lhe à origem. ${ }^{1}$ Origem, como nos propõe Benjamin (1993), não como busca de um sentido cronológico e linear, mas da densidade do passado no presente, na perspectiva de construção dos projetos de futuro que desejamos.

Esse olhar para o passado indica que os problemas de pesquisa, que se colocaram como foco de análise nos estudos já realizados, foram gestados a partir do entrelaçamento entre o trabalho e a vida (Bragança, 1998, 2001a). Questôes da prática docente se materializaram em pesquisa acadêmica, e, assim, foram surgindo indagações que trouxeram a docência e a construção

\footnotetext{
${ }^{1}$ A noção de origem em Benjamin serve de base a uma historiografia regida por outra temporalidade que não a de uma causalidade linear, exterior ao evento. Trata-se da origem como um salto para fora da sucessão cronológica. Por seu surgir, a origem quebra a linha do tempo, opera cortes no discurso nivelador da historiografia tradicional (Gagnebin, 1994).
} 
de seus saberes para o centro das reflexões, bem como a análise da memória e da narração como possibilidades emancipatórias do ser-professor/a, como ruptura com a racionalidade que percebe a docência reduzida à competência técnica. Observamos, nesses estudos, que a dinâmica viva dos saberes docentes brota do/no cotidiano da escola, saberes que são construídos pelos sujeitos ao longo de suas vidas na articulação de dimensões pessoais, culturais, éticas e científicas.

O retorno à universidade, como professora do curso de pedagogia, ${ }^{2}$ constituiu uma oportunidade de vivenciar esse processo com os/as alunos/ as-professores/as. Questóes pulsantes do cotidiano escolar afloravam nas aulas de filosofia da educação e nos encontros de prática de ensino, e esses lampejos da experiência, juntamente com a memória escolar e os saberes pedagógicos, foram e vão abrindo as possibilidades de vislumbrar a complexa rede de construção de saberes. Saberes/formação que atravessam o processo de construção da docência pelos/as estudantes-professores/as. Saberes individuais/coletivos sobre o ofício docente, desconstruídos e construídos ao longo da trajetória de vida.

Partindo desse amplo contexto de vida e trabalho, a investigação foi-se desenhando numa tessitura de múltiplas mediaçóes e se exprime, nomeadamente, pela necessidade de buscar uma perspectiva de formação que, contrapondo-se à racionalidade técnica, mobilize uma racionalidade sensível, incorporando a vida dos sujeitos, em toda sua complexidade existencial, como componente fundamental do processo formativo. Nesse sentido, tomamos as histórias de vida, por meio das biografias educativas, como uma alternativa metodológica no processo de tematização da própria vida, como espaço-tempo de formação docente, fortalecendo o entrelaçamento entre os acontecimentos biográficos que se foram constituindo como experiências instituintes da formação e que vêm das memórias polifônicas da vida, das experiências docentes e da formação acadêmica. Destacamos as possibilidades da memória e da narração como constitutivas da dinâmica de formação, tendo como referência estes autores: Walter Benjamin, Paul Ricoeur, Pierre Nora, António Nóvoa, Gaston Pineau, Pierre Dominicé, Marie-Christine Josso, Célia Linhares e Elizeu Clementino de Souza.

2 Professora da Faculdade de Formação de Professores da Universidade do Estado do Rio de Janeiro (FFP/UERJ) e do curso de pedagogia da Universidade Estácio de Sá. 
A pesquisa foi desenvolvida por meio de investigação-formação, envolvendo seis professoras do $1^{\circ}$ ciclo do ensino básico, em Portugal, e seis dos primeiros anos do ensino fundamental, no Brasil, e centrou-se em três eixos de análise que articulam, também, questōes que buscamos discutir: o trabalho com as histórias de vida, em contexto de formação de professores/ as, pode contribuir na busca de uma racionalidade mais humana, sensível e partilhada? Qual o sentido da rememoração no processo permanente de formação, de construção de saberes, de reconstrução dos projetos de futuro pessoais e coletivos sobre a vida e a profissão? A experiência narrativa pode tornar mais visível e, ainda, potencializar as diversas dimensões da trajetória de vida e formação dos professores/as, nomeadamente o entrelaçamento entre memória, experiências docentes e formação acadêmica? Quais as potencialidades das biografias educativas, em contextos de formação, como caminho de elaboração pessoal/coletiva do testamento da docência e de sua afirmação como "lugar de memória"?

Quanto ao primeiro eixo da investigação, observamos que para as professoras a participação na pesquisa foi uma oportunidade de viver a experiência narrativa do tempo como "tríplice presente" (Ricouer, 1994, p. 28) - em cada encontro, presente, passado e futuro se entrelaçaram, por meio de perspectivas, lembranças e projetos. A narrativa das experiências instituintes de formação possibilitou uma atuação propositiva pelas professoras, na construção de sentidos para a trajetória de vida e formação; o movimento de constituição de uma "história que pudesse ser seguida" (Ricouer, 1994, p. 102) exigiu um trabalho laborioso de tessitura de intrigas, traduzindo $a$ experiência narrativa em formação.

O segundo eixo aponta a análise das diversas dimensões da trajetória de vida. A história de cada professora participante tece experiências que entrelaçam aprendizagens que vêm do âmbito pessoal, da trajetória de formação acadêmica e profissional em uma complexa configuração. Assim, encontramos vestígios de que o processo formador se torna inteligível em uma perspectiva que entretece os diferentes episódios em tessitura, em que as intrigas são articuladas na experiência narrativa como uma história que pode ser seguida.

Quanto ao terceiro eixo, o desenvolvimento da investigação-formação também foi abrindo canais para uma aprendizagem partilhada, na tematização de percursos de vida, reafirmando o sentido da docência como "lugar de memória" (Nora, 1993) e a contribuição do registro da história de vida como 
"testamento" (Arendt, 1972), abrindo a possibilidade de que outras pessoas, na leitura desses testamentos, possam também vivenciar uma experiência de aprendizagem que transforme biografia em herança.

Mas "a pouco e pouco"3 o desenvolvimento do trabalho trouxe um eixo que se foi afirmando: o sentido dialógico da investigação e da formação. A realização do doutoramento na Universidade de Évora e o desenvolvimento da pesquisa, envolvendo professoras portuguesas e brasileiras, indicaram um importante sentido de diálogo, no encontro de caminhos trilhados pela escola, pela docência e a formação de professores, nesses dois países. Reafirmamos, nessa perspectiva, uma aprendizagem que se dá quando nos confrontamos com o outro, ao qual, dialeticamente, nos ligamos e nos distanciamos, mediados por desejos, lutas, conflitos e desafios comuns e singulares.

É essa dinâmica dialógica que nos permite perceber "sotaques"‘ que vêm de diferentes cidades portuguesas e brasileiras, e é importante exercitar, por essa razão, na leitura do texto, a escuta atenta, às vezes silenciosa, mas sempre dialógica, buscando perceber a melodia que vem da experiência gerada pela pesquisa e que se abre como convite de experiência também aos leitores.

A problemática da pesquisa se colocou, assim, pela busca de uma formação ancorada em uma epistemologia mais sensível que acolha as múltiplas dimensões que envolvem a construção dos saberes e da própria vida. Embora aumentem as pesquisas em educação, políticas e regulamentações sobre o ensino, os processos escolares e formativos continuam áridos e pouco férteis. Encontramos, nesse campo, um complexo conjunto de fatores e, com Linhares (2000), perguntamos se, diante desses dilemas, os processos de formação serão reeditados, remontados ou apropriados para uma reinvenção à altura da complexidade da vida e de suas exigências éticas. Precisamos, ainda hoje, unir-nos a tantos educadores, professores, pedagogos que antes de nós lutaram pela reinvenção cotidiana da escola e da formação docente. É preciso retomar lutas vencidas pela racionalidade triunfante, buscando, por meio de

3 Coloco a expressão entre aspas porque foi aprendida pela investigadora nos longos diálogos com as professoras portuguesas, participantes da investigação.

4 A expressão "sotaques" provém de reflexão tecida pelo professor doutor José Bravo Nico, em comunicação oral proferida no III Encontro Regional de Educação: Aprender no Alentejo, realizada no dia 24 de maio de 2005, na Universidade de Évora - Portugal. 
açôes singulares, mas entranhadas no contexto sócio-histórico, alternativas de formação mais dialógicas e humanas.

Há premência de pontes para a reinvenção da escola e para a formação de seus profissionais. Pontes entre saberes, noçōes, ideias, narrativas, memórias, disciplinas, habilidades, açôes e acontecimentos, todas visando refundar a escola em outros moldes que a predisponham a trabalhar por uma cultura mais includente, mais prazerosa e compartilhada (Linhares, 2001, p. 10).

A escola e a formação buscam essas pontes, um entrelaçamento complexo entre as diversas dimensões formativas, entre saberes acadêmicos e experienciais, memórias e narrativas, práticas e teorias. As dinâmicas de formação inicial e contínua têm, entretanto, indicado um movimento de "aceleração" (Nora, 1993), o qual faz um esforço de demissão da experiência em sentido pleno, coletivo - demissão da partilha, do encontro, da vida.

A aceleração tanto está colocada no sentido das políticas públicas e dos processos curriculares quanto envolve aqueles e aquelas que procuram a formação. Os cursos e programas caminham em um processo que se quer cada vez mais veloz, que assegure ou que dê maior possibilidade de emprego, ou, ainda, que contribua para a progressão na carreira.

No interior dos processos formativos, registramos, muitas vezes, uma lógica fragmentária do conhecimento e perspectivas didáticas com base na transmissão de conteúdos. Em um painel sobre os cursos de formação inicial em Portugal, Bidarra (2002, p. 159) destaca como um dos problemas nesse campo a "demasiada adesão a um modelo transmissivo", afirmando que este não contribui para a modificação das representações, competências, disposiçóes pessoais, que são, segundo a autora, os objetivos de toda prática de formação. Campos (1995, p. 32) também afirma que a metodologia predominante na formação de professores segue o paradigma transmissivo.

No contexto brasileiro, Linhares nos ajuda a sublinhar os baixos níveis de aprendizagens formativas, dificuldades que travam a formação de professores:

Como uma interdependência dos processos metodológicos construídos, fomos expandindo nossa curiosidade no sentido de perceber as dificuldades que travam a formação de professores, constatadas em pesquisas e nas práticas vivenciadas e que poderíamos resumir da seguinte maneira: por que 
tanto ensino corresponde a tão baixos níveis de aprendizagens formativas? (2005a, p. 11)

Nesse mesmo sentido, Campos, em um balanço sobre a formação de professores em Portugal, destaca:

Como sublinha Nóvoa (1992a), se a história da formação de professores nos últimos vinte anos pode ser contada como uma história de sucesso (desenvolvimento de instituições e cursos e profissionalização da maioria dos docentes em exercício), também pode ser contada como uma história de incapacidade 'para melhorar significativamente a formação científica e as competências profissionais dos professores' (1995, p. 35).

Os indícios da pesquisa educacional levam-nos a perceber que a racionalidade em que estão assentados nossos cursos de formação inicial e contínua, muitas vezes, não dá ênfase à vida e às complexidades existenciais. Colocando-se a formação longe da vida, temos dificuldade de tocar os sujeitos, de aflorar a experiência, favorecendo a vivência pontual e fragmentada, que não encontra potência para produzir transformação nos sujeitos e nas escolas. Uma das perspectivas que já se vem colocando, em diversas pesquisas e práticas, é a busca de uma formação fundada em uma epistemologia mais humana e, portanto, necessariamente mais sensível e dialógica, como nos ensina Freire (1992).

Nesse sentido, é possível observar movimentos capilares que caminham para a ruptura e, além do discurso, conseguem instaurar práticas instituintes e, talvez, novas racionalidades. É possível encontrar, em muitos espaços, tanto no Brasil como em Portugal, a afirmação de uma pedagogia que se procura traduzir em uma formação mais humana, amorosa, compartilhada, com a incorporação dialética da complexidade da prática, articulando movimentos de reflexão, pesquisa e formação.

Observamos que a vida e a formação docente trazem um movimento em que se encontram a formação acadêmica institucional, a história familiar e pessoal/de vida, opçóes e trajetórias religiosas, a memória escolar e tantas outras dimensões que vão tecendo o ofício docente. São os acontecimentos biográficos que, de forma muito particular, e, ao mesmo tempo, prenhes do coletivo, vão mobilizando determinadas formas de ser e de estar na vida e na docência. É preciso trazer a potência dessas múltiplas dimensões para o centro dos pro- 
cessos formativos e, como nos ensina Nóvoa (1991, p. 70), encontrar espaços de interação entre as dimensões pessoais e profissionais.

Se visualizamos anteriormente, de forma geral, os movimentos de formação docente e encontramos um campo de tensões entre racionalidades que desejam nomear e afirmar as concepções e práticas da formação, essas tensões também se materializam quando focalizamos o/a professor/a e seu trabalho na escola. O olhar dirigido à história da educação brasileira e portuguesa vai delineando diferentes concepçóes sobre o/a professor/a; a docência vai assumindo diferentes matizes e configurando uma trama de múltiplos fios. Essa dinâmica pode ser percebida tanto em um olhar macro como em um olhar dirigido à particularidade dos sujeitos que produzem a profissão docente em seu cotidiano. São múltiplas perspectivas que apontam, em cada momento histórico e em cada contexto, certa configuração caótica e fragmentária, que se manifesta de diferentes formas nos sonhos e projetos de cada professor/a e na maneira como se constrói a profissão docente.

Confrontamo-nos com uma produção histórico-social sobre a docência, que aponta relaçôes dialéticas com as experiências particulares, traduzindo a apropriação-recriação subjetiva dos movimentos da sociedade. Se nos defrontamos historicamente com referências balizadoras sobre o "ser" professor/a, que indicam dimensões profissionais e pessoais, teóricas e metodológicas, em contraposição, na escola, observamos sujeitos que constroem a profissão docente, muitas vezes, rompendo com o instituído.

A memória e a narração exercem importante papel nesse processo. A memória traz o registro vivo de diferentes experiências sociais da docência que foram se acumulando ao longo da trajetória não só histórica da profissão, mas também pessoal de cada professor/a. O trabalho com as histórias de vida vem como possibilidade de contraposição aos movimentos de aceleração da vida, da formação e da docência, buscando um processo de formação e construção de saberes que se deseja mais humano, existencial, partilhado - é a interrupção do tempo "cronológico" e "vazio" (Benjamin, 1993) e o resgate da multiplicidade do tempo e de experiências plenas, instituintes. Tomamos o sentido da experiência plena pela natureza coletiva de sua construção e a narração como caminho de partilha e recriação dessas experiências. 
As questôes e a problemática anteriormente anunciadas levaram-nos a uma investigação que tomou as histórias de vida não só como possibilidade metodológica, mas como caminho para repensar a formação de professores com base em uma epistemologia instituinte, na qual saberes científicos, culturais, pedagógicos e existenciais se encontram em polifonia. $\mathrm{O}$ desenvolvimento do trabalho corporificou, entretanto, o sentido de movimento e de construção/reconstrução permanente da pesquisa, ou seja, os indicativos do projeto de investigação foram tecidos no dia a dia de uma trama entre Brasil e Portugal.

É um pouco assim - a pesquisa como uma deliciosa 'sopa de pedra'. São muitos os ingredientes e, em sua preparação, cada um deles precisa de um tratamento específico, de um tempo de cozimento, de uma panela adequada. E, se essa sopa tem uma receita, em conversa com minhas amigas portuguesas, percebi que o que caracteriza sua própria origem é a possibilidade de fazer um saboroso prato, quente e inspirador, a partir do que temos, dos ingredientes de que dispomos e que, alquimicamente, vão dando sabor e sentido. É preciso saber administrar e viver o tempo de cada um dos ingredientes da pesquisa, que juntos, dialeticamente, se articulam e dão sabor ao trabalho (1ำ nov. 2005).

Pesquisa sonhada no Brasil, desenvolvida lá e cá, no diálogo sobre a vida, a sociedade, as complexidades da escola e da formação de professores em Portugal e no Brasil. Por uma professora que, como estrangeira, espreita, sente a forma de viver e produzir a docência de professoras do $1^{\circ}$ ciclo do ensino básico em Portugal e que, na realidade brasileira, tão próxima, tão conhecida, procura o estranhamento, as vozes silenciadas de professoras do ensino fundamental. Os ingredientes dessa configuração metodológica foram se dando aos poucos, no ir e vir, no refletir, no fazer e no refazer do plano de trabalho, articulando revisão de literatura, estudo do referencial teórico-metodológico e desenvolvimento da pesquisa-formação, por meio de entrevistas biográficas. Assim como na dinâmica de preparação da "sopa de pedra" encontramos uma dialética entre o previsto na receita, as alterações feitas a partir da disponibilidade dos ingredientes e, finalmente, os sabores do prato, na pesquisa, vivenciamos a dialética entre o projeto inicial, o sentido vivo e pulsante de seu desenvolvimento e sua escrita acadêmica. 
É preciso, ainda, destacar a presença significativa do "livro da vida".5

O termo 'livro da vida', como parte integrante da presente pesquisa, busca trazer a intensidade dos caminhos percorridos ao longo do processo. É 'livro', pois propõe o registro das 'idas e vindas', e, apesar de intrinsecamente ligado a todo movimento da pesquisa, apresenta certa independência do formalismo acadêmico: não se coloca como capítulo ou item constitutivo da tese, mas como espaço de autorreflexão sobre a pesquisa. Sua proposta é o relato, a narrativa e, nesse sentido, é mesmo 'da vida'; traz a densidade de pulsações que vão se apresentando em diferentes dimensões, entrelaçando visões e emoções de cada momento/ciclo desse processo (set. 2004).

A escrita do livro constituiu espaço-tempo de reflexão e foi acompanhando todo movimento da pesquisa. Seus registros, em primeira pessoa, trazem a intensidade da experiência viva da pesquisa, rompendo com a cronologia, e apresentam a própria pesquisa como experiência biográfica de formação.

A transformação da tese em livro exigiu algumas adaptaçóes e a escolha de um caminho a seguir. Optamos por manter o fio condutor do trabalho, mas a necessidade de redução do texto levou-nos a registrar as biografias educativas de apenas duas professoras participantes, uma portuguesa e outra brasileira. $\mathrm{O}$ capítulo destinado à análise dialógica entre as trajetórias traz, entretanto, aprendizagens que vieram da história de vida de cada uma das 12 participantes. No mais, o presente texto mantém o conteúdo da tese apresentada na Universidade de Évora. ${ }^{6}$

Consideramos cada capítulo deste livro uma síntese de estudo e pesquisa. Nesse sentido, são apresentados, por um lado, em sua singularidade, ou seja, como dimensão do estudo que traz em si uma contribuição de análise específica, e, por outro, pela articulação e pelo diálogo entre eles. Tendo sina-

\footnotetext{
5 "Tomo emprestada a expressão livro da vida do educador francês Célestin Freinet (1896-1966), que desenvolveu, com os alunos, a proposta de um registro diário das experiências da sala de aula e da vida - um registro marcado pela liberdade de expressão, que incluía texto, pintura e desenho" (set. 2004).

6 Tese defendida no dia 15 de junho de 2009, na Universidade de Évora - Portugal, sob a orientação do professor doutor José Bravo Nico.
} 
lizado, desse modo, as motivações iniciais e a problematização, fica o convite à leitura e à atribuição de sempre novas possibilidades de sentidos. ${ }^{7}$

7 Registramos que a linguagem escrita deste livro materializa sua dimensão dialógica, pois deixa transparecer a polifonia do português de Portugal e do português do Brasil. 


\section{Capítulo 2 \\ História de vida nas ciências humanas \\ e sociais: caminhos, definições \\ e interfaces}

Indícios de caminhos trilhados pela história de vida na história da filosofia e como metodologia no campo das ciências humanas e sociais

Este capítulo nos chama a um mergulho na história das histórias de vida. Desde o desenvolvimento da dissertação, conceitos que envolvem memória e narrativa passaram a fazer parte de nossas preocupações de investigação e, também, da prática no campo da formação de professores/as. Ao iniciar os estudos no doutoramento, colocamo-nos, inicialmente, frente à tarefa de inventariar caminhos percorridos por essa abordagem teórico-metodológica no campo das ciências sociais e no campo educativo.

A história de vida apresenta-se, em primeiro lugar, como prática social e aparece na transmissão/recriação da cultura, por meio das narrativas de pais para filhos, das histórias da família e da comunidade - são as práticas intergeracionais de comunicação do testamento construído pela comunidade. O grupo, sentado à roda para relato das histórias tecidas socialmente, é uma marca da forma propriamente humana de produção de conhecimentos e constitui o registro espontâneo das narrativas orais de vida. Além da prática oral, encontramos a produção e a preservação de objetos - como cartas, lembranças e baús de memória - afirmando-se como depositários da história individual/coletiva. 
Pineau e Le Grand (1993) destacam as práticas culturais que assumem o papel de constituição e partilha dos marcos da memória do grupo, como comemorações, histórias da coletividade, biografias e autobiografias, o audiovisual e o cinema, recursos que se vão "arquivando" e produzindo uma memória externa ao grupo.

Essa perspectiva espontânea foi assumindo, posteriormente, forma de gênero literário. $\mathrm{Na}$ antiguidade clássica, os diálogos de Platão são ilustrativos da utilização literária da perspectiva biográfica. Já o gênero autobiográfico, muito ligado à cultura ocidental, teve seu marco e desenvolvimento mais intenso a partir do século XIX (Pineau e Michèle, 1983, pp. 122-3). Além de sua forma espontânea e literária, as narrativas de vida, por meio de biografias ou autobiografias, constituem uma metodologia de pesquisa nas ciências sociais.

A prática da narrativa de vida, como possibilidade de partilha e compreensão do próprio sentido da vida e da história pessoal e coletiva, está colocada no percurso da filosofia e nas práticas sociais amplas como movimento humano, razão pela qual essa abordagem veio tomando diferentes contornos metodológicos nas ciências humanas e sociais. Buscamos no presente capítulo, por meio da contribuição de diferentes autores, trazer os fios condutores das perspectivas teórico-metodológicas adotadas.

A incorporação das histórias de vida como caminho metodológico expõe, para as ciências humanas e sociais, o desafio de trabalhar fora do quadro lógico-formal e positivista, reenviando o olhar para uma perspectiva aberta à incorporação da subjetividade como elemento fundamental da constituição epistemológica do saber nesse campo do conhecimento, já que fundada na interação social, no olhar do sujeito. É preciso, segundo Ferrarotti (1990, p. 56), buscar os fundamentos epistemológicos dessa abordagem na razão dialética e histórica, na praxis das relações entre indivíduo e sociedade. Nesse mesmo sentido, Pineau e Le Grand (1993, p. 37) afirmam que as histórias de vida não se reduzem a um método, mas questionam as ciências humanas em sua fundamentação epistemológica. A presente análise busca, portanto, indícios dos diferentes movimentos dessa abordagem.

\section{Na filosofia}

Contar, narrar histórias pessoais e coletivas é uma prática propriamente humana, a qual revela o lugar fundamental da partilha na construção dos 
modos de ser e de estar no mundo. O debruçar sobre as histórias de vida nos leva, assim, a olhar os caminhos trilhados pela filosofia, tematizando o ser humano e suas reflexões ao longo do processo histórico.

Encontramos as narrativas de vida na Grécia antiga. A reflexão filosófica desloca-se da natureza e focaliza o homem em seu processo de conhecer o mundo e a si mesmo. A proposição "conhece-te a ti mesmo e tu conhecerás o universo e os deuses" convida-nos a um movimento de análise, a um olhar para o interior dos processos de constituição dos saberes. Um movimento que não é feito de forma isolada, mas que conta com a presença dialógica do outro, daquele que, como "amante da sabedoria", conduz o discípulo ao conhecimento. Um olhar para o interior do sujeito na busca de um conhecimento de si, articulado ao conhecimento "do universo e dos deuses". Um saber tecido na parceria do coletivo e na busca de uma formação ecológica, porque, sendo ampla, tem como finalidade não a si próprio, mas a dialética entre o individual e o coletivo.

Nesse contexto, encontramos, na maiêutica socrática, a imagem de um saber autobiográfico - é o sujeito que esquadrinha suas vivências e experiências à procura das referências para seu agir sobre o mundo e com as pessoas. Pineau e Le Grand (1993, p. 22) identificam a "bios", no mundo grego clássico, especialmente com a emergência dos filósofos do século IV a.C. Tomando como perspectiva uma prática pedagógico-filosófica, buscam o conhecimento do universo e dos deuses por meio do conhecimento de si, da arte de falar de si e da vida em suas complexidades.

Em um momento de olhar para o infinito e para os dogmas eclesiásticos como regras definidoras da vida, encontramos, na autobiografia de Santo Agostinho, uma busca da transitoriedade da vida dos homens, em seus limites pessoais e temporais. Percebemos em suas Confissóes uma dimensão temporal não essencialmente ligada ao passado, nem simplesmente projetiva, mas aberta a gêneses e novos começos (Pineau e Le Grand, 1993, pp. 23-4).

Ainda na Idade Média, as canções procuravam os fatos significativos do passado, eventos de natureza "política", "amorosa” ou "histórica". No século XII, a palavra "história" vem designar a "representação figurada”, e surgem as crônicas e genealogias. No século XIV, registram-se os gêneros literários que buscavam trabalhar a dimensão temporal da vida, a emergência do jornal, das memórias (Pineau e Le Grand, 1993, pp. 25-6). Con- 
tudo, é importante ressaltar que eram poucas as oportunidades de o homem comum analisar sua própria vida e eram raros os leitores e escritores. A dinâmica da vida familiar, da religiāo, do cotidiano inscrevia "a vida pessoal nos olhos da comunidade”, o que não favorecia um olhar dos homens e mulheres sobre si mesmos (Souza, 1987, p. 121).

As alterações econômicas, políticas e culturais vão progressivamente possibilitando o aparecimento do espaço privado, a individualização dos processos da vida cotidiana. Com o Renascimento e o Humanismo, encontramos um momento fértil para o aflorar do homem, de sua subjetividade e, dessa forma, multiplicam-se os gêneros de narrativas de vida. São desse período a narrativa de acontecimentos da vida diária, os jornais de viagem, as comemorações. No século XVI, Michel Montaigne, tomando sua subjetividade como referência, escreve fragmentos da vida nos quais procura articular suas diferentes leituras. No século XVIII, verificamos ainda, como marco desse gênero, as confissões de Rousseau (Pineau e Le Grand, 1993; Souza, 1987).

O subjetivismo epistemológico, característico da modernidade, coloca o homem no centro do processo de construção do conhecimento e favorece o aparecimento da autobiografia como gênero literário. Nesse período, registram-se na Europa uma produção intensa de memórias, histórias de vida e, na Alemanha e na Inglaterra, a utilização da palavra "autobiografia”. Pineau e Le Grand (1993, p. 29) afirmam que Lejeune analisa esse fenômeno como o surgimento original da autobiografia, mas criticam essa proposição, ao considerarem que a história de vida manifesta-se desde a antiguidade clássica.

No século XX, com o fortalecimento das ciências humanas, vamos encontrar novas formas de produção das narrativas de vida e das publicações nesse campo (Pineau e Le Grand, 1993, p. 32). A análise histórica realizada por Pineau e Le Grand (1993) permite perceber o amplo movimento das histórias de vida ao longo do caminhar histórico. Diferentes modalidades foram sendo constituídas, passando por confissões, jornais íntimos, cartas, correspondências, livros, livros de família, ensaios, cançôes, genealogias, memórias, lembranças, jornais de viagem, efemérides, anais e crônicas. São múltiplas as manifestações narrativas, o que aponta sua natureza ontológica, ou seja, a expressão da vida como parte do estar de homens e mulheres no mundo, com as pessoas e com a natureza. 


\section{Na história}

Aqui, a perspectiva das histórias de vida vem no bojo de uma abordagem metodológica específica - a história oral. A construção do conhecimento histórico tem como referência não apenas os documentos escritos, mas a participação e o ponto de vista dos sujeitos envolvidos nos eventos e contextos históricos. Nesse aspecto, o foco pode recair na totalidade da vida do sujeito ou em momentos específicos e se funda, essencialmente, na narrativa oral. O estudo da história de vida não apresenta, a princípio, um fim em si mesmo, mas focaliza a contribuição que a história de vida específica pode dar para a compreensão de determinados fatos, momentos ou contextos históricos.

Thompson (1998) analisa o caminho percorrido pela história oral no interior da própria história, destacando um período inicial de ênfase na tradição oral, a emergência e a hegemonia do documento escrito e o retorno da narrativa oral como fonte de pesquisa.

A narrativa de vida individual e coletiva faz parte da forma propriamente humana de construir/recriar conhecimentos, de preservar a memória, de criar as identidades, de atribuir a objetos e lugares valor simbólico. A tradição oral é, então, a primeira forma de história; uma história viva e pulsante, acessível a todos os membros da comunidade. Nas aldeias africanas, um membro do grupo distinguia-se por seu papel de homem-memória, o griot da África, mas toda comunidade era envolvida no movimento de partilha e construção da história. O homem-memória registra os fatos históricos da comunidade, os interpreta e os narra - uma história aberta, em que todos os membros do grupo estão presentes nos fatos narrados e se sentam à roda para ouvir. No entanto, o relato oral como testamento da história foi perdendo seu lugar frente à emergência do escrito, que assume a hegemonia de fonte histórica privilegiada.

O processo de rebaixamento da tradição oral e ascensão do documento escrito, na Europa Ocidental, deu-se de forma lenta. Os primeiros textos escritos, que, segundo Thompson (1998), remontam a aproximadamente 3 mil anos, buscaram registrar as tradições orais postas na comunidade, tanto do passado como do presente. Cinco séculos antes de Cristo, Heródoto interrogou testemunhas oculares para a constituição da história. Já os historiadores do Iluminismo tornaram-se cada vez mais céticos em relação à tradição, que foi sendo identificada com as fábulas. Tornou-se, pois, necessário um 
trabalho de investigação com reconhecida comprovação dos fatos. A expansão das fontes impressas, desde o século XVIII, trouxe grande contribuição para a produção histórica. A partir do século XVII, observamos uma diversidade de textos, como o romance histórico e a biografia, e, no século XIX, o florescimento de autobiografias da classe operária na Grã-Bretanha, ligada à atividade religiosa e política.

No contexto do século XIX, a história entra em um processo de especialização crescente, por meio da utilização de trabalho de campo e levantamentos estatísticos. Notamos ainda a afirmação dos historiadores como classe, categoria profissional recrutada por meio da formação acadêmica. A dimensão profissional do trabalho do historiador articula-se à força do documento escrito como fonte de pesquisa, e a história oral passa, nesse contexto, por um período de grande rejeição. Thompson (1998, p. 78) destaca o movimento de recolha do folclore por toda a Europa e o Romantismo como reações ao racionalismo e à hegemonia do documento escrito. Assim, estava dada a possibilidade de uma nova interpretação do fazer histórico. Entretanto, apesar de indícios favoráveis, o século XIX vai ser caracterizado efetivamente por uma busca cientificista e, de forma geral, pela rejeição da história oral.

O século XX, contudo, vai trazer novas formas de organização da vida social, e o aparecimento e o desenvolvimento de tecnologias questionam a hegemonia do escrito. Nesse momento, registramos a importante contribuição dos estudos antropológicos e sociológicos, especialmente por meio da Escola de Chicago, e observamos uma mudança paradigmática no interior das ciências sociais e humanas que influenciou diferentes campos do conhecimento (Thompson, 1998, p. 85).

Na história, essa viragem tem seu referencial na Escola dos Annales. ${ }^{8} \mathrm{~A}$ "história nova", como se designou essa tendência, traz em sua proposta uma rejeição do paradigma simplificador, dos métodos tradicionais de investigação e da concepção tradicional de história. Tal abordagem, bastante fértil no campo historiográfico, afirmou-se com a introdução de novos objetos, abordagens e problemas, produzindo uma ressignificação com a emergência

\footnotetext{
8 A partir dos anos 1930, a história passa por férteis inovaçôes, com a criação da revista (e de um grupo de trabalho) Annales. "Sua convocatória principal pode ser assim resumida, nas próprias palavras de L. Febvre: 'Para fazer história, virem resolutamente as costas ao passado e, antes de mais nada, vivam. Envolvam-se na vida”' (Lopes, 1989, p. 129).
} 
de fontes alternativas ao documento escrito, como a revalorização do depoimento oral e das imagens (Franco, 2002, p. 15).

Buscamos, a partir de uma crítica à ênfase dada à dimensão econômica e das estruturas sociais, debater questôes históricas, como "as atitudes perante a vida e a morte, as crenças e os comportamentos religiosos, os sistemas de parentesco e as relaçôes familiares, os rituais, as formas de sociabilidade, as modalidades de funcionamento escolar etc." (Chartier, 1990, p. 14).

Temos, nessa perspectiva, a produção de uma história que traz à luz os que foram silenciados - os vencidos, como afirma Benjamin (1993) -, os que tiveram sua versão da história sufocada pela historiografia oficial: as mulheres, os operários, os professores. $\mathrm{O}$ foco volta-se para a micro-história, o cotidiano e as dinâmicas locais. Não interessam apenas os movimentos da política educacional como um todo, mas a materialidade desta no chão da escola, na vida de seus professores e alunos. Encontramos uma perspectiva que valoriza os percursos individuais e a subjetividade (François, 2001, p. 4).

Burke (1992, p. 10) destaca questôes que nos ajudam a caracterizar essa perspectiva de análise. Há um interesse por toda atividade humana, uma preocupação com a história social e cultural, com "a história vista de baixo", ou seja, com as contribuiçôes de pessoas comuns; uma incorporação de várias fontes que incluem evidências orais, visuais e estatísticas.

Deparamo-nos, então, com um movimento permanente entre a dimensão teórica e técnica, pela articulação entre prática, metodologia e teoria na produção do conhecimento histórico. Ferreira e Amado (2001) sinalizam os principais focos de trabalho dessa metodologia, destacando: o testemunho oral como núcleo da investigação; a ligação com a história dos vencidos; a subversão da tradicional relação entre sujeito e objeto, pois também o entrevistado é sujeito das emoçôes e do cotidiano, e a instância da memória passa a nortear as reflexões históricas; o fato de a história oral ser praticada por diferentes grupos interessados em fazer o registro de sua história; e a centralidade da narrativa como forma e organização do discurso.

O processo teve um momento marcante, com a declaração, pela Oral History Association (norte-americana), de que a história oral "foi instituída em 1948 como moderna técnica de documentação histórica” (Thompson, 1998). Observamos, assim, no século XX, grande crescimento desse aporte na Europa Ocidental e na América Latina, recebendo importante contribuição da sociologia, por meio de Ferrarotti e dos estudos sociológicos da classe operária. 


\section{Na antropologia e na sociologia}

Os autores estudados apontam a grande contribuição da sociologia e da antropologia, no que se refere ao uso das histórias de vida como metodologia de pesquisa. Os antropólogos foram os primeiros a trabalhar com essa abordagem, dando a ela um estatuto de cientificidade (Muñoz, 1992, p. 15).

$\mathrm{Na}$ antropologia, foi a Escola de Cultura e Personalidade que enfatizou a utilização do método biográfico. Muñoz sintentiza um conjunto de obras que se desenvolveram a partir da referida escola e indica a importância da década de 1940 para o futuro desenvolvimento da abordagem. Destacam-se como características essenciais do uso dessa metodologia no campo antropológico, especialmente, as possibilidades de retratar a cultura, testemunhar o impacto das mudanças sociais sobre os indivíduos, mostrar determinadas dimensões de uma cultura, ilustrar aspectos teóricos e comunicar dimensões ocultas nos processos cognitivos (Muñoz, 1992, pp. 23-4).

A década de 1960 é também citada pela riqueza dos estudos produzidos, especialmente em sua fundamentação metodológica. Muñoz (1992) ressalta o trabalho de Lewis, colocado como ponto de referência mais importante do gênero biográfico dentro da antropologia social. Seu trabalho, que foi dedicado basicamente à recompilação de histórias de vida, teve grande expressão nas ciências sociais e como sucesso editorial. Ele utiliza relatos de vida cruzados e, em "Los hijos de Sánchez", retrata, por meio de uma estrutura polifônica, a narração, em paralelo, de cinco membros de um grupo familiar.

$\mathrm{Na}$ sociologia, a abordagem representativa e fundacional é, reconhecidamente, a Escola de Chicago (1920-1935). Entre as duas grandes guerras do século XX, o aporte biográfico se coloca no contexto de uma "sociologia militante", nos Estados Unidos e na Polônia. Encontramos, nesse momento, uma grande euforia quanto ao uso da metodologia biográfica (Pineau e Michèle, 1983, p. 137; Balandier, 1990, p. 7).

Chicago, nos anos 1920, tornou-se a capital do crime organizado, e o Departamento de Sociologia procurou constituir uma análise desse processo. O aporte biográfico possibilitou conhecer a situação e agir sobre ela no sentido da conscientização dos sujeitos (Pineau e Michèle, 1983, pp. 139, 142). Utilizando a biografia como método de observação participante, a enquete direta e tendo como inspiração trabalhos antropológicos, a Escola de Chica- 
go se coloca como grande marco dessa perspectiva, por meio do trabalho de William I. Thomas e Florian Znaniecki, que a promoveram.

Com a chegada de muitos emigrantes aos Estados Unidos, percebeu-se a importância de ter o registro de suas histórias, e Thomas e Znaniecki empreenderam uma vasta pesquisa nas famílias polonesas, constituindo um trabalho extenso de dois volumes. ${ }^{9}$ Thompson analisa com entusiasmo as práticas da Escola de Chicago:

Naqueles primeiros anos, os sociólogos de Chicago foram notavelmente inventivos em seus métodos, fazendo uso da entrevista direta, da observação participante, da pesquisa documental, do mapeamento e da estatística. Desenvolveram interesse especial pelo método de história de vida para o estudo de dois aspectos dos problemas sociais urbanos (Thompson, 1998, p. 85).

Florian Znaniecki instituiu, na Polônia, uma utilização significativa e original do método biográfico para recolha de informações e conscientização - uma consciência de classe e de consciência nacional. A utilização do método deu-se por meio de concursos públicos sistemáticos, convocados pelo rádio, com o objetivo de viabilizar a recolha de memórias escritas sobre determinados temas. Houve, assim, no período entre guerras, grande estímulo à produção de autobiografias escritas na Polônia, o que possibilitou a efervescência de uma verdadeira "memorialística popular", espaço de expressão sobre a sociedade em suas experiências individuais e coletivas (Pineau e Michèle, 1983, p. 142; Thompson, 1988, p. 87; e Muñoz, 1992, p. 37).

Destaca-se também a escola marxista do Instituto Social de Varsóvia, que assume uma dimensão militante em sua atuação de pesquisa. A autobiografia é trabalhada nesse instituto como uma forma de mobilização popular,

9 O trabalho contou com grande número de cartas trocadas entre membros das famílias polonesas emigradas para os Estados Unidos e com a longa autobiografia de um jovem. A nota introdutória do primeiro volume define a organização do grupo primário com o qual os autores trabalham e as longas colocaçóes introdutórias, e o final do segundo volume traz a dinâmica familiar, no aspecto da "desorganização social da família e da comunidade". A Escola de Chicago trouxe uma contribuição para a prática da criminologia, por meio das histórias de vida de jovens dos bairros pobres da cidade e de narrativas de presos, visando ao tratamento desses jovens. Outra dinâmica dessa escola foi o trabalho com idosos, que eram incentivados a escrever suas autobiografias, seus diários, a emprestar suas cartas ou a conceder entrevistas sobre suas histórias de vida (Ferrarotti, 1990, p. 165). 
articulada à análise das condiçôes objetivas por meio de documentários estatísticos. Esse é o sentido militante da utilização do aporte biográfico no início do século XX - pesquisador e entrevistado assumem papel ativo no processo de construção do conhecimento.

São muitas as diferenças entre essa utilização inicial do método e as abordagens contemporâneas, porém, Poirier et al. (1999, p. 11) afirmam um elemento significativo do método que é comum - a preocupação em "conservar documentos ameaçados de desaparecimento, registrar a escuta das últimas testemunhas", dar voz àqueles que não foram contemplados pela história oficial.

Após a II Guerra Mundial, os autores estudados identificam um “eclipse”, uma estagnação no emprego dos métodos biográficos e grande ênfase na abordagem quantitativa, nos tratamentos numéricos e nas formalizaçōes. Segundo Poirier et al. (1999, p. 11), depois da grande ênfase nas "life histories" nos Estados Unidos, observa-se um desapego por essa abordagem. Buscou-se inserir o método biográfico nas ciências da natureza, afirmando características como a objetividade, a pesquisa indutiva, nomotética e o trabalho com dados quantitativos, estatísticos e a tentativa de colocação da biografia no quadro epistemológico da sociologia tradicional. Somente nos anos 1950, contemplamos o retorno de estudos biográficos na Europa.

Balandier (1990, p. 9), no prefácio da obra Histoire et histoires de vie: la méthode biographique dans les sciences sociales, de Ferrarotti, afirma que o sociólogo forneceu grande impulso para a retomada desse aporte metodológico, pois criticou a utilização do método como ilustração, meio de se verificar determinada interpretação. Ferrarotti teceu uma interessante crítica à utilização fragmentária das histórias de vida pelas ciências sociais, ou seja, o recorte de informações biográficas para confirmação de fatos, apenas como fonte de informação pontual, ou, ainda, a redução da biografia a um exemplo, como ilustração de uma interpretação. Nesse caminho, perde-se o sentido do valor heurístico do método, reenviando-o ao quadro teórico lógico-formal, contrariando-se sua proposta epistemológica. Para Ferrarotti, o desafio do método biográfico é justamente trabalhá-lo a partir de sua epistemologia imanente, que se traduz pela dimensão subjetiva e pela exigência antinomotética (Ferrarotti, 1990).

A própria dinâmica do trabalho com o aporte biográfico, exigindo uma interação direta, uma relação pessoal incontornável entre o pesquisador e o 
entrevistado, foi colocando, a partir dos desdobramentos metodológicos, o referido aporte no contexto da pesquisa-participação, como participação humana significativa e meio de autodesenvolvimento. Nos anos 1960 e 1970, a literatura apontou um "reflorescimento multiforme" das histórias de vida, não só como metodologia, mas também em suas bases epistemológicas. Além do florescimento acadêmico, Pineau destaca que, na América do Sul, o método também reapareceu em sua dimensão de conscientização popular e, nos Estados Unidos, como estratégia de recolha de dados com grupos, não mais a partir de indivíduos isolados, através de questionários (Pineau e Michèle, 1983, pp. 148-9).

Em outra direção, encontramos na Europa o desenvolvimento das histórias de vida em uma perspectiva marxista, ${ }^{10}$ buscando para esse aporte outro estatuto epistemológico, "a biografia torna-se a ciência da produção do homem concreto”. Nos anos 1960, Jean Paul Sartre efetua uma crítica ao positivismo e ao marxismo, já que estes não deixam espaço para o estudo do homem em sua existência concreta, cotidiana; o sujeito fica apagado tanto em uma ciência geral quanto diante da história e dos movimentos de classe. Propõe, então, a possibilidade de estudar o homem na "totalidade sintética de suas significações”, buscando um método para atuar nessa complexidade. Para esse estudo do homem concreto, em suas múltiplas mediações sociais, Sartre toma como referência a dialética da praxis humana. Segundo Pineau, a perspectiva epistemológica dialética é a que parece dar conta, com mais propriedade, da especificidade do método biográfico (Pineau e Michèle, 1983, pp. 156-9).

Nesse contexto, destaca-se também Bertaux, que, nos anos 1970 e 1980, articula o aporte biográfico ao estatístico. Essa perspectiva pode ser observada em diversos momentos de sua obra Les récits de vie (1997). Há uma

\footnotetext{
${ }^{10}$ Sève, tendo como referência também a abordagem marxista, procura analisar o aporte biográfico com base na psicanálise, formulando uma teoria da personalidade. Segundo esse autor, os atos dos indivíduos constituem o resultado de um processo dialético entre uma dinâmica individual e coletiva, expressão de si e das relações sociais objetivas. $\mathrm{Na}$ mesma tradição militante das histórias de vida, destaca-se a abordagem de Catani, que procura dar voz àqueles que socialmente foram excluídos da palavra. Nesse sentido, ele distingue autobiografia, história de vida e história de vida social. Segundo esse autor, a autobiografia está ligada à tradição literária e focaliza os notáveis; a história de vida vem marcada por uma tradição institucional e clínica; e a história de vida social é resultado de uma relação dialética, um fazer de relação (Pineau e Michèle, 1983, pp. 160, 162, 171-2).
} 
busca por conciliar a necessária articulação entre a "estética literária" e a "ética humanista" das histórias de vida com o que considera perspectiva da investigação científica: a visão "cognitiva e objetivista". Bertaux sustenta como hipótese central que o "mesocosmo", ou seja, os movimentos que atuam sobre o conjunto do mundo social, são os mesmos que atuam sobre o "microcosmo", os indivíduos. Nesse sentido, o objetivo do trabalho com as narrativas de vida, para ele, é dar inteligibilidade aos processos sociais, confirmando uma abordagem "estruturalista-positivista" (Bertaux, 1997, pp. 6, 14).

Assim, no sentido de investigar o que há de geral nas situações particulares da vida, o autor propóe que sejam estudados muitos casos, a fim de estabelecer uma comparação. Há uma preocupação com a generalização dos resultados, a busca de um "modelo" que apresente validade do ponto de vista da análise global dos processos sociais. Muñoz (1992, p. 55) denomina essa perspectiva de Bertaux de "método de saturação informativa": o processo de saturação é o que garante a validade científica na observação de regularidades empíricas e o estabelecimento de perspectivas estruturais.

Logo, observamos que, na antropologia e na sociologia, as histórias de vida já contam com um longo caminho percorrido, marcado por momentos de grande ênfase nessa perspectiva metodológica, mas também por momentos de estagnação e de reflorescimento. São também muitos os autores que trouxeram contribuições significativas. Considerando a pluralidade nesse campo metodológico, Finger (apud Araújo e Magalhães, 2000, p. 19) sistematizou quatro abordagens, destacando a história oral, a Escola de Chicago, a "sociologie du cours de vie" de Bertaux e as contribuiçôes de Ferrarotti, considerando, de forma consensual, a produção de Ferrarotti como o grande marco no aporte (auto)biográfico. No próximo item, buscaremos sistematizar as principais contribuições e os mais importantes conceitos apresentados nos diferentes campos do conhecimento.

\section{Definiçóes e interfaces}

A passagem pela abordagem das histórias de vida, em diferentes campos das ciências humanas, faz-nos perceber uma multiplicidade de fios, de matizes que, embora diferenciados, trazem uma interessante interligação de pontos comuns. O olhar sobre esses fios e pontos varia, certamente, a partir da referência epistemológica do investigador, pois, como nos mostrou o per- 
curso histórico, as histórias de vida podem estar a serviço de diferentes perspectivas de construção do conhecimento. Considerando o foco teórico deste estudo, buscaremos articular as contribuiçōes da história às da sociologia, no que elas trazem de definições e interfaces entre esses campos, tendo como referência a dialética histórica que nos orienta o olhar.

A história de vida manifesta-se como movimento propriamente humano de dar sentido à vida e à sua historicidade. Constitui um enfoque teórico-metodológico que, rompendo com o paradigma lógico-formal, focaliza a vida, em suas tramas individuais e coletivas, como um lócus privilegiado de compreensão dos processos sociais e históricos. Nesse sentido, não se reduz a uma técnica de recolha de dados ou de informações, mas também não se afirma como uma teoria ou ciência isolada, colocando-se, por sua natureza, na mediação entre a prática da investigação e a construção de conhecimentos, em uma abordagem multirreferencial que vai possibilitando a inteligibilidade dos processos humanos.

A temporalidade assume grande relevância nessa abordagem, pois trabalhar com as histórias de vida aponta o desafio de ruptura com a linearidade paralisante do paradigma simplificador e nos coloca na intensidade de reflexões que cruzam passado, presente e futuro. $\mathrm{O}$ presente problematiza o passado, projetando o futuro. Assim, falar de história de vida, tanto na história como na sociologia, é falar do movimento ontológico de conhecer, de dar sentido às trajetórias vividas, desejando sempre a construção do futuro.

Encontramos também a ruptura com uma clássica colocação dos lugares de quem investiga e constrói conhecimento científico e de quem participa como objeto investigado. Investigadores e participantes são sujeitos do processo de conhecer e, nesse sentido, há um movimento de formação que envolve de forma vital aqueles que se colocam com a alma na pesquisa. As histórias de vida envolvem, portanto, a ação propositiva dos sujeitos, um trabalho laborioso de pavimentação do passado, na construção dos múltiplos sentidos do presente e do futuro. Segundo Thompson (1998, p. 43), "a história não deve apenas confortar; deve apresentar um desafio, e uma compreensão que ajude no sentido da mudança [...] O que se requer é uma história que leve à ação; não para confirmar, mas para mudar o mundo".

O olhar sobre as contribuições da história e da sociologia nos leva a essa tessitura comum. Os objetos de investigação peculiares a cada um desses campos vão sinalizando o caminho de suas especificidades. Todavia, situa- 
mos nosso trabalho na apropriação do fértil diálogo possível. Faz-se necessário, portanto, definir alguns conceitos e a forma como serão perspectivados nesse diálogo.

\section{Alguns conceitos}

Munôz (1992, p. 13) assinala a pluralidade terminológica que envolve o uso do método biográfico, em função de diferentes tradições acadêmicas e nacionais. Essa pluralidade traz dificuldades na definição conceitual, e, por isso, o autor propõe uma sistematização com base no que considera um consenso nesse campo.

Biografia e autobiografia são os termos mais utilizados e vêm de uma matriz literária, gêneros utilizados desde a antiguidade clássica.

Des récits écrits par l'individu concerné lui-même (ce qui exclut les biographies), présentés comme directement référentiels (ce qui exclut les romans) et portant sur une vie entière ou sur l'essentiel d'une vie (ce qui exclut à la fois les souvenirs d'enfance, les récits détachés d'épisodes de la vie adulte et les journaux intimes) (Lejeune, 1986, apud Pineau e Le Grand, 1993, p. 31).

[...] a autobiografia é a narração retrospectiva em prosa que uma pessoa real faz da sua própria vida, quando põe a tônica na sua vida individual e, em particular, na história da sua personalidade (Lejeune, 2003, p. 37).

Essas definiçóes nos ajudam a demarcar aspectos importantes. A autobiografia é uma produção escrita do próprio sujeito sobre si e tem como referência sua trajetória existencial, enfocando a vida de forma ampla; ou seja, ela não aborda fragmentos, mas busca a expressão da totalidade ou o essencial da vida. Referindo-se às histórias de vida, Josso (2002a, p. 20) também defende que uma especificidade dessa abordagem é a busca de enfoque sobre a globalidade de vida, e não sobre determinados aspecto. ${ }^{11}$ Essa perspectiva também é assumida por Araújo e Magalhães, que definem a história de vida como "narrativa solicitada a uma pessoa por quem pretende recolher as suas memórias de experiências, percursos e as subjectividades, abrangendo o período da sua vida desde

${ }^{11}$ Segundo Josso, o trabalho com "fragmentos" (2002, p. 20) caracteriza a perspectiva de projetos temáticos. 
os primeiros tempos até o momento em que decorrem os encontros" (2000, p. 13), reforçando, dessa forma, o carácter global das histórias de vida.

A biografia traz a presença do outro que recolhe informações e registra uma trajetória de vida, também na busca de globalidade. Tanto a autobiografia como a biografia focalizam a história individual. Entretanto, em uma perspectiva dialética, compreende-se que o individual está posto num processo coletivo de constituição. Nesse sentido, a narrativa é sempre plural e deve buscar a intensidade das mediações sociais e contextuais que dão sentido à trajetória estudada.

Araújo e Magalhães analisam as complexas relações entre a história de vida escrita com a participação do/a investigador/a (biografia) e a autobiografia. Se há uma perspectiva metodológica nitidamente diferenciada, as fronteiras são porosas, pois "a margem de autonomia da pessoa biografada é grande e que lhe compete seleccionar os acontecimentos e dar relevo às experiências que pode ou quer transmitir" (2000, p. 13). A presença do/a investigador/a não deve bloquear a emergência da subjetividade do entrevistado. Nesse sentido, a história de vida assume os contornos de um intenso diálogo.

As reflexóes sobre os conceitos de autobiografia e biografia, a partir da matriz do campo literário, trazem, dessa forma, indícios importantes para a constituição do método (auto)biográfico no campo das ciências sociais, nomeadamente na educação e na formação de professores/as.

Retornando a Muñoz (1992), encontramos uma sistematização de conceitos no campo das ciências sociais para as quais se considera, como marco, a publicação da obra The polish peasant, de Thomas e Znaniecki, em 1920, em que se emprega o termo "life history" para

describir tanto la narrativa vital de una persona recogida por un investigador, como la versión final elaborada a partir de dicha narrativa, más el conjunto de registros documentales y entrevistas a personas del entorno social del sujeto biografiado, que permiten completar y validar el texto biográfico inicial (Munôz, 1992, p. 13).

O termo "life story" foi introduzido posteriormente para referir-se à "narración biográfica de un sujeto que, a veces, puede ser publicada sin retocar, con fines de proporcionar una mayor fuerza testimonial, conservando incluso las propias peculiaridades lingüísticas de la persona” (Munõz, 1992, p. 13). 
A partir desses conceitos, percebe-se que o termo "life story" ("récit de vie", em francês) corresponde à "história de uma vida” tal como contada pelo próprio sujeito; já a "life history" ("histoire de vie", em francês) compreende o trabalho do investigador sobre a história contada pelo sujeito, bem como a introdução de outros documentos complementares (Munôz, 1992, p. 13).

Segundo Bertaux, o termo "récit de vie" foi introduzido na França mais recentemente e indica uma narrativa que resulta de uma entrevista, na qual o pesquisador solicita que o entrevistado narre toda ou parte de suas experiências de vida:

La conception que nous proposons consiste à considérer qu'il y a du récit de vie dès lors qu'un sujet raconte à une personne, chercheur ou pas, un épisode quelconque de son expérience vécue. Le verbe 'raconter' (faire le récit de) est ici essentiel: il signifie que la production discursive du sujet a pris la forme narrative (1997, p. 32).

O autor sublinha a diferença ente autobiografia e narrativa de vida: a primeira é um trabalho do sujeito feito a partir de uma narrativa escrita e autorreflexiva, priorizando um olhar sobre a globalidade da vida; a segunda assume a forma oral e é fundada no diálogo entre o investigador e o sujeito, focalizando as experiências por meio de um "filtro" (Bertaux, 1997, p. 34). O conceito de "filtro" é interessante no sentido de indicar que efetivamente a narrativa de vida prioriza o trabalho com os fragmentos da vida, que são orientados em função do objeto de estudo em foco e dos movimentos da memória daquele que reconta sua vida.

Bertaux busca estabelecer uma diferença entre a "história real de uma vida e a narrativa que é feita em circunstâncias dadas". Coloca-se contra uma abordagem "textualista", que vê a história de uma pessoa como uma realidade discursiva, afirmando a defesa de uma visão "realista", para a qual a história de uma pessoa parte de uma realidade que é condição prévia à forma como conta essa história. Afirma, assim, que, partindo de vários testemunhos, pode-se chegar à realidade do contexto sociológico, independentemente das singularidades (1997, pp. 32-3).

Esse autor destaca três funções das "narrativas de vida" (1997, p. 46) no contexto da investigação: a função exploratória, quando o pesquisador não tem familiaridade com o tema, e as narrativas constituem uma etapa inicial 
de recolha de dados; a função analítica, que constitui o processo de recolha e análise das entrevistas e de outras fontes; e a função expressiva, quando ocorre a publicação integral da narrativa, destacando-se a função de comunicação.

A preocupação com a ênfase no contexto e com a validação do trabalho biográfico engendrou uma perspectiva etnobiográfica, na qual a biografia constitui apenas uma das etapas do processo de investigação, sendo complementada por um conjunto de outros procedimentos. "O narrador não é um sujeito isolado, faz parte de vários grupos, de uma sociedade e de uma cultura precisas. É preciso que todas essas dimensões sejam restituídas" (Poirier et al., 1999, p. 38).

Poirier et al. (1999, pp. 38-41) analisam a etonobiografia como uma modalidade de trabalho no campo metodológico, afirmando que seu ponto de partida consiste na perspectiva de que as histórias de vida não constituem um produto acabado, mas o ponto de partida de um conjunto de outros procedimentos metodológicos que vêm no sentido de complementar a investigação. $\mathrm{O}$ narrador faz parte de vários grupos, de uma sociedade, de uma cultura; a etnobiografia procura reconstituir essas mediaçóes. Busca, desse modo, uma perspectiva global que envolve uma história de vida: contextualizada do ponto de vista sociocultural; analisada criticamente pelo narrador; colocada em debate pelos membros do grupo; e "confirmada pelos procedimentos clássicos do inquérito etnográfico", ou seja, pela realização de outras técnicas de investigação que viriam complementar a pesquisa. Muñoz destaca o conceito de "biograma" de Abel (1947, apud Muñoz, 1992, p. 14), "que es usado com bastante frecuencia para referirse a los registros biográficos de carácter más sucinto y que suponen la recopilación de una amplia muestra de biografías personales, a efectos comparativos [...]". Junto a essas narrativas, o investigador utiliza um conjunto de documentos pessoais e informaçôes que complementam o relato de vida.

Retomando a sistematização efetuada neste item, observamos uma pluralidade de expressóes e ênfases que indicam a polifonia e a riqueza de possibilidades metodológicas do enfoque que, tomando sua origem fundacional na antiguidade, talvez possa ser chamado, de forma mais genérica, de (auto) biográfico. Encontramos, nomeadamente, as expressóes história de vida, narrativa de vida, etnobiografia e história oral. Observamos, em cada uma delas, o foco em diferentes campos do conhecimento, sendo as três primeiras mais comuns no âmbito sociológico e a última referida mais especificamente ao 
campo historiográfico. Notamos também, na variação das expressōes, ênfases diferenciadas no processo metodológico de desenvolvimento das abordagens de investigação: na história de vida, percebemos foco na temporalidade; na narrativa de vida, ênfase na expressividade, na necessidade de visibilidade, de comunicação da vida no processo de investigação, por meio do trabalho com relatos orais e/ou escritos; na etnobiografia, o olhar dirige-se para as múltiplas formas de apreender o contexto estudado; e, na história oral, o foco centra-se essencialmente no depoimento oral como fonte da investigação histórica.

$\mathrm{Na}$ presente investigação, tomamos como referência o termo história de vida, pela articulação proposta entre vida e historicidade. O foco recai, então, na temporalidade como dimensão fundamental dessa abordagem, abrindo a possibilidade de trabalho com diferentes recursos, como narrativas orais e escritas, documentos pessoais, enfim, o que possa constituir apoio material e simbólico à expressão e à busca de sentido para a vida nas tramas do tempo. A expressão da vida como movimento ontológico traz necessariamente sua dimensão histórica manifesta num caminho de construção não previsível.

$\mathrm{Na}$ análise de diferentes modalidades de histórias de vida, Pineau e Le Grand destacam categorias que podem favorecer nossa análise: as mídias, os atores/autores, o objeto a exprimir - a vida -, os objetivos a seguir e a temporalidade (1993, p. 34). As histórias de vida são construídas tendo um suporte do ponto de vista material, passando, inicialmente, pelas narrativas orais, pela escrita e, na contemporaneidade, pela profusão de recursos tecnológicos que se afirmam como memória externa. As histórias de vida contam sempre com seus atores, os que trazem a vida para a narrativa, e aqueles que se colocam como autores, que podem ser os próprios sujeitos, no caso da autobiografia, ou sujeitos externos que fazem o registro pelos atores, no caso das biografias. O objeto a exprimir é a própria vida, em suas tramas e caminhos; os objetivos a perseguir são diferenciados, de acordo com os atores e autores; e o recurso da temporalidade se apresenta a partir de diferentes concepçóes sobre o tempo e sua dinâmica. O tempo pode ser visto como linear, estático e cronológico, com um olhar preso ao passado, ou não linear, trazendo a densidade de mediações do presente.

As histórias de vida, tanto no campo histórico como sociológico, assumem múltiplos desdobramentos conceituais, constituindo formas metodológicas também diferenciadas, algumas das quais apresentaremos, em forma de síntese, no item a seguir. 


\section{Diversidade metodológica ${ }^{12}$}

Para situar a diversidade metodológica, encontramos em Pineau e Le Grand (1993) uma interessante possibilidade de sistematização. Inspirando-se em Maurice Catani, os autores destacam algumas vertentes de trabalho com as histórias de vida: instrução biográfica - inquérito por meio de questionário; narrativa de práticas - focaliza um aspecto relativo a uma prática social da vida de um grupo de pessoas; entrevista biográfica - trabalho sobre uma ampla dimensão da vida, enfocando diferentes fases, em que a narrativa do entrevistado é reorganizada pelo investigador; história da vida social aprofundada - conjunto de entrevistas, nas quais o investigador estabelece uma relação profunda com o entrevistado, que participa de forma intensa de todas as etapas do trabalho; autobiografia - escrita da totalidade ou da parte da trajetória de vida pela própria pessoa; e história de vida de grupo - biografias cruzadas em que os sujeitos são associados, em diferentes intensidades, à pesquisa (ainda nessa categoria, coloca-se o trabalho com um grupo de formação no qual os participantes narram suas histórias na presença dos outros, resultando numa narrativa escrita individual ou colectiva) (Pineau e Le Grand, 1993, p. 112).

Muñoz (1992, pp. 49-55) indica a possibilidade de trabalho com o "caso único", visando aprofundar o estudo de determinado tema, ou de "relatos biográficos múltiplos" (relatos paralelos ou cruzados). Aqui é importante fazer referência às relações entre a abordagem (auto)biográfica e a perspectiva do estudo de caso. Segundo Sarmento, ainda que o estudo de caso apresente sua origem em estudos qualitativos e etnográficos ligados à escola antropológica de Chicago, observamos uma grande plasticidade sendo utilizada por diferentes matrizes teóricas e metodológicas:

O estudo de caso pode definir-se como 'o exame de um fenómeno específico, tal como um programa, um acontecimento, uma pessoa, um processo, uma instituição, ou um grupo social' (Merriam, 1998, p. 9); ou, então, como 'uma investigação empírica que investiga um fenómeno contemporâneo dentro do seu contexto real de vida, especialmente quando as fronteiras entre fenómeno e o contexto não são absolutamente evidentes' (YIN, 1994, p. 13) (2003, p. 137).

\footnotetext{
${ }^{12}$ A diversidade metodológica será sistematizada e apresentada nos quadros 1 e 2 do capítulo 3 .
} 
Nesses conceitos, destaca-se como aspecto comum a "natureza singular do objecto de incidência da investigação", situando-se em uma "unidade" ou "sistema integrado" (Sarmento, 2003, p. 137). Com base nessa reflexão, podemos questionar se os estudos biográficos são estudos de caso. Entendemos que nem todo estudo de caso tem natureza (auto)biográfica, mas toda pesquisa (auto)biográfica consiste em estudo de caso, pela particularidade e singularidade de trajetórias, podendo incluir as mais variadas modalidades, desde o estudo de caso único até os estudos de casos múltiplos.

No contexto específico das histórias de vida em grupo e focalizando a pesquisa-formação, Josso (2002a, pp. 15-20) sinaliza o desdobramento de duas vertentes: as histórias de vida como busca da compreensão biográfica da formação, por meio de um trabalho que coloca ênfase nos momentos da vida que se constituíram em efetivas experiências de formação, priorizando-se uma narrativa global da vida; e a colocação de abordagens biográficas no sentido do desenvolvimento de projetos específicos de formação, por meio de uma perspectiva experiencial e/ou tematizada. ${ }^{13}$

Encontramos, na síntese dos autores citados, uma variedade de possibilidades da investigação com o aporte das histórias de vida, um caminho metodológico que vai de uma perspectiva de trabalho com dados biográficos tratados de forma mais quantitativa, no caso das enquetes, ao tratamento mais qualitativo, no caso dos grupos de pesquisa-formação; de uma abordagem individual a uma abordagem coletiva; de uma narrativa direta - no caso da autobiografia, ou seja, sem a interferência do investigador - à presença do investigador como um dos sujeitos da pesquisa; da possibilidade de trabalho com a amplitude de diferentes fases da vida ao trabalho com fragmentos; de um controle direto do investigador, por meio de um questionário fechado, a uma atuação mais livre e tematizada pelos participantes.

É importante ainda incluir como possibilidade metodológica a contribuição dos "documentos pessoais". Além dos desdobramentos possíveis, como mencionamos, Plummer (1989, pp. 15-38) traz uma contribuição na sistematização de documentos que podem complementar e, em certos casos, constituir o recurso básico de uma pesquisa fundada no aporte (auto)biográ-

${ }^{13}$ Josso (2002a, p. 20) cita como exemplos de trabalho com projetos a construção de itinerários de experiências profissionais ou sociais e atividades que possibilitam a análise comparativa de saberes anteriores e competências que precisam ser adquiridas por adultos que, após longo tempo, retornam ao trabalho. 
fico. Há uma diversidade de documentos, e o autor observa diferentes usos dos mesmos nas ciências sociais, tendo como busca fundamental a subjetividade dos participantes. Dentre os documentos citados por ele, destacamos o diário, as cartas, a literatura baseada em fatos, as fotografias, os vídeos; enfim, são documentos que constituem a memória material dos sujeitos, que falam por meio de diferentes linguagens da vida e de seus movimentos.

A essa pluralidade metodológica, acrescenta-se a diversidade também na forma de tratamento dos dados e a dinâmica de sua interpretação. Poirier et al. (1999, p. 15) destacam investigações que realizam a reprodução integral das narrativas e outras que propõem sua reconstrução pelo investigador. Quanto à interpretação, Pineau e Le Grand (1993, p. 100) indicam três modelos: o biográfico - a interpretação é feita de forma prioritária pelo investigador; o autobiográfico - no outro extremo, coloca a interpretação na responsabilidade exclusiva do próprio narrador; e o dialógico - assentado na partilha, na qual narrador e investigador se colocam a responsabilidade sobre a análise e a interpretação.

Colocamo-nos, então, frente a uma ampla diversidade de caminhos trilhados pelas ciências humanas, encontrando diferenciações marcadas na concepção de pesquisa, no processo de seu desenvolvimento e na análise dos dados. Nesse sentido, compreendemos que as matrizes conceituais, o campo disciplinar ao qual está filiado o pesquisador e a problemática focalizada constituem elementos definidores do desdobramento metodológico e da perspectiva interpretativa adotada. No capítulo seguinte, focalizaremos o caminho dessa perspectiva teórico-metodológica no campo educativo e, especialmente, na formação de professores. 


\section{Capítulo 3 \\ Iniciando o diálogo: um olhar dirigido à literatura educacional}

Neste momento da pesquisa, olhamos a literatura educacional com a curiosidade de compreender as principais referências que marcam o campo de estudo proposto. Nesse movimento, recorremos especialmente a trabalhos realizados em Portugal, no Brasil e em países francófonos, dos anos 1980 aos dias atuais, ${ }^{1}$ buscando, assim, um diálogo entre a produção no referido domínio. A elaboração deu-se mediante uma lenta tessitura, que consistiu em garimpar periódicos, livros e outros trabalhos científicos, com o objetivo de encontrar os principais fios e matizes que pudessem oferecer uma visão sobre a temática em estudo.

Reflexões registradas no livro da vida sinalizam a intensidade do processo dessa tessitura:

As idas e voltas desse movimento levam-me a refletir sobre o sentido da revisão de literatura como caleidoscópio, e não como puzzle: se, no puzzle, as peças estão dadas e a atividade do sujeito centra-se na composição de uma imagem previamente definida, no caleidoscópio, a mudança dos movimentos encaminha diferentes encontros com fragmentos e pistas. É claro que, se há um sentido possível de interpretação da produção do campo das ciências da educação, em Portugal, no que se refere à relação entre histórias de vida e formação de professores, é certo também que esta é dada pelas possibilidades de encontro com diferentes 'pedrinhas', tal como no garimpo. A conjugação

Limitamos a pesquisa até o ano de 2006. 
dessas pedras vai indicando uma diversidade de possibilidades interpretativas (10 nov. 2005).

A informalidade da narrativa do livro da vida nos ajuda a situar o processo de constituição da revisão de literatura. Em movimentos de idas e voltas, fomos guiados por um caminho com categorias previamente definidas, mas também deixamos que o "encontro" com cada texto apontasse "vielas" inicialmente não visualizadas que se foram mostrando pertinentes ao estudo proposto.

Com base nessa análise, organizamos este capítulo, que se desdobra em três eixos. No primeiro, focalizamos, em uma contextualização geral, o olhar da literatura sobre os/as professores/as e a formação, especialmente elementos de conceituação da formação docente inseridos nos textos estudados. No segundo, dedicamo-nos à discussão central da pesquisa: "as histórias de vida e a formação de professores/as", em uma análise teórico-metodológica dos principais aspectos destacados. No terceiro, por fim, sinalizamos os cuidados e desafios que se colocam na utilização do aporte (auto)biográfico.

\section{O/A professor/a e a formação}

\section{Os/as professores/as, a formação e a pesquisa educacional}

Observamos na literatura educacional, de forma marcante, que o campo da formação de professores como um todo passa por uma "viragem" (Nóvoa, 1992a, p. 15), que se traduz pela recusa do modelo de racionalidade técnica e pela busca de um referencial que incorpore a subjetividade nos processos formativos. Enquanto a perspectiva da racionalidade técnica fragmenta o fazer pedagógico entre os que pensam e executam, lançando luz numa imagem docente como aquele que desenvolve propostas formuladas em outras instâncias, um conjunto de pesquisas, que se intensifica nos anos 1980, passa a olhar o/a professor/a como autor/a e gestor/a das práticas educativas e, portanto, como produtor/a de saberes pedagógicos e de uma identidade docente.

2 O texto "O/A professor/a e os espelhos da pesquisa educacional" consta na tese como um dos desdobramentos deste item e foi publicado como artigo na Revista Brasileira de Estudos Pedagógicos (Bragança, 2009, pp. 87-101). 
Nóvoa (1992a, p. 15) situa três olhares distintos dirigidos aos professores: na década de 1960, eram ignorados em seu potencial e autonomia; na de 1970, foram acusados de contribuir com a reprodução; na de 1980, controlados pela intensificação dos processos de avaliação. Contudo, localiza na década de 1980 um marco de viragem, com a publicação do livro $O$ professor é uma pessoa, de Ada Abraham, destacando a intensidade da produção acadêmica que se seguiu, focalizando a vida dos professores, os percursos profissionais, as biografias e autobiografias docentes, a ênfase no desenvolvimento dos professores, uma produção que teve o mérito de "recolocar os professores no centro dos debates educativos e das problemáticas de investigação".

Um olhar retrospectivo para a literatura nos leva a identificar as marcas dessa viragem. Em trabalhos de pesquisa anteriores, a revisão da literatura, no âmbito das produções brasileiras, reforça o processo de constituição de novas imagens sobre a docência, imagens gestadas em uma profunda articulação com o contexto histórico e social. É assim que, na década de 1960, encontramos a docência como "doação pessoal", "sacerdócio". "O professor/a professora deve ter características psicológicas que apontem o autodomínio, o controle emocional e a maturidade intelectual. Observamos uma tendência generalista que inclui arte, trabalho manual, cultura geral, ciência e os recursos tecnológicos”. Tratava-se de uma perspectiva marcada pelas contribuiçóes da psicologia na constituição do campo pedagógico (Bragança, 2001b, p. 9).

$\mathrm{Na}$ década de 1970, notamos um enfoque mecânico-tecnicista: por um lado, o professor era visto como executor; e, por outro, criticado como "reprodutor". No entanto, no final desse período, "as limitações vão sendo denunciadas, e a problemática educacional passa a ser analisada a partir de determinantes históricos e político-sociais que as condicionam". A década de 1980 foi um período caracterizado por um referencial teórico fundamentalmente materialista-dialético, que possibilitou a compreensão da profissão docente como construção histórica, marcada por mediações sociais, econômicas e culturais. A produção acadêmica busca olhar os/as professores/as como intelectuais orgânicos e a escola como mediação com a sociedade. Como principais problemas da formação docente, aponta "a ênfase atribuída à técnica, em detrimento da política, e a falta de articulação teoria-prática. Propõe, assim, a unidade orgânica desses elementos no processo de formação [...]”. Se, nesse momento, a literatura preponderante recai sobre as instituiçôes formadoras, por outro lado, observamos "uma 
concepção abrangente do processo formativo que se dá nos movimentos sociais e na própria prática pedagógica desenvolvida no cotidiano da escola” (Bragança, 1997, p. 441).

As publicações brasileiras dos anos 1990 continuaram um crescente movimento de olhar para o/a professor/a e sua formação, o qual se revelou nas muitas publicaçōes e reuniōes científicas que trouxeram a centralidade dessa temática. A construção do saber no cotidiano da escola, o professor como agente do ato pedagógico, sujeito que constrói conhecimento a partir da interação com seus pares, foram algumas das problemáticas focalizadas (Bueno, 1996; Torres, 1998; Bragança, 1997, 1998). Emergiu, assim, uma análise que procurava recuperar a subjetividade nos processos formativos; subjetividade como possibilidade de considerar que a produção dos saberes pedagógicos não tem um lócus específico e privilegiado nas universidades e centros de pesquisa, mas constitui um processo múltiplo, incluindo a voz dos/as professores/as, como sujeitos individuais e coletivos. A formação deixou de ser tratada como processo restrito aos espaços acadêmicos e passou a ser vista como um continuum que tem início muito antes da entrada na escola e se prolonga por toda a vida do educador; passou a ser encarada como um conceito amplo ligado à produção da vida do/a professor/a, da instituição escolar e da sociedade como um todo.

Verificamos, assim, um crescente movimento de foco sobre os/as professores/as, suas práticas e, especialmente, as inter-relações entre vida e docência. Bueno também ressalta a "notável ênfase que se tem posto sobre a pessoa do professor, aspecto este nitidamente ignorado, ou mesmo desprezado, nos períodos anteriores à década de 1980" (1997, p. 13). A mesma autora enfatiza a importância de aprofundar uma análise das abordagens que exploram a subjetividade do professor, especialmente o "método autobiográfico e os estudos com histórias de vida de professores", destacando a forma como estes vêm sendo trabalhados no campo educacional.

Pimenta relaciona a intensidade desse debate, a partir dos anos 1980, em países como Espanha e Portugal, ao processo de abertura após uma longa ditadura, assistindo-se ao reconhecimento da escola e dos/as professores/as como protagonistas desse processo. Houve uma ênfase na elevação da formação para o nível universitário, valorização de temas de pesquisa como "profissão e formação de professores" e "a valorização da escola e de seus profissionais nos processos de democratização da sociedade” (2002a, p. 11). 
No Brasil, recebemos grande influência dessa produção educacional, especialmente por meio do livro organizado por Nóvoa (1992b), Os professores e sua formação. Assistimos a um momento paradigmático com a centralidade do debate sobre os/as professores/as, "na valorização do seu pensar, do seu sentir, de suas crenças e seus valores como aspectos importantes para compreender o seu fazer" (Pimenta, 2002a, p. 13; Libâneo, 2002, p. 65).

Este livro situa-se nesse contexto paradigmático. Assim, é importante esquadrinhar os caminhos da referida produção acadêmica, perceber seus movimentos, suas tendências, formas de dizer a educação, os/as professores/ as e sua formação. Os discursos indicam marcas e referências epistemológicas, e o propósito de nossa reflexão é trazê-las a nós para percebermos os pontos de diálogo com a abordagem que buscamos em nossa pesquisa.

\section{Formação: a tessitura de uma colcha}

Do ponto de vista filosófico, pensar a formação traz o humano para o centro de nossa reflexão. Como sujeitos históricos, construímo-nos a partir das relaçóes que estabelecemos com nós mesmos, com o meio e os outros homens e mulheres, e é assim, nessa rede de interdependência, que o conhecimento é produzido e partilhado. As interações humanas vão constituindo a cultura, e a educação consiste na apropriação - recriação - desse conhecimento acumulado pela humanidade; e, nesse sentido, o processo educativo permeia toda vida humana.

As instituiçōes educativas se afirmam como espaços sociais em que esse movimento se dá de forma sistematizada. Contudo, o processo educativo não se restringe a elas; pelo contrário, perpassa toda a vida humana. Por meio da educação, o sujeito amplia sua visão de mundo e se organiza para atuar de forma crítica, propositiva e humana. O conhecimento é, portanto, uma possibilidade de libertação. A educação se coloca, dessa forma, como prática social, tanto em sua vertente institucionalizada como em sua vertente informal. Já a formação é um processo interior; liga-se à experiência pessoal do sujeito que se permite transformar pelo conhecimento. Logo, podemos afirmar que, potencialmente, todos os espaços e tempos da vida são espaços e tempos de formação, de transformação humana.

Observamos, entretanto, que a contemporaneidade nos confronta com uma intensa "aceleração" (Nora, 1993); convivemos com um ritmo 
tenso e intenso que leva, muitas vezes, à interdição da experiência, do diálogo, da partilha, do encontro, da reflexão e, nesse sentido, temos, hoje, mais a informação do que o conhecimento. Com Linhares (2000), perguntamos: quais são as possibilidades de pontes entre a vida e o conhecimento? O filósofo grego já dizia: "Conhece-te a ti mesmo e tu conhecerás o universo $e$ os deuses". O conhecimento como expressão da existência humana exige reflexão pessoal, exige parar a "aceleração" da vida cotidiana, o ritmo cronológico e se permitir voltar sobre si mesmo, fortalecendo os fios que, em cada ciclo de nossa vida, dão sentido à existência. Mas, ao mesmo tempo que, nesse movimento, reencontramos a nós mesmos, abrimo-nos ao outro, ao universo.

Nesse sentido, Josso (2002a, pp. 66-80) perspectiva a formação como busca vital, saber-viver, busca de si e do nós, da felicidade, do sentido e do conhecimento. Esses elementos indicam a perspectiva ontológica da formação que vem impregnada à natureza humana: é o estar no mundo, com as pessoas e a natureza, que vai abrindo caminhos para uma transformação interior e que, ao mesmo tempo, projeta-se nas relações do sujeito com o mundo, ou seja, há uma dialética indissociável entre o "eu" e o "nós" na constituição da formação.

Retomando os três mestres de Rousseau - eu, os outros e as coisas -, Pineau (1988) nos apresenta a teoria tripolar da formação humana, que envolve: auto, hétero e ecoformação. A autoformação é a dimensão pessoal de reencontro reflexivo em que as questóes do presente nos levam a problematizar o passado e a construir projeto sobre o futuro; a heteroformação aponta a significativa presença de muitos outros que atravessam nossa história de vida, pessoas com quem aprendemos e ensinamos; e a ecoformação fala de nossa relação com o mundo, o trabalho e a cultura.

Notamos que o conceito de autoformação aparece tanto no trabalho de Dominicé (1985) quanto no de Pineau e Michèle (1983) como o movimento em que o sujeito assume a responsabilidade por seu processo formativo, a "capacidade do indivíduo se autoeducar de maneira permanente", dentro de um contexto do homem como responsável e autônomo. Pineau utiliza a metáfora do "dia" e da "noite" para refletir sobre a autoformação: processo individual e subjetivo - noturno -, tendo como contraponto a heteroformação, processo institucionalizado e formal - diurno. "Notre culture s'est développée selon le régime diurne, régime du clair, du séparé, 
du distinct. Que la lumière disparaisse et cette culture s'évanouit. La nuit, les experts dorment, l'éducation aussi; les écoles sont fermées" (Pineau e Michèle, 1983, p. 17).

A noite vem como possibilidade de aflorar um espaço-tempo de energia, de contrapoder ao sentido da formação oficial, de autoformação, de desenvolvimento que se manifesta pela tomada da vida em mãos, num trabalho laborioso de dar sentido à existencialidade (Pineau e Michèle, 1983, pp. 15-22). Pineau e Michèle definem assim os processos de hétero e autoformação:

Ainsi le pôle hétéroformation se caractérise de façon pure par le pouvoir prépondérant d'un formateur 'responsable' qui impose les objets, objectifs et moyens de formation; le formé n'ayant qu'un rôle d'assimilation. Le pôle d'autoformation à l'autre extrémité représente la situation où le pouvoir est au sujet qui se forme selon des objectifs, objets et moyens non imposés par un autre; l'autre ou les autres n'étant présents que comme réalités influentes à accommoder (1983, p. 45).

Analisando o conceito de autoformação, Galvani (1995, pp. 97-100) identifica três aportes: o técnico-pedagógico, como aquisição individual de informaçōes, centrado na aprendizagem de saberes técnicos; o sociopedagógico, fundamentado em Dumazedier, por quem a autoformação é analisada como fato social, a mudança permanente da sociedade educativa impulsiona a formação pessoal; e o biocognitivo, que toma como referência as reflexões de Pineau, nas quais a autoformação é analisada como processo vital de interação cognitiva de todo vivente, e a formação, como processo ontológico vital de atualização de uma forma.

Encontramos na literatura estudada influência dos dois últimos aportes citados. Os trabalhos francófonos no campo da educação permanente tomam como referência uma perspectiva biocognitiva e existencialista para o processo de formação dos adultos, na qual a autoformação pressupõe uma experiência com o conhecimento, uma reorganização interna do sujeito frente à vida, a produção de sentidos e a transformação pessoal. Assim, a relação com o saber torna-se mais importante do que o próprio saber (Chené, 1988, p. 89). 


\section{Nas palavras de Couceiro,}

Formar-se é dar-se uma forma, o que significa, [...] 'pôr em conjunto elementos diversos que podem ser contraditórios’. Esta produção de unidade, de unificação, numa forma própria desenrola-se segundo uma dinâmica que reforça a singularidade pessoal, o que permite dar forma à totalidade de si mesmo e conduzir à produção de si próprio (1992, p. 56).

É preciso, contudo, ter cuidado com as apropriações do conceito de autoformação no sentido de responsabilizar, de forma enfática, o papel do sujeito individual sobre seu processo formativo. Se entendemos a formação como um processo interior, referido à possibilidade de o sujeito se permitir tocar pelos movimentos educativos da vida, transformando-os em experiências significativas, reconhecemos, então, o lugar central do sujeito. Afirmamos, no entanto, que a intensidade das experiências que se tornam significativas e formativas é necessariamente coletiva. Elas vêm de um investimento social, no caso do processo escolar, ou das tramas, dos encontros e desencontros que temos com os outros e com o meio, ao longo da vida. Atribuir ênfase à autoformação como processo individual acarreta o risco de fortalecer a posição ideológica de isolamento do sujeito, discurso articulado às propostas de educação no bojo do conceito de empregabilidade. ${ }^{3}$

Nóvoa contextualiza a apropriação do conceito de autoformação a serviço das políticas de emprego, afirmando:

A expressão lifelong learning servia melhor aos propósitos de uma ideologia da formação 'colada' às questôes do emprego. A partir de meados dos anos 1990, a 'educação e formação ao longo da vida' aparece como tema obrigatório da agenda política, nomeadamente na União Europeia. A sua definição, em paralelo com o novo objectivo da empregabilidade, permitia transferir para o plano individual a resolução da crise do chamado 'modelo social europeu'. A partir de então, Bruxelas escreve em todos os seus documentos que 'deve ser concedida prioridade à educação e formação ao longo da vida’ e que os

3 Dentro da lógica de uma economia política liberal, a autoformação se coloca como "paradigma do milênio futuro": considerando a impossibilidade de formar o indivíduo para as solicitações do futuro, atribui-se aos sujeitos a responsabilidade pela mudança do estado, das organizaçóes e dos profissionais da educação (Carré, 1995, pp. 8-9). 
cidadãos 'devem ser responsáveis por actualizar constantemente os seus conhecimentos e melhorar a sua empregabilidade' (2002, p. 9).

Sem minimizar a importância da participação e do envolvimento do sujeito em seu processo de formação permanente, demarcamos uma posição crítica quanto à abordagem que responsabiliza o sujeito por esse processo, esvaziando o significado e a importância de políticas públicas que garantam a qualidade do processo educativo formal e o acesso a ele. Buscamos, assim, o sentido da colocação do sujeito no processo de investigação; um sujeito, contudo, necessariamente imerso em relaçôes sociais que o constituem e dão sentido ao seu projeto de formação.

O conjunto das referidas discussōes conceituais, originárias do campo da formação de adultos, influenciou concepçóes e práticas de formação docente, especialmente referências e discussões que trazem a importância da autoformação, de uma abordagem experiencial/pessoal e o questionamento das concepções de formação inicial e contínua.

Segundo Santana (1993), o conceito de autoformação apresenta uma relação com o entendimento do desenvolvimento profissional dos professores, passando pela revalorização da experiência como processo formador, elemento fundamental de construção do conhecimento profissional.

Analisando referências de formação de professores, Estrela destaca perspectivas ancoradas em uma filosofia e em uma pedagogia essencialistas, "valorizadoras de uma concepção racionalista do homem e de uma visão normativa do ensino e da profissão, de uma imagem da profissão como trabalho intelectual de carácter técnico" (2002, p. 21) e modelos da pós-modernidade, que veem o professor como sujeito ativo de sua formação. Nesse âmbito, destaca também perspectivas centradas nos percursos, com base personalista ou desenvolvimentista, que valorizam a autonomia do professor no processo de construção do conhecimento e abordagens em que a escola é vista como uma comunidade aprendente e o centro de uma comunidade educativa.

Nesse sentido, Moita apresenta um trabalho de investigação realizado em Portugal que toma como pressuposto a formação não como atividade de aprendizagem situada no tempo e no espaço, mas como ação vital de construção de si próprio: "formar-se supõe troca, experiência, interacções sociais, aprendizagens, um sem fim de relações" (1992, p. 115). 
Partindo das contribuições de Josso, Souza analisa os conceitos de experiência formadora e aprendizagem experiencial como referências teóricas de um processo de investigação-formação em contexto de estágio supervisionado.

A organização e a construção da narrativa de si implicam colocar o sujeito em contato com suas experiências formadoras, as quais são perspectivadas a partir daquilo que cada um viveu e vive, das simbolizações e subjetivações construídas ao longo da vida. Por isso, "[...] para que uma experiência seja considerada formadora, é necessário falarmos sob o ângulo da aprendizagem [...]" (Josso, 2002, p. 34). Em tese, caberia entender os sentidos e significados que são vinculados ao processo de interiorização e exteriorização eleito por cada um para falar de si, das suas aprendizagens, dos valores construídos e internalizados em seus contextos social e histórico, dos comportamentos, posturas, atitudes, formas de sentir e viver que caracterizam subjetividades e identidades (Souza, 2008, p. 92).

Assim, a formação fala da experiência pessoal do sujeito, profundamente articulada aos contextos sociais e culturais mais amplos. A literatura que toma como referência a abordagem (auto)biográfica sinaliza concepções de formação que dialogam e se entrelaçam, concepções que se manifestam em diversos desdobramentos teórico-metodológicos para o campo educativo e a formação de professores.

Retornando ao diálogo inicialmente proposto entre os conceitos de educação e formação, encontramos, na verdade, significados em disputa, pois, se apresentamos e discutimos o sentido do segundo conceito como movimento interior de transformação, uma experiência com o conhecimento, uma reorganização interna do sujeito frente à vida, encontramos também, em outras abordagens téorico-metodológicas, a ênfase colocada sobre os processos.

Alguns autores identificam, na palavra formação, a complexidade de duas dinâmicas distintas, o que traz uma dificuldade de definição. Jobert (apud Dominicé et al., 2000a, p. 232) afirma a ambiguidade da palavra formação, que designa duas realidades: uma prática social de formação, em diferentes instituições, e o processo pelo qual o indivíduo se constitui. Josso (1988a, p. 37), nesse mesmo sentido, refere-se à dificuldade semântica como 
uma mesma palavra a indicar a atividade em seu desenvolvimento e o respectivo resultado.

Dessa forma, na literatura, deparamo-nos com duas possibilidades, em definições que se articulam: a educação como processo externo, prática social; e a formação como transformação pessoal do sujeito, ou a utilização da expressão formação abrigando ambos os sentidos, como movimento institucional e externo ao sujeito e como processo de transformação pessoal.

Dominicé destaca o sentido da educação como prática social relacionada a organizações e programas e tematiza a formação como processo dinâmico e pessoal que depende "da multiplicidade de interações que existem entre o ator individual ou coletivo e o ambiente educativo" (1985, p. 13). ${ }^{4}$ Nesse sentido, a formação "depende" da forma como o sujeito vive e transforma suas vivências em experiências.

As literaturas brasileira, portuguesa e francófona, que tomam como referência a abordagem (auto) biográfica, sinalizam concepções de formação que dialogam e se entrelaçam, concepções que se manifestam nos desdobramentos teórico-metodológicos no campo educativo e, nomeadamente, na perspectiva de formação de professores, como analisaremos no item que se segue.

\section{História de vida e formação de professores/as}

Mas as leituras que fiz hoje - pequenos textos, então, pude percorrer vários - possibilitaram-me encontrar narrativas de diferentes naturezas, vindas também de diferentes focos de investigação, mas que como narrativas me tocaram, me fizeram chorar, me levaram ao encontro de minhas próprias histórias - apesar do espaço vital tão marcadamente diferenciado: histórias passadas em Portugal, histórias vividas por mim no Brasil. A narrativa é mesmo uma fonte de encontro; encontro com o outro, com os outros, comigo mesma. Histórias de famílias de aldeias portuguesas e sua luta para manter os filhos na escola, alguns sucessos e fracassos, a história da 'pequena Alice' [...] (Benavente et al., 1991), genealogias de famílias, construídas por alunos do $6^{\circ}$ ano em um projeto de memória, envolvendo toda a comunidade escolar, histórias das famílias portuguesas em diferentes contextos, inclusive das imigraçōes para o Brasil, das dificuldades, do racionamento, da fome no período

4 Tradução livre da autora. 
de guerras (Araújo e Stoer, 1993) [...] As leituras foram descortinando relações potentes com a pesquisa em andamento (10 nov. 2005).

A revisão de literatura seguiu buscando, no caleidoscópio da pesquisa educacional, diversas possibilidades de imagens e composiçôes. Nesse movimento, fomos surpreendidos muitas vezes pela beleza dos textos e por indícios importantes para o estudo proposto. Buscamos, no presente item, sintetizar os indicativos da influência e da contribuição da abordagem (auto)biográfica, nomeadamente para a formação de professores/as. Trazemos, assim, um diálogo, destacando a presença dessa perspectiva teórico-metodológica no contexto epistemológico das ciências da educação, especialmente o aporte teórico, a diversidade metodológica, os campos de utilização e as contribuições indicadas pela literatura na relação com a formação docente. Frente à amplitude da literatura educacional, não temos a pretensão de encontrar uma totalidade, mas apenas indícios, pistas, sinais que ajudem a situar a contribuição da tematização da "vida" e do "tempo" em contextos de formação de professores/as.

\section{História de vida e educação}

A perspectiva de trabalho com as histórias de vida, no campo educativo, vem no ambiente do "retorno do sujeito", ou seja, após a hegemonia das concepções estruturalistas que predominaram até o final dos anos 1970. É na efervescência paradigmática, que trouxe a discussão do sujeito em sua singular complexidade social, que as pesquisas em educação foram sendo permeadas por um enfoque que procurou recuperar a reflexividade humana e filosófica dos processos de construção do conhecimento em educação.

Deparamo-nos, nas ciências humanas, com uma mudança paradigmática que reconduziu o olhar do geral ao particular, da totalidade ao fragmento, da quantidade à qualidade, do instituído ao instituinte. Tais movimentos não ficaram alheios às ciências da educação e, desde a década de 1980, têm contribuído para o desafio cotidiano de reinvenção das práticas educativas e de pesquisa. Foi nesse contexto que os métodos (auto)biográficos foram sendo colocados, especialmente no campo da formação (Nóvoa e Finger, 1988, p. 13). Ainda que sua utilização no campo educativo seja recente, compara- 
tivamente às ciências humanas, o olhar dirigido à literatura nos faz perceber sua crescente ampliação e seu aprofundamento teórico-metodológico.

Analisando o desenvolvimento dessa perspectiva no campo educativo, Nóvoa (2002, p. 9) destaca que foi no âmbito de discussão sobre a educação permanente que o aporte (auto)biográfico se colocou como possibilidade metodológica. A crítica à ênfase tanto no modelo escolar, como forma hegemônica do processo de formação, quanto na infância, como idade específica desse processo, encaminhou a discussão para a educação permanente, valorizando-se a educação ao longo da vida e a aprendizagem como movimento que envolve também a vida adulta. Nesse mesmo sentido, Pineau e Le Grand (1993, p. 18) afirmam que é na formação de adultos que a história da vida se desenvolve, desde os anos 1980, como perspectiva de pesquisa e prática de formação, buscando sempre uma articulação entre teoria e prática.

O número 142 da revista Education Permanente, publicado em 2000 com o título Les Histoires de Vie: Théories et Pratiques, retoma os números 72 e 73, de 1984, dedicados às histórias de vida, em um movimento de avaliação do desenvolvimento dessa perspectiva no âmbito dos estudos sobre a educação permanente. $\mathrm{O}$ objetivo é fazer um balanço, destacando a diversidade metodológica e questôes de ordem epistemológica de um enfoque que, embora, a princípio, tenha sido marginal, foi-se consolidando num crescente movimento de sustentação. ${ }^{5}$

Diversos autores destacam especificamente a publicação dos números 72 e 73 da referida revista como marco fundacional na afirmação e no desenvolvimento da articulação entre as histórias de vida e o campo da formação, citando ainda o colóquio realizado na Universidade de Tours em 1986. Gaulejac (Dominicé et al., 2000a, pp. 221-2) se refere a esse colóquio como um momento de afirmação do que denomina de "corrente das histórias de vida em formaçāo", pois diferentes pesquisadores que já trabalhavam nessa linha tiveram oportunidade de encontro. A partir de então, observa-se, segundo os autores, o desenvolvimento da fundamentação teórica e metodológica dessa perspectiva no campo educativo (Orofiamma et al., 2000, p. 7; Dominicé et al., 2000a, p. 217; Pineau, 1994, p. 24). Nesse caminho de afirmação, Pineau (2000a, p. 63) registra a

5 O número 142 abrange uma diversidade de trabalhos, indicando a pluralidade de enfoques que incluem o trabalho social, a orientação, o reconhecimento e a validação de aquisições, metodologias de balanço, desenvolvimento pessoal, metodologias terapêuticas, práticas de escrita e de teatro, histórias de coletividade e outros (Orofiamma et al., 2000, p. 7). 
criação, em 1996, do movimento L’Association Internationale des Histoires de Vie en Formation (ASIHVIF) e da coleção História de Vida e Formação como busca de diálogo no interior desse campo.

Refletindo sobre a especificidade fundadora da relação entre a abordagem (auto)biográfica e o campo educativo, Couceiro questiona a lógica de utilização que tem sido privilegiada: "Uma lógica mimética em relação ao seu uso noutras disciplinas? Uma nova e diferente perspectiva, tendo em conta um objecto específico e identificável, neste domínio? E neste caso, qual é então esse objecto específico?" (2002b, p. 156). E a autora encaminha a seguinte reflexão:

Assim sendo, podemos dizer que o objecto próprio das histórias de vida, em ciências da educação, é a formação/autoformação, na medida em que nos permitem conhecê-las melhor e os seus processos. De algum modo as histórias de Vida são uma 'mediação' para a formação. Não no sentido de as considerar como uma técnica de formação, mas como uma abordagem que produz, ela própria, um certo tipo de formação e um certo tipo de conhecimento. Ou seja, as histórias de vida influenciam a natureza da formação que se produz, introduzindo mesmo uma ruptura epistemológica no conceito de formação (p. 157).

Portanto, nas ciências da educação, a utilização da perspectiva teórico-metodológica das histórias de vida vem atrelada à formação, entendida como processo permanente ao longo da vida. Enquanto nas ciências humanas, a partir da origem sociológica, coloca-se como metodologia de pesquisa, em educação, centra-se nos processos formativos.

$\mathrm{Na}$ introdução de $\mathrm{O}$ método (auto)biográfico e a formação, Nóvoa e Finger destacam o objetivo de

dar a conhecer ao público português interessado pela problemática das ciências da educação e da formação de adultos um conjunto de reflexões em torno da utilização das histórias de vida (ou do método biográfico ou das biografias educativas ou [...]) como instrumento de investigação-formação (1988, p. 11).

Percebemos, assim, na interação entre práticas de pesquisa e formação, a afirmação dessa abordagem no campo educativo. Mesmo quando a perspectiva se coloca centrada na investigação, o fato de rememorar a vida traz para os/as participantes um sentido formador. 
A literatura estudada indica polos acadêmicos que desenvolveram essa abordagem: na Universidade de Genebra, com os pesquisadores Pierre Dominicé, Marie-Christine Josso e Mathias Finger, por meio do trabalho com o conceito de biografia educativa; e em Quebec, com Gaston Pineau, onde as histórias de vida colocaram-se como possibilidade de pesquisa-formação e de autoformação. Com um aporte específico no pragmatismo de John Dewey, nos Estados Unidos, Donald Schön trabalha conceitos ligados à reflexão sobre a prática profissional como caminho de construção do conhecimento, abordagem amplamente difundida nas pesquisas em educação (Pineau e Le Grand, 1993, p. 18; Nóvoa, 2002, p. 9; Josso, 2002a, p. 19).

Destacamos, nesse sentido, duas ênfases de investigação: a biografia educativa e a relação com o conceito de autoformação. Dominicé (2000, pp. 2-11), partindo de um trabalho sobre avaliação, encontrou na abordagem autobiográfica uma forma de estudar o processo de aprendizagem, por meio da análise do impacto da lembrança dos anos escolares. Nesse caminho, chegou ao trabalho com a "biografia educativa", no qual a história de vida focaliza o processo de aprendizagem do autor, e não apenas aspectos aleatórios da vida. Investindo nessa perspectiva, Dominicé afirma que as biografias educativas contribuem para melhorar a compreensão do processo de aprendizagem do adulto, possibilitando reorganizar as diversas influências sobre o processo de formação e as articulações entre os diversos movimentos da vida e a aprendizagem. Nesse sentido, a formação é compreendida como aliança entre a aprendizagem formal e a experiencial. Outro enfoque das histórias de vida em educação é a exploração de sua articulação com o conceito de autoformação, tal como analisamos anteriormente.

Tanto os recursos da biografia educativa, com os pesquisadores de Genebra, quanto o conceito de autoformação, trabalhado em Quebec, contribuíram para o desenvolvimento da abordagem (auto)biográfica que se foi manifestando em uma multiplicidade teórico-metodológica de trabalhos no âmbito educativo. Josso (2002a, pp. 11, 13) sinaliza especialmente a ênfase na formação de adultos, nos currículos para a formação de professores, no impacto sobre a formação contínua e em projetos diferenciados ligados à formação profissional. Pineau (Pineau e Michèle, 1983, p. 182) também analisa as diferentes utilizações das histórias de vida em educação de adultos, destacando a conscientização popular na América Latina, o trabalho com as histórias dos analfabetos em Quebec, a formação profissional contínua e a formação de formadores. 
O conjunto da produção que se desenvolveu manifestou grande influência sobre a investigação, destacando-se as possibilidades de articulação entre esta abordagem teórico-metodológica e o campo da formação de adultos de uma forma geral. Neste trabalho, focalizamos, nomeadamente, as relações estabelecidas com a formação de professores/as pela fertilização de uma diversidade de pesquisas e práticas.

\section{História de vida e formação de professores ${ }^{6}$}

No contexto da formação de professores, a abordagem das histórias de vida se coloca também no movimento de mudança paradigmática; um novo olhar sobre o/a professor/a e sua prática vai sendo tecido, indicando mudanças no campo da formação, da investigação e das práticas. Buscamos, aqui, um olhar para a literatura e a tessitura de um diálogo que possibilite situar os marcos fundacionais da articulação entre histórias de vida e formação de professores, bem como referências sobre o aporte teórico-metodológico que vem sendo utilizado.

\section{Um olhar dirigido à polifonia dos aportes teóricos}

A leitura de diversos textos, livros e trabalhos nos leva ao encontro de uma polifonia de aportes teóricos quanto aos campos disciplinares de referência, às linhas filosófico-pedagógicas e aos autores citados. É exatamente essa polifonia que constitui a marca teórico-metodológica das pesquisas e práticas que articulam história de vida e formação, tanto na abordagem geral da formação de adultos como especificamente na formação docente. Encontramos, nessa produção, a presença do diálogo interdisciplinar e uma abertura à literatura e à arte.

Os campos disciplinares mais citados como referências de filiação dos trabalhos desenvolvidos são a sociologia, a história, a antropologia, a psicologia e a filosofia, ou seja, as ciências humanas; entretanto, em vários trabalhos, especialmente dos países francófonos, encontramos indicações de autores e conceitos ligados à biologia. Algumas pesquisas tomam um campo como re-

6 Uma síntese deste item foi publicada no texto "Histórias de vida e formação de professores/as: um olhar dirigido à literatura educacional” (Bragança, 2008a). 
ferência, e o desenvolvimento da investigação direciona o olhar para contribuiçōes vindas de outras áreas ${ }^{7}$ e para trabalhos que, a princípio, buscam fundamentação em vários campos das ciências humanas. ${ }^{8}$ Autores como Catani et al. (1997), Pérez (2003b), Baudouin e Turkal (2000) e Dominicé et al. (2000b) reforçam a interdisciplinaridade como o caminho de trabalho com as histórias de vida, pois é no cruzamento de diferentes aportes que a metodologia e as possibilidades de análise e interpretação se colocam de forma mais rica. A natureza epistemológica das abordagens (auto)biográficas indica uma ruptura com as clássicas perspectivas disciplinares.

Quanto às linhas filosófico-pedagógicas, a perspectiva de trabalho com as histórias de vida, no campo da formação de professores, situa-se no movimento paradigmático de busca de uma nova epistemologia, de recondução do sujeito e da subjetividade como fundamentais ao olhar para a realidade social, educativa e para a escola e a docência. Desse modo, as linhas de referência mais citadas pela literatura são a fenomenologia, a hermenêutica, o neomarxismo, o existencialismo e o interacionismo simbólico, perspectivas que, em diferentes medidas e contextos, buscam a afirmação de um conhecimento mais "humano" no campo das ciências sociais, conhecimento este fundado na compreensão.

Ao encontrarmos uma diversidade de campos disciplinares, perspectivas filosóficas e autores citados, percebemos, nos estudos e pesquisas que trazem a centralidade das histórias de vida para o campo educativo, nomeadamente para a formação de professores, e, ainda, determinada perspectiva epistemológica, uma "unidade na diversidade". Em diferentes "medidas e intensidades", são trabalhos que buscam uma racionalidade instituinte, a possibilidade de afirmação da pesquisa e da formação com um olhar sobre o sujeito, em uma autoprodução de si mesmo, produção esta profunda e dialeticamente articulada às complexas dinâmicas da vida pessoal e coletiva. São trabalhos que rejeitam não só o determinismo das estruturas, mas também o isolamento dos sujeitos, que colocam o desafio de reinventar o fazer científico além de fronteiras disciplinares.

7 Podemos citar o trabalho de Araújo (2000), que, ligado ao campo da análise sociológica, trouxe grande contribuição para a história da educação e para o estudo da formação de professores.

8 Os trabalhos de pesquisa e formação desenvolvidos por Josso $(1994,2002)$ fazem referência a um amplo referencial teórico ligado a diferentes campos, como a filosofia, a sociologia, a psicologia, a biologia. Sarmento (2002), para estudar as Histórias de vida de educadoras de infância, busca também fundamentação teórica em diferentes campos do conhecimento, como a sociologia das profissóes, a teoria da formação de professores, a história da educação e o currículo. 


\section{A diversidade metodológica}

O olhar para a literatura também nos coloca frente a um amplo espectro metodológico. As histórias de vida, no campo educativo, desdobram-se e fertilizam práticas de formação e investigação. Buscamos, assim, a compreensão dos movimentos desse campo, de suas principais tendências e sinalizaçôes. Nóvoa ressalta a diversidade e as dificuldades de sistematização das abordagens (auto)biográficas voltadas ao estudo dos professores:

Esta diversidade dificulta a categorização dos estudos centrados nas histórias de vida dos professores. Cada estudo tem uma configuração própria, manifestando à sua maneira preocupações de investigação, de acção e de formação. É muito difícil separar analiticamente as distintas abordagens (auto)biográficas, na medida em que elas se caracterizam justamente por um esforço de globalização e de integração de diversas perspectivas (1992a, p. 20).

A natureza inter e transdisciplinar das histórias de vida possibilita, como sinalizado pelo autor, a integração de diversas perspectivas, apontando a grande riqueza e polifonia epistemológica e metodológica, mas também a dificuldade de sistematização de nossa análise sobre essa perspectiva.

Em um esforço de sistematização, Nóvoa (1992a) encontra grandes linhas, a partir dos objetivos e dimensóes que cada abordagem privilegia. Quanto aos objetivos, destaca trabalhos: (a) essencialmente teóricos, relacionados com a investigação; (b) essencialmente práticos, relacionados com a formação; e (c) essencialmente emancipatórios, relacionados com a investigação-formação. Quanto às dimensões, destaca o enfoque sobre: (a) a pessoa; (b) as práticas; e (c) a profissão. No capítulo 1, esboçamos uma sistematização que toma como referência trabalhos produzidos em diferentes áreas das ciências humanas centrados no aporte (auto)biográfico. Agora, organizamos a referida sistematização por meio de dois quadros, ${ }^{9}$ para que possamos visualizar, de forma mais objetiva, os desdobramentos metodológicos no campo específico da formação de professores.

9 Os quadros 1 e 2 foram publicados no texto "Histórias de vida e práticas de formação" (Bragança e Maurício, 2008). 


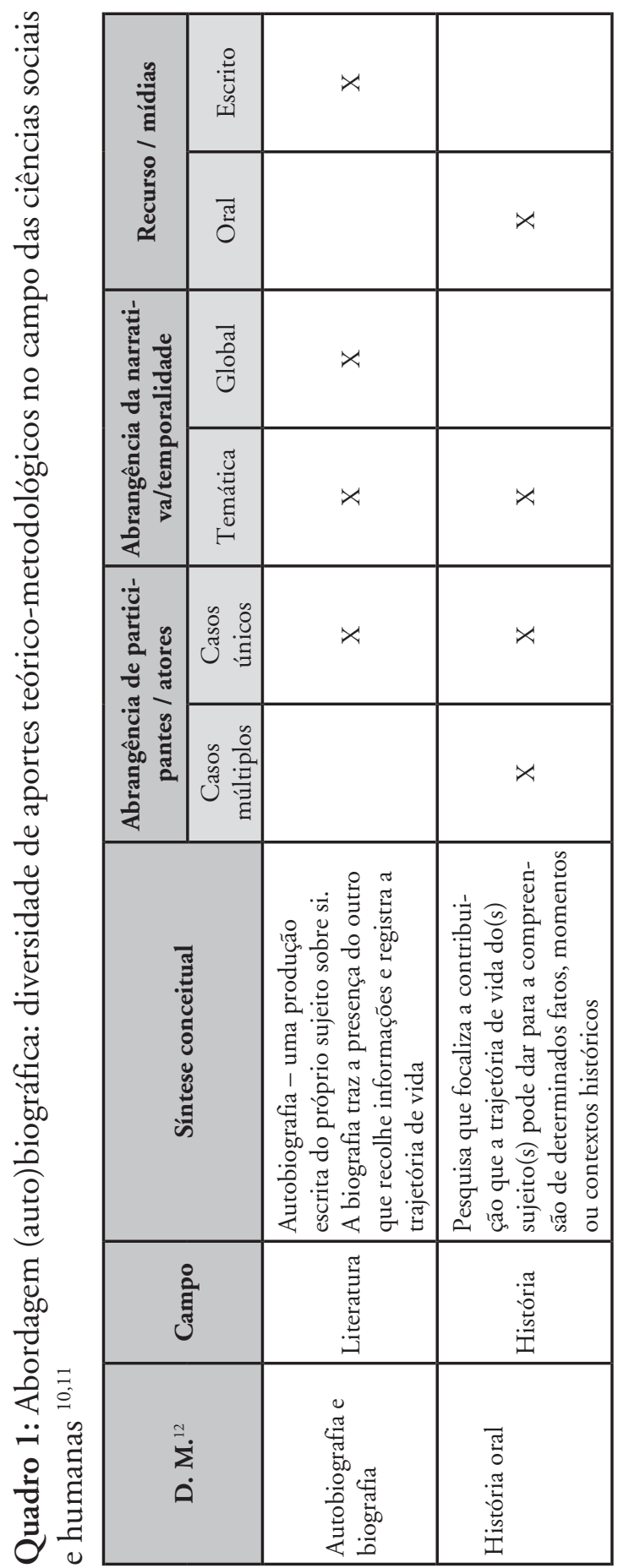

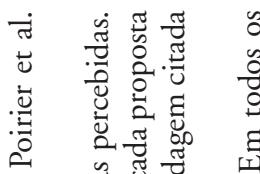

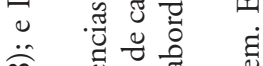

م)

.

ฉ

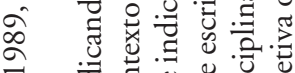

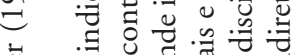

घี की

छ

․ 引

ปิ สิ

¿. $\stackrel{\sigma}{\Xi}$.

๗

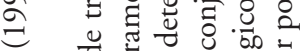

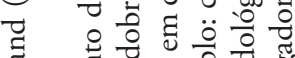

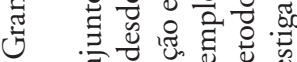

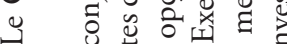

- 0 苛

च

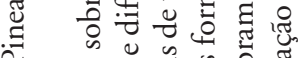

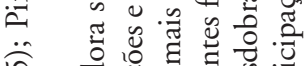

命

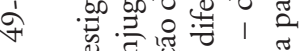

¿े

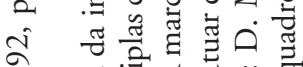

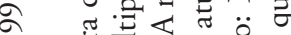

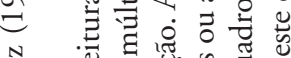

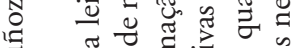

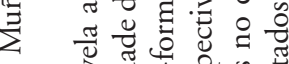

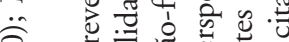

ิ

n

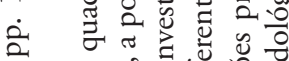

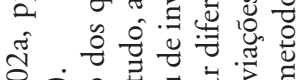

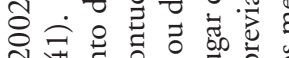

广ै

o

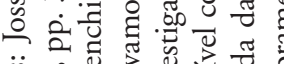

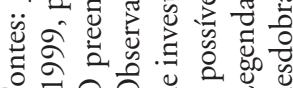

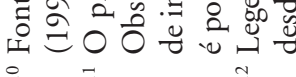




\begin{tabular}{|c|c|c|c|}
\hline$x$ & $x$ & $x$ & $x$ \\
\hline$x$ & $x$ & $x$ & $x$ \\
\hline$x$ & $x$ & & $x$ \\
\hline$x$ & $x$ & $x$ & $x$ \\
\hline$x$ & $x$ & $x$ & $x$ \\
\hline$x$ & $x$ & $x$ & $x$ \\
\hline 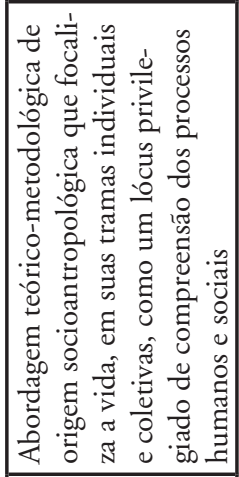 & 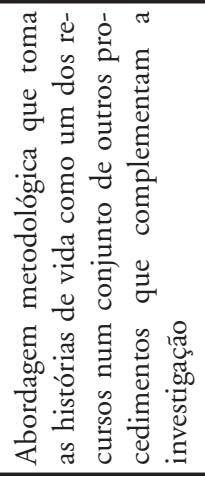 & 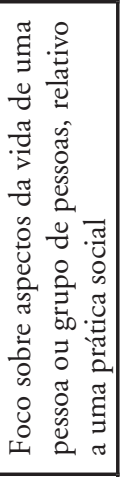 & 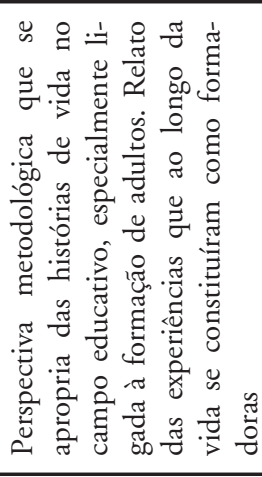 \\
\hline 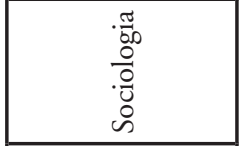 & $\begin{array}{l}\cdot \frac{\pi}{60} \\
0 \\
\frac{0}{0} \\
0 \\
0 \\
\infty\end{array}$ & $\begin{array}{l}\frac{1}{0} \\
\frac{0}{0} \\
0 \\
0\end{array}$ & 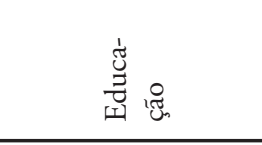 \\
\hline 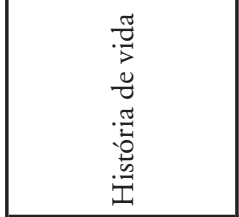 & 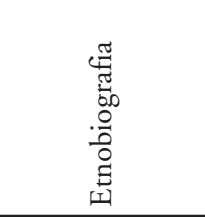 & 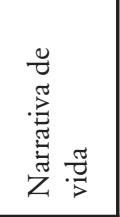 & 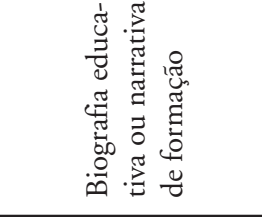 \\
\hline
\end{tabular}




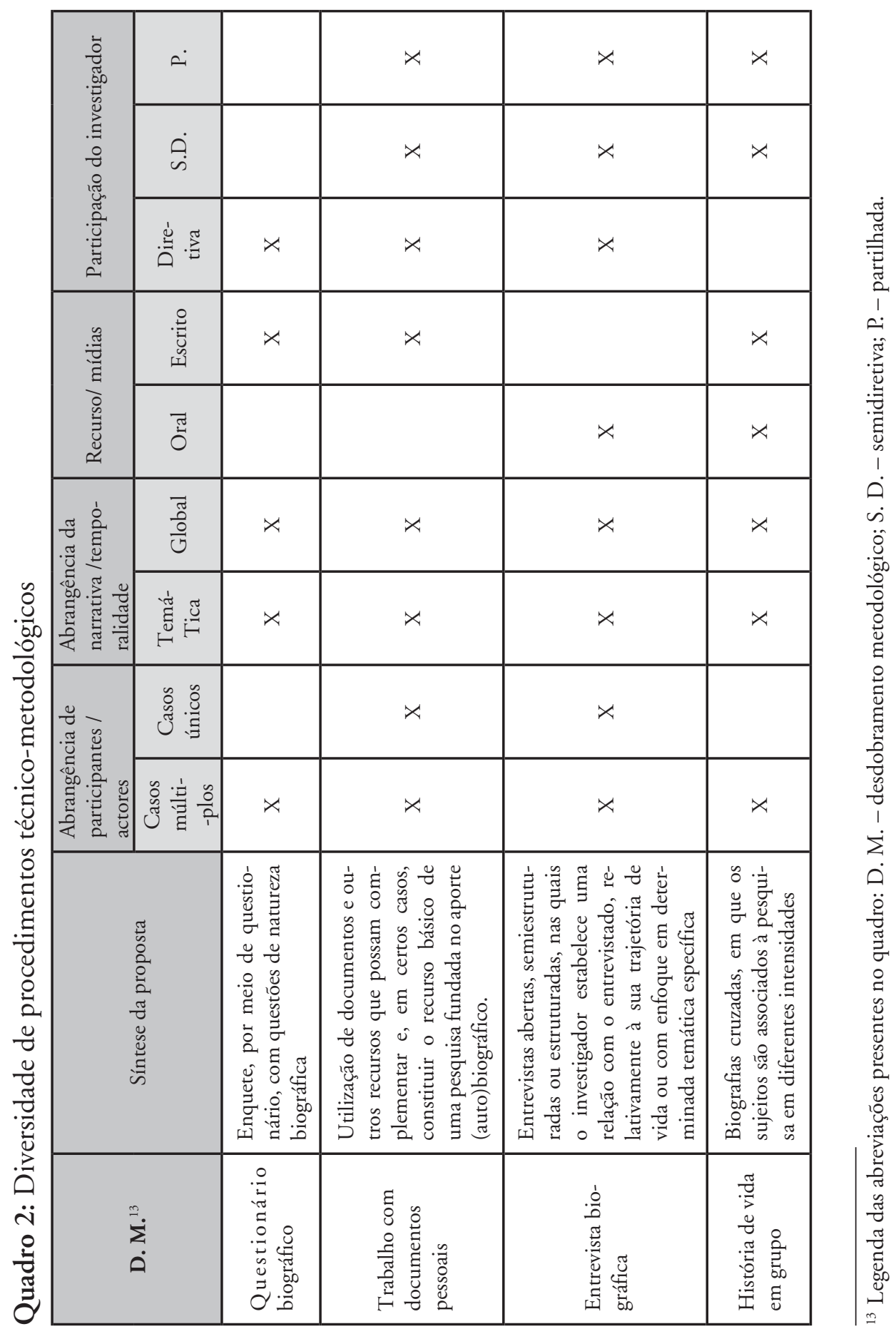




\begin{tabular}{|c|c|c|c|}
\hline$x$ & $x$ & $x$ & $x$ \\
\hline & & $x$ & $x$ \\
\hline$x$ & $x$ & $x$ & $x$ \\
\hline$x$ & $x$ & & \\
\hline$x$ & & $x$ & $x$ \\
\hline$x$ & $x$ & $x$ & \\
\hline & $x$ & $x$ & $x$ \\
\hline$x$ & $x$ & $x$ & $x$ \\
\hline 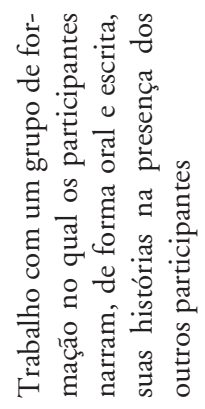 & 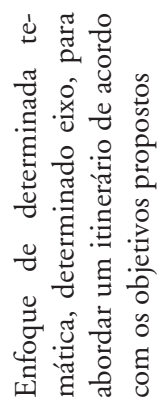 & 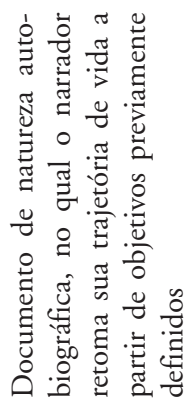 & 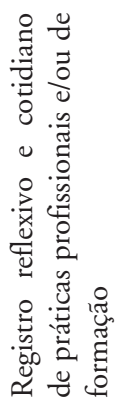 \\
\hline 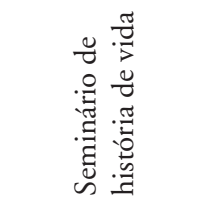 & 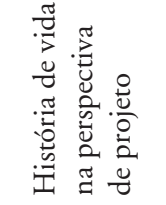 & 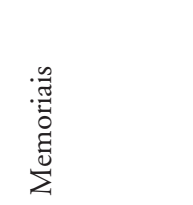 & 乎 \\
\hline
\end{tabular}


A forma de organização dos quadros e a marcação das diferentes ênfases indicam apenas uma das leituras possíveis com base nas referências citadas, o que sinaliza que esta é uma dentre tantas outras formas de sistematização. Essa observação é importante porque reafirma a polifonia teórica e a diversidade metodológica nesse campo de estudos, movimento que pode ser observado tanto nos trabalhos ligados às ciências sociais de forma geral como nos especificamente focados sobre a formação docente. ${ }^{14}$

Bueno et al. (2006, p. 388) trazem uma importante contribuição ao estudo das histórias de vida no campo educativo, por meio de uma ampla revisão de literatura com enfoque sobre o período de 1985 a 2003, privilegiando os temas "formação de professores" e "profissão docente". As autoras também enfatizam a dificuldade de categorização dos trabalhos, já que estes se caracterizam por grande dispersão temática, metodológica e de referenciais teóricos, compondo um conjunto diverso de combinaçōes, inclusive observando a utilização de mais de uma denominação em um mesmo trabalho, dando a ideia de que são sinônimos.

Para analisar, então, os trabalhos estudados, tomamos como indicativos a categorização de Nóvoa (1992a, p. 20) e a sistematização dos quadros apresentados. Na literatura portuguesa, encontramos uma ênfase preponderante em objetivos teóricos, centrados na investigação, e alguns trabalhos voltados para a perspectiva da investigação-formação. A profissão docente é uma dimensão de pesquisa recorrente, seguindo-se investigaçôes centradas na pessoa e na prática dos professores. A tematização da profissão aparece, de certa forma, entrelaçada à dimensão pessoal, em questôes como: ciclos de desenvolvimento profissional; articulação entre o pessoal e o profissional na construção dos perfis docentes; e lembranças de experiências profissionais e pessoais que marcam determinado período histórico. Há ainda investigaçôes com aporte nas histórias de vida centradas na prática docente, em que podemos ressaltar: o acompanhamento e a investigação sobre a docência; o desafio da prática em determinada disciplina; e as dinâmicas escolares.

Do ponto de vista metodológico, os trabalhos centrados nos professores apontam, especialmente, a utilização de entrevistas biográficas, registrando-se também o desenvolvimento de seminários de histórias de vida, abordagens

\footnotetext{
${ }^{14}$ No capítulo 2, aprofundamos aspectos da diversidade metodológica.
} 
etnobiográficas e o trabalho com documentos. O número de sujeitos participantes das investigações é variado, registrando-se, nos trabalhos analisados, apenas um relato de caso único $;^{15}$ os demais são estudos múltiplos. A maioria dos textos estudados focaliza narrativas temáticas, centradas nos objetivos da investigação, e alguns desenvolvem a análise considerando a globalidade da vida. Quanto à atuação do investigador, observamos uma perspectiva semidiretiva, nomeadamente nas entrevistas biográficas, ou seja, há um roteiro ou grandes linhas, mas os participantes são convidados a uma narrativa com liberdade de expressão. ${ }^{16,17}$

Tomando como referência a categorização de Nóvoa (1992a), encontramos, na literatura brasileira estudada, ênfase nos objetivos essencialmente emancipatórios, centrados na investigação-formação, e trabalhos voltados para objetivos teóricos, ligados à investigação. Quanto às dimensões mais focalizadas, os trabalhos centram-se, de forma preponderante, nas temáticas ligadas à profissão, seguindo-se a prática e a dimensão da pessoa do professor. A análise das referidas dimensões indica que se encontram imbricadas em torno das seguintes temáticas: desenvolvimento profissional, construção dos saberes docentes e estudo de trajetórias de vida. Situamos ainda um conjunto mais especificamente ligado à formação de professores, como: histórias de formação, estudo da formação de futuras professoras, processos de formação contínua com aporte na rememoração, formação e construção de identidades. Observamos, então, na literatura brasileira, grande incidência em abordagens sobre a formação.

As metodologias utilizadas incluem ampla diversidade de abordagens e desdobramentos. Tal como na literatura portuguesa, as entrevistas biográficas são preponderantes sobre as demais perspectivas. Nos textos analisados, há também tendência para trabalho com casos múltiplos, ressaltando-

15 Estudo realizado por Vasconcelos (1995).

${ }^{16}$ Cf. Cavaco (1995), Gonçalves (1992), Moita (1992), Sanches (1995), Santana (1993), Sarmento (2002), Vasconcelos (1995) e Vieira (1999).

${ }^{17}$ Nos seminários de histórias de vida, os participantes e o/a investigador/a produzem suas biografias educativas, que são coletivamente analisadas; portanto, a dinâmica da investigação-formação é partilhada entre todos. A abordagem etnobiográfica consiste na incorporação de outras metodologias, como observação participante, entrevistas, análise de diários, questionários e etnografia em sala de aula. Quanto ao uso de documentos, fizemos o registro do trabalho de Sarmento (1994), que estuda narrativas de professores publicadas em revistas independentes de divulgação educacional entre 1987 e 1991, com o objetivo de analisar as concepções dos professores sobre a dinâmica e a organização escolar. 
-se, contudo, a presença de cinco estudos de caso único. ${ }^{18}$ A maioria dos estudos aborda a história de vida em uma perspectiva temática ${ }^{19}$ e semidiretiva, do ponto de vista da atuação do investigador, ou seja, são trabalhos que incentivam a narrativa de aspectos ligados aos objetos de estudo das investigaçôes propostas. $\mathrm{O}$ investigador organiza um conjunto de eixos ou questôes, mas valoriza a liberdade e os encaminhamentos dados pelos participantes.

Além do diálogo entre Brasil e Portugal, procuramos alargar o olhar incluindo a literatura francófona, por meio de alguns livros e, especialmente, artigos publicados na Revista Education Permanente. Tomamos aqui, então, dos textos estudados, apenas os que estão voltados para abordagens de investigação-formação, desenvolvidos em contexto da formação universitária, envolvendo alunos de diversas licenciaturas, inclusive em ciências da educação. Os trabalhos de Baudouin e Turkal (2000), Dominicé (1988a), Dominicé et al. (2000a), Dominicé (2000) e Lerbet (1990) trazem as histórias de vida para a academia como instrumento de formação. As propostas metodológicas centram-se no desenvolvimento de seminários, nos quais, em abordagens orais e escritas, os estudantes desenvolvem e analisam, coletivamente, suas biografias educativas em um movimento de análise dos processos de aprendizagem. Como já observamos, tal perspectiva metodológica tem influenciado diversas práticas no campo da formação docente.

Vemos, assim, o aporte (auto)biográfico mobilizando diferentes investigaçōes e práticas sobre os/as professores/as, especialmente no campo da formação docente. É preciso reafirmar que os trabalhos lidos constituem apenas um fragmento muito reduzido de um amplo universo de produções. Foram os estudos possíveis nesse momento e, se não nos podem oferecer um quadro, trazem indícios e pistas das cores e matizes que se destacam nos estudos dessa área. Contribuem ainda para futuras leituras e estudos

\footnotetext{
${ }^{18}$ Cf. Azambuja e Oliveira (2001), Caldeira (2000), Dias e Cicillini (2002), Miranda (2005) e Polettini (1998).

${ }^{19} \mathrm{O}$ estudo realizado por Bueno et al. (2006) também reforça essa questão quando afirma a predominância, quase exclusiva, da perspectiva das "histórias de vida a serviço de projeto", utilizando a expressão de Josso (2002a), ou seja, uma abordagem temática, marcada por determinado recorte.
} 
da literatura; porém, principalmente, no contexto deste livro, ajudam-nos a visualizar o campo em que procuramos trabalhar.

\section{Contribuiçóes das histórias de vida em contextos de formação de professores}

As histórias de vida se inserem, como vimos, num contexto epistemológico referido à busca de uma análise complexa dos fenômenos sociais e humanos, uma análise que incorpora a subjetividade individual e coletiva. O trabalho com essa abordagem, no campo da investigação e da prática de formação de professores, focaliza a narrativa do sujeito, possibilitando aflorar a voz dos/as professores/as, sua linguagem e suas práticas socialmente construídas na docência. O/A professor/a deixa de ser objeto para ser sujeito da pesquisa e coloca-se como autor que ressignifica sua trajetória ao longo do processo de investigação.

Olhando a literatura, encontramos a enunciação de um conjunto de potencialidades do ponto de vista epistemológico e pedagógico, nomeadamente centradas na formação de adultos e de professores. Situaremos, de forma inicial, as contribuiçóes referidas de forma geral e, a seguir, as referências específicas na investigação e na prática da formação de professores.

\section{Contribuições no campo educativo e na formação de adultos}

Do ponto de vista epistemológico, as histórias de vida colocam-se, como já nos ensinou Ferrarotti (1990), como possibilidade de mudança e ruptura em relação à ciência clássica, movimento que lança outro olhar à vida e à sua dinâmica e, consequentemente, institui outra forma de entender e trabalhar com as ciências humanas. E é assim que esse aporte nos confronta com novas perspectivas metodológicas e teóricas. Nessa dimensão, sintetizamos, no esquema a seguir, as principais ênfases da literatura estudada. 
Figura 1: Contribuições no campo educativo e na formação de adultos: principais ênfases da literatura estudada

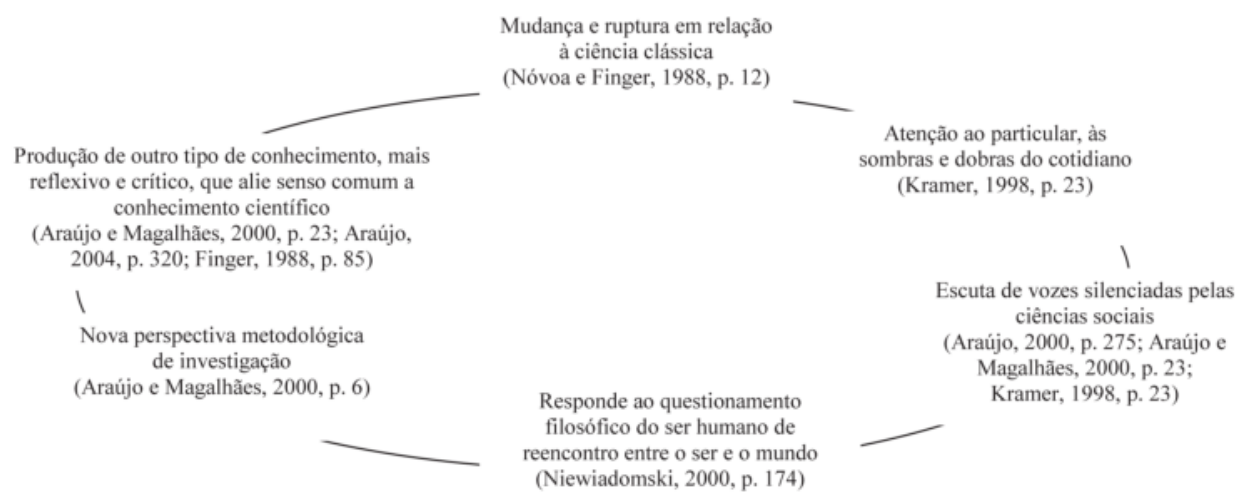

O particular e as dobras do cotidiano saem do lugar de sombra e assumem a cena como sujeitos da investigação. Aqui, a literatura destaca de maneira enfática a possibilidade de escuta das vozes silenciadas, em que investigadores e sujeitos da pesquisa têm o lugar da fala e, em alguns casos, o da interpretação. Nesse caminho dialógico de relação com o mundo e com a ciência, surge um conhecimento mais reflexivo e crítico, aliando o senso comum ao conhecimento científico. Entretanto, além da ruptura epistemológica, encontramos nas histórias de vida um sentido ontológico de reencontro do homem consigo mesmo, com as pessoas, com o mundo.

É a potencialidade epistemológica e ontológica dessa abordagem que fertiliza práticas de investigação e formação em diferentes campos. Para a formação de adultos, o aporte (auto)biográfico é tomado como uma "nova epistemologia de formação", pois coloca a reflexividade crítica no centro das dinâmicas teórico-metodológicas, engendrando práticas que implicam o sujeito, permitindo-lhe "tornar-se actor do seu processo de formação, pela apropriação retrospectiva do seu percurso de vida” (Nóvoa e Finger, 1988, pp. 12, 114, 117).

Nessa perspectiva, a literatura estudada é recorrente na articulação entre as histórias de vida e a formação. A narrativa oral e/ou escrita da trajetória de vida coloca o sujeito frente aos movimentos formativos de sua existência, potencializando as relaçôes com o saber e a responsabilidade quanto aos pro- 
jetos de futuro. Destacam-se, ainda, a possibilidade de explorar processos específicos de formação profissional e a valorização e a oportunidade de reelaboração dos saberes da experiência. ${ }^{20}$

$\mathrm{O}$ aporte (auto)biográfico em contextos de formação de adultos preconiza a análise da trajetória em uma articulação entre presente, passado e futuro, permitindo o exame da história, a análise das inflexões fortes que marcam o percurso e o trabalho com os projetos de vida (Berton, 2000, p. 160; Francequin e Blanché, 2000, p. 192). Centra-se na busca de uma visão global sobre o sujeito e sua experiência de vida (Dominicé, 1999, p. 147; Padé, 1992, p. 169).

A literatura também sinaliza a importância das relações entre histórias de vida e identidade, pois a visão sintética sobre os percursos pessoais pode favorecer "efeitos de unificação", certo sentimento de identidade. Uma representação de si, de seu saber, de seu fazer, encaminhando a possibilidade de uma legitimação pessoal e profissional (Berton, 2000, p. 160; Finger, 1988, p. 85; Francequin e Blanché, 2000, p. 192). Encontramos ainda, nas análises de Baudouin e Turkal (2000, p. 54) e Finger (1988, p. 85), um objetivo emancipatório, no aporte (auto)biográfico em formação de adultos, ligado às possibilidades de transformação instituinte dos sentidos das experiências pessoais e coletivas, a mudança das relações com o mundo.

\section{Contribuiçôes ligadas à formação docente}

Os mesmos eixos de análise podem ser observados na literatura voltada aos professores e à sua formação. No entanto, ainda outras ênfases se destacam e indicam a especificidade dos estudos ligados à docência. Inicialmente, o aporte (auto)biográfico reivindica uma nova epistemologia de investigação e de formação. Na pesquisa em educação, vislumbramos a potencialidade das "histórias capazes de nos surpreender" (Araújo e Stoer, 1993, p. 18), capazes de trazer a voz dos professores e professoras sobre diversos aspectos ligados à profissionalidade, à prática e às carreiras. Buscamos um diálogo partilhado em que pesquisadores e sujeitos responsabilizam-se pelo processo de construção de saberes.

${ }^{20}$ Cf. Baudouin e Turkal (2000, p. 54), Carino (1999, p. 154), Josso (1994, pp. 74-5), Lainé (2000, p. 40) e Padé (1992, p. 169). 
Nos estudos sobre a docência, ancorados no sentido histórico e sociológico desse aporte teórico-metodológico, também a principal contribuição destacada é a possibilidade de escuta e de intercâmbio com sujeitos que, na ciência clássica, foram tomados como objetos. Vamos ao encontro da valorização da vida, das vozes, das subjetividades, como alternativa de investigação para reconstruir a história, as políticas educativas e as práticas de formação (Kramer, 1998, p. 23; Mignot, 2003, p. 136).

Nesse contexto, ressaltamos trabalhos que focalizam especificamente a subjetividade feminina, não apenas no sentido de ter os relatos narrativos como fonte de informação, mas para garantir a retomada do espaço do feminino, revelando as lutas do cotidiano pessoal e profissional em um "processo simultâneo de descoberta de si como mulheres e professoras, de reconstrução do sentido da vida profissional" (Sousa et al., 1996, p. 75; Araújo, 1995, p. 351, 2000, pp. 282, 287).

No livro As pioneiras na educação: as professoras primárias na viragem do século: contextos, percursos e experiências - 1870-1933 (Araújo, 2000), a narrativa das professoras é apresentada não só na perspectiva de perceber os processos políticos e ideológicos do tema em questão - a feminização do magistério -, mas na de incluir a fala das professoras que vivenciaram as tramas da docência na própria vida. A autora destaca a importância de trazer as vozes que foram tradicionalmente esquecidas pelo discurso acadêmico tanto nas ciências sociais como na educação em Portugal. Registra-se, assim, a importância de dar sentido à experiência vivida, tendo como referência os "documentos da vida".

Além da diversidade de estudos centrados na investigação de temáticas ligadas à docência, ressaltamos a vinculaçẫo desse aporte a uma nova epistemologia de formação. Em si, o aporte (auto)biográfico apresenta uma natureza formadora, produz conhecimento e, potencialmente, pode constituir uma experiência de transformação pessoal e coletiva. Nesse sentido, Couceiro reforça que tal aporte promove efeitos formativos e autoformativos, "mesmo quando dirigido a um objeto de investigação" (2002b, p. 156). Trabalhando com as histórias de leitura de professores das décadas de 1920 a 1960, no Rio de Janeiro, Kramer (1998, p. 29) também ressalta o potencial formativo das entrevistas biográficas tanto para o pesquisador como para os entrevistados, ou seja, mesmo que o objetivo seja apenas a recolha de informaçōes por meio de narrativas, o movimento de elaboração desenvolvido pelo sujeito tende a 
ser instituinte de novas formas de ser e de estar no mundo. Assim, reafirmamos que, no campo educativo, a especificidade desse referencial é a formação. As narrativas não apenas descrevem a realidade, mas também são produtoras de conhecimento individual e coletivo e, no caso dos/as professores/ as, potencializam os movimentos de reflexão sobre as próprias experiências, teorias e práticas. O saber da experiência assume centralidade, envolvendo as diversas dinâmicas formativas ao longo da vida e os movimentos em direção ao futuro. ${ }^{21}$

O desenvolvimento de investigações e práticas de formação centradas nas histórias de vida traz, tal como na formação de adultos em geral, a densidade da dimensão temporal, ou seja, os/as professores/as são convidados/ as a tematizar a vida no percurso do tempo, na dialética entre a memória do passado, as experiências do presente e os projetos de futuro, em um sentido de balanço. Há, na literatura, indicativos de um movimento propositivo de construção da vida e dos futuros pessoais, profissionais, individuais e coletivos (Couceiro, 2002a, pp. 152, 157; Bragança, 2003).

A perspectiva de trabalho, por meio da história de vida, indica a possibilidade de reconstruir as imagens do passado e do presente, abrindo canais para revitalização pessoal, profissional e, potencialmente, social. É assim que Nico sintetiza, afirmando que os relatos (auto)biográficos constituem

um momento privilegiado de avaliação individual, durante o qual o indivíduo ao revisitar o seu passado traz para a superfície da memória os acontecimentos que, de uma forma ou de outra, determinaram aquilo que ele é naquele momento. É nesses instantes que, por vezes, se compreende o presente e se redefinem os projectos para o futuro (1995, p. 96).

As narrativas de professores e professoras apontam o forte entrelaçamento entre o individual e o coletivo. A história de vida, no campo da formação docente, faz emergir a densidade da produção social de determinados significados apropriados pelo sujeito. Quem narra traz sempre os processos sociais de sua produção da narrativa. Temos, assim, uma ênfase no papel do sujeito em sua formação e no processo coletivo de construção dos saberes.

${ }^{21}$ Cf. Couceiro (1998, p. 55), Catani et al. (1997, pp. 32-3), Cunha (2001), Dias e Cicillini (2002) e Vaz (2001). 
Se a especificidade do aporte (auto)biográfico, no campo educativo, centra-se na formação que vem do movimento de tematização da vida no percurso do tempo - movimento este essencialmente instituinte do saber e prenhe da dialética entre o indivíduo e a sociedade -, a reflexão é o caminho que materializa e dá sentido a esse envolvimento vital, autopoiético. É por meio da reflexão que professores e professoras narram e problematizam sua sócio-história de vida. As abordagens de pesquisa-formação não buscam na narrativa um ato mecânico ou descritivo, mas, em outra perspectiva, a recriação do passado e a construção do futuro, por meio de um voltar à origem, de um inventário das experiências fundadoras.

Assim, a reflexão é uma travessia fundamental para as histórias de vida no campo da formação, é um olhar para dentro, um revisitar da vida em suas múltiplas relaçôes, tanto para análise dos percursos pessoais como profissionais. Trata-se da reflexividade crítica, como autoanálise que repercute na compreensão das concepções que temos, das influências que sofremos, podendo, nesse sentido, ser geradora de conscientização, de um ressignificar do vivido. $\mathrm{Na}$ formação de professores, esse ressignificar assume um carácter emancipatório, articulando dimensões ontológicas, pedagógicas e políticas, ou seja, um carácter instituinte de formas pessoais, profissionais e sociais de estar no mundo e com as pessoas.

Do ponto de vista ontológico, o aporte das histórias de vida procura o reencontro do ser com ele mesmo em partilha com as pessoas e o mundo; nas palavras de Couceiro, tornar "possível ao sujeito a elaboração da coerência que lhe permite ir-se produzindo como pessoa” (1995b, p. 336). A autorreflexão aponta um potencial de transformação do sujeito, de reconstrução das trajetórias, reconfigurando sentidos da vida na globalidade da existência (Cunha, 2001; M. A. S. Franco, 2000).

É ainda na dimensão ontológica que situamos as relações estabelecidas entre narrativa das histórias de vida e identidade. Referindo-se às potencialidades do trabalho memorialístico no campo das ciências sociais como um todo, Pollak (apud Catani et al., 1997, p. 19) afirma que o recurso às histórias de vida constitui, nesse sentido, um instrumento de reconstrução da identidade, não trazendo apenas relatos factuais. No trabalho com a memória, fragmentos do passado se articulam ressignificando uma imagem sobre o "ser" professor/a, trazendo um "sentimento de identidade" (Pollak apud Catani et al., 1997, p. 23). As histórias de vida ajudam a compreender o processo identitário dos professores/as, de forma situada no contexto sócio-histórico, pela articulação entre dimensões 
pessoais, profissionais e sociais no curso do tempo (Catani et al., 1997, p. 40; M. A. S. Franco, 2000).

O objetivo pedagogicamente emancipador aparece com força na literatura ligada à formação de professores, vertente que destaca, no aporte (auto)biográfico, a possibilidade de reflexão e ressignificação das práticas docentes. ${ }^{22}$ Nesse sentido, a narrativa coloca-se como possibilidade "de produção de imagens e fazeres instituintes, fazeres que recuperem antigos sonhos de justiça, que questionem práticas instituídas, buscando formas instigantes de estar na profissão" (Bragança, 2003, p. 1). Catani et al. (1997, p. 19) destacam que esses relatos podem favorecer "o redimensionamento das experiências de formação e das trajetórias profissionais e tendem a fazer com que se infiltrem na prática atual novas opções, novas buscas e novos modos de conduzir o ensino"; a reflexão sobre as trajetórias na vida e na profissão como uma possibilidade de reinterpretação de si e da prática pedagógica, de encontro com as experiências significativas e as influências sobre a prática (Catani et al., 1997, pp. 19, 32, 33; M. A. S. Franco, 2000; Kenski, 1997, pp. 95-6). Nessa dimensão, podemos trazer o sentido da memória e da narração, para os professores, como tempo de trabalho, de reorganização dos sentidos e do futuro na profissão (Bosi, 1994; Bragança, 2001a; Pérez, 2003a; Souza, 2004).

Além disso, as histórias de vida revestem-se de um objetivo politicamente emancipador, já que, potencialmente, as transformações se dão também em uma perspectiva ampla, social.

Num tempo veloz e fugaz, em que a alienação, o isolamento e o silenciamento das experiências nos forçam a perder nossa memória coletiva, rememorar e compartilhar memórias é uma ação rebelde que adquire um caráter de resistência política; a memória compartilhada é uma forma de não sucumbir ao esquecimento que o tempo acelerado da vida social nos impóe (Pérez, 2003a).

É como ação rebelde que o aporte (auto)biográfico se afirma, como um caminho de aprendizagem coletiva, incorporando vozes silenciadas pela política

${ }^{22}$ Cf. Abrahão (2006a, 2006b), Bastos (2003), Bragança (2003), Bueno (1996, 1997, 2002), Bueno et al. (1993), Caldeira (2000), Castro (2005), Catani e Vicentini (2003), Catani et al. (1997), Cunha (2001), Dias e Cicillini (2002), M. A. S. Franco (2000), Kenski (1997), Kramer (1998), Miranda (2005), Pérez (2003a, 2003b), Ramalho et al. (2000), Sousa et al. (1996), Souza (2004) e Vaz (2001). 
educacional e de formação docente, produzindo uma contracultura em oposição à oficial. Coloca-se como uma possibilidade de refazer caminhos e imagens, a partir do lugar da experiência e do saber docente, num processo profundamente partilhado. ${ }^{23}$

As nossas narrações abertas são um convite para a presença de outras narrações. Reescrevemos a história e a política da educação à luz das reflexôes sobre a própria experiência vivida, desejando nelas inscrever as pulsações dos educadores, as versões das nossas lutas, tantas vezes silenciadas. Recolocamos o legado que recebemos do passado como herança grávida de futuros, assim mesmo no plural, onde a dignidade de ensinar e do saber não estejam sacrificadas pelas opressões, mesmo aquelas mais sutis e miúdas, que perversamente nos afligem e sacrificam nossa tão arranhada liberdade (Linhares e Nunes, 2000, p. 8).

As narrações, como um dos caminhos no campo da formação docente, assentam-se na abertura de um diálogo que faz e se refaz na luta cotidiana da vida e da profissão e que se amplia retomando as lutas silenciadas no contexto sócio-histórico. Assim, no plural, vai-se fazendo a formação, na intensa construção da vida.

Após esse olhar sobre a literatura, buscamos, por meio do esquema a seguir, sintetizar as principais contribuições para o campo da formação de professores.

Figura 2: Contribuições ligadas à formação docente

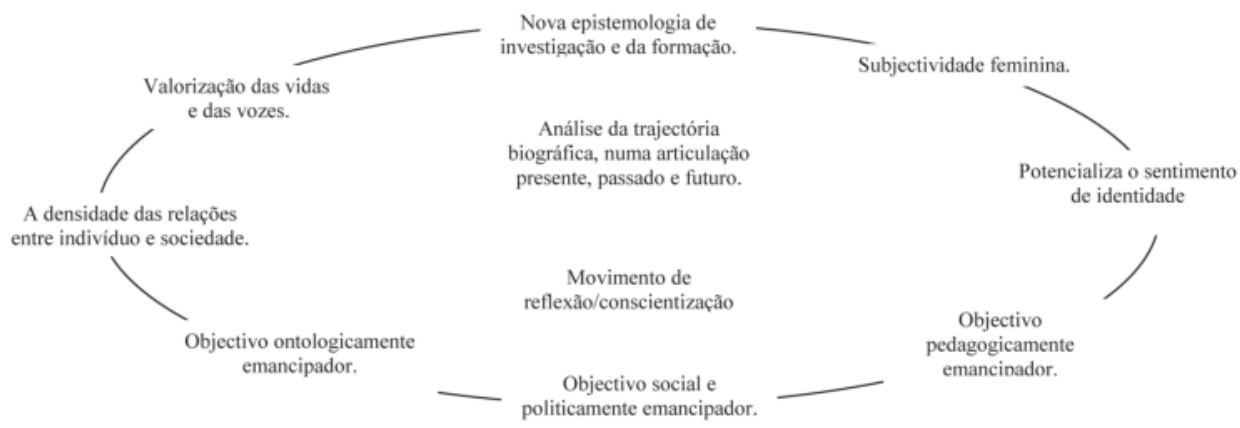

${ }^{23}$ Cf. Araújo (2000, p. 7), Araújo e Magalhães (2000, p. 27), Bueno (1996, 1997), Catani et al. (1997, pp. 32-3) e Kramer (1998, p. 23). 


\section{Desafios e cuidados}

Apesar do conjunto de contribuições destacadas pela literatura, é importante frisar que estas constituem apenas potencialidades, ou seja, os caminhos das histórias de vida, no campo da formação docente, apontam possibilidades. O resultado dos movimentos e processos, tanto no nível das investigações quanto no da formação, depende da intensidade da experiência, ou melhor, de que o encontro reflexivo constitua, efetivamente, uma experiência tanto para o investigador como para os protagonistas da pesquisa. É preciso se deixar tocar, mobilizar e transformar. Nesse sentido, temos um caminho aberto.

É importante, ainda, enfatizar a atenção e o cuidado epistemológico no trabalho com o referido aporte, pois, se são grandes as possíveis contribuições, também o são os perigos de desvio. $\mathrm{Na}$ revisão da literatura relativa aos trabalhos brasileiros, realizada por Bueno et al. (2006, p. 403), encontramos preocupações que incidem sobre a dispersão da produção, a ausência de diálogo entre as pesquisas, tanto com a produção nacional como internacional, a imprecisão conceitual ligada às muitas terminologias utilizadas e também a desconsideração da história das histórias de vida.

Nóvoa (1992a, p. 19) alerta para o necessário cuidado de que essa perspectiva teórico-metodológica não seja tomada como um modismo e, da mesma forma, chama nossa atenção para as fragilidades. Sinaliza a ausência de uma teoria de formação de adultos que dê sustentação aos estudos nesse campo e as fragilidades conceituais das ciências da educação, destacando ainda críticas recebidas pela utilização desse aporte. No campo da psicologia, as observações caem "na frágil consistência metodológica, na ausência de validade científica ou nas dimensões analíticas implícitas"; e, no campo da sociologia, no "esvaziamento das lógicas sociais, em uma excessiva referência aos aspectos individuais e na incapacidade de aprender as dinâmicas colectivas de mudança social” (Nóvoa, 1992a, p. 19). Segundo o autor, a ampliação do número de trabalhos "tende a dar guarida a experiências pouco consistentes e até eticamente reprováveis; finalmente, porque facilita uma apropriação acrítica e, portanto, a redução das suas potencialidades transformadoras" (Nóvoa, 1992a, p. 19); ou seja, é preciso haver profundidade teórica e cuidado metodológico - as histórias de vida não devem ser colocadas como mais uma daquelas panaceias que advogam a possibilidade de se constituírem como "o 
caminho". O que temos, pelos indícios das ciências humanas e dos trabalhos no campo educativo, são pistas e sinais de uma das vias possíveis de serem perseguidas.

A narração das histórias de vida vem como movimento propriamente humano de contar histórias e ressignificar experiências do passado que se vão desdobrando em projetos de futuro. No caso da formação docente, ao narrar o passado, vemos surgir uma versão sobre nós mesmos, os encontros e desencontros com a profissão e, ainda, as imagens da docência entranhadas no imaginário coletivo e individual. Encontramos, dessa forma, na investigação e na prática, múltiplas contribuições do aporte (auto)biográfico para a formação docente, que a presente investigação busca focalizar, especialmente quanto à possibilidade de análise dos movimentos por meio da pesquisa-formação. 


\section{Capítulo 4 \\ Memória, narração e experiência: um "círculo virtuoso"}

\section{Pesquisa e educação: a perspectiva da complexidade}

Após o olhar dirigido à trilha das histórias de vida no campo das ciências sociais e humanas e no campo educativo, buscamos, aqui, indicar as referências conceituais e metodológicas que se entrelaçam aos caminhos perseguidos. Morin indica o necessário movimento de resgate da dimensão subjetiva do trabalho científico, buscando a superação da ruptura entre cultura humana e cultura científica. Traz, assim, um apelo à mudança de olhar - um caminho a ser feito -, uma religação da ciência com a consciência. Por essa abordagem, buscamos recuperar a "reflexividade filosófica" dos processos científicos, trazendo a densidade de "nossas vidas e nossas reflexōes como o indivíduo, a subjetividade, o homem, a sociedade, a vida [...]". É a busca de trazer o homem para as ciências humanas (Morin e Moigne, 2000, p. 28).

A tradição cartesiana e todo desenvolvimento histórico dos processos de construção do conhecimento fizeram o movimento do simples para o complexo, e o pensamento científico contemporâneo tenta ler a complexidade do real. "A complexidade nos aparece, à primeira vista e de modo efetivo, como irracionalidade, incerteza, confusão, desordem" (Morin e Moigne, 2000, p. 47). Nesse sentido, Morin propõe um tetragrama, um movimento dialético que incorpora "ordem - desordem - interaçôes - organizações" (Morin e Moigne, 2000, p. 53). O conhecimento científico não se afirma, portanto, na certeza, mas na curiosidade epistemológica, na abertura para a descoberta 
e para o conhecimento dos mistérios inesgotáveis do mundo. O paradigma simplicador, que tem sido hegemônico nos processos de produção do conhecimento, "[...] ignora o singular, o concreto, a existência, o sujeito, a afetividade, os sofrimentos, o gozo, os desejos, as finalidades, o espírito, a consciência [...]". Tal perspectiva, contudo, entra em crise no século XX, tendo seus pilares abalados pelo "surgimento da desordem, da não separabilidade, da não redutibilidade, da incerteza lógica” (Morin e Moigne, 2000, p. 100).

A perspectiva simplificadora apresenta expressão no paradigma positivista que propõe uma separação entre sujeito e objeto, utilizando metodologias nomeadamente estatístico-experimentais, com orientação hipotético-dedutiva, objetivando estabelecer regularidades ou leis de aplicação universal. A implicação intersubjetiva entre investigador/a e participantes da investigação na construção de um saber dialógico e partilhado, assim como o olhar para as complexidades políticas, econômicas e sociais, coloca-nos frente ao interpretativismo crítico como caminho de análise.

O paradigma interpretativo toma como referência do trabalho científico a interpretação, que vem por meio da relação intersubjetiva entre investigadores/as e sujeitos envolvidos, uma interação que é em si uma forma de ação, traduzindo a interdependência entre conhecer e agir. Nesse sentido, assenta-se especialmente em metodologias qualitativas, participativas e de investigação-ação, rejeitando a formulação de leis gerais e afirmando a busca de uma ciência não normativa. A perspectiva interpretativa alia-se ao paradigma crítico na rejeição do positivismo, bem como em seus referenciais metodológicos, trazendo, entretanto, a contribuição de articular a análise interpretativa aos "contextos políticos e ideológicos em que se geram as condições da acção social" (Sarmento, 2003, pp. 141-2). Tomando, assim, referência na perspectiva marxista, especialmente na teoria crítica da Escola de Frankfurt, a abordagem crítica, articulada ao interpretativismo, ajuda-nos a recuperar a centralidade do poder na dinâmica das relações sociais:

A ênfase está colocada nas dimensões hermenêuticas, sem que se ignore que toda a interpretação global é também a análise das condições de poder em que ocorre a acção, nem se iluda a própria dimensão política do acto interpretativo: a investigação dos contextos de acção visa precisamente dar sentido, e todo o sentido é um acto de ordenação do mundo (Sarmento, 2003, p. 144, grifos do autor). 
Tendo como perspectiva o interpretativismo crítico, Sarmento (2003) apresenta quatro pressupostos epistemológicos, que tomamos, também, como referência de análise. O primeiro afirma a singularidade em contraposição à lei universal, procurando, nas relações sociais, as diferenças, as variações, o inesperado, o fluido e o ambíguo, imersos, como estão, nos contextos macroestruturais mais amplos. Há uma recusa da explicação causal como definição de critérios universais e de verdade e a valorização hermenêutica de "redes, fluxos, implicações mútuas, constrangimentos, representações sociais, sentidos plurais" (Sarmento, 2003, p. 145).

O segundo pressuposto focaliza as dimensóes intersubjetivas que envolvem a construção do conhecimento, o ouvir o outro como referência de uma ciência mais humana; o interpretativismo crítico postula, assim, uma dupla hermenêutica que efetiva a translação entre as interpretações dos sujeitos envolvidos e dos/as investigadores/as.

Essa interação entre os envolvidos na investigação se dá em um contexto essencialmente linguístico, sendo esse o terceiro pressuposto epistemológico. Nesse aspecto, é importante ressaltar o sentido político que envolve a linguagem, a compreensão de que "o poder da linguagem envolve também a linguagem do poder", e, assim, tanto investigador/as como participantes fazem parte de "um jogo social politicamente investido" (Sarmento, 2003, pp. 145-9).

A consciência tanto da subjetividade como do sentido político de nossa presença no mundo encaminha-nos, então, ao quarto pressuposto: o princípio da reflexividade. A reflexividade metodológica coloca-se como método, "dado que esse princípio é a principal barreira que pode impedir a transposição não vigiada dos enviesamentos e preconceitos ideológicos do investigador sobre a sua observação e as suas interpretaçôes" (Sarmento, 2003, pp. 150-1). Considerando a implicação do/a investigador/a, a construção do conhecimento não se dá de forma linear, mas envolve escolhas, cortes, determinado foco do olhar, e a reflexividade crítica permite, justamente, interrogar "o sentido do que se vê e por que se vê e se acrescenta o escopo do campo de visão a um olhar-outro, coexistente no investigador" (Sarmento, 2003, p. 151).

Tomar essa perspectiva como referência, coloca-nos frente ao desafio de buscar sentidos do processo formativo por meio de uma abordagem humana, intersubjetiva e instituinte, entendendo que a utilização das histórias de vida não se reduz, na presente investigação, a uma perspectiva técnica ou 
metodológica, mas indica uma imbricação teórico-metodológica que, como ensinou Ferrarotti (1990), nos lança para fora do quadro lógico-formal positivista e nos confronta com a complexidade humana dos processos sociais. O caminho da pesquisa-formação e das histórias de vida localiza-se, nessa tensão, em uma abordagem que procura a epistemologia da partilha, da construção conjunta, em que investigador e sujeitos da pesquisa colocam-se como "aprendentes", porque, parafraseando Freire (1992), ao mesmo tempo pesquisam e aprendem; e pesquisam e aprendem tematizando a própria vida em suas interfaces pessoais, acadêmicas e profissionais.

Partindo dessas referências epistemológicas, o presente capítulo procura dar visibilidade à referida imbricação teórico-metodológica que envolve a utilização do aporte (auto)biográfico. Assim, encontra-se distribuído em itens que articulam a discussão dos principais conceitos e os indicativos de caminhos que propomos trilhar.

\section{Reflexóes conceituais}

\section{Memória, narração e experiência}

[...] Como falar de temas como memória, narração e experiência sem ser repetitiva? O movimento que me ocorre é de retorno, de passar em revista antigos conceitos, categorias, reflexões, e, em sentido de balanço, tentar perceber a forma como também eles foram sendo transformados ao longo do percurso, da vida, da pesquisa. Desejo, então, traduzir no referencial teórico não a frustração dos estudos que ainda não fiz, mas a retomada avaliativa do que está presente em mim como pessoa, como professora e pesquisadora e que, de alguma forma, foi conduzindo os movimentos da pesquisa e traduzindo-se na própria tese. Tudo isso me faz perceber que o texto que vou escrevendo sobre o tema 'memória, narração e experiência' vai se fazendo ele próprio em sentido autobiográfico, no revisitar de minha trajetória de estudo, no olhar sobre antigos textos, livros, pastas e fichamentos, onde reencontro sinais das referências que foram a pouco e pouco sendo construídas/desconstruídas e a abertura para novas formulações (19 fev. 2007). 
Os conceitos de memória, narração, experiência e subjetividade se articulam, compondo uma trama de entrelaçamentos, e o desafio aqui colocado é dar inteligibilidade às diferentes cores desse trançado, indicando também pistas para a compreensão de como esses conceitos se apresentam e se reconstroem no desenvolvimento da pesquisa.

Encontramos, na mitologia grega e na literatura infantil, intensas indagações que se manifestam como fundacionais, mas, ao mesmo tempo, se reatualizam e continuamente falam de nossa busca de sentido para a vida. Nessas linguagens não acadêmicas, também identificamos lampejos de sentidos atribuídos à reflexão sobre a memória, lampejos que se articulam a autores que tomamos como referência na composição de um quadro teórico reconstruído no movimento da própria pesquisa.

Mnemosyne, a deusa da memória, inspirava os poetas e os ajudava no reencontro com o passado, tornando-os, assim, imortais como o cosmos, pois pelos seus feitos poderiam ser lembrados por toda posteridade. $\mathrm{Na}$ Grécia antiga, o registro da memória afirma a possibilidade de continuidade, de luta contra a própria morte - o poeta passa, mas deixa sua narrativa inscrita na memória coletiva. Segundo Arendt (1972, pp. 72, 74), no mundo grego, se os mortais conseguissem fazer algo com permanência, como obras, feitos e palavras, isso os colocaria no terreno da imortalidade, e o homem encontraria seu lugar no cosmos, onde todas as coisas são imortais, exceto os homens. "A tarefa do poeta e historiador [...] consiste em fazer alguma coisa perdurar na recordação. E o fazem traduzindo práksis e léksis, ação e fala, nesta espécie de poièsis ou fabricação que, por fim, se torna a palavra escrita" (Arendt, 1972, pp. 72, 74).

Mas não só a mitologia traz a presença da memória como questão essencialmente ligada às tramas da vida humana. Também encontramos na literatura infantil outra fonte de reflexão que vem marcada pelo paradoxo entre a profundidade e a leveza do mundo infantil. O livro Guilherme Augusto Araújo Fernandes (Fox, 1995) conta a história de um menino que morava ao lado de um asilo e faz grande amizade com D. Maria Antônia. Entretanto, D. Antônia perde sua memória, e o menino decide, então, ajudá-la. Para isso, faz uma pesquisa na família e com os outros idosos do asilo sobre o que é memória e encontra as mais variadas respostas: a memória "é algo de que você se lembre", "algo quente", "algo bem antigo", "algo que faz chorar", "algo que faz rir", "algo que vale ouro". Mitologia e literatura infantil nos ajudam a ver 
a memória como caminho da imortalidade, como uma propriedade humana que envolve a afetividade e a magia.

Presente nas reflexões filosóficas, históricas e políticas, o debate sobre esse conceito vai apresentando multiformes dimensões, que, para nossa análise, agrupamos primeiro no que chamamos perspectiva fenomenológica e, posteriormente, política. Do ponto de vista de sua manifestação como fenômeno social, destacamos os sentidos de memória-fragmento, memória coletiva, memória-testamento e memória-trabalho; do ponto de vista político, os sentidos de memória subterrânea ou dos vencidos, memória-enquadramento, memória-arquivo. As formulações tecidas nos permitem, então, vislumbrar a reflexão sobre "memória-vida" como caminho epistemológico que se abre para a articulação imanente que perspectivamos entre esse conceito e a experiência narrativa.

Iniciamos pela perspectiva fenomenológica. No movimento da memória, olhamos o passado e encontramos faíscas, lampejos, fragmentos que se articulam e compõem o sentido de nossa trajetória de vida, de determinadas etapas ou acontecimentos. A memória é, assim, seletiva e apresenta-se como filtro. Podemos, então, falar da memória-fragmento, pois o que encontramos são pistas que se articulam numa, sempre plural, construção de sentidos. Nessa direção, Pollak (1989, p. 8) fala da memória como esquecimento e silêncio, advertindo sobre a presença e a função do "não dito" nos relatos orais. Em pesquisas realizadas com pessoas marcadas pela dor e pelo sofrimento, o autor percebe a criação de zonas de sombras e silêncios, lembranças proibidas, indizíveis, que são bloqueadas. Observamos, desse modo, que a memória se configura numa dialética que conjuga lembrança e esquecimento.

Todavia, se é seletiva, por que nos lembramos de algumas coisas e silenciamos ou esquecemos outras? Para Halbwachs, o momento que dá significado a um evento e permite que este seja evocado é sua produção e seu sentido coletivo. "É porque, na realidade, nunca estamos sós. Não é necessário que outros homens estejam lá, que se distingam materialmente de nós: porque temos sempre conosco e em nós uma quantidade de pessoas que não se confundem" (Halbwachs, 1990, pp. 26, 33). Há, assim, um fundo comum, uma dimensão intersubjetiva, grupal e é justamente o pertencimento a uma "comunidade afetiva" que permite a construção dos pontos de referência da memória (Halbwachs, 1990). Da mesma forma, com Benjamin (1993), encontramos a força da inscrição na memória no sentido da experiência plena 
que indica dialeticamente a construção coletiva e a transformação no sentido mais pessoal.

A memória como construção, que se dá nas mediações do indivíduo com diferentes grupos de pertencimento, assume, segundo Arendt, a dimensão de memória-testamento:

Seja como for, é a ausência de nome para o tesouro perdido que alude o poeta ao dizer que nossa herança foi deixada sem testamento algum [...] Sem testamento ou, resolvendo a metáfora, sem tradição - que selecione e nomeie, que transmita e preserve, que indique onde se encontram os tesouros e qual o seu valor - parece não haver nenhuma continuidade consciente no tempo, e portanto, humanamente falando, nem passado nem futuro, mas tão somente a sempiterna mudança do mundo e do ciclo biológico das criaturas que nele vivem (1972, p. 31).

Com esse texto metafórico, a autora adverte sobre uma herança sem testamento, uma herança que pode ser perdida, se não houver quem a nomeie, transmita, preserve. A memória apresenta-se, assim, como riqueza que precisa de "testamento", e nós somos convocados a assumir essa herança, escrevendo o testamento, transmitindo-o.

Este pequeno espaço do tempo intemporal no âmago mesmo do tempo, ao contrário do mundo e da cultura que nascemos, não pode ser herdado e recebido do passado, mas apenas indicado; cada nova geração, e na verdade cada ser humano, inserindo-se entre o passado infinito e um futuro infinito, deve descobri-lo e, laboriosamente, pavimentá-lo (Arendt, 1972, p. 40).

Para escrever o testamento, temos, como desafio, constituir sentidos do passado, o que exige um trabalho artesanal e laborioso. Dessa forma, a partir das contribuições de Bosi (1994), afirmamos a memória-trabalho, porque tempo de lembrar é tempo de trabalho, mas também pela exigência de envolvimento e ação propositiva dos sujeitos. Nesse sentido, Pollak (1992, p. 206) analisa o trabalho da memória em si, "cada vez que uma memória está relativamente constituída, ela efetua um trabalho de manutenção, de coerência, de unidade, de continuidade, de organização”. E, assim, exige construção/ 
reconstrução permanente das imagens do passado na construção do presente e de projetos de futuro.

É necessário, entretanto, destacar dimensões da memória que afirmam uma perspectiva política. Em Benjamin (1993), encontramos o sentido de resgate da história dos vencidos, daqueles que tiveram sua versão da história sufocada pela historiografia oficial - são as memórias subterrâneas das quais também nos fala Pollak (1989, p. 4): "Ao privilegiar a análise dos excluídos, dos marginalizados e das minorias, a história oral ressaltou a importância de memórias subterrâneas, que, como parte integrante, se opõem à 'memória oficial' [...]". A memória como conceito político sinaliza uma abordagem militante na escuta de outras vozes, trazendo a perspectiva de negociação, disputa e conflito.

No contexto desses movimentos de luta, a memória-enquadramento propõe a reinterpretação do passado, em função de combates do presente e do futuro, ressaltando a versão oficial. "Além de uma produção de discursos organizados em torno de acontecimentos e de grandes personagens, os rastros desse trabalho de enquadramento são os objectos materiais: monumentos, museus, bibliotecas etc. A memória é assim guardada e solidificada nas pedras" (Pollak, 1989, p. 9). Solidifica-se nas pedras e impóe-se como versão hegemônica. Entretanto, a dinâmica social viva indica processos de resistência, e formas instituintes de registro convivem com o instituído.

Ainda na perspectiva política, o enquadramento alia-se ao sentido de memória-arquivo, e a análise dessa dimensão nos ajuda a perspectivar as dinâmicas instituintes da "memória-vida" e suas relaçōes com a experiência e a narração. Nora (1993), no texto "Entre memória e história: a problemática dos lugares", discute o processo que levou à consagração dos lugares de memória, a partir dos conceitos de aceleração da história e da própria fratura entre história e memória. Segundo o autor, a falência da memória como pulsão viva da comunidade, a falência da experiência coletiva e da narração, levam à constituição dos lugares da memória, nos quais a história "enquadrada" vai ser perpetuada.

A “aceleração" traz o sentido de movimento, rapidez, e é esse o mesmo sentido que apreendemos da expressão "aceleração da história" no texto citado. É o presenteísmo que vem como marca da sociedade contemporânea: o presente longe do passado e do futuro. Confrontamo-nos com a vivência de uma dimensão do tempo que impõe aos sujeitos um ritmo frenético, ritmo 
que, segundo Benjamin (1993), dificulta as experiências plenas e instituintes. A “aceleração da história” é o sepultamento do passado, do calor da tradição, a vivência do mutismo do costume (Nora, 1993, p. 7).

Nora cita como marco do fim da sociedade-memória e da instauração da "aceleração" o apogeu da industrialização; o declínio da vida camponesa e o instaurar do processo de mundialização, massificação e mediatização. "[...] É o modo mesmo da percepção histórica que, com a ajuda da mídia, dilatou-se prodigiosamente, substituindo uma memória voltada para a herança de sua própria intimidade pela película efêmera da atualidade" (1993, p. 8).

É nesse contexto que surge, segundo o autor, uma ênfase/curiosidade por lugares em que a memória se refugia, cristaliza-se, justamente quando se encontra esfacelada pela consciência da ruptura com o passado. Assim, a aceleração, como um "mal-estar" contemporâneo, articula-se tanto à efervescência da memória-arquivo quanto ao apagamento da dimensão memória-vida. Como contraponto, a memória-vida manifesta sua inteligibilidade na indissociabilidade que apresenta em relação à experiência e à narração, ou, como diremos no prosseguimento da análise, à experiência narrativa. E o que é a experiência? Como memória, experiência e narração se entrelaçam? Essas questôes nos acompanham em estudos anteriores e encontramos, na reflexão citada a seguir, um importante momento de síntese:

Como definir o conceito de 'experiência instituinte'? Essa reflexão nos leva ao encontro das contribuiçōes de Walter Benjamin (1993), para o sentido das 'experiências plenas', que se traduzem por uma tessitura coletiva e pela possibilidade de abertura polifônica. A experiência instituinte se afirma como uma experiência comum, partilhada por um grupo, contrapondo-se, dessa forma, à vivência pontual e fragmentada do sujeito isolado de seus pares. É uma experiência aberta, não se afirma como 'símbolo', com um significado unilateral, mas como 'alegoria', por seus múltiplos sentidos e leituras. Podemos ainda articular esse conceito ao sentido de 'origem' em Benjamin, pois o instituinte, na perspectiva de nossa pesquisa, não se confunde com o 'novo', mas, sim, é uma busca constante do movimento emancipador, movimento este que articula passado, presente e futuro. Contrapondo-se ao modismo e a uma reprodução estática do passado, a experiência instituinte sinaliza a densidade da experiência humana ao rememorar, recuperando, assim, o sentido de uma memória viva, pulsante, onde o olhar para o passado potencializa o 
presente e nos ajuda na construção dos projetos de futuro, pois é ancorada em uma memória que é capaz de prometer (Bragança, 2003).

Tomando referência em Benjamin (1993), encontramos uma contraposição entre vivência e experiência: enquanto a vivência é pontual e efêmera, a experiência é o que nos mobiliza, nos toca, nos afeta e que, portanto, tem um potencial transformador, traz a força do coletivo, da participação do outro e tem a marca de uma abertura polifônica por seus múltiplos sentidos e leituras. Analisando o conceito de experiência, Bondía desenvolve uma linda reflexão e cita Heidegger:

[...] fazer uma experiência com algo significa que algo nos acontece, nos alcança; que se apodera de nós, que nos tomba e nos transforma. Quando falamos em 'fazer' uma experiência, isso não significa precisamente que nós a façamos acontecer, 'fazer' significa aqui: sofrer, padecer, tomar o que nos alcança receptivamente, aceitar, à medida que nos submetemos a algo. Fazer uma experiência quer dizer, portanto, deixar-nos abordar em nós próprios pelo que nos interpela, entrando e submetendo-nos a isso. Podemos ser assim transformados por tais experiências, de um dia para o outro ou no transcurso do tempo (Heidegger apud Bondía, 2002, p. 25).

São as experiências formadoras, na força do que nos atinge, que nos sobrevêm, nos derrubam e transformam, inscritas na memória, que retornam pela narrativa, não como descrição, mas como recriação, reconstrução. Assim, "a experiência que passa de pessoa em pessoa é a fonte a que recorreram todos os narradores" (Benjamin, 1993, p. 198); ou seja, a experiência é a fonte da narração e dos narradores. $\mathrm{O}$ narrador retira da experiência o que conta e, por outro lado, incorpora sua narração à experiência dos ouvintes, como "a mão do oleiro na argila” (Benjamin, 1993, p. 205).

A narrativa, que durante tanto tempo floresceu num meio de artesão - no campo, no mar e na cidade -, é ela própria, num certo sentido, uma forma artesanal de comunicação. Ela não está interessada em transmitir o 'puro em si' da coisa narrada como uma informação ou um relatório. Ela mergulha a coisa na vida do narrador para em seguida retirá-la dele. Assim se imprime 
na narrativa a marca do narrador, como a mão do oleiro na argila do vaso (Benjamin, 1993, p. 205).

Na imagem metafórica do oleiro e do barro, somos confrontados com a impossibilidade de separação entre memória, experiência e narração e vislumbramos o sentido de memória-vida. A experiência instituinte, fruto da intensidade da dinâmica coletiva, encontra-se presente na vida do narrador, que a inscreve na memória, transformando-a no movimento criador da narrativa. $\mathrm{O}$ vaso traz as marcas do oleiro; a experiência narrativa deixa suas marcas não só no resultado material da narrativa que se traduz em linguagem falada, escrita ou documentada, mas também no próprio narrador que se forma e se transforma.

Nesse movimento, buscamos até aqui explicitar um círculo "virtuoso" que oferece indícios para a compreensão dos processos formativos que se dão por meio da experiência narrativa. Considerando a centralidade desse conceito na presente pesquisa, buscaremos, a seguir, um enfoque que, partindo das contribuições de Ricoeur (1994), situe a especificidade desse processo enquanto "tessitura da intriga", bem como as articulações entre tempo e narrativa.

\section{A narrativa como tessitura da intriga: contribuiçôes de Ricoeur}

[...] existe entre a atividade de narrar uma história e o caráter temporal da experiência humana uma correlação que não é puramente acidental, mas apresenta uma forma de necessidade transcultural. $\mathrm{Ou}$, em outras palavras: que o tempo torna-se tempo humano na medida em que é articulado de um modo narrativo, e que a narrativa atinge seu pleno significado quando se torna uma condição da existência temporal (Ricouer, 1994, p. 85).

Em Ricoeur, vemos uma análise profícua da articulação indissociável entre tempo e narrativa. $\mathrm{O}$ autor retoma duas obras clássicas da história da filosofia - as Confissóes, de Santo Agostinho, e A poética, de Aristóteles - e, a partir delas, aprofunda os conceitos de tempo e a narrativa: em Santo Agostinho, o questionamento do tempo, sem uma preocupação explícita com a estrutura narrativa de suas Confissões autobiográficas; em Aristóteles, a teoria da intriga dramática sem consideração sobre a importância da dimensão temporal. Partindo de obras situadas em contextos tão diferenciados, o autor 
alinhava, a pouco e pouco, o sentido de entrelaçamentos que indicam que o tempo se torna humano pela narrativa, e, por outro lado, a narrativa atinge sua plenitude como condição da existência temporal.

Com Agostinho, Ricoeur nos proporciona o mergulho na reflexão filosófica sobre as "aporias da experiência do tempo" (Ricouer, 1994, p. 23). O filósofo traz a perspectiva da eternidade como indicativo e limite da fragilidade ontológica do tempo humano, "[...] como o tempo pode ser, se o passado não é mais, se o futuro não é ainda e se o presente nem sempre é?” (Ricouer, 1994, p. 23). As dúvidas cépticas, entretanto, o levam a afirmação da possibilidade do tempo por meio da tese do tríplice presente, na qual coloca o passado e o futuro, no presente, por meio da memória e da espera.

Narração, diremos, implica memória, e previsão implica espera. Ora, o que é recordar? É ter uma imagem do passado. Como é possível? Porque essa imagem é uma impressão deixada pelos acontecimentos e que permanece fixada no espírito. [...] A espera é assim análoga à memória. Consiste em uma imagem que já existe no sentido de que precede o evento que ainda não é [...] (Ricouer, 1994, p. 27).

Nas palavras de Santo Agostinho, “o presente do passado é a memória, o presente do presente é a visão, o presente do futuro é a espera” (Ricouer, 1994, p. 28). Dessa forma, delineia a compreensão ontológica do tempo humano e situa, no sujeito, a possibilidade da experiência temporal e até da própria medida do tempo, já que a espera do futuro e a memória do passado estão na "alma" como imagens-impressões e imagens-signos. Impressões que só estão presentes na ação do sujeito que espera, está atento e recorda-se (Ricouer, 1994, pp. 37-9).

Podemos estabelecer relaçôes entre a tese do tríplice presente de Santo Agostinho, o tempo de agora em Benjamin (1993) e a imagem do tempo como luta, proposto na metáfora analisada por Arendt (1972). Benjamin propõe um olhar sobre a história, o "tempo de agora", marcado por intensidade e brevidade, em que as questôes do presente nos mobilizam a construir uma experiência com o passado, reconstruindo-o. Faz, dessa forma, uma crítica à epistemologia em sua maneira de compreender a história, por meio de concepçôes de um tempo "homogêneo e vazio", "cronológico e linear". O passado relampeja como imagens de "momentos de perigo" e leva o histo- 
riador a construir uma experiência com esse passado. Como o anjo da história de Paul Klee, que, ao mesmo tempo que olha fixamente para trás, é arremessado para frente, olhamos para o passado porque existem lutas, que foram vencidas e traduzidas pela versão da história oficial. Essas lutas precisam ser recontadas, e o desafio que se coloca é recontar a "contrapelo" a história dos vencidos (Benjamin, 1993, p. 226).

Na parábola de Kafka tomada por Arendt (1972, p. 33), encontramos também uma metáfora que nos remete a uma nova concepção de tempo. "Ele tem dois adversários: o primeiro acossa-o por trás, da origem. O segundo bloqueia-lhe o caminho à frente. Ele luta com ambos [...]." A imagem quebra o sentido de uma passagem linear entre passado e futuro, substitui essa concepção de história linear pela história como movimento de luta vivida pelo sujeito que dá sentido ao processo de construção histórica.

Nas análises, encontramos a força do tempo presente como experiência existencial do sujeito que congrega a potência do passado e do futuro no movimento de ação e de luta dos sujeitos históricos. O tempo torna-se inteligível no sujeito, traduz-se como uma experiência pessoal, assumindo materialidade na narrativa que interage com o passado pela memória e com o futuro pela previsão.

Após o mergulho sobre a temporalidade, a partir de Santo Agostinho, Ricoeur analisa os caminhos da narrativa, em $A$ poética, de Aristóteles. Segundo sua análise, dois conceitos, expressos na referida obra, se articulam tessitura da intriga e atividade mimética. A poética é identificada como arte de compor intrigas, e a atividade mimética, como processo ativo e dinâmico de imitar ou representar. Se, em Platão, mimese apresenta o sentido de cópia, em Aristóteles consiste em produção, poièsis - "a imitação ou a representação é uma atividade mimética enquanto produz algo, a saber, precisamente a disposição dos fatos pela tessitura da intriga” (Ricouer, 1994, p. 60). Logo, Ricoeur toma o modelo de tessitura da intriga de Aristóteles como caminho de compreensão da narrativa.

E o que é a intriga para Aristóteles? $\mathrm{Na}$ análise desse conceito, Ricoeur (1994, p. 70) identifica, no referido autor, a oposição-chave entre sequência episódica e intriga: "Uma depois da outra é a sequência episódica e, pois, o inverossímil; uma por causa da outra é o encadeamento causal e, pois, o verossímil”. Encontramos nas palavras de Aristóteles a seguinte definição: "Chamo de intriga com episódios aquela em que os episódios se seguem (e 
não se encadeiam) sem verossimilhança nem necessidade" (apud Ricouer, 1994, p. 70). A intriga se expressa como uma construção ordenada, coerente, universalizante. "Seu fazer seria globalmente um fazer universalizante. Todo problema do Verstehen narrativo está contido em germe aqui. Compor a intriga já é fazer surgir o inteligível do acidental, o universal do singular, o necessário ou o verossímil do episódico" (Aristóteles apud Ricouer, 1994, p. 70). A narração como tessitura da intriga consiste na composição de tramas que se articulam de forma coerente. Entretanto, essa coerência não está dada, é fruto de construção do sujeito, de ação ou poièsis que vai fazendo surgir, a pouco e pouco, o inteligível, o universal e o verossímil.

Dessa forma, como poièsis, a mimese coloca-se não como cópia do real preexistente, mas como imaginação criadora, abrindo possibilidade para ficção. Tomando a interpretação da $A$ poética, Ricoeur analisa três momentos da mimese para explicitar as relaçôes entre tempo e narrativa, articulando, na tessitura da intriga, um movimento que passa pela ação humana, por sua recriação na composição narrativa e, ainda, pela reconfiguração que se dá na leitura. Assim, o autor procura "mostrar o papel mediador desse tempo da tessitura da intriga entre os aspectos temporais prefigurados no campo prático e a refiguração da nossa experiência temporal por esse tempo construído" (Ricouer, 1994, p. 87).

$\mathrm{Na}$ explicitação dos três movimentos da mimese, entendida como imaginação criadora, tomamos contacto com o processo pelo qual a narrativa, como tessitura da intriga, comporta a densa temporalidade do tríplice presente. Focalizaremos, então, a seguir, esses movimentos. Vejamos o que diz Ricoeur acerca da mimese I:

Imitar ou representar a ação é, primeiro, pré-compreender o que ocorre com o agir humano: com sua semântica, com sua simbólica, com sua temporalidade. É sobre essa pré-compreensão, comum ao poeta e a seu leitor, que se ergue a tessitura da intriga e, com ela, a mimética textual e literária (1994, p. 101).

Mimese I coloca-se na pré-compreensão do mundo e da ação, em suas estruturas inteligíveis e em sua simbologia e temporalidade. Assim, compreender uma história é penetrar no universo do fazer humano e na tradição cultural em que se encontra imersa a intriga. Ricoeur fala de um simbolismo imanente que, sendo um processo cultural, articula a experiência em sua in- 
teireza - "um sistema simbólico fornece, assim, um contexto de descrição para ações particulares”. Esse universo cultural e simbólico contextualiza a ação particular, que vem marcada pelo sentido temporal que se coloca de forma implícita na ação, e pode ser considerado indutor da narrativa (1994, pp. 93, 95).

A Mimese II faz a mediação entre a ação e a narrativa, apresentando um carácter dinâmico de configuração, de tessitura da intriga. Tal mediação apresenta três sentidos. Em primeiro lugar, trata-se de uma mediação entre o singular e o geral, "entre acontecimentos ou incidentes individuais e uma história considerada como um todo", transformando "acontecimentos e incidentes em uma história” (Ricouer, 1994, p. 103). Uma história que, segundo Ricoeur, não se coloca como uma enumeração de acontecimentos, mas numa "totalidade inteligível em torno de um tema, ou seja, a tessitura é a operação que extrai de uma simples sucessão uma configuração” (1994, p. 104). Em segundo lugar, a tessitura da intriga efetiva mediação entre fatores diversos, como "agentes, fins, meios, interações, circunstâncias e resultados inesperados etc.” (1994, p. 104). Mas a intriga é mediadora também por apresentar caracteres temporais próprios, ligados à dinâmica da configuração narrativa, apresentando-se como "síntese do heterogéneo" (1994, p. 104). Do ponto de vista temporal, a tessitura da intriga apresenta uma dimensão cronológica e uma não cronológica: a primeira manifesta-se na perspectiva episódica da narrativa, ou seja, é constituída de acontecimentos que se sucedem; a segunda traz o potencial de subverter o tempo linear no movimento que transforma acontecimentos em história, num ato configurante dos incidentes da história.

A conjugação dessas diferentes instâncias mediadoras produz a possibilidade de que uma história possa ser seguida, compreendida. "Seguir uma história é avançar no meio de contingências e de peripécias sob a conduta de uma espera que encontra sua realização na conclusão" (Ricouer, 1994, p. 102). A conclusão apresenta um ponto de vista que permite que a história seja compreendida em seu todo, que dá sentido à sucessão de episódios que conduziram à conclusão, não que esta seja previsível, mas aceitável, isto é, "congruente com os episódios reunidos" (Ricouer, 1994, p. 102). A configuração dá sentido aos incidentes e à conclusão, e o processo de configuração, que traduz o sentido de tessitura da intriga, aproxima-se da imaginação produtora, assim com a Mimese II somos colocados no campo da ficção (Ricouer, 1994, pp. 102, 105-6). 
A Mimese III faz a passagem entre "o mundo do texto e o mundo do ouvinte ou do leitor" (Ricouer, 1994). A narrativa oral e a leitura favorecem a transposição entre Mimese II e III, e nessa passagem a história se reatualiza, se refigura. Por meio da leitura, o texto comunica sentidos e referências, sentidos atribuídos pelo autor, mas referências à materialidade da ação que refigura e atualiza.

[...] o que é interpretado num texto é a proposta de um mundo que eu poderia habitar e no qual poderia projetar meus poderes mais próprios. A poesia, por seu muthos, descreve o mundo. Da mesma maneira, direi nesta obra que o fazer narrativo re-significa o mundo na sua dimensão temporal, na medida em que contar, recitar, é refazer a ação segundo o convite do poema (Ricouer, 1994, p. 123).

O círculo virtuoso da mimese é aberto, é um convite à interpretação das ações humanas que se coloca em todas as suas dimensões, na pré-compreensão da ação, na produção narrativa e na leitura. Todo processo mimético é guiado pela imaginação criadora, já que o passado só pode ser reconstruído pelo sujeito por meio de vestígios e na intensidade da experiência temporal.

\section{Formação, aprendizagem experiencial e processos identitários}

A partir da revisão de literatura desenvolvida no capítulo 2, tematizamos sentidos da formação como movimento de transformação pessoal, ou seja, enquanto os processos educativos constituem práticas sociais, a formação é interior e se liga à experiência do sujeito que se permite transformar pelo conhecimento. $\mathrm{O}$ estar no mundo, com as pessoas e a natureza, vai abrindo caminhos para uma transformação e ao mesmo tempo se projeta nas relaçōes do sujeito, numa dialética entre o "eu" e o "nós". A definição dessa perspectiva nos leva ao encontro de questôes: como relacionar, no contexto da abordagem (auto)biográfica, formação e aprendizagem experiencial? Quais são as mediações entre formação e processos identitários?

Enquanto a formação se coloca como um processo global, constituído ao longo da trajetória de vida, envolvendo uma complexidade de dimensões, as aprendizagens experienciais situam-se na particularidade dessas dimensões; são, pois, as transformações que dão capilaridade à vida e que, articuladas, 
produzem formação. Segundo Josso (2002a), uma aprendizagem ancorada na experiência, que articula saber-fazer e conhecimento, teorias e práticas, funcionalidade e significação, técnicas e valores. Nesse sentido, podemos inclusive retomar o conceito de práxis como ação refletida e propositiva sobre o mundo. A aprendizagem experiencial, proposta pela abordagem (auto) biográfica, implica três dimensões existenciais: o conhecimento sobre si; o conhecimento sobre seu fazer, sua prática; e a reflexão crítica sobre suas próprias concepçóes, traduzindo-se em uma atitude filosófica frente à vida.

A formação, em sua dimensão pessoal e interior, leva-nos ao encontro das mediações entre esse conceito e os processos identitários. O sentido da identidade do ser traduz uma questão que apresenta longa trajetória na história da filosofia. Uma postura essencialista que perspectiva a identidade fixa em contraste com a dialética que olha a vida como movimento e devir e, nesse sentido, uma identidade em permanente construção. A primeira visão de mundo assume hegemonia na história da filosofia, entretanto, o sentido da vida como vir a ser ocupou brechas e deixou suas marcas instituintes.

Os trabalhos que discutem os processos identitários tomam como referencial de análise abordagens centradas especialmente na sociologia, na psicologia, na filosofia e, a partir de diferentes perspectivas, reatualizam-se em uma pluralidade de caminhos teóricos e epistemológicos.

Analisando as relações entre memória e identidade social, Pollak (1992) busca o sentido de identidade como "imagem de si, para si e para os outros". Ao longo da vida, o sujeito histórico constrói uma imagem sobre si próprio que é apresentada a si e aos outros como sua representação, mas também como indicativo da forma pela qual deseja ser percebido pelos outros. A identidade apresenta, assim, uma perspectiva pessoal, social e, ainda, situada em contexto, podendo ser analisada nessas três dimensōes: a identidade pessoal ou identidade para si, que coincide com o self e apresenta uma organização relativamente durável, relaciona-se ao modo como a pessoa vê a si própria, considerando sua biografia e projetos de futuro; a identidade social ou identidade para o outro é relativa aos diversos papéis que cada um vive ao longo de sua trajetória de vida e à forma como é percebido pelos outros com os quais interage; e a identidade situada diz respeito à organização entre identidade pessoal e identidade social e dada situação (Ponte e Oliveira, 2002; Lopes, 2001a).

Mas como se dá a construção dessa imagem de si e para os outros? Dubar (1996) analisa esse processo por meio da socialização primária e secundá- 
ria, processo plural que apresenta as marcas da interação com a vida coletiva. A socialização liga, assim, o sujeito aos diferentes contextos dos quais faz parte, implicando integração e adaptação ao sistema. Considerando que o social é permeado de contradições e dualidades, também a identidade do sujeito não é harmoniosa, mas aponta uma constante busca de equilíbrio entre processos plurais, estando em permanente reconstrução. A socialização primária se dá na infância, tendo, como agentes fundamentais, a família e a escola; a socialização secundária, na adolescência e na vida adulta pelo contato com os mais diferentes grupos e instituiçóes, pela imersão no mundo vivido, na experiência de vida e profissional. Assim, na vida adulta, ressalta-se a importância da experiência no mundo do trabalho como geradora da identidade profissional, situada como uma das identidades sociais em que os saberes profissionais assumem relevância nas lógicas de reconhecimento e de afirmação da imagem para si e para os outros (Fusulier e Maroy, 1996, p. 120; Ponte e Oliveira, 2002, p. 150; Lopes e Ribeiro, 2000b, p. 44; Courtois, 1995, p. 44).

Relacionando o processo identitário à socialização, segundo Dubar, nas ciências humanas e sociais, o termo identidade indica não a natureza profunda do indivíduo ou um coletivo em si, mas a relação entre o coletivo e o indivíduo:

Assim, as identidades colectivas e individuais são inseparáveis, a questão é geralmente de saber como tal comportamento, crença ou atitude [...] pode se compreender a partir dos pertencimentos colectivos ou da maneira como são vividos ou traduzidos, interiorizados pela pessoa (1996, p. 38).

Essa perspectiva teórica ancora-se no sentido de identidade como movimento e reconstrução permanente, considerada "um resultado provisório de transacção biográfica entre 'identidade herdada' e 'identidade visada' e a transacção relacional entre 'identidade para o outro' e 'identidade para si'” (Fusulier e Maroy, 1996, p. 121). São as mediações entre a memória da trajetória passada e o desejo de projetos de futuro e entre o "eu" e os muitos "outros" que favorecem a tessitura, pelo sujeito, de uma imagem de si. Nesse sentido, Dubar (1996, p. 43) afirma que cada um pode passar de uma forma identitária a outra, o que chama de conversão identitária, assim como combinar várias formas identitárias segundo os contextos. Essas transformações permitem, segundo Lopes (2002a, p. 47), a conservação de parte da identida- 
de antiga, ao mesmo tempo que incorpora significados novos; continuidade e transformação se entrelaçam dialeticamente.

Voltando ao questionamento inicial: como articular o sentido de formação, anteriormente explicitado, ao processo identitário? Segundo Courtois (1995), a formação experiencial alimenta a dinâmica da transformação identitária. A formação ancorada nas aprendizagens experienciais não consiste em uma acumulação de informações e saberes, mas na experiência vital do sujeito que se transforma juntamente com o conhecimento, assumindo novas formas de ser e de estar no mundo, e, juntamente com essas novas formas, as imagens de si, para si e para o outro são ressignificadas. Nessa perspectiva de análise, formação e processo identitário se encontram e constituem um campo de interseção na transformação do sujeito, mas se distinguem, sendo a primeira processo de conhecimento vital em movimento e a segunda, o reflexo provisório desse processo. A identidade, assim, afirma-se como a imagem refletida no espelho vista pelo próprio sujeito e pelos outros; e a formação, como o que se processa internamente e permite a configuração provisória que se reflete.

$\mathrm{Na}$ pesquisa desenvolvida por Flores com professores em início de carreira, encontramos expressão da sutileza das interfaces e distinções entre as referidas dinâmicas:

[...] o processo de mudança das atitudes e práticas dos professores é complexo e depende da interaç̧ão de factores idiossincráticos e contextuais. A confrontação com a (inesperada) complexidade do ensino e com as dinâmicas da escola e da sala de aula levou os professores a revisitarem, a quetionarem e a (re)enquadrarem suas crenças (iniciais) e suas imagens sobre o ensino e sobre o que significa ser professor e, consequentemente, a uma (re)definição da sua identidade profissional (2004, p. 115).

$\mathrm{Na}$ análise da autora, o revisitar das crenças e imagens sobre o ensino em uma mediação entre saberes construídos na formação inicial e a realidade concreta da prática educativa - revela um processo de conhecimento vital e de transformação de concepções e práticas, trazendo, consequentemente, uma nova imagem sobre a docência para si e para os outros, ou seja, a recriação da identidade profissional.

Mas nessa tessitura de relaçóes ainda é importante trazer os fios da memória e da narração. Analisando o processo de construção da identidade, 
Pollak (1992) destaca, a partir da psicologia social e da psicanálise, três elementos: "o sentimento de ter fronteiras físicas, no caso do corpo da pessoa, ou fronteiras de pertencimento ao grupo, no caso de um coletivo"; a continuidade no tempo; e o sentimento de coerência entre diferentes dimensões do próprio sujeito. Nesse sentido, observa-se que a ruptura dos sentimentos de unidade e continuidade pode provocar, inclusive, alterações patológicas. Nas citações seguintes, encontramos pistas sobre a importância da memória e da narrativa das histórias de vida no fortalecimento desses sentimentos de unidade e coerência.

Podemos portanto dizer que a memória é um elemento constituinte da identidade, tanto individual como coletiva, na medida em que ela é também um fator extremamente importante do sentimento de continuidade e de coerência de uma pessoa ou de um grupo em sua reconstrução de si (Pollak, 1992, p. 204).

O desenvolvimento identitário do professor realiza-se na procura de uma coerência temporal, na construção narrativa de histórias de vida que deem coesão ao passado, ao presente e aos seus futuros antecipados (Sanches, 2002, p. 92).

O olhar para o passado e a narrativa desse passado favorecem a busca de coerência, fortalecendo o sentimento de continuidade e de unidade. A identidade consiste também em uma narrativa de si, a qual se constrói a partir de imagens do passado e de projetos de futuro que se abrem, entre "identidade herdada" e "identidade visada". E uma das contribuições da abordagem (auto)biográfica, em contexto de formação de professores/as, coloca-se justamente no sentido ontológico de construção de si, em um movimento de formação que articula memória, narração e reconstrução identitária (Bragança, 2008).

\section{Abordagem metodológica}

Buscamos, com a "abordagem metodológica”, relações internas entre o teórico e o metodológico que se desenham na experiência da pesquisa (auto) biográfica no campo educativo e, especialmente, na formação de professores/ as. Procuramos, desse modo, indicar e justificar o caminho proposto por 
este livro, na perspectiva da investigação-formação, por meio de narrativas de formação. Além disso, em uma reflexão sobre as propostas de caminhos, incluímos uma análise dos desafios da interpretação, considerando o lugar e a importância dessas dimensões neste estudo.

\section{Pesquisa-ação, pesquisa-formação e as especificidades da biografia educativa}

A abordagem das histórias de vida rompe, por sua própria natureza, com a prática simplificadora, reducionista e nomotética da investigação social, projetando a pesquisa em educação fora do quadro lógico-formal. É esse movimento de ruptura que, segundo Ferrarotti, modifica as bases da pesquisa, transformando-a em pesquisa-participação: "De la sociologie comme parti pris de neutralité et pratique administrative socialement neutre, on passe à la sociologie comme participation humaine significative et moyen d'autodéveloppement" (1990, pp. 89-90). Nesse sentido, a pesquisa-formação coloca-se como um paradigma metodológico que procura romper com a neutralidade e objetividade das práticas de pesquisa, aproximando investigadores e participantes da dinâmica viva do conhecimento.

A pesquisa-formação tem sua origem na pesquisa-ação, já que busca um efetivo envolvimento dos pesquisadores na transformação individual e coletiva. Essa perspectiva encontra fundamentação na dialética histórica, no conceito de práxis, tal como proposto por Marx, que perspectiva uma filosofia que não apenas interprete o mundo, mas possa transformá-lo, por meio de uma relação de imbricação entre prática-teoria-prática.

Além do carácter de ação dialética, de busca de transformação, Josso destaca, como característica dessa proposta metodológica, o sentido de "experiência": a pesquisa-ação e a pesquisa-formação geram uma experiência que apresenta uma natureza específica. Se, no positivismo, encontramos uma separação entre sujeito e objeto, na perspectiva que analisamos, é no movimento intersubjectivo, no encontro e na partilha do processo de investigação, que o conhecimento é produzido e, assim, a pesquisa-formação assenta-se sob uma experiência existencial que produz conscientização (1991, pp. 114-25).

O postulado da pesquisa-formação é, pois, de que a intensidade dessa experiência pode produzir conscientização como processo que não pode ser ensinado, mas que é vivido de maneira muito pessoal pelo sujeito: um movimento que leva à busca de transformação. Essa perspectiva de investigação 
não nega o carácter científico, antes, busca um saber fruto de uma objetivação, apresentando múltiplas dimensões (Josso, 1991).

Em um contexto de interação efetivamente humana, o desenvolvimento do trabalho de investigação produz um movimento de formação, de autodesenvolvimento para o investigador e para os que participam como sujeitos da pesquisa. A pesquisa-formação implica uma experiência significativa de articulação de saberes, não busca a produção de um saber dicotomizado que futuramente "poderá ser aplicado" socialmente, mas o desenvolvimento da pesquisa pressupõe a mobilização de saberes, experiências e praxis vitais. ${ }^{24}$

O desenvolvimento da investigação com aporte nas histórias de vida traz, assim, uma especificidade já anunciada em diferentes momentos: rompe-se a clássica separação entre investigador e participante da pesquisa, entre o que se considera "sujeito" e outro que é considerado "objeto". Na perspectiva que buscamos desenvolver, por meio da presente pesquisa, entendemos que ambos são sujeitos do processo de conhecer, sujeitos que, com papéis diferenciados, colocam-se num movimento de pesquisa e de formação.

O conceito de "biografia educativa" foi formulado por Dominicé, nos anos de 1980, tendo como referência a tradição das histórias de vida na perspectiva sociológica. $\mathrm{O}$ autor experimenta um enfoque centrado na narrativa de formação, diferenciado do que anteriormente foi realizado nas ciências humanas (Josso, 1991, p. 69). Em Learning from our lives: using educational biographies with adults, Dominicé (2000) relata a construção de seu caminho de investigação, que, partindo do trabalho sobre avaliação, encontra na abordagem autobiográfica uma forma de estudar o processo de aprendizagem dos adultos. Seu trabalho foi desenvolvido na Universidade de Genebra, no contexto dos seminários que receberam o título de História de Vida e Formação.

Segundo esse autor, a biografia educativa não é uma autobiografia completa como a história de vida, mas é o relato das experiências que ao longo da vida se constituíram de maneira formadora, trazendo a intensidade de um processo muito pessoal marcado por seu sentido coletivo (Dominicé, 2000, pp. 171, 173).

${ }^{24}$ Pineau (Pineau e Michèle, 1983) apresenta o resultado de um trabalho que vem como investimento no processo de pesquisa-formação por meio da história de vida, no qual Michèle, que participa como sujeito da pesquisa, narra e interpreta seu processo de formação, de autodesenvolvimento. Michèle relata a intensidade desse movimento, que, como operação vital, vai transformando a própria vida e dando sentido a ela. 
Encontramos, assim, no trabalho com as histórias de vida que focaliza os percursos formativos, a compreensão e a análise biográfica desse processo vital: a construção do conhecimento, engendrando transformações pessoais e coletivas nos sujeitos. É no movimento dialético entre passado, presente e futuro que os sujeitos se apropriam da vida como processo formativo e tomam a responsabilidade pela atribuição de sentido e pela ressignificação da trajetória pessoal/profissional. A biografia educativa não coloca, portanto, ênfase no resultado material do processo, ou seja, no texto escrito, mas no movimento reflexivo, que toma como referência a centralidade temporal, potencializadora do presente e do futuro. Assim, biografia educativa transforma a rememoração em formação.

Diante da apresentação do conceito, podemos questionar se há diferenças entre essa abordagem e o que, no Brasil, denominamos de forma mais recorrente como narrativas de formação. Se retomarmos os sentidos de educação e de formação, tal como anteriormente discutimos, encontraremos nas terminologias utilizadas uma diferenciação importante, pois o "educativo" estaria vinculado aos processos, e o "formativo", às transformaçōes do sujeito aprendente. Entretanto, a análise do conceito tal como utilizado por Dominicé não permite essa diferenciação, pois fala da "biografia educativa" não no sentido de um recorte estrito sobre a escolarização ou sobre processos externos aos quais o narrador foi submetido, mas sobre a forma como esses processos mobilizaram o movimento formativo, na intensidade das dinâmicas individuais e coletivas. Todavia, como já referido, observamos que a abordagem das "biografias educativas" tem sido denominada especialmente como "narrativas de formação", conforme explicita Souza:

[...] entendo que a abordagem biográfica e a autobiografia das trajetórias de escolarização e formação tomadas como narrativas de formação inscrevem-se nesta abordagem epistemológica e metodológica, por compreendê-la como processo formativo e autoformativo, através das experiências dos atores em formação. Também porque esta abordagem constitui estratégia adequada e fértil para ampliar a compreensão do mundo escolar e de práticas culturais do cotidiano dos sujeitos em processo de formação (2004, p. 5).

Entendemos, assim, que a expressão "narrativas de formação" afirma-se justamente por anunciar em sua própria denominação a "formação" 
como marca que identifica a utilização metodológica das histórias de vida no campo educativo. Nesse sentido, a referida expressão coloca-se, além da investigação, como possibilidade efetiva de que o processo narrativo constitua uma experiência instituinte de novos saberes e práticas.

Podemos, ainda, trazer a discussão do recorte temporal que se coloca nesse desdobramento metodológico. Josso (2002a) distingue a utilização da abordagem (auto)biográfica no campo educativo entre o trabalho com as histórias de vida, com enfoque na globalidade temporal, e a perspectiva de trabalho por projetos, com característica temática sobre determinado itinerário. Por outro lado, Dominicé (2000), quando define as biografias educativas, faz justamente uma contraposição no sentido de que não constituem uma história de vida completa do sujeito, mas o enfoque sobre os processos formativos que se dão ao longo da vida. Nesse sentido, seriam as biografias educativas ou narrativas de formação colocadas como trabalho na perspectiva de projeto por trazerem a formação como eixo temático? Porém, se entendemos a formação como um processo que se dá ao longo de toda a trajetória de vida dos sujeitos, a reconstrução do mesmo, por meio da narrativa, não nos levaria justamente à globalidade da vida em suas diferentes dimensões? Entendemos que o recorte temporal, no caso das biografias educativas ou narrativas de formação, deve colocar-se de acordo com os objetivos da investigação, podendo estar, assim, próximo à compreensão de história de vida como perspectiva globalizadora e apresentar-se com um recorte temporal dado pelo narrador ou pela natureza da investigação.

Neste livro, apresentamos as biografias educativas das professoras como narrativas abertas da tessitura da formação que se dá ao longo da trajetória de vida e, portanto, em uma perspectiva de temporalidade alargada que as liga ao sentido das histórias de vida no campo das ciências sociais e humanas.

\section{Desafios da interpretação hermenêutica}

A opção metodológica, anteriormente referida, coloca-nos frente ao desafio de trilhar os caminhos da interpretação hermenêutica. Narrativas de formação, orais e escritas, constituem, como vimos, uma tessitura de intrigas; trazem a força da linguagem humana e da reconstrução pessoal/coletiva como processo essencialmente formador, por suas potencialidades transformadoras. A narração é prenhe de significados para quem narra, para quem 
escreve, para quem lê; assim, a narrativa por si só é inteligível, se não o for, não constitui uma narrativa; é um convite ao diálogo e, portanto, à interpretação partilhada do sujeito com ele próprio e com os outros. Consideramos nessa afirmação uma das dimensões da interpretação que queremos ressaltar neste estudo: as narrativas falam por si de forma polifônica, como "metáforas vivas" (Ricouer, 1996), que não se deixam aprisionar.

As narrativas de formação, entretanto, no contexto da investigação no campo das ciências da educação, podem, além de sua expressão de sentidos, ser analisadas em função do objeto de estudo pretendido, dos objetivos e das questôes propostas, que, no caso deste livro, consistem na própria tessitura da formação como processo narrativo que se dá na articulação de diferentes tempos, espaços e dimensôes da vida. Assim, buscaremos explicitar indicativos sobre a interpretação hermenêutica que tomamos como base na análise das entrevistas biográficas realizadas, tendo em vista os objetivos deste estudo: que perspectivas se apresentam como possibilidades de análise das narrativas? Em que consiste o processo de atribuição de sentidos e quais as possibilidades sinalizadas pela hermenêutica?

No que se refere aos caminhos da interpretação, Azzan (1993) analisa duas perspectivas antropológicas: a estrutural e a interpretativa. Enquanto a primeira procura explicar por meio do método estrutural a infraestrutura do processo de significação em uma dicotomia entre código e mensagem, a segunda busca o sentido como manifestação da vida social inerente à atuação do sujeito no mundo.

No paradigma interpretativo, o sentido é uma conjugação de subjetividade, um "encontro de horizontes". Cabe ao leitor refazer o sentido, criar novas referências para a interpretação. $\mathrm{O}$ texto, ao ser interpretado, recria suas referências, atualizando a possibilidade de leitura. Para o paradigma compreensivo, os fenômenos são sempre interpretáveis, e não meramente classificáveis como leis (Azzan, 1993, pp. 18, 22).

Mas essa procura por significados é uma busca pela compreensão do mundo conceitual dos sujeitos. São significados para eles: 'o ponto crucial da abordagem semiótica é, como tenho dito, ajudar-nos a ganhar acesso ao mundo conceptual no qual nossos sujeitos vivem e assim possibilitar-nos, num sentido lato, conversar com ele (Azzan, 1993, p. 95). 
A antropologia interpretativa é, assim, uma abordagem francamente humanística, pois o sujeito é a referência para a interpretação e para a busca do sentido. Nesse paradigma teórico, faz-se opção pelo "modelo textualístico" de cultura, em que o texto se afirma como produto histórico, exprime as possibilidades de encontro dos horizontes do intérprete e do autor; ele é produzido e lido historicamente, é fruto da interação humana (Azzan, 1994, pp. 102-3).

Encontramos pontos comuns entre a filosofia benjaminiana e as contribuições da hermenêutica, especialmente nos conceitos de texto, interpretação e produção histórica e coletiva do sentido. A origem dos trabalhos de Benjamin está na análise de obras literárias que seguiam a lógica burguesa, em um conceito de tempo vazio, homogêneo e linear. Ele traz a intensidade dos textos, exatamente no sentido de resgatar as condições históricas e materiais de sua produção. A interpretação em Benjamin tem referência na Cabala judaica, buscando uma dimensão polissêmica da linguagem que, segundo ele, deteriorou-se e perdeu seu espaço por meio do predomínio do uso "monológico da linguagem tecnocratizada" (Gagnebin, 1993, p. 61). Essa dimensão polissêmica não busca delimitar um sentido unívoco, mas, ao contrário, revela a profundidade ilimitada da palavra. Assim, o texto tem um sentido múltiplo, um sentido para, construído através da experiência partilhada, aberto à possibilidade de um fazer conjunto entre autor e leitor. "Esse conceito enfático de experiência permite, assim, a escritura de uma anti-história, porque, em vez de encerrar o passado numa interpretação definitiva, reafirma a abertura de seu sentido, seu caráter inacabado" (Gagnebin, 1993, p. 61).

Ricoeur (1996, pp. 18, 23), tomando a perspectiva interpretativa, analisa de forma dialética a relação entre narrativa e sua significação, entendendo que o discurso traz um sentido sintético que lhe é inerente, e, assim, indica a passagem da linguística do código para a linguística da mensagem. Destacaremos alguns aspectos da análise desse autor, especialmente o sentido de narrativa como acontecimento e comunicação e sua vinculação com a experiência, bem como as mediações entre os sentidos na narrativa oral e escrita.

A experiência, como vimos anteriormente, tem um carácter pessoal e subjetivo. No ato comunicativo entre narrador e ouvinte, a experiência pode ser partilhada por meio de sua significação. "O evento não é apenas a experiência enquanto expressa e comunicada, mas também a própria troca intersubjectiva, o acontecer do diálogo" (Ricouer, 1996, p. 28). 
A minha experiência não pode tornar-se directamente a vossa experiência. Um acontecimento que pertence a uma corrente de consciência não pode transferir-se como tal para outra corrente de consciência. E, no entanto, algo se passa de mim para vocês, algo se transfere de uma esfera de vida para outra. Este algo não é a experiência enquanto experienciada, mas sua significação. Eis o milagre. A experiência experienciada, como vivida, permanece privada, mas seu sentido, a sua significação torna-se pública. A comunicação, é, deste modo, a superação da radical não comunicabilidade da experiência vivida enquanto vivida (Ricouer, 1996, p. 28).

A narrativa possibilita a expressão da experiência vivida pelo sujeito, ao mesmo tempo que a transforma na comunicação intersubjetiva do diálogo; ao ser dita, a experiência se transforma em seus sentidos. As palavras são polissêmicas, abertas a uma pluralidade de sentidos e é justamente o contexto do discurso, a relação travada entre narrador e ouvinte, que permite que as palavras sejam filtradas, compreendidas (Ricouer, 1996, pp. 28, 38).

E o que acontece no texto escrito, já que a relação entre o narrador e o ouvinte, agora leitor, não se dá de forma direta? Será a escrita apenas fixação do discurso oral? Segundo Ricoeur (1996), a escrita é muito mais do que uma reprodução da fala, "é pensamento humano directamente trazido à escrita sem o estádio intermediário da linguagem falada", "a escrita toma o lugar da fala”. Logo, a natureza diversa entre narrativa oral e escrita nos coloca frente à questão hermenêutica de análise dos sentidos, pois, se no discurso oral a frase carrega a presença do seu narrador, por meio de indícios de sua subjetividade, já que esse está presente na situação de interlocução, no discurso escrito, ao contrário, "a intenção do autor e o significado do texto deixam de coincidir” (Ricouer, 1996, p. 40). A materialidade do texto escrito ou a inscrição material do discurso leva à autonomia semântica do texto que desassocia a intenção original do autor quanto ao significado do texto. Por isso, "o que o texto significa interessa agora mais do que o autor quis dizer quando escreveu" (Ricouer, 1996, p. 41).

Segundo Ricoeur (1996), é importante, entretanto, não cair no equívoco que contrapõe a falácia intencional à falácia do texto absoluto, ou seja, a supervalorização da intenção do autor como critério para significação do texto ou, por outro lado, o isolamento do texto como se não tivesse autor. Propõe, portanto, como ponto de partida, a compreensão dialética em que o 
significado autoral está presente como uma dimensão do texto, em diálogo com os sentidos assumidos pelo próprio texto em sua possibilidade de autonomia (Ricouer, 1996, p. 42).

Outro aspecto relevante na análise da natureza interpretativa da narrativa oral e escrita diz respeito ao público: a narrativa oral dirige-se a um sujeito ou a um coletivo definido pela situação de interlocução, em um contexto de comunicação restrita; já a escrita apresenta um leitor desconhecido e aponta a "universalização do auditório", já que, potencialmente, qualquer leitor pode ter acesso ao texto. A escrita, segundo Ricoeur, traz a plenitude da dialética entre significação e acontecimento, pois afirma-se como universal e contingente - universal no sentido de sua abertura ao conjunto de leitores, mas contingente porque sua universalidade é apenas potencial, pois o texto cria um campo de leitores aos quais o texto é acessível. A plenitude da escrita coloca-se, assim, nomeadamente, por sua abertura a uma multiplicidade de leitores e de interpretações, sendo esta justamente a contrapartida dialética da autonomia do texto. "Segue-se que o problema da apropriação do sentido do texto se torna tão paradoxal como o da autoria. O direito do leitor e o direito do texto convergem numa importante luta, que gera a dinâmica total da interpretação. A hermenêutica começa onde o diálogo acaba” (Ricouer, 1996, pp. 42-3).

Mas as contraposições entre narrativa oral e escrita se colocam também quanto à relação entre sentido e referência. No discurso oral, a referência, ou seja, as entidades extralinguísticas às quais o discurso se refere, como acontecimentos, pessoas, lugares, coisas, estão imediatamente situadas no contexto da comunicação, fazem parte do universo comum partilhado pelos que tecem o diálogo. Essas referências são reforçadas pela linguagem gestual, por expressões, manifestações emotivas e referências ostensivas, como advérbios de tempo, de lugar e outros recursos da linguagem oral. As referências ostensivas continuam presentes no discurso escrito, entretanto, a gama de apelos que envolve a intersubjetividade não se torna tão evidente ou se manifesta de outra forma na relação entre o leitor e o texto (Ricouer, 1996, p. 46).

A ausência de uma situação comum gerada pela distância espacial e temporal entre o escritor e o leitor; o cancelamento do aqui e agora absoluto pela substituição das marcas externas materiais para a voz, a face, o corpo do locutor como a origem absoluta de todos os lugares no espaço e no tempo; e a auto- 
nomia semântica do texto que o separa do presente do escritor e o abre a um âmbito indefinido de leitores potenciais num tempo indeterminado - todas as alterações da constituição temporal do discurso se reflectem em alterações paralelas do carácter ostensivo da referência (Ricouer, 1996, p. 47).

A relação entre o leitor e o texto se assenta, assim, em uma natureza diferenciada da que é estabelecida entre o narrador e o ouvinte, no contexto de uma comunicação direta. O texto ganha autonomia por seu descolamento espaçotemporal e subjetivo, inerente à relação direta da comunicação. $\mathrm{O}$ autor, entretanto, destaca que a autonomia do texto não significa a abolição da referência. Mesmo um texto poético fala do mundo, de um modo de estar no mundo, e, nesse sentido, só a escrita, "ao libertar-se não só do autor e do seu auditório originário, mas da estreiteza da situação dialógica, revela esse destino do discurso como projectando um mundo" (Ricouer, 1996). Tal como a pintura, a escrita ou fixação material do discurso não reduz o original, mas potencializa as possibilidades de interpretação, "a inscrição do discurso é a transcrição do mundo, e transcrição não é reduplicação, mas metamorfose" (Ricouer, 1996). Por outro lado, a leitura resgata a significação do texto do estranhamento e da distanciação, pois o leitor estabelece uma relação também dialógica que abre o caminho para sua transformação (Ricouer, 1996, pp. 49, 52-3).

O sentido de metamorfose produzido pela narrativa escrita, bem como a potencialização de múltiplas interpretações, manifesta-se também na utilização de "metáforas vivas" (Ricouer, 1996, pp. 63-4). A metáfora viva, tal como analisada pelo autor, não consiste na substituição de uma palavra por outra de forma estéril ou colocada como mero ornamento, mas diz algo novo a respeito da realidade - "é a presença inarticulada de um excesso de sentido, cuja dinâmica arranca os significados já construídos de sua situação ordinária e os transfere para um novo campo referencial" (Pereira, 1983, p. 37).

$\mathrm{Na}$ dialética entre narrativa e significação, tanto no discurso oral como no escrito, encontramos ancoragem na abertura à uma polifonia de vozes e de sentidos e somos, então, confrontados com a questão filosófica da verdade. Qual é a possibilidade de a verdade se afirmar em um trabalho científico que toma como referência epistemológica a abordagem (auto)biográfica, considerando tanto a importância da memória e de sua natureza inventiva como os caminhos da interpretação como abertura à pluralidade de sentidos? 
Sabemos que Proust não descreveu em sua obra uma vida como ela de fato foi, e sim uma vida lembrada por quem a viveu [...] Pois o importante, para o autor que rememora, não é o que ele reviveu, mas o tecido de sua rememoração, o trabalho de Penélope da reminiscência. Ou seria preferível falar do trabalho de Penélope do esquecimento? A memória involuntária, de Proust, não está mais próxima do esquecimento que daquilo que em geral chamamos de reminiscência? Não seria esse trabalho de rememoração espontânea, em que a recordação é a trama e o esquecimento, a urdidura [...] (Benjamin, 1993, p. 37).

Benjamin se refere à tessitura da narrativa memorialística, colocando enfoque não no que o autor rememora, mas no tecido de sua rememoração; entretanto, fala de um contexto ligado à obra de ficção. A utilização da perspectiva (auto)biográfica, tanto em pesquisa como em programas de formação, no campo educativo, desafia-nos a pensar uma epistemologia que se afirma como trabalho científico, justamente por incorporar a vida humana e a subjetividade. Ricoeur (1994, p. 134) analisa as relações entre a narrativa ficcional e a narrativa histórica, afirmando "um laço indireto de derivação pelo qual o saber histórico procede da compreensão narrativa sem nada perder de sua ambição científica”, e reconstruir esses laços é trazer à luz a "intencionalidade do pensamento histórico"; a história continua a visar o campo da ação humana e a sua temporalidade de base. $\mathrm{O}$ autor defende que tanto a narrativa de ficção como a histórica trazem em comum a organização por meio da tessitura da intriga, passando pelo círculo mimético que envolve a Mimese I, pela referência à ação humana, a Mimese II, na configuração desse campo por meio da atuação do narrador, e a Mimese III na reconfiguração que se dá pela leitura. Segundo o autor, a realidade histórica é construída pelo historiador por meio de vestígios, em uma trama que envolve a articulação entre explicação e compreensão na configuração da Mimese II, indicando o compromisso com a verdade histórica.

Mas como falar do conceito de verdade? Veyne (1984) nos ajuda nesse debate quando se refere a "programas de verdade". Ele afirma: "O que nos dará ocasião de constatar que o sentimento de verdade é muito amplo, mas também que verdade quer dizer muitas coisas [...] até englobar a literatura de ficção" (Veyne, 1984, p. 26). Em sua análise, destaca que há uma pluralidade de programas de verdade ao longo dos séculos, programas que estabelecem 
uma relação de força e de disputa, e o conhecimento "é o produto dessas forças, não o reflexo de seu objeto” (Veyne, 1984, p. 100).

Mas as verdades não estão inscritas como as estrelas sobre a abóbada celeste: são a pequena esfera de luz que aparece no extremo da luneta de um programa, de tal modo que a dois programas diferentes correspondem evidentemente duas verdades diferentes, mesmo que seu nome seja o mesmo (Veyne, 1984, p. 101).

Nesse sentido, a verdade se afirma como construção histórica, como resultado de um processo de luta e disputa situadas no tempo e no espaço. Qual programa de verdade constitui referência para professores/as que narram suas biografias educativas em contexto de pesquisa e formação? Essas narrativas consistem em uma "invenção de si"? Uma invenção no sentido ficcional ou aliada a um determinado programa de verdade? Em uma reflexão sobre a autobiografia no contexto literário, Lejeune (2003) levanta aspectos importantes e destaca duas posições conceituais frente à autobiografia. A primeira, tomando como fundamento a psicologia ("crítica da memória, ilusões da introspecção") e a narratologia ("toda narrativa é uma fabricação"), entende que essa produção não tem nenhum compromisso com a verdade e que, nesse sentido, confunde-se com a ficção. A segunda, que é defendida pelo autor, afirma que a autobiografia deve estar fundada na "estética da verdade" e numa "eficácia na transmissão de uma experiência vivida”. Dessa forma, confronta-se com a discussão do conceito de verdade e afirma:

Sem dúvida, a verdade é inatingível, em particular quando se trata da vida humana, mas o desejo de a alcançar define um campo de discurso e actos de conhecimento, certo tipo de relaçôes tanto no campo do conhecimento histórico (desejo de saber e de compreender) e no campo da acção (promessa de facultar esse conhecimento aos outros) como na área de criação artística (Lejeune, 2003, p. 41).

Como vimos anteriormente, a identidade é um processo de construção, de criação cotidiana, o que indica que tanto nos movimentos da vida quanto na escrita sobre ela o sujeito reconstrói imagens a respeito de si e de seu processo social. Tal fato não indica, segundo o autor, que ocorra uma "invenção 
de si mesmo" pelo narrador. Lejeune (2003, pp. 41, 46) sugere, assim, que a autobiografia esteja ancorada na tríade "belo, bem, verdadeiro", ou seja, na estética, na ética e na verdade. $\mathrm{O}$ autor também estabelece diferenças entre o leitor de ficção e o de autobiografia: o primeiro lê na busca do lúdico, do prazer; o segundo, na busca de compreensão dos caminhos da vida humana. Nesse sentido, o leitor de autobiografias é ativo, "reage antes de mais ao tipo de contacto que o autor estabelece” (Lejeune, 2003, pp. 41, 46). É como se o leitor fizesse parte de um tribunal do júri.

Cabe-lhe acabar o acto de conhecimento de uma vida esboçada no texto, perseguindo uma última palavra ou uma resposta que se espera dele. É o que já dizia Rousseau sobre o papel do seu leitor nas Confessions: 'Cabe-lhe reunir esses elementos e determinar que ser compõem eles; o resultado deve ser obra sua, e, se se enganar, então todo o erro será obra sua’ (Lejeune, 2003, p. 50).

Referindo-se, dessa maneira, ao leitor de autobiografias, Lejeune (2003) entende que ele vai à procura de compreensão das tramas da vida humana e, portanto, estas devem manter um compromisso com a verdade. Articulando as contribuiçôes dos autores citados às questôes anteriormente propostas com relação à especificidade das biografias educativas no contexto das ciências da educação, somos levados à uma perspectiva em que as narrativas de formação, bem como a análise que delas se pode fazer, trazem o compromisso, sim, com determinados "programas de verdade". Aqui, o plural é significativo porque fala de um programa tanto do ponto de vista do investigador como daquele/a que narra sua trajetória de vida. Entretanto, sendo o processo narrativo reflexivo e potencialmente transformador, a narrativa favorece uma reconstrução de si. Então, por um lado, concordamos com Lejeune, afirmando o compromisso com a verdade entendida como uma versão em disputa, mas, por outro, afirmamos que essa reconstrução é também um processo ficcional, já que a narrativa memorialística seleciona, articula e, nesse sentido, é inventiva. Entendemos, dessa forma, que a narrativa de formação, como invenção de si, mediatiza dialeticamente a ficção e a busca de afirmação de programas de verdade que, muitas vezes, se acham em disputa na interioridade do próprio narrador.

A defesa das possibilidades da verdade na narrativa levou Ricoeur (1994, 1996) à análise da polarização entre explicação e compreensão, bus- 
cando uma nova perspectiva de análise. A explicação caracteriza o modo de produção do conhecimento ligado às ciências naturais, assenta-se no detalhamento dos processos, tendo em vista uma "lei" que será sempre manifesta em situações idênticas. Nesse sentido, a explicação associa-se à causalidade e à previsão - um conjunto de causas gera determinado fenômeno. Logo, o conhecimento dessas causas torna o fenômeno previsível, enquanto a compreensão diz respeito à uma análise global com relação aos fenômenos. Em uma abordagem nomológica, essas duas dinâmicas ocorrem de forma isolada e independente. Observamos que, no campo histórico, por um lado, inicialmente, houve uma busca de salvar a história do ceticismo, por meio da objetividade, valorizando-se a explicação; por outro, a crítica a essa perspectiva acarretou uma supervalorização da compreensão em detrimento da explicação (Ricouer, 1994, pp. 173, 175).

Ricoeur, entretanto, procura um fio condutor que articule explicação à compreensão: "esse fio condutor, na minha opinião, é a intriga, como síntese do heterogêneo. A intriga, com efeito, 'compreende', numa totalidade inteligível, circunstâncias, fins, interaçôes, resultados não desejados” (1994, pp. 182 , 194, 204). Dessa forma, a narrativa, como tessitura da intriga, integra explicação e compreensão:

Porque uma simples narrativa já faz mais que relatar acontecimentos na sua ordem de aparecimento. Uma lista de fatos sem ligações entre si não é uma narrativa. É por isso também que escrever e explicar não se distinguem [...] O que se pode distinguir é a narrativa e as provas materiais que a justificam: uma narrativa não se reduz a um sumário de seu próprio aparato crítico, quer se entenda por isso seu aparato conceitual, quer seu aparato documental [...] Explicar por que alguma coisa aconteceu e descrever o que aconteceu coincidem. Uma narrativa que fracassa em explicar é menos que uma narrativa; uma narrativa que explica é uma narrativa pura e simples (1994, p. 212).

A narrativa, por sua natureza, é explicativa, apresenta acontecimentos em sua especificidade, mas também em uma articulação de sentidos, como uma "história a ser seguida" (Ricouer, 1994, p. 214). Segundo Ricoeur, as histórias comportam ações, experiências, personagens, situações que mudam, reações, acidentes. Nesse sentido, Pollak (1992) distingue três elementos constitutivos da memória e da narrativa - acontecimentos, pessoas e lugares: 
os acontecimentos que podem ser vividos pelo próprio sujeito ou por uma coletividade da qual faz parte; as pessoas ou personagens conhecidas direta ou indiretamente; e lugares que também trazem um forte apelo à memória e estão presentes como referenciais.

As narrativas como tessituras de intrigas reúnem, assim, "as finalidades, as causas materiais, os acasos: uma intriga é uma mistura muito humana e muito pouco 'científica' de causas materiais, de fins e de acasos" (Ricouer, 1994, p. 244). A presença do acaso nos leva à noção de acidente que se apresenta como uma interrupção na continuidade narrativa, a forma dramática de uma mudança de sorte.

$\mathrm{Na}$ articulação desses elementos, a narrativa se afirma como síntese do heterogêneo, os componentes se articulam e compõem uma história que pode ser seguida, em um movimento que leva à conclusão. "Seguir uma história, com efeito, é compreender as ações, os pensamentos e os sentimentos sucessivos enquanto apresentam uma direção particular [...]" (Ricouer, 1994, pp. $215,218,320$ ), somos levados, assim, pelo desenvolvimento da narrativa e conduzidos por questões e impulsos que levam à conclusão do processo como um todo. Dessa forma, "compreensão e explicação estão inextricavelmente misturadas no processo: idealmente, uma história deveria explicar-se por si mesma" (Ricouer, 1994). O encaminhamento da narrativa à sua conclusão não indica, entretanto, que possa ser deduzido ou predito, mas que a história é aceitável, ou seja, que há uma possibilidade de sentido.

É por isso que seu problema não é nem deduzir nem predizer, mas compreender melhor a complexidade dos encadeamentos, que, cruzando-se, convergiriam para a ocorrência de tal acontecimento. Nisso, o historiador difere do físico; não busca ampliar o campo das generalidades à custa da redução das contingências (Ricouer, 1994, p. 220).

As intrigas, com efeito, são em si mesmas ao mesmo tempo singulares e não singulares. Falam de acontecimentos que só ocorrem nessa intriga; mas há tipos de armação da intriga que universalizam o acontecimento (Ricouer, 1994, p. 295).

O historiador não trabalha buscando generalizações entendidas como predições, mas coloca luz sobre a particularidade das contingências, remeten- 
do essas contingências ao conjunto da narrativa. Encontramos, nessa análise, pistas sobre a generalização, pois em uma abordagem interpretativa ela não se apresenta como lei, mas está presente no sentido de uma compreensão globalizadora da intriga, tanto em sua particularidade como no diálogo entre diferentes narrativas. Nesse caso, tal compreensão se afirma como um "programa de verdade" válido para aquele grupo e que em outras situaçôes e contextos pode ser útil como vestígio de uma dentre outras possibilidades de interpretação. Explicar, assim, não significa apenas transformar fatos em leis, mas sim estabelecer coligaçôes, pois a inteligibilidade na narrativa coloca-se na composição complexa do todo, em uma articulação indissociável entre explicação e compreensão. Entendida como apreensão do mundo como totalidade, o objetivo da compreensão é inalcançável e, nesse sentido, nossa possibilidade se coloca, nomeadamente, pela articulação de fragmentos e versões.

Ginzburg (1989) faz uma recuperação histórica do paradigma indiciário que procura o conhecimento não diretamente acessível à experiência humana por meio de indícios, vestígios e sinais, exigindo uma observação muito atenta sobre minúcias do movimento do real. A tessitura da intriga articula, assim, fragmentos da memória numa composição narrativa que, num trabalho rigoroso, mediatiza explicação e compreensão. Na perspectiva da pesquisa-formação, investigadores e participantes se envolvem em uma dinâmica de interpretação dessa tessitura, por meio de um diálogo com ela própria e com outras narrativas na construção do saber e da formação.

\section{Um "círculo virtuoso"}

[...] hoje consigo perceber que aprendi a pesquisar seguindo um caminho metodológico bastante sistemático, que inclui levantamento do problema e de questôes, elaboração do projeto, estudo teórico-metodológico, revisão de literatura, trabalho de campo e análise. Quero afirmar que, por um lado, essa organização continua fazendo sentido para mim - é o que vai dando inteligibilidade ao próprio pesquisar -; por outro lado, quando olho o caminho percorrido pela pesquisa, penso que posso afirmar que esse roteiro é apenas didático, tem como objetivo nos ensinar a caminhar, mas, de fato, as etapas se atravessam e são atravessadas pelo inesperado, pela interrupção, por idas e vindas que se misturam na intensidade da construção do conhecimento, da formação, da minha própria formação. [...] 
Nesse sentido, é significativo como a experiência que vivi com cada professora me ensinou, me transformou, mexeu por dentro na tessitura de concepções teórico-metodológicas.

[...] Penso, então, que estou em um momento de ruptura e aprendizagem instituinte, apresento o capítulo não como uma análise teórica sumária e prévia, mas como inventário pessoal de ancoragens que me deram suporte ao longo da caminhada, em uma articulação polifônica entre a experiência vivida com as professoras e o refazer dessas concepções (19 jun. 2007).

Tomando emprestada a expressão de Ricoeur (1994, p. 117), ao percorrer tanto as reflexões conceituais como a abordagem metodológica, visualizamos a perspectiva de um "círculo virtuoso"; um círculo que se repete, que insiste em se reapresentar quando centramos a análise nas potencialidades da abordagem (auto)biográfica em formação de professores/as, mas que se repete não de forma "viciosa", mas inventiva, instituinte e crítica.

Quanto ao movimento do próprio texto, é importante afirmar que os conceitos e as questôes que se foram desdobrando não consistem em um constructo teórico prévio ao desenvolvimento da pesquisa, mas em uma formulação que se deu ao longo do processo, em mediação com as escolhas de caminhos, bem como com o desenvolvimento efetivo da pesquisa junto às professoras portuguesas e brasileiras. As palavras do livro da vida nos ajudam a compreender que a trajetória dessa elaboração não foi, então, linear, assim como não pretende ser seu sentido - o processo expressa a complexidade da própria pesquisa, da construção do conhecimento, da formação em um diálogo entre reflexôes conceituais, opções tomadas e caminhos construídos. 


\section{Capítulo 5 \\ Caminhos trilhados}

Este capítulo apresenta os caminhos trilhados, a história da investigação, incluindo planejamentos, desejos e, efetivamente, a dialética do vivido em cada uma de suas etapas. Ancoramo-nos na contribuição significativa dos escritos do livro da vida ao longo de todo o texto, no qual registramos os avanços e recuos na configuração metodológica de nosso estudo.

Inicialmente, contamos a história, apresentando o caminho biográfico-espistemológico da investigação, especialmente, pelo encontro com a metodologia das histórias de vida. A seguir, a reflexão sobre o lugar do livro da vida, lugar que foi, a pouco e pouco, assumindo centralidade - no processo de sua escrita, seus múltiplos sentidos foram sendo delineados, e no item a cozinha como metáfora refletimos sobre o movimento da pesquisa como permanente construção de caminhos. Finalmente, fazemos o relato dos desdobramentos metodológicos, apresentando cada uma das etapas percorridas.

\section{Caminho biográfico-epistemológico da investigação}

Contando uma história: "fragmentos autobiográficos"

O encontro com a metodologia desenvolvida, na presente investigação, tem uma história que precisa ser contada. Sua origem não se coloca no doutoramento, do ponto de vista de seu início formal, mas sim como processo que se desenvolve ao longo de muitos anos, anteriormente à chegada da pesquisadora em Portugal. Narrar esse percurso compõe um exercício de 
explicitar a natureza biográfica não só do objeto de investigação, mas, nesse momento, especialmente, da escolha do caminho metodológico.

A análise do sentido da origem encontra o seguinte registro no livro da vida:

Se é preciso buscar, por motivos de organização interna, o momento fundacional da presente pesquisa, coloco-me frente a uma primeira questão epistemológica: um tempo, uma origem que não se permite demarcar de forma nítida e precisa. Vasculhando o passado, não encontro o sentido da origem nos intensos trâmites burocráticos desenvolvidos no primeiro semestre de 2004, na chegada em Portugal, nem mesmo no primeiro dia de trabalho na Universidade de Évora. Se não localizo a 'origem' em um 'tempo' e um 'espaço' delimitados, encontro, então, no 'desejo', nos movimentos de elaboração dos primeiros projetos de estudo, visando o doutoramento. O encontro/ desencontro com temáticas foram trazendo o adensamento de questóes que envolvem a docência, a memória, a narração; as leituras preliminares, a revisão de literatura feita no Brasil, as aulas de francês com a querida professora Georgina [...], as diferentes tramas que me trouxeram a Portugal com o objetivo de perseguir um desejo. Desejo que se materializa no aprofundamento da trajetória de professora-pesquisadora, no instaurar de um tempo de mais tranquilidade e calma (set. 2004).

É assim, no "tempo do desejo", que o doutoramento se coloca, bem como o encontro com a metodologia, desejo de adentrar nos movimentos da docência, de compreender as tramas que possibilitam formas instituintes de formação. Formação que não se limita à dimensão acadêmica, mas que atravessa a vida. Foi assim que a investigação, que resultou na dissertação de mestrado, teve como foco metodológico a inserção no dia a dia de uma escola dos primeiros anos do ensino fundamental no Brasil, buscando as possibilidades de construção de um saber não institucionalizado e que traz a potência do fazer coletivo. Naquele contexto, a participação no desenvolvimento do Polo de Memória e Narração ${ }^{1}$ buscou encontrar, no resgate memorialístico

1 O Polo de Memória e Narração foi implantado e desenvolvido pelo grupo de pesquisa Políticas de Formação de Professores nas Novas Configurações Sociais, pesquisa financiada pelo CNPq e coordenada pela professora Célia Linhares, na Universidade Federal Fluminense (UFF), nos anos de 1994-1997. "A proposta do polo era constituir um espaço de encontro entre profes- 
e na troca de experiências, uma alternativa emancipatória para a construção de saberes docentes.

Naquele trabalho de pesquisa, as categorias "memória" e "narração" estão presentes de forma marcante, e nele encontro uma busca de recurso metodológico numa "perspectiva biográfica", contudo, não propriamente na "história de vida". Além de recursos à observação participante no cotidiano da escola, a metodologia caminhou por meio de entrevistas biográficas temáticas, as quais trazem fragmentos da vida das professoras em função da problemática proposta na investigação. A dinâmica do Polo de Memória e Narração tinha como pressuposto a partilha de experiências significativas entre as professoras e os investigadores em um olhar para o passado, potencializando o presente e o futuro. ${ }^{2}$

O acompanhamento de processos de formação contínua de professores/as ${ }^{3}$ resultou na produção do artigo "Fragmentos autobiográficos" (Bragança, 2001a). Percebemos, nesse texto, um lugar marcante no sentido de instaurar uma etapa profícua de estudos, a qual se define após a conclusão do mestrado, indicando, assim, a continuidade do processo de investigação com uma aproximação mais específica do aporte biográfico, tal como o próprio título sinaliza. $\mathrm{O}$ artigo apresenta dinâmicas e oficinas realizadas com professores/as, em uma metodologia com recurso memorialístico e, ao mesmo tempo, analisa o sentido biográfico da formação.

O texto abre caminho para o aprofundamento do estudo das histórias de vida e indica alguns conceitos importantes. Nele, encontro a arqueologia de uma paixão epistemológica pela "memória" como categoria teórica e pela perspectiva das "histórias de vida" como desdobramento metodológico potente:

sores e professoras, onde o conhecimento pedagógico fosse produzido a partir da narração das experiências cotidianas vividas e pela rememoração da trajetória profissional" (Bragança, 1998, p. 44).

2 O artigo "A produção do saber na escola: possibilidades emancipatórias da narração na formação permanente do educador" (Bragança, 1998) traz a síntese da referida pesquisa.

3 O referido trabalho foi realizado durante os anos de 1996 e 2000, por meio da coordenação do Projeto Habilidades de Estudo, desenvolvido pelo Departamento Nacional do Serviço Social do Comércio. O projeto atua com crianças dos primeiros ciclos do ensino fundamental, oferecendo uma série de atividades que incentivam a curiosidade científica, a pesquisa, a reflexão crítica e a construção/reconstrução do saber. 
A palavra memória por si só tem um peso forte sobre meu imaginário. Sou forçosamente transportada aos meus arquivos pessoais, pelos quais tenho muito zelo: cartas, fotografias, cadernos e livros escolares, pequenas lembranças que, em seu conjunto, contam um pouco de minha história, história partilhada em vários contextos sociais ao longo dos anos. Cada uma dessas recordaçôes me leva em um movimento de volta à origem, no sentido da busca de um fio perdido no tempo; fio que, no conjunto de outros fios, compóe uma teia, uma rede de interdependências onde vida pessoal, profissional, afetiva, religiosa se inter-relacionam (Bragança, 2001a, p. 109).

A importância atribuída aos arquivos pessoais foi tornando-se cada vez mais presente; de maneira intuitiva, algo falava da importância desses registros. O ingresso como professora universitária, ${ }^{4}$ a atuação específica no campo da formação de professores/as e a participação em projetos institucionais de investigação ${ }^{5}$ contribuíram para adensar os estudos nesse campo e buscar fundamentação em uma metodologia com aporte específico nas histórias de vida de professores/as. No desenvolvimento dos Núcleos de Memória, do Vozes da Educação, ${ }^{6}$ nas oficinas da UERJ sem Muros e no cotidiano das aulas de filosofia da educação e prática de ensino, o recurso à análise da trajetória das experiências da vida foi reforçando a importância desse caminho como possibilidade de formação.

Dessa forma, a continuidade dos trabalhos de investigação, realizados após a dissertação de mestrado, trouxe o adensamento teórico-metodológico e a aproximação das "histórias de vida". Contudo, em abordagens que, segundo a análise de Josso (2002a), são pertinentes a uma perspectiva de "projetos”, pois em nenhuma das experiências anteriormente referidas houve um trabalho centrado na globalidade temporal. O caminho percorrido foi, então,

4 Professora da Faculdade de Formação de Professores da Universidade do Estado do Rio de Janeiro (FFP/UERJ) e do curso de pedagogia da Universidade Estácio de Sá (UNESA), a partir de março de 2000.

5 Núcleo de Pesquisa e Extensão Vozes da Educação: Memória e História das Escolas de São Gonçalo e ALEPH - Programa de Pesquisa e Extensão da Faculdade de Educação da UFF, coordenado pela professora Célia Linhares

6 Uma das dimensões do trabalho dos Núcleos de Memória, implementados pelo Núcleo Vozes da Educação, é o trabalho com os fragmentos biográficos como possibilidade potencializadora da formação contínua de professores/as em suas interfaces com a memória da própria instituição escolar. 
a pouco e pouco, abrindo novas possibilidades e constituindo projetos de futuro que assumem contorno na presente investigação.

\section{O livro da vida}

Há uma semana, mais ou menos, iniciei a releitura do livro da vida com o objetivo de perceber os caminhos percorridos pela pesquisa, especialmente o registro do encontro com as professoras portuguesas e brasileiras nas entrevistas biográficas. O livro traz a tessitura da pesquisa, seu ir e vir e preciso retomá-lo para, por um lado, dizer sobre o desenvolvimento do trabalho; por outro, para compreender, de forma mais clara, o papel do próprio livro na pesquisa. Nesse reencontro, ao voltar aos primeiros escritos, não posso negar uma sensação estranha: é como se a Inês de hoje olhasse a Inês de três anos atrás e, nesse olhar, se percebesse diferente. Retomo também as primeiras dúvidas e questôes, os primeiros encaminhamentos dados à pesquisa e posso observar como foram sendo reconstruídos. Um importante espaço é dedicado à reflexão sobre os caminhos metodológicos, além de contemplar questionamentos sobre o trabalho, reflexões sobre leituras e suas relações com a pesquisa. Identifico dúvidas epistemológicas e teóricas que o desenvolvimento do trabalho conseguiu superar; minhas reações e aprendizagens frente às leituras. Percebo sua importância como espaço de reelaboração e construção dos caminhos da pesquisa. Me emociono, olhando as experiências, reconstruo alegrias e tristezas. É como se estivesse diante de uma tela e assistisse a um filme sobre os três últimos anos (27 jul. 2007).

O livro da vida coloca-se, assim, como narrativa escrita do processo de pesquisa, de questionamentos, de reflexões, de autoanálise do sentido da pesquisa em suas interfaces com a vida, em que tramas pessoais e acadêmicas se imbricam. E, logo cedo, vieram dúvidas sobre seu lugar na pesquisa: esse material constituiria um capítulo da tese ou, pelo contrário, deveria ficar restrito à investigadora e oculto na elaboração do trabalho?

[...] O livro da vida é o espaço da intimidade pessoal, é revelador da construção interna da pesquisa, é lugar do 'eu' pessoal se colocar nas crises vividas, na elaboração do pensamento a partir do diálogo com os outros. [...] Não seria, assim, parte integrante do trabalho? Seria menos científico por vir da experiência pessoal? ( 25 out. 2005) 
A continuidade de sua escrita foi, então, possibilitando resposta para essas indagações.

Já pensei no papel desse livro de diferentes formas, ou melhor, ele próprio foi se colocando e mostrando seu lugar ao longo do desenvolvimento do trabalho. Se, inicialmente, constituía um material à parte e de âmbito particular, aos poucos foi mostrando sua centralidade como registro privilegiado da pesquisa, na explicitação de seus fios condutores (20 fev. 2006).

Depois de algumas reflexões, e das orientações do professor Bravo Nico sobre a forma de preservar o sentido peculiar de seu texto e, ao mesmo tempo, afirmar sua presença, chegamos à dinâmica textual que pôde ser observada ao longo dos capítulos anteriores. O livro da vida não consiste em um texto à parte, pois sua presença perpassa cada etapa do trabalho, acompanhando sua elaboração. Assim, suas reflexões foram inseridas como lampejos ao longo do texto, e a leitura desses lampejos nos projeta para diferentes tempos e espaços de escrita, contextualiza e indica questões e impasses da construção do trabalho.

Neste capítulo, seu papel assume, entretanto, uma natureza diferenciada, pois o início do trabalho de campo, desenvolvido ao longo do ano de 2006, incorpora ao livro uma nova dimensão, já que passou a abrigar também o papel de caderno de campo - foi nesse mesmo texto que inserimos o relato dos primeiros contatos com as professoras e as trilhas, emoções e aprendizagens de cada encontro. Nesse sentido, trazemos muito de uma escrita tecida ao longo do processo da pesquisa, da forma como foi registrada no livro da vida, e vamos, como na feitura de uma colcha, costurando diferentes retalhos em uma composição que integra uma pluralidade de cores e imagens, aqui traduzidas em histórias, contextos, pessoas, lugares, acontecimentos; enfim, uma "tessitura de intrigas".

Mas agora é preciso dizer que o livro da vida transforma-se em diário de campo. É nesse mesmo espaço que registro as emoçōes e angústias da trajetória portuguesa desse trabalho acadêmico, em que também farei as anotações que vêm do campo, do contato com diferentes cidades, escolas e professoras. De fato, a natureza do texto é a mesma e no campo estou desde que, no dia 6 de setembro de 2004, cheguei a Portugal. A exploração, o conhecimento e a 
vivência em um espaço vital, geográfica e culturalmente diferenciado daquele onde passei todo meu percurso de vida, deram ao doutoramento um sentido de acontecimento biográfico e instituiu o trabalho de campo como movimento inerente. Foi preciso circular de autocarro, metrô e comboio, procurar as bibliotecas e centros de investigação, esquadrinhar a beleza do centro antigo de Lisboa, dos azulejos, dos museus, dos marcos históricos. Foi preciso adentrar as pequenas tramas burocráticas que possibilitaram nossa existência legal: cartão de utente do Centro de Saúde, cartão do contribuinte, IRS, matrícula escolar do Caio... Foi preciso conhecer a escola de $1^{\circ}$ ciclo em Portugal, seus professores, a dinâmica da formação inicial e contínua, participar de diversos congressos; enfim, estar em um intenso campo de trabalho, estudo e vida. Parece que, se o trabalho de campo já começou há tempo, hoje, toma ares de nova etapa. Muitas leituras e estudos foram tecidos, visando à preparação para este momento, para o desenvolvimento do trabalho biográfico junto às professoras de $1^{\circ}$ ciclo ( $1^{\circ}$ fev. 2006).

Considerando, então, a centralidade do livro da vida no presente capítulo, bem como sua peculiar forma de escrita, é importante fazer o questionamento sobre o ritmo de sua elaboração. $\mathrm{O}$ diário pressupõe a escrita contínua. Já o livro da vida foi utilizado como espaço de liberdade e, portanto, colocou-se fora do cronograma da pesquisa, ou seja, não constituiu um movimento obrigatório, mas, pelo contrário, espaço de liberdade e, portanto, de um ir e vir não marcado no calendário. Encontramos, dessa forma, registros de situações no mesmo dia de seu acontecimento, bem como escritos que fazem a síntese de meses de trabalho.

Depois de passado algum tempo, sinto sempre alguma emoção ao retomar o livro da vida, não consigo me aproximar dele quando estou muito atarefada, agitada, também não consigo escrever em momentos muito intensos de tristeza ou alegria. Ao contrário de todos os passos da pesquisa, não tenho data marcada no cronograma para escrever nesse livro, o seu lugar tem que ser preservado como espaço do desejo e de uma motivação interna muito forte. Observo que assume um papel importante no movimento de reflexão sobre a pesquisa e seus caminhos, ajuda a escrever as idas e voltas e delimitar os caminhos; é também o lugar do registro do trabalho de campo, das emoções, angústias e sofrimentos desse percurso (21 jul. 2006). 
Tomando então esse texto, com sua especificidade e natureza, como recurso privilegiado, passamos ao relato sobre o desenvolvimento da investigação.

\section{A cozinha como metáfora: o preparo da "sopa" e de seus ingredientes}

Para além das leituras, estudos, organização do trabalho de campo e tudo que o doutoramento implica, a vida aqui em Portugal trouxe muitas aprendizagens, algumas mesmo inesperadas. Uma delas vem a cada dia colocando-se de uma forma particular: a culinária. Lembro que na infância tive algum interesse pela cozinha, mas depois de alguns incidentes críticos fui afastando-me e envolvendo-me em outras tarefas e, logo cedo, os estudos e o trabalho me tomaram. Assim, a cozinha, sempre bem administrada por minha mãe, passou ao largo de minha formação pessoal. É claro que aquele cardápio chamado 'básico' eu sabia e foi este que coloquei em prática após o casamento, tendo sido 'minimamente' desenvolvido ao longo dos anos. Em nossa vida lusitana, entretanto, na divisão das tarefas domésticas, fiquei responsável por este e outros itens cotidianos. Inicialmente, tudo corria como o previsto, dei continuidade à aplicação daquele cardápio básico. Contudo, a cada dia fui me vendo envolvida de uma forma interessante com a cozinha. Depois de longas horas de trabalho acadêmico, começava a desejar 'ir para a cozinha' fazer algo de especial. Inicialmente, apenas seguindo as receitas do livro que minha mãe, carinhosamente, preparou para que trouxesse para Portugal. Agora, me vejo interessada em novas aprendizagens, nos sabores das comidas portuguesas, das hortaliças que não temos no Brasil, de doces, bolos... Tenho uma sensação de desafio cumprido quando faço algo que é aprovado por Junior e Caio e, às vezes, até por nossos convidados, mas uma sensação de desgosto quando tudo 'dá para o torto'. Céus! A primeira panqueca era disforme e o bolo de chocolate, no qual depositei todas as esperanças e desejos, virou uma 'musse'. Pensei: 'Nunca mais faço bolo! Quanto tempo perdido! Quanto envolvimento para no final.... Para no final a transferência de uma aprendizagem da vida para a cozinha: é preciso tentar outra vez! É preciso buscar outros caminhos, no caso do bolo descobri que a temperatura do forno é fundamental. Fiz essa 'grande' descoberta depois de algumas tentativas. Talvez esteja me deixando viver na cozinha novos prazeres, a aprendizagem de um fazer artesanal, de uma prática que articula dialeticamente princípios 
à ação ativa do sujeito que se deixa transformar, enquanto transforma misturas em sabores, sabores em momentos simples e intensos em família.

As complexidades, sempre presentes do processo de doutoramento, me tomam de forma intensa a vida. Vivo particularmente a ansiedade do limiar do início do trabalho de campo. Já tenho, a princípio, um planejamento detalhado do movimento, mas sinto um frio no estômago: será que terei professores/as interessados/as em participar do trabalho que estou propondo? Dispostos/as a dedicar tempo para a partilha de experiências, para a rememoração? Que tipo de relacionamento vou conseguir estabelecer com eles/ elas? Uma estrangeira na escola... Bom, mas penso que é nossa relação com a escola e com os professores que vai nos dar pistas e novos encaminhamentos para o trabalho.

Talvez precise entrar em contato com as professoras tal como entrei na cozinha: com abertura e disponibilidade para viver novas experiências, aprendizagens. Sabores que não estão definidos previamente, mas que precisam ser buscados, experimentados, na alquimia das relações e da partilha. E, se algo 'der para o torto', esse algo não é estranho, mas faz mesmo parte do movimento de pesquisa, assim como da vida, da natureza do aprender. É sempre possível tentar novas panquecas e bolos, inclusive seguindo, para isso, novos caminhos (27 out. 2005).

O tempo vai passando e o ritmo parece-me a cada dia mais cronológico e menos kairótico. Por natureza, gosto dos cronogramas, da organização minuciosa do tempo e do espaço, metas, objetivos a cumprir, prazos - fazem parte de uma organização pessoal que toma espaço em diferentes dimensões da minha vida, passando pela rotina diária dos cuidados com Caio aos afazeres domésticos, marcando os movimentos da vida e da pesquisa. Por outro lado, estou sempre desejando apreender e deixar-me tocar pelo ritmo kairótico, o tempo da oportunidade, o tempo propício da ação é o tempo que conjuga possibilidade e desejo, é um tempo que consegue se impor rompendo toda expectativa de um cronograma organizado. É nesse tempo kairótico que muitas experiências instituintes se fundam, o tempo de uma construção não previsível e imponderável (1º nov. 2005).

Preciso desenvolver o trabalho de campo em Portugal e tenho nove meses, talvez seja o tempo mesmo necessário de uma gestação, necessário 
para trazer à luz, na perspectiva da maiêutica socrática, um conjunto de indícios fundados em uma relação mais direta com a docência e a formação de professores do $1^{\circ}$ ciclo do ensino básico. Diante dessas reflexões, busco articular as potencialidades da dimensão cronológica e kairótica da pesquisa. Preciso aprender e incorporar o imprevisível, desenvolver uma 'escuta sensível' ao movimento inerente de cada etapa, entendendo que a construção do caminho confunde-se com o próprio caminhar, com a própria pesquisa. Por outro lado, é preciso abrir o leque de possibilidades que, garantindo os objetivos da pesquisa, possa desdobrar-se de diferentes formas. As reflexões que me tomam indicam provisoriamente alguns caminhos... (1ำ nov. 2005).

Ao falar assim dos "caminhos trilhados", encontramo-nos com um movimento que não estava previamente dado, mas foi sendo construído ao caminhar. E, assim, fomos buscando, ao longo da pesquisa, sensibilidade para com o processo que foi se desdobrando, com o desenvolvimento concreto da pesquisa e do caminhar; eram várias as possibilidades que foram sendo materializadas, efetivamente, ao longo da pesquisa. No próximo item, passaremos à narrativa das trilhas construídas ao longo do processo.

\section{Abordagem metodológica}

\section{Os contornos}

O caminho trilhado pela investigação-formação consistiu na realização de três entrevistas biográficas com cada uma das 13 professoras participantes - sete professoras em Portugal, que vivem e trabalham na grande Lisboa, no Porto e em Évora, e seis no Brasil, de São Gonçalo, do Rio de Janeiro e de Bom Jesus do Itabapoana.

Com a primeira professora portuguesa, desenvolvemos um "ensaio", ou seja, os encontros que tivemos seguiram todo o caminho proposto para a metodologia. Entretanto, a análise de sua trajetória não foi incluída neste estudo, considerando que essa etapa teve como objetivo possibilitar um momento de reflexão sobre os movimentos da pesquisa. Seguiu-se, então, a investigação com as seis professoras do $1^{\circ}$ ciclo do ensino básico, em Portugal $\mathrm{e}$, posteriormente, com as seis professoras brasileiras que atuam nos primeiros 
anos do ensino fundamental. Ressaltamos que as professoras se encontram em diferentes momentos da carreira profissional. ${ }^{7}$

Para a condução das entrevistas, utilizamos um roteiro orientador, previamente analisado por professores especialistas. ${ }^{8}$ Após a montagem do referido material e da realização das entrevistas com a primeira professora participante, pudemos definir com mais clareza a dinâmica da investigação-formação. Em uma etapa de preparação, tanto em Portugal como no Brasil, tomamos como objetivo fazer os primeiros contatos, montando, assim, um calendário de entrevistas com as professoras. Na confirmação do primeiro encontro, solicitamos que levassem um objeto significativo de sua trajetória de vida-formação para a primeira entrevista. Como referido anteriormente, o desenvolvimento se deu por meio de três entrevistas biográficas, sendo as duas primeiras para a narrativa e a terceira para a análise partilhada da narrativa.

No primeiro encontro, lemos e discutimos os objetivos da investigação e uma síntese da metodologia e das etapas do trabalho, por meio de um quadro impresso entregue às professoras, visando dar referências sobre o sentido das entrevistas. Posteriormente, fizemos a leitura e a discussão do "contrato de trabalho", material formulado previamente que continha os princípios deontológicos tomados como base da investigação, os quais traziam implicações à participação do/a entrevistado/a. ${ }^{9}$ Em consideração tanto à proposta metodológica quanto aos princípios do contrato, todas as professoras se manifestaram positivamente, aceitando participar da investigação.

Depois da discussão formal dos caminhos da investigação, passamos a um momento de reflexão, por meio da leitura e da discussão do livro Guilherme Augusto Araújo Fernandes, de Men Fox, o qual traz, com a linguagem do mundo infantil, as complexidades da memória e da formação. Por um lado, a história da amizade de um menino e de uma senhora muito idosa indica as sendas de uma formação que atravessa as diferentes etapas da vida e que se constrói em partilha; por outro, a construção, por Guilherme Augusto, de uma "cesta" com uma diversidade de objetos para que a D. Maria Antô-

\footnotetext{
7 De fato, tal como analisado pela professora doutora Idália Sá-Chaves, no almoço de confraternização após o júri de defesa da tese, realizado no dia 15 de junho de 2009, a investigação contou com 14, e não 13 participantes, visto que a investigadora também atuou como sujeito no processo de investigação-formação.

8 Cf. anexo 1.

9 Cf. anexo 2.
} 
nia pudesse retomar suas lembranças foi o gancho para que cada professora fosse convidada a narrar a história do objeto significativo que levou para esse primeiro encontro, objeto que fizesse referência a um acontecimento de sua trajetória de vida-formação.

Qual o sentido da leitura de um livro de literatura infantil em uma entrevista biográfica? Por que partir de um objeto para deflagrar o processo narrativo pelas professoras? Além de possibilitar uma reflexão sobre os sentidos da memória e da formação, a presença do livro procurou colocar-nos, professoras e investigadora, no contexto de um processo que se desejava formador e partilhado, rompendo com a postura clássica das entrevistas. Pudemos sentir, no olhar das professoras, nesse momento em que ainda não nos conhecíamos tão bem, certo ar de "surpresa" que foi, a pouco e pouco, instaurando um espaço-tempo de maior liberdade. Já o objeto veio para romper com a linearidade do próprio roteiro - organizado de maneira que tocasse as diferentes fases da vida em uma sequência. Assim, iniciar o diálogo pela narrativa de um acontecimento biográfico, materializado em um "documento pessoal" escolhido pela professora, foi o caminho para romper com a cronologia e demarcar a possibilidade de que cada narrativa seguisse seu próprio curso. A partir daí, demos continuidade, no primeiro encontro, aos itens do roteiro relativos a memórias da infância, juventude e vida adulta e à trajetória como aluna. De acordo com o roteiro, o segundo encontro foi dedicado às experiências de formação inicial e contínua e à trajetória profissional.

A expressão "de acordo com o roteiro" assume aqui especial relevância, pois podemos afirmar que o que trazemos como "contorno metodológico" se refere, ainda, ao relato que foi planejado. Entretanto, a interação e a dinâmica estabelecida com cada professora foram peculiares, transformando e recriando esse roteiro prévio num movimento sempre novo; assim como tivemos oportunidade de seguir metodicamente os itens propostos, pudemos também vê-lo totalmente subvertido e recriado, em um processo narrativo cheio de idas e voltas. A presença do "objeto significativo" também foi muito variada, passando: pelo esquecimento; por sua presença "simbólica"; ${ }^{10}$ por sua apresentação no segundo encontro, e não no primeiro; e por sua utilização logo no primeiro encontro, como deflagrador de toda a narrativa tecida,

${ }^{10}$ Professoras que não levaram o documento de memória falaram sobre qual gostariam de levar e contaram a história referente a ele. 
até a presença de uma verdadeira "cesta de memórias", da qual a professora ia tirando os mais diversificados objetos, representativos de diferentes acontecimentos e fases da vida.

No final do primeiro encontro, entregamos um documento com os itens temáticos centrais do roteiro. ${ }^{11} \mathrm{O}$ cerne da investigação coloca-se, justamente, no processo mobilizador de uma narrativa reflexiva, potencialmente formadora; nesse sentido, o objetivo foi favorecer uma reflexão prévia ao momento da entrevista por parte das professoras.

Nos dois primeiros encontros, fomos conduzidos pela beleza de narrativas que, tomando a vida como espaço-tempo de formação docente, foram entrelaçando experiências vindas das memórias polifônicas dela, da trajetória acadêmica e profissional. Nesses relatos, encontramos muitos indícios de experiências instituintes de formação que ressaltam valores aprendidos junto aos pais, aprendizagens da vida nas aldeias, vilas e cidades, memórias como alunas da escola primária e da formação acadêmica, partilhas nutridas com alunos e colegas ao longo da trajetória profissional e tantas outras. Considerando o planejamento prévio de três encontros com cada professora, tivemos flexibilidade, não nos deixamos prender pelo roteiro, mas, pelo contrário, procuramos apreender a dinâmica própria de cada narrativa. As questóes e temáticas previstas para determinada entrevista puderam ser retomadas ao longo dos encontros pela própria professora ou, quando necessário, por meio de questôes formuladas pela investigadora.

O terceiro encontro assumiu grande relevância no caminho metodológico, pois foi destinado à interpretação partilhada da biografia educativa. Após a leitura das transcrições, cada professora foi convidada a discutir, em partilha, os sentidos do processo de formação. Nesse momento, foram apresentadas análises preliminares e indicativos encontrados pela investigadora e pela professora, conduzidos por um roteiro de reflexão. ${ }^{12}$ Incluímos também, no término desse último encontro, um momento de avaliação da investigação-formação. As professoras foram convidadas a elaborar, posteriormente, um texto escrito sobre os referidos aspectos, com avaliação relativa à participação no processo, refletindo sobre seus possíveis impactos no processo de formação. ${ }^{13}$ Observamos que esse encontro intensificou o sentido de forma-

\footnotetext{
${ }^{11}$ Cf. anexo 3.

${ }^{12} \mathrm{Cf}$. anexo 4.

${ }^{13} \mathrm{Cf}$. anexo 5.
} 
ção que se dá tanto para quem reflete sobre seus próprios caminhos na vida e na docência como para quem aprende ao ouvir a narrativa do outro e ao buscar nela fios de sentido.

Mas a pesquisa continuou nos instigando. Os caminhos se movimentam e se nutrem por meio de um intenso diálogo entre Brasil e Portugal, diálogo posto pela própria temática que nos reporta à contribuição e influência de autores portugueses na trajetória de pesquisa que temos desenvolvido no Brasil, nessa área. Assim, um primeiro sentido do diálogo materializa-se pelo intercâmbio entre a produção acadêmica desses dois países.

O doutoramento realizado na Universidade de Évora, o mergulho de um ano e dez meses na vida portuguesa, aponta um segundo sentido: é uma professora brasileira que observa e procura não só os caminhos da produção acadêmica no campo das histórias de vida, mas também os movimentos da própria escola, dos/as professores/as e da formação. Assim, as imagens, os sons, as experiências e, especialmente, a escuta e a análise das narrativas trazem a perspectiva de determinado filtro. Trata-se de um filtro estrangeiro e, como tal, o olhar para a vida e a profissão das professoras portuguesas é o olhar de um legítimo outro. Por um lado, é o olhar de uma brasileira para os movimentos e caminhos da vida e da profissão docente em Portugal; nesse sentido, são as experiências como professora e pesquisadora no Brasil que indicam as possibilidades de leitura e análise dessa realidade.

A narrativa das professoras brasileiras, por sua vez, permite escavar um contexto conhecido e vivido pela pesquisadora, mas que no estranhamento surpreende, levanta questionamentos e vai dando pistas de problemáticas que unem sentidos da formação docente e lampejos da especificidade de cada história. Além do diálogo entre a literatura e as narrativas de professoras portuguesas e brasileiras, este estudo talvez possa ser percebido, pelos leitores portugueses, como o olhar de uma estrangeira sobre sua realidade e, pelos brasileiros, como um convite à reflexão que insiste em se colocar toda vez que nos confrontamos com as semelhanças e singularidades que nutrimos em relação ao outro.

\section{Desenvolvimento da investigação}

Retomo a tessitura de um caminho de pedras portuguesas, pedras de diferentes cores, um caminho, um mosaico. A reunião com o professor Bravo Nico, ontem, foi definidora. As intuições e movimentos do percurso confirmam a 
decisão de trabalhar com entrevistas [...] Caminho traçado. Alívio! É preciso saber construir caminhos, é preciso elaborar internamente os indícios, as intuições (28 dez. 2005).

\section{A construção do roteiro e a contribuição dos professores especialistas}

Tomada a decisão de trabalhar com entrevistas biográficas, passamos à organização do trabalho de campo, que assumiu centralidade ao longo do ano de 2006, tendo seu desenvolvimento percorrido os meses de fevereiro a maio com as professoras portuguesas e agosto a dezembro com as brasileiras. A partir das orientações recebidas e da literatura estudada, elaboramos o roteiro das entrevistas biográficas, submetido à análise do professor orientador e, com sua resposta positiva, dos demais especialistas portugueses e brasileiros.

A possibilidade de diálogo com outros/as professores/as sobre o roteiro foi significativa para o desenvolvimento da pesquisa, diálogo que encaminhou um conjunto de reflexôes e de possibilidades de revisão e ajuste. Participaram duas professoras doutoras brasileiras, Célia Linhares e Cármen Pérez, e três professores doutores portugueses, Bravo Nico, António Nóvoa e António Neto. As análises e sugestôes dos professores foram, assim, incorporadas na revisão do roteiro.

As respostas das professoras brasileiras confirmaram a pertinência da estruturação desse roteiro, destacando a importância da relação do trabalho com as múltiplas linguagens que vêm da literatura, das imagens fotográficas, dos filmes, das músicas, uma dimensão que está presente, mas que poderia ser enriquecida.

Nas mensagens dos professores Bravo Nico e António Nóvoa, encontramos fios que revelaram um sentido comum: a preocupação com a possibilidade de que o encaminhamento das questôes se centrasse mais, efetivamente, nos aspectos da "vida docente". Assim, o roteiro foi retomado incorporando a formulação de questões mais explícitas para cada um dos eixos, buscando deixar claro que o olhar às dimensões pessoais da vida se colocava no sentido de perceber as experiências formadoras que traziam impacto sobre a docência.

O encontro pessoal com o professor doutor António Neto trouxe grande contribuição. Nossa conversa nos fez poder discutir aspectos relativos à natureza da investigação, à sua organização metodológica e às perspectivas de análise propostas. Termino com as palavras do livro da vida, fazendo re- 


\section{ferência ao sentido da participação dos mencionados professores nessa etapa da pesquisa:}

Fiquei encantada com a disponibilidade do professor Neto, que, durante duas horas, destacou, ponto por ponto, os aspectos que lhe chamaram a atenção na estruturação do roteiro. Foi um momento importante desse meu processo de formação, pela afirmação do doutoramento como espaço-tempo de partilha acadêmica entre professores, que podem 'ler', 'dizer' e 'orientar' aquela que como aluna-professora-investigadora procura construir um caminho partilhado do estudo não só com diferentes papéis e olhares, mas também com os indicativos pertinentes de revisão a serem feitos e incorporados (20 fev. 2006).

\section{A definição do número de participantes da investigação-formação e com- posição do grupo}

Ontem, em Évora, tive uma experiência de saudável confronto de ideias, de posiçōes epistemológicas, um diálogo fértil e desejável na construção da investigação. Conheci um professor e conversei com ele sobre a pesquisa, o foco principal, a metodologia, e o professor, com toda gentileza, confrontou-me com um conjunto de questôes. Se, por um lado, valorizou a temática proposta, por outro, questionou a validade da metodologia, sua representatividade. É possível chegar-se a conclusões válidas a partir de narrativas de um número reduzido de sujeitos? Não será necessário fazer o levantamento com um grande número, para, a partir daí, mesmo em uma perspectiva qualitativa, inferir algumas conclusōes? No diálogo, insisti sobre a natureza qualitativa da pesquisa e na não generalização, ou seja, cada narrativa vale por ela própria, e não por encontrarmos princípios aplicáveis a uma totalidade. Referi-me ainda ao debate entre Bertaux e Ferrarotti, o primeiro defendendo a perspectiva da saturação, ou seja, entrevistar o maior número de pessoas possível até chegar-se a repetição de informações e, assim, o investigador pode saber que já tem o material empírico necessário. Já Ferrarotti insiste na subjetividade explosiva como grande contribuição das narrativas, ou seja, nas histórias de vida, temos, por meio da mediação, o encontro com a realidade social mais ampla. Muito mais do que o questionamento do número de participantes, vi um confronto de natureza epistemológica. [...] A definição do número de participantes em um estudo biográfico, desde o estudo de caso único até os estudos múltiplos 
com a participação de muitos envolvidos, reafirma a não possibilidade de, no trabalho de investigação, encontrar dada realidade ou uma verdade fechada sobre qualquer que seja a questão, mas, voltando ao paradigma indiciário de Ginzburg, encontrar apenas indícios, pistas, sinais, válidos para aquele contexto trabalhado, os quais contribuem no sentido de 'iluminar', de alguma forma, caminhos futuros em outros contextos (28 dez. 2005).

Quantos professores/as fariam parte do trabalho? E quais os critérios para o convite tendo em vista a participação na pesquisa? Essas foram questôes amadurecidas ao longo de algum tempo. Chegamos ao número de seis professoras portuguesas e seis brasileiras, ${ }^{14}$ um universo bastante ampliado, se tomarmos em consideração a natureza e os desdobramentos metodológicos de um estudo biográfico. Contudo, a proposta era que, a partir desse universo, tivéssemos a possibilidade de, posteriormente, escolher narrativas que de fato fizessem parte do estudo. Entretanto, quando concluímos as entrevistas com as professoras portuguesas, chegamos à conclusão de que cada uma delas passou a fazer parte da pesquisa de tal forma que não tínhamos como fazer a seleção de algumas narrativas, não era possível pensar o desenvolvimento do trabalho sem a presença de cada uma das professoras que já haviam narrado suas trajetórias de vida. E, considerando o caráter dialógico do estudo, era importante garantir o mesmo número de professoras brasileiras participantes, motivo pelo qual se configurou o referencial de 12 professoras.

E como foi feita a escolha dos/as participantes? O primeiro critério foi a diversidade de experiências e caminhos trilhados no magistério do $1^{\circ}$ o ciclo do ensino básico em Portugal e nos primeiros anos do ensino fundamental no Brasil, bem como a diversidade de experiências do ponto de vista dos contextos históricos, culturais e geográficos. Assim, as professoras convidadas encontravam-se, no instante da realização da pesquisa, em diferentes momentos da trajetória pessoal e profissional, incluindo o início da carreira, tempo médio e final de carreira, professoras em exercício e professoras aposentadas. A diversidade se manifesta ainda na constituição de um grupo que fala da docência em dois países e em três diferentes cidades em cada um deles, incluindo uma com características rurais no Brasil e outra em Portu-

${ }^{14}$ Além da primeira professora participante, que contribuiu configurando uma aproximação da metodologia proposta. 
gal. A intencionalidade incidiu justamente na composição de um grupo que pudesse trazer múltiplas e polifônicas experiências de vida e de formação, e nessa multiplicidade buscamos não a generalização ou a possibilidade de previsibilidade no conhecimento científico, mas o diálogo que pudesse abrir caminhos analíticos de compreensão dos movimentos constituintes e instituintes da formação docente.

Outro critério importante foi o envolvimento com a docência, ou seja, professoras que, apesar de lutas e contradiçóes, têm na docência um dos lugares importantes na atribuição de sentido e significado para a vida. Portanto, não foram consideradas previamente as concepções e práticas pedagógicas desenvolvidas, mas sim o compromisso e o envolvimento com a docência. É importante destacar que não houve critério relativo à atuação com um grupo apenas feminino, fato que se deu a partir dos contatos estabelecidos e das indicações recebidas no desenrolar da pesquisa. Entretanto, a composição do grupo revela efetivamente a face feminina da docência no nível de ensino focalizado.

Como ocorreu o encontro da pesquisadora com as participantes? Em Portugal, os contatos se deram por aproximação com as duas escolas nas quais foi realizado o estudo exploratório e também por indicação do professor orientador. Assim, conhecíamos previamente três das sete professoras; com as outras quatro, o contato inicial foi apenas telefônico. No Brasil, apesar de toda natural inserção e proximidade, o fato de desenvolvermos o estudo em cidades diferentes e de buscarmos professoras também em diferentes fases da carreira levou-nos a entrar em contato com apenas duas professoras com as quais já tínhamos um relacionamento anterior, as da cidade de São Gonçalo, as quatro demais foram indicadas por amigos professores que têm conhecimento mais próximo dos municípios do Rio de Janeiro e de Bom Jesus do Itabapoana.

\section{O contrato de trabalho: critérios deontológicos}

Como anteriormente discutido na revisão de literatura, o "contrato de trabalho" assume uma relevância fundamental na pesquisa (auto)biográfica. Tomamos como fonte de conhecimento a vida e a história de pessoas que têm o lugar de sujeitos participantes da investigação. No caso da presente investigação-formação, tanto as professoras convidadas como a investigadora 
colocam-se em um movimento de aprendizagem e formação, o que indica a necessidade de socialização e aceitação, pelas mesmas, da natureza da investigação, em seus princípios e metodologia, bem como das implicações de sua participação.

Dessa forma, no primeiro encontro, dedicamos um momento à leitura e discussão de documentos que apresentam a pesquisa e do "contrato de trabalho". A elaboração desse último se deu a partir da contribuição da leitura dos diversos trabalhos indicados na revisão de literatura e, especialmente, do documento formulado pela L'Association Internationale des Histoires de Vie en Formation (ASIHVIF). Com base nessas referências, nós o revisamos e adaptamos, em função das especificidades de nossa pesquisa.

Dentre os vários aspectos abordados, destacamos: a implicação voluntária; a confidencialidade dos nomes dos/as entrevistados/as e dos respectivos locais de trabalho; e a autorização para a utilização do material, bem como para sua publicação. Quanto ao primeiro aspecto, a implicação das professoras na investigação se realizou por meio de convite, telefonema ou e-mail. Nessa primeira aproximação, procuramos apresentar em linhas gerais a natureza da investigação e a metodologia das entrevistas, especialmente o fato de serem gravadas, já que esse recurso seria fundamental para o desenvolvimento do trabalho. Tivemos a preocupação de favorecer a implicação voluntária, ou seja, de que o convite realmente fosse bastante aberto e deixasse as professoras suficientemente à vontade, caso não fosse possível participarem ou não tivessem interesse. Porém, em todos os casos, fomos recebidas com muita gentileza e amabilidade por parte das professoras.

Lembro da forma como aprendi a fazer, aqui em Portugal, um bolo de chocolate: foram necessárias algumas tentativas, alterar a receita, perceber aos poucos o tempo de cozimento. O tempo, o tempo, o tempo, idas e voltas. É preciso planejar, investir ação, mas sobretudo viver a experiência no seu tempo, saber esperar. E, ainda, acolher os movimentos que vêm da própria pesquisa, movimentos que não se deixam disciplinar, nem 'calendarizar', mas que vão dando certa vida própria à pesquisa, ao processo de construção do conhecimento (4 mar. 2006).

Dando o necessário tempo, tal como na "aprendizagem de fazer o bolo", fomos buscando desde os primeiros contatos conjugar três elemen- 
tos: o planejamento prévio cuidadoso, a importância de encontrar o ponto de equilíbrio em nossas falas e relações e a necessária reflexividade crítica ao longo do processo. Depois da aceitação inicial de cada professora, podemos afirmar que foi mesmo o desenvolvimento do trabalho que favoreceu o estabelecimento de laços e relaçôes com a pesquisa; cada uma, a seu tempo e com diferentes intensidades, foi-se envolvendo, compreendendo o sentido da pesquisa e interagindo com mais liberdade e confiança.

Outro aspecto significativo do "contrato" foi a confidencialidade dos nomes. Inicialmente, tivemos muitas dúvidas sobre como proceder e nos posicionar frente a essa questão, pois, se, por um lado, o anonimato favorece espaço para uma narrativa que permita relatar situações difíceis, dolorosas e até mesmo indesejáveis, por outro, oculta a identidade do sujeito que é o autor de sua narrativa. Foram os estudos da revisão de literatura que, mais uma vez, ajudaram a desembaraçar os caminhos. Quanto ao anonimato, Sarmento (2002) argumenta que, embora o sujeito participante queira revelar sua identidade, ou não veja inconveniente nisso, em uma narrativa de vida, outras pessoas são necessariamente citadas, e estas não participam da "contratualização" do trabalho, o que causa um problema de natureza ética. Com base nessas reflexóes, incorporamos como um dos princípios do contrato a "confidencialidade" dos nomes.

No Brasil, entretanto, tivemos, com duas das professoras participantes, a manifestação do desejo de que seus nomes fossem mantidos:

Perguntei se havia pensado sobre o nome a ser atribuído durante a pesquisa, ela disse que não e que queria mesmo me perguntar se seria necessário. Foi a primeira professora a me fazer essa pergunta, e pudemos trocar ideias. Inicialmente, minha resposta foi que essa é uma proposição que segue os princípios deontológicos definidos anteriormente, mas que eu entendia que, se ela tivesse outra posição, ou seja, se se sentisse confortável e desejosa de revelar sua identidade, poderia ser uma opção pessoal. Relatei para ela, então, o percurso de minha reflexão sobre o assunto, destacando que, inicialmente, também tive dúvidas a esse respeito, mas que a literatura e especialmente outros trabalhos dessa natureza, em Portugal, apontavam na direção do anonimato (10 ago. 2006). 
Desse modo, a partir da solicitação de duas professoras brasileiras, seus nomes foram mantidos. Quanto à autorização para o uso do material, bem como para sua publicação, tivemos, nesse momento inicial, a aceitação oral de todas as professoras. Não fizemos um documento escrito, guardamos apenas a gravação das entrevistas, portanto, o depoimento oral das mesmas, porque consideramos que esse procedimento traria excessiva formalização ao processo. Posteriormente, encaminhamos pelo correio as biografias educativas para leitura pelas professoras e anexamos a carta de cessão, ${ }^{15}$ que foi assinada e reenviada para a investigadora.

Quanto ao "contrato”, podemos concordar com a reflexão de Ferrarotti (1990). De fato, na presente pesquisa, ele foi produzido em duas dimensóes: uma formal e outra informal. Do ponto de vista formal, o "contrato de trabalho" se deu por sua leitura, discussão e aceitação pelas professoras participantes, mas na dimensão informal podemos afirmar que se foi desenvolvendo na relação de confiança conquistada ao longo do processo.

\section{O registro do não verbal e a transcrição das entrevistas}

Após as entrevistas, surgiu o desafio dos registros escritos. Nesse momento, o livro da vida constituiu espaço para o relato informal das impressões sobre cada entrevista, incluindo a dinâmica de interação entre as participantes, ou seja, as professoras e a investigadora, e para destacar a intensidade do não verbal (Poirier et al., 1999, p. 59). Nesse sentido, a cada entrevista seguiu-se a narrativa escrita no livro da vida, visando captar ao máximo a intensidade da experiência vivida e, posteriormente, a transcrição.

O mês de fevereiro está sendo, de fato, intenso, com a sistematização do roteiro, por meio da contribuição dos especialistas e a realização das primeiras entrevistas. Preciso registrar que fiquei assustada com o tempo necessário para as transcrições. Minha experiência na realização de entrevista ainda é pequena e referida, especialmente, à pesquisa no âmbito do mestrado, quando recebi ajuda da minha querida amiga Luiza na transcrição. E agora, no doutoramento, com as primeiras entrevistas, percebi a extensão desse trabalho e o tempo necessário para sua realização. As entrevistas biográficas ainda mais, pois são,

${ }^{15}$ Cf. anexo 8. 
por natureza, mais extensas, e está sendo também outro aprendizado. Na primeira, fui tateando; na segunda, já fui sistematizando alguns procedimentos 'técnicos' que contribuem para maior agilidade e eficiência (20 fev. 2006).

O desenvolvimento da pesquisa foi mostrando a importância da transcrição como uma das etapas do trabalho com entrevistas biográficas. Essa etapa, inicialmente, trouxe grande dificuldade, em virtude do tempo necessário para sua realização e por desafiar o desenvolvimento de uma habilidade predominantemente técnica. Entretanto, é importante registrar que aos poucos a transcrição das entrevistas foi mostrando que, além de sua dimensão técnica, é um processo de grande importância nessa abordagem de pesquisa. O discurso oral precisa ser materializado em texto escrito para ser analisado detidamente pela pesquisadora. Quais são os desafios desse processo? Qual é caminho a ser percorrido pela narrativa das professoras, passando por sua elaboração oral, a transcrição, como proposta de registro fiel da narrativa e sua posterior elaboração em biografia educativa? Nesse momento, essa era apenas a primeira etapa do trabalho, ou seja, a transformação do texto oral em "cópia" escrita, e não foi sem sentido a recorrente estranheza das professoras quando leram as transcrições, pois a lógica que constitui a narrativa oral é diferenciada da narrativa escrita, e a transcrição como tentativa de "cópia do oral" acaba constituindo certa caricatura, pois lhe faltam os gestos, os olhares, o contexto e o outro a quem se dirige aquela narrativa. Mas atua como caminho importante na dialética entre compreender e explicar a tessitura da intriga que envolve a trajetória de cada professora participante.

É também significativo registrar que a transcrição efetuada pela investigadora foi sendo realizada metodicamente ao longo do processo, ou seja, a cada entrevista seguiram-se seu registro informal no livro da vida e sua transcrição, possibilitando um processo importante de apropriação das narrativas, pois cada entrevista foi ouvida repetidas vezes. Essa dinâmica contribuiu também para a análise de conteúdo, pois quando chegávamos a essa etapa cada narrativa já constituía um "filme", indicando uma compreensão ampla e contextual da história de vida contada, ao mesmo tempo que alguns indícios e sinais - como recorrências na linguagem, acontecimentos biográficos, interfaces entre diferentes dimensões formadoras, o lugar de pessoas e contextos - saltavam de cada uma das histórias narradas, ou seja, o movimento 
dialético entre compreensão e explicação já estava fortemente presente na própria voz da professora que havia sido repetidamente ouvida.

Logo, a transcrição passou a assumir um lugar importante no desenvolvimento da pesquisa, como revela a reflexão citada a seguir, de quando estávamos desenvolvendo a investigação-formação com a oitava professora, já no Brasil:

Retomo agora o desafio da transcrição. Pensei em ter a ajuda de alguém nesse trabalho, assim, poderia adiantar outras etapas da pesquisa, mas sou tomada pelo desejo de logo retomar a gravação da entrevista, de trazer de novo a fala da professora. Cresce o sentimento de que a transcrição faz também parte do trabalho, pois coloca-me de forma intensa em contato recorrente com a narrativa, produz um movimento importante de apropriação e significação fundamentais à continuidade do próximo encontro (3 ago. 2006).

É importante registrar também as aprendizagens que surgiram do ponto de vista técnico. ${ }^{16}$ Consideramos transcrição, aqui, o texto que reproduz fielmente o discurso gravado, inclusive as intervenções da investigadora. Cada entrevista foi datada, e assinalados sua duração (Poirier et al., 1999, p. 58) e o local de realização. Nesse material, já substituímos o nome dos participantes pelos pseudônimos que receberam no contexto da pesquisa. Estabelecemos códigos para os vícios de linguagem, usando diferentes sinais identificados em nota de rodapé, a fim de facilitar a leitura posterior do texto e, ao mesmo tempo, manter a fala integral. ${ }^{17}$ Os trechos de leitura realizados, bem como comentários e diálogos que fugiam aos objetivos do trabalho, especialmente no primeiro e no terceiro encontros, foram suprimidos, fazendo-se a respecti-

${ }^{16}$ Como as entrevistas foram longas, especialmente a primeira e a segunda, observamos que o melhor seria transcrevê-las por partes. Assim, fizemos a transcrição de cada entrevista em blocos de meia hora; logo depois desse tempo, interrompíamos o trabalho para ouvir novamente a gravação daquele trecho, acompanhando o texto já digitado, com o objetivo de corrigir eventuais omissões e/ou equívocos. Após o término de toda transcrição, retomávamos a leitura integral do texto, já sem o acompanhamento da gravação, para ajustar a pontuação e fazer correçóes ortográficas. Foram necessárias 544 horas para a transcrição de trinta das quarenta entrevistas realizadas. Apenas duas transcrições não foram feitas pela investigadora.

${ }^{17}$ Esse aspecto é fruto de orientação oral da professora Cármen Perez, em um momento muito informal de aprendizagem, em nossa casa portuguesa, em Queluz (fev. 2006). 
va observação. Quanto à dimensão da linguagem, Poirier et al. (1999, p. 63) questionam o que fazer com os erros de linguagem e afirmam: "A fidelidade parece ser a regra mais ética, mas o excesso também pode acabar por prejudicar o sentido do que é dito". Assim, optamos por fazer apenas pequenas correçôes, relativas a equívocos de concordância. Todavia, fizemos todas as alterações que foram eventualmente sugeridas pelas professoras entrevistadas, após a leitura da transcrição integral, considerando ser delas a autoria da narrativa. Nesse caso, foi incluída nota de rodapé, ao final do parágrafo, informando que o mesmo foi revisto pela narradora. O "contrato de trabalho", contudo, deixa claro que essa revisão deve ser apenas de aspectos gerais, e não do conteúdo da fala.

Toda a trama que envolveu a transcrição das entrevistas nos levou à retomada do livro Histórias de vida: teoria e prática, anteriormente citado (Poirier et al., 1999). Se essa obra, a princípio, pareceu-nos muito técnica, pudemos perceber com maior clareza por que é citada pela maioria dos autores que trabalham com as histórias de vida em Portugal: a segunda e a terceira partes são dedicadas à "prática do inquérito". Encontramos indicativos detalhados sobre a possibilidade de tratamento dos dados das histórias de vida. O reencontro com essa leitura, já em outra etapa da pesquisa, contribuiu para a sistematização do caminho percorrido e a reflexão e o planejamento do que ainda estava proposto, não no sentido de seguir todas as etapas sugeridas pelos autores, mas fazendo as adaptações necessárias, escolhendo e reconstruindo caminhos, tanto na realização das transcrições como na análise de conteúdo.

Apreensão do diálogo, da interlocução: contexto das entrevistas, gestos, entonações, emoçôes...

Dedicamos este espaço para o relato do processo das entrevistas na experiência vivida com as professoras. Este relato busca fonte, especialmente, nos registros informais do livro da vida, escritos após cada encontro, anteriormente ao processo de transcrição.

O calendário das entrevistas, quanto aos dias e horários, foi sugerido pelas professoras e organizado de forma a contemplar as possibilidades delas. Da mesma forma, os locais de realização também foram definidos por elas e 
compreenderam as escolas em que trabalham, ${ }^{18}$ suas residências, ${ }^{19}$ a Faculdade de Formação de Professores da Universidade do Estado do Rio de Janeiro $(\text { FFP/UERJ })^{20}$ e a residência da investigadora. ${ }^{21} \mathrm{O}$ cronograma foi, em geral, mantido, sofrendo, em alguns casos, alterações previamente agendadas e reorganizadas. Os locais de realização foram adequados quanto à privacidade e à tranquilidade necessárias. Especialmente nas escolas, em determinados momentos, sofremos algum tipo de interrupção ou o local foi "invadido" pelos característicos ruídos da movimentação dos/as alunos/as, mas nada que comprometesse o trabalho.

Além do registro das falas, por meio das entrevistas, podemos observar e ressaltar a linguagem como movimento de todo o corpo que fala - por gestos, emoções, pausas e silêncios. Quando realizamos a análise de conteúdo, na verdade, contamos não apenas com o registro escrito, mas com a memória das interações intensamente vividas. Vivemos a experiência do diálogo e da partilha e procuramos a sensibilidade e a sabedoria que vêm do saber escutar, do se colocar no lugar do outro e procurar compreender cada narrativa do ponto de vista de seus sujeitos e contextos, desenvolvendo, ainda, o cuidado de não colocar a investigação no lugar do "julgamento", mas situá-la na intensidade da compreensão analítica, crítica e reflexiva.

\section{Movimentos da primeira análise de conteúdo}

Qual caminho tomar no movimento de análise e interpretação das narrativas? Estou no período de realização e transcrição das entrevistas, contudo, mesmo que, de forma sistemática, a análise de conteúdo vá se dar, de acordo com o cronograma, posteriormente à conclusão de todas as entrevistas, o fato é que o movimento de análise e de interpretação parece vir colado à experiência das entrevistas, estando ainda presente nas transcrições e, de forma significativa, na preparação do terceiro encontro (20 fev. 2006).

Como escrevi hoje para Débora e Célia, apesar do enorme tempo necessário às transcriçôes, sinto-me cada dia mais 'encantada' com o aporte (auto)

\footnotetext{
${ }^{18}$ No caso de cinco professoras portuguesas.

${ }^{19}$ No caso de seis professoras, sendo duas portuguesas e quatro brasileiras.

${ }^{20}$ No caso de uma professora brasileira.

${ }^{21}$ No caso de uma professora brasileira.
} 
biográfico. A organização do material das entrevistas da professora Paula, a tentativa de primeira análise de conteúdo, foi um movimento que empolgou e emocionou. Pensar na vida, na tensão e nas contradições de sua dinâmica; enfim, pensar na formação é o que vem marcando o sentido de meu envolvimento com este trabalho (4 mar. 2006).

Após a realização de cada entrevista, seguiram-se o registro informal, a transcrição e a primeira análise de conteúdo, distribuída em três etapas. A primeira etapa consistiu na análise centrada em cada uma das entrevistas, incluindo: a criação de um segundo arquivo com a narrativa (tendo em vista que o primeiro refere-se à transcrição integral); inserção, nesse segundo arquivo, de duas colunas; na coluna à direita, o texto integral da transcrição - que foi, posteriormente, marcado com diferentes cores, de acordo com as temáticas e categorias abordadas -, e na coluna à esquerda, sinalização dos eixos temáticos focalizados pela narrativa. As sinalizações da coluna à esquerda seguiram as indicações do roteiro; entretanto, foram inseridas a partir da releitura do texto, respeitando-se os desdobramentos relativos a cada narrativa, em que demarcamos o percurso vital, as grandes etapas, os acontecimentos importantes, as pessoas, os contextos sócio-históricos e geográficos, assim como assinalamos algumas expressões e referências recorrentes na fala da professora.

Posteriormente à realização das duas primeiras entrevistas, foi realizada a segunda etapa da análise, em uma perspectiva de articulação das narrativas. ${ }^{22}$ A realização do "ensaio" com a primeira professora participante foi fundamental no delineamento metodológico, possibilitando especialmente a sistematização do caminho a ser trilhado na análise de conteúdo.

Buscando sistematizar a análise da narrativa, organizamos um "roteiro temático-cronológico", ${ }^{23}$ que, em uma tabela, apresenta os seguintes itens, distribuídos em colunas: desdobramentos temáticos: memória das experiências pessoais, familiares e contextuais; memórias da trajetória de

\footnotetext{
${ }^{22} \mathrm{O}$ objetivo dessa sequência de açóes foi garantir que o terceiro encontro com as professoras fosse dedicado ao movimento de interpretação partilhada, já que para isso fazia-se necessário que as professoras recebessem cópia das transcrições para leitura e análise, bem como que a investigadora já tivesse uma primeira reflexão, a fim de intercambiar pontos de vista com as professoras.

${ }^{23}$ Cf. anexo 6.
} 
aluna, formação inicial, formação contínua; definições e imagens sobre a docência e memórias das experiências profissionais; pessoas - chave e contexto sócio-histórico-geográfico. No final da montagem do roteiro temático-cronológico relativo à narrativa da professora Paula e da leitura das diversas colunas, percorrendo cada uma das etapas da vida (infância, juventude e vida adulta), inserimos mais uma, com a indicação dos acontecimentos biográficos, acontecimentos que constituem o centro do processo formativo, ou seja, da própria biografia educativa.

Quanto à presença de expressóes e temáticas recorrentes, o desenvolvimento da investigação-formação possibilitou perceber o delineamento de diferentes dimensões das narrativas construídas pelas professoras. Fomos, então, procurando identificar essas temáticas em cada uma e "copiando" do texto as passagens representativas das mesmas e, assim, montamos um documento que chamamos de "recorrências temáticas", agrupadas em torno dos seguintes eixos: formas de ser e de estar, movimentos da memória e da narração, concepções e definiçōes da docência, concep̧̧ōes de formação, reflexōes críticas e contextuais, análise comparada entre educação antiga e educação de hoje, reafirmação do desejo de continuar na docência e caracterização da infância hoje. Nesse processo, lembramos a contribuição da análise do professor doutor António Neto, quando, na discussão do roteiro, afirmou a necessidade de que a análise não ficasse presa a um esquema padrão, mas pudesse fazer aflorar a diversidade de construções que se dão na narrativa. $\mathrm{O}$ desenvolvimento da análise dessas recorrências temáticas aponta justamente esse fato, pois, se algumas estão presentes em todas as narrativas, outras foram identificadas em umas e não em outras.

Após as análises e a organização do "roteiro temático-cronológico" e do documento com as "recorrências temáticas" - que traduzem um processo de detalhamento e explicitação dos acontecimentos centrais da trajetória de vida das professoras -, tomamos o "roteiro com tópicos para reflexão", entregue às professoras juntamente com as transcrições dos dois primeiros encontros, e elaboramos um pequeno texto, refletindo sobre cada tópico e, especialmente, sinalizando os sentidos da formação para cada uma delas. Nesse momento, buscamos um olhar global e compreensivo sobre a narrativa, em um processo de articulação da tessitura.

Com a elaboração dessas análises, partimos para a terceira etapa, que consistiu no último encontro com as professoras, dedicado à análise parti- 
lhada da narrativa. Tratou-se de um momento especialmente significativo de diálogo e de formação para as professoras e para a investigadora, em uma circularidade de vozes e polifonia de interpretações. Inicialmente conversamos sobre as impressões gerais a respeito da transcrição, quando, em alguns casos, as professoras solicitaram alteração e/ou revisão de determinados trechos. A seguir, apresentamos o "roteiro temático-cronológico", por meio da leitura da coluna dos acontecimentos biográficos, e o documento com as "recorrências temáticas". Esse foi um momento importante, no qual algumas dúvidas da investigadora puderam ser sanadas e em que novas narrativas e histórias surgiram complementando os relatos anteriores. Partimos, portanto, para a discussão acompanhada de reflexão sobre os tópicos, já analisados anteriormente, tanto pela professora como pela investigadora e, finalmente, para o preenchimento do "gráfico de experiências instituintes", pela professora.

Ao contrário dos recursos anteriores, o esquema desse gráfico foi organizado logo no início do planejamento do trabalho. Seu objetivo é registrar a importância dos diversos acontecimentos biográficos no decorrer da infância, juventude e vida adulta, nas diferentes dimensões formadoras, ou seja, nas memórias pessoais, acadêmicas e profissionais. Os itens destacados na coluna dos "acontecimentos biográficos" do "esquema temático-cronológico” foram recortados e levados separadamente, bem como o esquema vazio do gráfico; assim, no terceiro encontro, cada professora montou seu gráfico, demarcando a relevância dos diversos acontecimentos de sua trajetória. ${ }^{24}$ São esses os movimentos que constituíram a dinâmica do que chamamos primeira análise de conteúdo.

\section{Movimentos da segunda análise de conteúdo}

A primeira análise de conteúdo foi desenvolvida em uma perspectiva "vertical", olhando a trajetória de cada uma das professoras em sua singularidade; na segunda, buscamos o diálogo entre elas, em uma "análise horizontal”, tomando como referência a especificidade das categorias centrais da presente investigação e de seus desdobramentos em eixos temáticos. Para favorecer essa dinâmica, organizamos diferentes quadros comparativos.

${ }^{24}$ Cf. anexo 7. 
Inicialmente, sistematizamos os dados sobre a data de nascimento e a escolarização dos pais, data de nascimento das professoras e dos contextos históricos em que realizaram a escola primária, apenas colocando as informações lado a lado, favorecendo a análise relacional entre elas. Para o estudo comparativo da configuração das biografias educativas, organizamos quadros, inserindo lado a lado a sequência das etapas e fases de vida e formação das professoras portuguesas e brasileiras.

O desenvolvimento da análise foi mostrando que o "esquema temático-cronológico" de cada uma das professoras constituía uma fonte básica de pesquisa, pois neles encontramos a síntese das trajetórias e, quando necessário, partíamos de seus tópicos para a releitura do trecho correspondente na transcrição integral das entrevistas. A consulta ao esquema, entretanto, começou a concentrar-se especialmente na coluna dedicada aos "pontos centrais da biografia educativa”, que sintetiza os principais acontecimentos biográficos destacados pelas professoras. Assim, tendo em vista facilitar a visualização, partimos para a montagem do "quadro de análise comparativa entre os pontos centrais da biografia educativa". Nesse quadro, colocamos em uma tabela de seis colunas os pontos centrais das biografias educativas das professoras, extraídos do quadro temático-cronológico, sendo uma tabela para as professoras portuguesas e outra para as brasileiras, visando favorecer uma leitura de conjunto. Para o desenvolvimento da análise, relemos e marcamos, com diferentes cores, os acontecimentos ligados às dimensóes pessoais, acadêmicas e profissionais, já que constituem desdobramentos temáticos fundamentais aos objetivos propostos pela investigação. Esse material permitiu analisar cada um dos referidos eixos, em um diálogo entre as diferentes trajetórias.

Visando perceber as ênfases temáticas nas diferentes narrativas de acontecimentos ligados a cada uma das dimensóes, fizemos a contagem dos mesmos, em uma tabela destinada à análise comparativa da frequência entre os pontos centrais da biografia educativa. A introdução desse procedimento de análise quantitativa mostrou-se necessária e pertinente ao desenvolvimento da análise, especialmente na visualização de dados. É importante destacar que, no contexto do referencial teórico-metodológico e interpretativo-crítico em que nos apoiamos, entendemos que, assim como todos os demais recursos utilizados, a análise da frequência favorece a possibilidade de uma dentre tantas outras perspectivas interpretativas. 
O caminho metodológico desenvolvido na análise de conteúdo tomou como referência, especialmente, as contribuições de Poirier et al. (1999) e Ghiglione e Matalon (2001). O estudo da metodologia de análise de conteúdos, com base nos referidos autores, possibilitou a adaptação e a reconstrução dos caminhos necessários à especificidade da análise proposta nesta investigação. Desenvolvemos uma análise que consideramos intermediária entre procedimentos fechados e abertos. Segundo Ghiglione e Matalon (2001, p. 181), nos primeiros, há um quadro de categorias de análise estabelecido previamente que não pode ser modificado, enquanto nos outros as categorias surgem a partir da análise dos próprios textos. Aqui, tomamos como referência ampla da análise os objetivos da investigação - que sistematizamos em eixos temáticos referidos a três dimensōes da formação docente, a pessoal, a acadêmica e a profissional -, detalhados no roteiro da entrevista. $\mathrm{O}$ desdobramento temático de cada um deles, contudo, não foi definido previamente, mas emergiu, como vimos, da análise das transcriçôes integrais das entrevistas biográficas, abrindo caminhos para a análise de questões não planejadas previamente.

\section{Reflexóes}

Este capítulo aponta a perspectiva da pesquisa como processo desejado, intensamente planejado, mas construído no caminho, no caminhar. Conta a história de uma aventura luso-brasileira cheia de trilhas e vielas, de dores e delícias, indicando o sentido do trabalho acadêmico e científico que entrelaça a paixão e a construção do conhecimento que se dá no enfrentamento da vida como desafio e na abertura ao outro. Nas palavras de Clara, uma das professoras participantes, conhecimento que acontece quando deixamos a porta aberta para mais um entrar e com ele aprendemos e ensinamos. 


\section{Capítulo 6 \\ Trajetórias de vida e formação de professoras portuguesas e brasileiras: suas biografias educativas}

Após o percurso sobre as principais etapas da investigação-formação, passamos à apresentação da trajetória de vida e formação de duas ${ }^{1}$ professoras participantes. Inicialmente, tecemos uma reflexão sobre as aprendizagens que vieram pela experiência narrativa vivida com as professoras. $\mathrm{O}$ movimento de voltar e deter o olhar nas experiências vividas com as professoras nos três encontros nos possibilitou identificar importantes reflexões e aprendizagens que se deram ao longo da pesquisa, na problematização da abordagem (auto) biográfica, especialmente por meio de entrevistas.

O segundo momento é dedicado à narrativa da história de vida das professoras, de suas biografias educativas, pelo enfoque no processo de formação tecido ao longo da trajetória, articulando dimensóes pessoais, familiares, acadêmicas e profissionais. O caminho para a escrita deste texto foi, inicialmente, a retomada das transcriçôes das entrevistas de cada professora, no quadro da primeira análise de conteúdo, ou seja, fomos guiados pelos trechos marcados em diferentes cores, acompanhando a síntese temática colocada ao lado. Posteriormente, tomando o esquema temático-cronológico, o texto foi construído tendo como referência inicial o acontecimento biográfico ou a etapa da vida tomados pela própria narradora como ponto de partida,

1 A tese que originou este livro contém a biografia educativa das 12 professoras participantes. Aqui, por necessidade de redução do texto para publicação, registramos apenas duas. 
buscando referenciar o sentido da biografia educativa pela centralidade das experiências formadoras tecidas ao longo da vida. O fio condutor, portanto, colocou-se sobre o processo formador, as pessoas, os acontecimentos, os lugares e os contextos que geraram aprendizagens e formação.

Senti grande prazer em escrever as biografias educativas das professoras; para mim, é o que de mais especial a pesquisa vai conter. Me emocionei relendo e reescrevendo as histórias e a experiência de memória e formação que vivemos juntas durante as entrevistas. Coloquei muitos trechos com a fala das professoras, são os seus sotaques, suas emoções que dão sentido e beleza à narrativa, uma narrativa que se fez a duas mãos, mas que se abre aos que quiserem ler e retecer as histórias contadas. No contar, as histórias foram recriadas, como também foram agora na tessitura do texto escrito. Me senti como tecelā, buscando nas transcriçôes, no esquema temático-cronológico, os fios que foram a pouco e pouco se articulando e compondo um mosaico multicolorido, cores cinzentas, cores alegres, indicando apenas uma dentre tantas possibilidades de leitura e interpretação (23 set. 2007).

\section{Encontro com as professoras: a diversidade de movimentos narrativos}

Tomamos as anotações do livro da vida como fonte de análise da particularidade e dos indícios que vêm dos movimentos da memória e da narração, reflexões sobre o processo narrativo de cada professora. Então, buscamos favorecer a emergência de anotaçóes produzidas logo após o momento de realização das entrevistas e que oportunizam a entrada no contexto da experiência narrativa, assim como ressaltam questóes que surgiram ao longo do percurso e que nos permitiram significativas aprendizagens relativas ao próprio aporte (auto)biográfico. São essas aprendizagens que procuramos analisar neste item.

$\mathrm{Na}$ reflexão sobre o processo, podemos identificar aproximações dos movimentos da memória e a narrativa no encontro com cada professora. Observamos esses movimentos tanto no próprio momento da entrevista quanto depois, na transcrição e na análise; no primeiro, observamos a força e a pulsão que envolvem a vida e sua expressão por meio da narrativa e, no segundo, a tentativa de compreender o entrelaçamento de diferentes fios que se articulam de forma complexa e não linear. No conjunto dessa reflexão, percebemos que há um fluxo narrativo que é peculiar a cada professora e que traz indícios de 
seu envolvimento não só com a investigação, mas também com sua forma de ser $e$ de estar no mundo; são diferentes os recursos da memória para trazer acontecimentos, pessoas, lugares que marcaram a trajetória, dando uma forma, reconstruindo uma história articulada e que tenha sentido, sendo, de fato, reorganizada pelo narrador. É como tomar a vida para ressignificá-la, de forma inteligivel, no contexto presente.

Observamos que algumas professoras desenvolveram uma narrativa tranquila, serena, e se deixaram conduzir por temas e questóes introduzidas pela investigadora. Em outros casos, o fluxo narrativo foi dado pelas próprias professoras. A partir dos objetos levados ou por meio da eleição de um acontecimento biográfico, iniciaram a narrativa, percorrendo suas trajetórias de vida e formação. Algumas levaram concretamente seus objetos significativos, outras simbolicamente, ou seja, narraram quais objetos levariam, caso tivessem oportunidade. Nas duas situações, percebemos que esse foi um recurso que enriqueceu a narrativa, contribuindo no sentido da ruptura cronológica e fazendo emergir acontecimentos biográficos que, em alguns casos, traziam um fio condutor ou uma possibilidade de leitura da história de vida, tais como: a fotografia de sua turma, no caso de Ana; os cadernos do ensino primário de Teresa; a "cana da professora" de Isabel; as fotografias e o broche da avó de Hélida; a "cesta de memórias" de Rute; e o cubo de Simone.

A singularidade dos movimentos narrativos também nos permitiu perceber que, em diferentes momentos, cada uma, espontaneamente, foi falando sobre sua forma de ser e de estar no mundo como pessoa e professora, sentidos atribuidos à identidade pessoal e docente. É interessante ainda observar que cada professora estabeleceu, internamente, certo limite possivel de doação ou de expressão de sua narrativa, e foi a intensidade dessa expressão que nos permitiu a profundidade e os elementos da análise.

Podemos afirmar que houve um efetivo envolvimento e um compromisso de todas as professoras participantes, mas estes se deram de forma naturalmente peculiar para cada uma. Enquanto percebemos o envolvimento imediato de algumas, outras foram construindo a relação com a pesquisa gradativamente ao longo do processo, em cada um dos encontros. Observamos que, se, por um lado, a possibilidade do envolvimento das professoras com a investigação relaciona-se, nomeadamente, à compreensão do sentido da investigação e de sua própria participação, ou seja, quanto mais clara a natureza do trabalho proposto, maior o envolvimento; por outro, de manei- 
ra geral, o conhecimento prévio, ou mesmo uma relação anterior estabelecida entre a investigadora e a professora, parece que veio favorecer essa dinâmica. Entretanto, em vários casos, o relacionamento foi estabelecido em função da pesquisa, e houve, de forma imediata ou gradativa, um intenso envolvimento com a investigação.

Mas o que chamamos efetivamente de envolvimento, já que este é um conceito essencialmente subjetivo? Consideramos envolvimento a possibilidade de que a participação no processo de investigação-formação não se coloque para a professora como um compromisso a cumprir, mas que se traduza em experiência, reflexão e, potencialmente, formação. Olhando nessa perspectiva, podemos afirmar que pelas narrativas orais das professoras, especialmente no momento de avaliação da investigação, realizada no terceiro encontro, e pelas narrativas escritas e posteriormente encaminhadas, a investigação constituiu um momento significativo e que, de alguma forma e em diferentes medidas, "tocou” não só as professoras participantes, mas também a investigadora.

Para concluir este momento de análise dos indícios da memória e da narração presentes na experiência vivida com as professoras, trazemos uma das dimensóes fundamentais de nosso estudo: a especificidade formadora do aporte (auto)biográfico. Em que medida uma metodologia centrada em entrevistas biográficas pode produzir uma dialética entre conhecimento e formação? Observamos que a dinâmica narrativo-reflexiva envolveu tanto as professoras como a investigadora, em caminhos que se foram abrindo aos poucos, afirmando a professora-investigadora como narradora e a professora-narradora como investigadora.

A dimensão narrativa colocou-se para as professoras pela partilha da história de vida e para a investigadora que, como acompanhante, interagiu com cada professora, com cada história partilhada, vivendo junto um processo de reconstrução, ressignificação. Nesse sentido, a presença da investigadora não é isenta; marca, entretanto, o lugar de alguém que traz encaminhamentos e questôes e que influencia o desenrolar narrativo, participando de uma construção dialógica. Instaurou-se, em cada encontro, uma dialética entre os momentos formais e informais: no tempo formal da entrevista, marcado especialmente pela presença do gravador, percebemos a busca de uma circularidade dialética entre escuta sensível e o falar em tempo oportuno; e nos momentos informais do café ou nas conversas antes e após as grava- 
ções, a interação entre nossas histórias e, em muitos instantes, a narrativa da investigadora sobre lampejos de sua trajetória de vida e formação, bem como travessias da docência nos anos iniciais do ensino fundamental. Assim, professoras e investigadoras assumiram, em diferentes intensidades e dinâmicas, o lugar de narradoras, reafirmando o sentido de uma narrativa aberta, dialógica e partilhada que reconstrói histórias, sentidos e interpretaçôes. Dessa forma, a reflexão articula-se, indissociavelmente, à narrativa. Vivenciamos momentos importantes de reflexão sobre a trajetória de vida, que ultrapassam os encontros realizados, porque proporcionam a incorporação, por parte das professoras, das reflexões pessoais tecidas antes e depois de cada entrevista, a leitura/revisão das transcrições e a avaliação escrita e, ainda, por parte da investigadora, das reflexões ao longo do processo, da escrita do livro da vida, das horas dedicadas às transcriçôes e análises. Nessa dinâmica narrativo-reflexiva circularmente virtuosa, encontramos o potencial formativo da tematização temporal e partilhada da vida; potencial porque uma formação que, se pode ser percebida por indicios e sinais, não pode e não se deseja "medida" ou "quantificada".

Em algumas professoras, percebemos e apreendemos nos gestos, na intensidade narrativa, em suas vozes traduzidas nas transcriçóes e, posteriormente, nos textos escritos, a importância do momento narrativo-reflexivo na reelaboração de suas histórias, de suas imagens, o que indicou um processo potencialmente formador. Algumas dedicaram especial tempo ao preparo de sua participação na investigação-formação, na cuidadosa seleção do objeto significativo, na elaboração escrita de textos, como fez Carolina, ou até na retomada narrativa de suas "crônicas", como fez Hélida. Movimentos que indicam uma reflexão que vai transbordando do espaço-tempo formal da pesquisa. Também o terceiro encontro, com todas as professoras, colocou-se como marco de um processo formativo partilhado, em que intercambiamos pontos de vista, em uma reconstrução conjunta da narrativa, de seus múltiplos fios e marcos.

Observamos que a partilha das histórias de vida nos aproxima das pessoas, nos faz criar vínculos que também ultrapassam a dimensão da pesquisa, envolve emoção e afetividade. Como disse Josso (1988b), o pesquisador precisa ser um "amante"; é preciso amar as histórias de vida, mas essencialmente as pessoas, aprender a partilhar o riso e, muitas vezes, o choro, as dimensões presentes na experiência da entrevista biográfica. 


\section{Trajetórias de vida e formação das professoras: biografias educativas}

Desde o iniciar do trabalho com as professoras, nutri forte expectativa de que pudesse encontrar nele, ou seja, nas próprias narrativas, o sentido da investigação; tinha os objetivos, eixos e questôes, contudo, queria estar atenta ao movimento interno da própria pesquisa, às pistas que vêm do desenvolvimento do trabalho, que vêm da voz das professoras. E uma das pistas que vai-se tornando forte é a possibilidade de aprender com a história de vida delas. Ter acesso às suas biografias educativas, às suas histórias, aos caminhos percorridos tem-me ensinado e tem-me feito refletir sobre minha própria trajetória (19 abr. 2006).

As biografias educativas das professoras são um convite à aprendizagem; aprendemos de maneira especialmente significativa quando ouvimos suas vozes falando da vida em cidades, aldeias e vilas em Portugal e no Brasil, das genealogias e histórias de família que atravessam um tempo saturado pelos contextos sociais, históricos e políticos em que estão inseridos, como o "25 de Abril" e a "ditadura militar", das memórias da escola primária e do desenrolar da escolarização, dos encontros e desencontros com a docência e a materialidade de seu trabalho, das pessoas, dos outros, muitos outros com quem, ao longo da vida, ensinam e aprendem. Em cada uma dessas histórias, uma possibilidade de narração e também de leitura se coloca, em um movimento sempre aberto que, agora, envolve também o leitor no compromisso de reflexão não só sobre a tessitura da intriga que se coloca nas tramas dessas duas professoras, mas também, e especialmente, na possibilidade de, ouvindo e refazendo essas histórias, refletir e refazer também, dialogicamente, lampejos de sua própria trajetória de vida e formação.

\section{Clara: ${ }^{2}$ a formação como caminho de encantamento e curiosidade}

Eu venho de uma família humilde [...] minha mãe me conta que a minha bisavó era de uma família muito rica e apaixonou-se por uma pessoa, pelo meu bisavô, que era uma pessoa muito pobre [...] Como ele não tinha muito, pronto, não tinha dinheiro, na altura, ainda no século XIX, foi para o Brasil

\footnotetext{
2 Professora portuguesa.
} 
fazer fortuna [...] Eles namoravam às escondidas, ele foi para o Brasil, e ela ficou grávida. Que que acontece? Meu bisavô morreu no Brasil com malária; portanto, a minha bisavó, ao fim e ao cabo, foi posta de lado pela família e criou a minha avó sozinha, com a ajuda de um familiar que era padre [...] e ajudou, ao longo da vida, ela a criar esta filha, que é a minha avó, mãe da minha mãe, avó materna. Pronto, a minha avó cresceu, é uma família humilde com muitas dificuldades, porque na altura as pessoas tratavam mal a minha bisavó por causa disso.

Em finais da Primeira Guerra, ser mãe solteira foi uma marca complicadíssima, mas a avó cresceu e frequentou a escola primária, fez até o $4^{\circ}$ ano, "e o tal padre ajudava-a muito nos estudos e cultivou nela o gosto por ler". A avó de Clara começou a ganhar a vida fazendo bordados, era a fada do lar. Ela se casou e teve nove filhos: "Uma família com bastantes dificuldades económicas numa altura de fome; portanto, na Segunda Guerra, minha mãe fala do tempo que passou fome. E a minha mãe aprendeu muito com a minha avó [...]". Aprendeu a costura, tornou-se costureira e aprendeu também o gosto pela leitura. O pai de Clara era empregado têxtil, casaram, estiveram um tempo em Portugal e, depois, emigraram para a Alemanha. Tiveram três filhos, Clara é a mais nova, havendo uma grande diferença de idades. Por problemas de saúde de sua mãe, retornaram da Alemanha quando Clara ainda era muito pequena: "Minha mãe tem também a quarta classe e tem uma grande paixão pelos livros, que vem desde a minha bisavó: bisavó, avó e mãe”.

A infância se passou numa Aldeia muito tranquila, onde até hoje mora. Sempre teve hortas, coelhos, patos, galinhas: "Temos o nosso próprio chá, temos chá de cidreira, mesmo nosso, e a salsa, e apanhar a salsa, o limoeiro, brincar no quintal, também brinquei, ler no jardim, lia muito no jardim, pronto, tem aquele clima $[\ldots .$. ".

[...] Uma salsa de meter inveja, toda a gente pedia salsa, eu levava os raminhos de salsa, as cenouras, também chegamos a ter cenouras; os feijōes, os tomates e as alfaces, portanto temos sempre uma hortinha ali, e os ratos que estragam tudo e tal, sempre um problema. Portanto, sempre tive esse contacto com o campo, uma aldeia sossegada. 
No ambiente familiar, Clara sempre recebeu muita atenção e cuidado dos pais, aprendeu com eles a importância do trabalho. Como os irmãos eram muito mais velhos, não brincaram juntos, mas eles a protegiam, especialmente o irmão, e a irmã a ajudava na escolaridade.

Ela influenciou-me bastante. Porque é assim, a minha irmã é mais velha do que eu oito anos, e eu sempre vi a minha irmã como uma boa aluna, a referência para mim [...] Ela influenciou-me muito em várias vertentes, desde a maneira de estar, se bem que eu sou muito mais desorganizada do que ela [...] O meu início da leitura eu não aprendi com a professora, eu aprendi com a minha irmã, a minha irmã ajudava-me muito nos trabalhos de casa [...].

A irmã torna-se educadora, ensina-a a ler e a escrever, acompanha as tarefas escolares, influencia em sua paixão pela arte e pelos livros. "Porque ela estava mesmo comigo, conversava, havia coisas que eu já sabia, mas ela mesmo assim conversava, puxava por mim”. Quando Clara tinha dez anos, a irmã foi para Lisboa, fazer o curso de design, e ela precisou aprender a caminhar sozinha: "Isso para mim foi um grande choque, porque eu aí é que me apercebi o quanto é que eu estava ligada, eu chorei muito, eu lembro". Nos finais de semana, estavam juntas e eu via os trabalhos dela: "Foi aí, se calhar, que eu fiquei muito vocacionada para Arte, para pintura, porque ela pintava, ela desenhava e as cores de pastel [...]". "Portanto, aprendi muito por causa dela e o gosto que eu tive pela história da arte eu acho que foi ela, não sei quando é que começou, mas deve ter sido por aî".

A experiência na escola de $1^{\circ}$ ciclo traz marcas e memórias fortes. Sua professora tinha sido também professora de sua irmã que era excelente, ganhou o prêmio de melhor aluna. Clara já foi para a escola preocupada: "Eu estava com medo de não ser tão boa como a minha irmã”. Por outro lado, a irmã a alertou: "Olha que ela é má, cuidado que ela [...]". "Havia o mito que ela, quando vinha vestida de vermelho para a escola, era quando estava maldisposta [...]".

Ela era uma pessoa nova, ela era nova, tinha vinte e poucos anos, estava no início de carreira, quer dizer, não estava no início de carreira, mas já tinha uns anos de prática, mas era uma professora antiga, a antiga portuguesa, ao fim e ao cabo, porque ela era nova, mas uma professora completamen- 
te ultrapassada, completamente antiquada, régua, tudo um rigor. Era uma professora autoritária, má, afectividade não existia, a minha sorte é que eu era a irmã da Margarida, que era a minha irmã que ela conhecia [...] E, depois, ela dividia a turma, para além do terror que batia forte e feio, ela dividia a turma. Era assim, quem estava à frente, nas filas, eram os melhores alunos, todo o resto que estava para trás eram os alunos que não prestavam. Portanto, ela puxava pelos melhores alunos, e quem não era bom aluno estava lá para trás, estava lá num canto esquecido e era nesses miúdos que ela descarregava mais, portanto. Eu não posso dizer que ela batia-me muito, o que mexia comigo era a injustiça [...]

Os melhores alunos tinham um tratamento especial e eram tomados como exemplos; os demais sentavam-se atrás e eram relegados. A reza fazia parte da prática diária, e era preciso total atenção, olhar direcionado ao crucifixo, caso contrário, levavam reguadas. $\mathrm{O}$ que havia era o ensino memorizado, as aulas expositivas, o tema das composições definido pela professora, um excesso de trabalhos de casa, a grande distância e a não preocupação com a aprendizagem dos alunos. A escola torna-se para Clara uma obrigação, era um castigo estar ali. "A única coisa boa que eu acho que ela fazia, não tinha só pontos negativos, é que ela, aqueles meninos que não podiam pagar os livros, ela oferecia os livros, ela pagava o material e pagava os livros".

A passagem para o 5a ano foi um alívio para Clara, ela começou a gostar da escola, descobriu o prazer de aprender e a paixão pela história: "Os reis, as rainhas, os castelos, para mim tinha uma paixão muito grande pela história e a partir daí comecei a ler livros". "Aí é que eu tive a paixão pela escola, porque tinha mais professores, havia diferentes disciplinas, aquilo era novo para mim e aí é que eu comecei a gostar das coisas e aprender. Até aí, era tudo muito morno, muito morto, eu não gostava". Na escola, descobriu as pirâmides do Egito e a história da arte, fortalecendo seu interesse pelas humanidades. Teve alguns professores que a cativaram, como a de geografia, uma professora disponível, que gostava de ouvir os alunos, de entrar no universo deles, puxar seus interesses, que procurava um ensino contextualizado nos acontecimentos da atualidade. Lembra que numa atividade a professora deu contribuição a diversos grupos da turma, era boa pessoa e boa professora, ponderada, calma. Como aluna, Clara tornou-se exigente, gostava de fazer as coisas sozinha, fazia leituras solicitadas, gostava de perceber. 
Nesse contexto, sua adolescência foi tranquila, um momento de encantamento pela leitura. Em sua escola primária não teve hora do conto, momento do livro, não havia nenhuma biblioteca, o único livro era o manual, "com aqueles textos e pronto. Lembro-me de folhear o manual e a primeira coisa que me interessou muito foram as ilustrações, tinha um manual com umas ilustrações, que me chamava atenção, ainda o tenho". Ela não tinha nenhum gosto pela leitura. Depois, quase no final do $1^{\circ}$ ciclo, começou a perceber os caminhos de leitura de seu irmão, grande leitor de banda desenhada: ${ }^{3}$ "O meu irmão era um leitor de banda desenhada, o Homem-Aranha, tinha lá em casa muitos livros de banda desenhada, não era muito comum na altura as pessoas lerem banda desenhada”.

Enquanto isso, também a minha irmã era mais para os contos infantis, a Branca de Neve, os contos tradicionais portugueses também, pronto. Depois, e eu não lia banda desenhada, mas via lá em casa, era muito [...], a minha mãe lia muito e o meu pai lia também o jornal, lia muito também. Eu não tinha muito esse gosto, por causa, se calhar, por causa da minha professora, não sei [...] No final do $1^{\circ}$ ciclo, descobri os livros da Agatha Christie e aí comecei a ler livros da Agatha Christie e, assim, comia-os todos, lia-os todos, depois passei para o Sherlock Holmes e a partir daí saltei, ou seja, nunca peguei muito nos livros infantis [...] Comecei e, pouco tempo depois, já estava a ler Gabriel García Márquez, que eu adoro ler o Gabriel, o Mia Couto, sei lá, alguns clássicos da minha mãe, porque tinha lá em casa [...] Portanto, eu comecei logo a pegar em pesos pesados [...] portanto, nas férias, aproveitava para os ler. Ao fim e ao cabo, então, inscrevi-me cedo na biblioteca, ia muito à cidade, aproveitava para dar um passeio, para comer os croissant que são excelentes [...], então, nas férias de verão, eu, por mês, lia por aí quarenta livros ou mais! À tarde ia, passava a tarde, ia de camioneta, sozinha, ia para a biblioteca [...] a biblioteca tinha revistas, tinha livros, tinha tudo, podia ouvir música também, conheci muitas coisas lá e passava as tardes lá, ia depois buscar os meus croissant, comia lá qualquer coisa e vinha para casa, eram assim as minhas tardes [...]

3 No Brasil, usamos a expressão "história em quadrinhos". 
Nessa fase, acompanhou a dificuldade de alguns colegas com drogas e com os namoros, o que a ajudou a refletir sobre seus próprios caminhos. Seus pais se divorciaram quando tinha 18 anos, mas foi um processo encarado naturalmente. Quando concluiu o secundário, tentou ingresso para licenciatura em história da arte, mas não conseguiu, foi um choque, a interdição de caminhos que desejava, foi a primeira vez que viveu a experiência de um caminho negado. A partir daí, vieram as outras possibilidades:

Que que eu agora vou fazer? Vou concorrer para, pronto, estive a estudar o que que havia de curso e pensei, ora bem, professora do $1^{\circ}$ ciclo e lembrei-me logo da minha professora. E eu, bem, é, pode ser, vou estudar para isso, vi as universidades, era uma possibilidade, porque eu também professora não desgostava. Agora o $1^{\circ}$ ciclo para mim, pensava, lembrava-me da minha professora e pensava, 'só espero não me tornar como ela foi'. [...] Portanto, optei por ir para o $1^{\circ}$ ciclo, e depois houve uma colega minha que estava a estudar e que estava a tirar esse curso, que entrou no ano que eu não entrei e ela disse: 'Olha que interessante, estou a gostar muito, depois vais estagiar, vais trabalhar com crianças, portanto, vais tirando o curso e vais trabalhar com crianças; portanto, vai ser uma parte teórica e uma parte prática, é interessante, até podemos dividir quarto juntas'.

Durante o curso, sentiu uma abordagem essencialmente teórica, leituras descontextualizadas, muitas lacunas, mas guarda a lembrança de professoras de literatura e matemática, que desenvolveram uma abordagem prática. Nesse período, “a preparação foi eu que me fui construindo". No estágio, entretanto, vivenciou uma experiência marcante, esteve em uma escola muito complicada, em uma zona de grande toxicodependência, problemas com álcool, onde de manhã ouviam-se tiros. A professora cooperante desenvolvia uma prática pedagógica que a fazia lembrar de sua professora primária - as crianças tinham medo dela, não existia relação afetiva. Mas, contraditoriamente, a professora tinha boas ideias para os estagiários, apesar de não as colocar em prática, e foi um período de aprendizagem. Mas foi com uma aluna que uma aprendizagem muito significativa aconteceu. 
Eu ainda tinha na minha ideia que os professores têm que ter aquela postura, não de uma forma violenta como eu aprendi que eu achava isso [...], mas uma postura de distância e eu com essas crianças que quase que pediam colo e, então, comecei a estabelecer, foram elas que fizeram, me moldaram, digamos assim. Portanto, havia lá uma miúda que já tinha certa idade, já poderia estar no $5^{\circ}$ ano, mas estava ali retida há muitos anos que tinha algum atraso mental e foi essa que mais pediu carinho a mim [...] olha, eu ainda hoje me lembro dela, era um amor de menina [...] Foi ela que me fez ver que o professor não é aquele que está ali que mantém aquela postura, não, eu brincava com ela no recreio, ela vinha sempre ter comigo, oferecia-me bolachas, ela tinha sempre uma bolacha para mim; então, foi aí que me fez ver as coisas de outra forma. Porque eu também não tinha grandes modelos, pensando bem, agora analisando as coisas, não tinha modelos [...]

A conclusão do curso foi uma grande alegria para sua família, a mãe, o pai, as tias, "toda gente ficou muito contente", mas depois veio o desafio do emprego, porque "as coisas estavam mal". Realizou os primeiros concursos, mas não conseguiu colocação, iniciou sua trajetória profissional em uma escola particular, substituindo temporariamente uma professora. Lá entrou em contato com uma realidade nova: meninos filhos de pais ricos, em geral, crianças sem dificuldades, meninos felizes e sem problemas, sentiu facilidade no desenvolvimento do trabalho com uma turma de $1 \stackrel{\circ}{\circ}$ ano. Trabalhou a iniciação à leitura e à escrita por meio do método analítico-sintético, utilizando os manuais. Procurou sempre brincar com os alunos, desenvolver a expressão dramática, músicas e a articulação entre os conteúdos escolares, causando estranheza ao diretor da escola sua postura e proximidade dos alunos.

Quando concluiu o período de substituição nessa escola, estava novamente sem emprego e realizou um novo concurso, não obtendo colocação. Soube, entretanto, da luta de uma escola pública que desenvolvia uma proposta pedagógica diferenciada e estava sendo cerceada pelo Ministério da Educação e não tinha professores. Então, foi a um evento de apoio a essa escola e lá soube que estavam precisando de professores/as, ofereceu-se para ajudar e iniciou uma nova etapa de sua trajetória de vida e formação. Chegou à escola como voluntária e passou a ajudar o grupo de crianças que estava na iniciação à leitura e à escrita. Já tinha feito leituras sobre aquela instituição, ainda no período de licenciatura, mas chegou com o olhar 
curioso; ela estava cheia de miúdos, "uma confusão total, não sabia quem era quem", não havia professores/as em número suficiente, mas, mesmo nesse contexto, sentiu serenidade.

Pouco tempo depois, recebeu um convite para integrar o quadro como professora. Ficou contentíssima da vida, mas, ao mesmo tempo, cheia de expectativas.

Isso é uma escola diferente, eu vou ter que perceber como é que isto funciona, que isto não tem nada a ver com a experiência que eu tive. Eu vim de uma escola particular, completamente diferente, pronto, e vi que aqui tinha muitos meninos complicados, até era mais parecido com aquilo que eu conheci no estágio [...] Meteu-me confusão a questão deles terem o plano e ter que ir ver ao plano o que que eles estão a trabalhar. Estava habituada é a fazer as planificaçôes, era eu que fazia das aulas, portanto, a professora dizia é o tema, é as plantas e eu desenvolvia a planificação. $\mathrm{O}$ que eles fazem na data $\mathrm{X}$, às $\mathrm{X}$ horas, portanto, tudo controladinho, aqui eu vi que não havia nada disso e até fiquei contente, porque não gostava nada das planificações [...] O que mais me agradou é assim, eu não estou sozinha, portanto qualquer dúvida, tenho aqui a colega para me ajudar. Óptimo, para mim é óptimo, porque eu estava numa fase em que tinha muitas dúvidas, ainda tenho e aquela pessoa vai me ajudar a como é que se aborda isto, o que que eles fazem aqui. Portanto, tem sempre ali alguém para me ajudar [...] O que mais me entusiasmou aqui foi não estar só e a relação que se estabelecia com os miúdos. Não era aquela figura distante, fria, que mantém a ordem, limpinha, não é? Assim serena, mas de uma forma rígida, não. As professoras sentavam-se ao lado dos alunos, tratavam-se por tu, não havia muito 'oh, professora', era 'oh, Clara', não é? [...] Portanto, tem sido, apesar das condiçôes todas que a escola estava a viver, de crise, a crise, não senti aquela crise, porque eu ainda estava, para mim era tudo novo e até estava a ser bom para mim, uma experiência óptima.

Clara atuou junto com Isabel durante dois anos, com os "meninos da primeira vez", 4 sentiu muita ansiedade frente ao processo de alfabetização: "Eles não vão aprender a ler assim". Teve muitas dúvidas, mas foi crescendo, aprendendo, perguntando, lendo, procurando, questionando, ouvindo mui-

\footnotetext{
4 Alunos do $1^{\circ}$ ano escolar.
} 
to caladinha para aprender, bebendo: "Ainda estou a aprender muito, ainda tenho muito para aprender". Nesse processo de "iniciação", as imagens de sua experiência na escola primária vieram como contraponto:

Como aluna nunca imaginava que a minha professora ia sentar ao meu lado a ler comigo, nunca leu, a leitura era ela a ler na secretária e eu ali e ai de mim que eu, às vezes, até gaguejava, porque tinha medo e tremia [...] nunca tal me passou pela cabeça, portanto tudo aquilo que eu tinha, eu fui desconstruindo [...].

A escola passava por uma reestruturação e por um processo de afirmação social de uma prática educativa que se desejava instituinte e, ao mesmo tempo, Clara foi consolidando sua forma de ser e de estar na docência, passou a trabalhar com outro grupo de alunos, especialmente com a área de língua portuguesa. Como professora, procura uma relação próxima e brincalhona com os alunos: "Estar e brincar com eles, estar ao lado deles"; respeitar o ritmo e a herança das crianças, ajudar as que mais precisam, dar atenção especial a cada aluno, contribuindo para que sejam felizes e gostem de aprender. Sua paixão pela arte foi incorporada à sua prática pedagógica, na articulação de todas as áreas, por meio da música, do desenho, da cor. São grandes a responsabilidade do professor de $1^{\circ}$ ciclo e a intensidade do trabalho, há muitas correçôes que precisam ser feitas fora do horário escolar.

Ao longo de seu caminho na docência, teve o apoio de colegas com quem partilhou e aprendeu. Na escola particular, recebeu sempre apoio e, na escola em que foi trabalhar, a proximidade de Isabel e o acompanhamento de seu trabalho foram inspiradores, especialmente sua forma de brincar com as crianças e incentivar cada um no encontro de seu próprio caminho. A busca de compreender os alicerces da prática pedagógica da escola em que trabalhava a levou a um intenso processo de autoformação: "Também incidi muito tempo de estudo só para perceber como é que esta escola funciona, [...] perceber quem é o Freinet, quem é o Paulo Freire, quem é o Dewey, quem é, onde está aqui nessa prática, a importância de um plano do dia, de um plano da quinzena, da autocorrecção". Investiu muito tempo para perceber os vários métodos de leitura e escrita: "Quando uma criança não consegue atingir com determinado método, vamos tentar outro, porque todos os métodos são bons, desde que resultem, são bons [...], portanto, esta escola exigiu que eu estudasse os vários métodos de iniciação à leitura e à escrita”. Quanto à for- 
mação contínua, procura todos os anos fazer ações para se atualizar, ligadas à prática e aos desafios que encontra na sala de aula.

A teoria é fundamental, sem dúvida, eu dou importância à teoria, mas uma teoria em que se ponha em prática, não uma teoria que não me diga nada para pôr em prática, uma teoria está aliada à prática, uma prática está ligada à teoria, portanto, a prática constrói a teoria também, portanto, as duas coisas não estão separadas [...]

Da vida de Clara, pulsa a formação. Em um movimento sereno e sossegado, tal como o clima de sua aldeia, somos conduzidos pela narrativa ao encontro de uma menina estudiosa, uma adolescente leitora e uma jovem professora pesquisadora, em uma diversidade de experiências guiadas pelo encantamento e pela curiosidade.

$\mathrm{Na}$ infância, a afetividade e a intensidade do ambiente familiar formador contrapõem-se ao rigor, ao conservadorismo e à frieza das práticas da escola primária, com a força e o sentido da interdição da aprendizagem, transformada em obrigação e castigo. Entretanto, a história de leitoras da família, passando por bisavó, avó, mãe e irmã, inicialmente sufocada pela escolarização, manifesta sua presença e, no final da infância, Clara se vê fisgada pela leitura. De um processo de formação morno e morto, a adolescência vai conduzindo à descoberta do prazer da aprendizagem: a história da arte e a literatura como paixões, tardes na biblioteca a devorar livros! Em seu caminho de formação, encontramos uma irmã educadora, é com ela que aprende a leitura e a escrita, o gosto pela arte e o incentivo no percurso como leitora. A separação, quando a irmã se muda para estudar, é sofrida, mas constitui um importante momento de autonomização de seu percurso de formação, Clara fortalece sua forma de ser e estar como pessoa, estudante, mas, sobretudo, como aprendiz.

A interdição de uma escolha profissional traz um sentimento novo: a frustração, o não alcançar um objetivo almejado, gera tristeza e decepção; indica, contudo, uma aprendizagem importante - os planejamentos nos escapam, é preciso estar sempre pronto para reorganizar projetos de futuro. É no movimento de reorganização que Clara se encontra com a docência de 
$1^{\circ}$ ciclo, reafirmando, contudo, que nunca gostaria de ser como sua professora primária.

Apesar de desejar construir sua prática educativa em outras bases, a força da referência sobre a docência sinalizava o distanciamento entre professor e aluno e, nesse momento, é uma aluna educadora que, no contexto do estágio, rompe as barreiras, mostrando que ensinar e aprender exigem proximidade e "amorosidade". Clara deixa sempre a porta aberta para alguém entrar e ensinar-lhe, a aluna educadora conduziu o encontro com a imagem que buscava e é essa imagem que procura traduzir em prática docente.

No caminho da docência, uma escola educadora, com colegas educadores e alunos educadores, na qual se partilha a construção de uma prática educativa comum. Ali, também movida pelo encantamento e pela curiosidade, tem construído um caminho de autoformação partilhada. Toda sua trajetória se desenrola no ambiente de aldeia, em contato direto com a natureza, a relação de cordialidade e partilha com a vizinha. Esteve em outra cidade apenas durante quatro anos, para a realização da licenciatura.

Dentre as dimensões formadoras da trajetória de Clara, destacam-se a formação familiar, a aprendizagem do valor do trabalho e do estudo na construção da vida e a força de uma geração e um ambiente de leitores. Além disso, as experiências profissionais como fontes permanentes de questionamento e curiosidade, despertando um caminho de autoformação partilhada com colegas e alunos.

\section{Simone: 5 a formação como movimento, pesquisa e experimentação}

[...] lembrei do meu cubinho, que é um porta-retrato e que era da minha tia [...], em que eu troco as fotos de acordo com os momentos da minha vida. Então, esse cubinho já teve foto quando era neném, depois teve foto da minha infância, depois teve foto de namorado, depois teve foto de alunos, de amigos da escola, já teve cada quadradinho algum amigo. Já fiz uma vez só foto minha com a minha melhor amiga. Então, assim, é um cubinho que eu vou trocando de acordo com o meu momento. E que atualmente eu voltei às fotos minhas de quando eu era criança [...] E que daqui a pouco elas vão ceder lugares pra fotos da Marina [...] Algumas fotos estão cortadas, então,

\footnotetext{
5 Professora brasileira.
} 
quando eu mexo na caixa de fotos, eu sei quais estiveram presentes no cubinho. Então algumas fotos que já não são mais significativas: crianças que eu dei aula, a minha primeira turminha, já não voltarão, eu sei que não voltarão mais, e fotos que talvez [...] O meu primeiro cachorro. Então, assim, já teve tudo diante do meu cubinho.

Do mosaico de lembranças da infância, a imagem de tempos de recolhimento, não guarda saudade do sítio onde morou durante 23 anos: "Eu não tenho saudade da minha infância. Eu acho que eu sou muito mais feliz agora do que quando eu era criança”. Quando Simone nasceu, sua mãe tinha apenas 19 anos. Logo depois seus pais se separaram, e sua mãe se casou novamente. Moravam em uma cidade serrana e no mesmo terreno havia duas casas: numa, moravam Simone e a avó, e, na outra, a mãe, o padrasto e a irmã, seis anos mais nova.

Tempos solitários. O pai foi ausente, e o padrasto contribuiu na dimensão financeira, mas também era distante, assim como a irmã. Os tios e primos não moravam em sua cidade. A avó era "uma alemã muito brava, muito, muito rígida, mas a gente se dava [...] eu quebrava um pouquinho”. Sentimentos em relação a casa reforçam o isolamento e as cores cinzentas do "cubo" nessa etapa da vida: "A gente não tem uma relação boa com aquela casa. Porque [...] é gostoso, é gostoso pra você passear, é legal. Mas é longe. As pessoas não vão na sua casa $[\ldots]$ ”.

É, eu morei em sítio, então, brincadeiras de sítio mesmo: de subir em árvore, brincar na rua, comer fruta do pé [...] muito, muito sozinha, porque era filha única até seis anos, depois a minha irmã [...], seis anos de diferença é muito, você já não brinca mais. Mas brincava com os vizinhos dos sítios ao lado.

As lembranças felizes retomam as brincadeiras com os amigos, filhos dos caseiros dos sítios vizinhos e o cuidado com os bichos do sítio. Aprendeu com sua família e com a avó o amor pelos bichos: "Eu lembro uma vez que a gente achou um monte [...], porque o vizinho matou a gambá mãe, aí a gente ficou - eu e minha avó - cuidando dos gambazinhos. Mas morreram. Eram muito pequenininhos".

Dos primeiros tempos na escola... 
[...] não fui feliz em colégio [...] Eu não tive tempo de escola bom, foi sempre muito traumático. Eu mudei de escola, cada ano eu estava numa escola diferente. Por diversos problemas [...] Fui pra primeira escola, aí minha mãe separou, não teve como pagar, aí uma escola pública. Aí até seis anos eu mudei de escola, cada ano eu estava em uma diferente. Sempre muito chorona, sempre fui muito chorona. E muita dificuldade de ficar na sala, sempre [...] E, depois, eu fui pra uma escola jesuíta [...]

[...] eu fui muito esquecida na escola, então, eu lembro que eu indo pra casa, numa kombi [...] Que os meus pais separados, era dia do meu pai buscar, ele esquecia. Então, ninguém ia buscar. Então, eu lembro disso, d'eu indo pra casa na kombi. Que pra mim kombi era uma coisa imensa, porque era uma alemã muito brava, ela me botava no último banco e o dia já escuro e eu indo pra casa de kombi. Eu lembro dessa cena. Minha tia falou assim: 'Como é que você lembra? Você era muito pequenininha'. Eu não era muito pequenininha, eu era bebê. Mas eu me lembro. Que essa foi minha segunda escola, eu tinha dois anos.

Desses primeiros tempos, muito choro e muitas tentativas de fuga da escola. Com seis anos, uma nova mudança, agora para uma tradicional escola jesuíta da cidade onde morava e onde estudou da alfabetização ao $1^{\circ}$ ano do ensino médio. Sua mãe, formada em turismo, sempre trabalhou nessa área e, assim, saía muito, mas ela e o padrasto sempre se empenharam na escolarização de Simone, esforçaram-se para pagar um colégio particular que era referência na cidade:

Meu padrasto se esforçou muito pra pagar uma escola que não era nossa realidade financeira [...] Então, isso é muito [...] Não tinha, tinha pra pagar a escola, mas não tinha pra comprar calça de marca, mochila Company. Então, os meus amigos eram a filha do porteiro, a filha do professor, que eram as que tinham a mesma realidade que a minha.

Simone sentiu dificuldade de integração nessa nova escola: "Tinha vergonha da minha casa, não chamava ninguém pra ir lá em casa [...] Foi muito ruim. Passeio de escola nunca podia ir". 
Da prática pedagógica, poucas lembranças: "Acho que foi tão ruim que eu apaguei. Agora eu lembro que era tradicional. Isso eu lembro bem. Era método tradicional mesmo".

Eu lembro que eu estudava a tabuada na tabelinha; eu lembro do "ba, be, bi, bo, bu"; eu sei a cartilha que eu estudei [...] Eu lembro que eu tinha uma letra feia. Isso também era tortura. Minha mãe arrancava muita folha do caderno, ficava muito nervosa com a letra, porque a letra dela é muito bonita. Então, eu fiz muita caligrafia. Eu lembro que no colégio tinha o 'não devo falar durante a aula', escrever cem vezes. Mas eu lembro muito pouca coisa. Muito pouca coisa.

Da $5^{\mathrm{a}}$ à $8^{\mathrm{a}}$ série, continuou no mesmo colégio, mas em prédio antigo, centenário. Como não gostava de recreio e de ficar com o grupo, tornou-se amiga do inspetor e colaborava com ele na hora dos recreios carimbando as carteirinhas. Foi sempre querida pelos professores, mas "não era boa aluna, sempre passei raspando, eu sempre fiquei de recuperação. Não fui boa aluna. Eu não gostava de várias matérias e quando eu não gosto, eu crio um bloqueio. Eu não consigo, eu tenho dificuldade até pra ensinar matemática. Não gosto de matemática”.

Com 10, 11 anos, fez seu primeiro "ensaio" na docência:

Em frente ao colégio, tinha um orfanato, e eles tinham um projeto desde a $6^{a}$ série que a gente ia ajudar as crianças do orfanato a fazer o dever de casa, em horário contrário ao da escola. E todo mundo se empolgava no início do ano e não ficava. E eu sempre [...] e eu já estava há anos nesse projeto [...] Então eu sabia que ensinar era uma coisa que eu gostava.

Mas também recebeu influência da tia professora, que, nessa época, estudava pedagogia; assistiu a algumas aulas com a tia, fez leituras, foi, assim, se aproximando: "[...] Aí que queria fazer e eu resolvi que eu ia fazer pedagogia, que eu queria dar aula. Sempre gostei de criança, sempre gostei dessa coisa de ensinar". "Aí a minha tia sugeriu, por que que eu ia fazer até o $3^{\circ}$ ano de formação geral sofrendo - porque eu sofria com química, física - se eu podia fazer formação de professores? Aí ela sugeriu, mas só que a minha mãe não aceitou”. A mãe queria que Simone completasse o ensino médio no colégio em que estu- 
dava: "Porque era o sonho da vida dela. Porque quando você fica o ano inteiro, você ganha uma plaquinha e que não sei o quê. Aí o que que eu fiz? Eu fiz escondida a matrícula”. Simone continuou em seu colégio, mas fez a matrícula no Instituto de Educação de sua cidade. Um dia, sua mãe a viu quando descia as escadas e, a essa altura, já estava faltando às aulas de seu colégio:

Parei de frequentar o outro e ela pagando. E tive que voltar um ano, porque eu não pude começar o $2^{\circ}$ ano. Eu já tinha feito o $1^{\circ}$ ano no colégio, já estava no $2^{\circ}$ ano, mas tive que voltar o $1^{\circ}$ ano no Instituto de Educação. Aí eu comecei. Aí ela viu que não tinha mais jeito, que eu já estava sem frequentar há um mês o outro, aí fiquei.

O curso normal instaura uma nova etapa de vida e formação: "Eu fui feliz quando eu fui fazer formação de professores, quando eu fui pro Instituto de Educação [...] Uma escola pública. Ah, eu gostei. Aí eu me tornei uma das melhores alunas da sala. Aí foi aonde eu me encontrei assim”. Nessa escola, ela teve professores bons e fracos, muita greve, uma formação técnica e teórica.

Eu tinha aula de preparação de diário, aula de preparação de estêncil, aula de mural. E o mural era assim, cheio de técnicas. A gente tinha que ter um caderno de mural e o mural você botava o tema do projeto que você estava trabalhando, aí tinha umas setas assim [...] Então, eu lembro que o meu caderno era lindo e maravilhoso, mas eu nunca fiz um mural como aquele. Então, assim, a professora de didática da matemática [...], porque, eu não gostava de matemática, mas eu gostava da aula dela [...], ela trabalhava com jogos. Então os jogos que a gente fazia pra apresentar lá, eu guardei [...]

Lá tinha contação de histórias, que eu segui, que eu fiz depois intensivo no SESC, que eu quis dar continuidade [...] a sementinha foi plantada lá. Teve educação especial, que eu adoro [...] E algumas coisas foram aproveitadas, mas pouco, pouco. Alguns professores muito teóricos. Tanto que eu nem lembro. Eu lembro dos bons. Eu lembro desse do mural que era [...] essa que ensinava a trabalhar com flanelógrafo. Nunca vi um flanelógrafo na minha vida em escola nenhuma que eu fui trabalhar [...] Eu acho que de experiências de coisas que eu uso, que eu aprendi na escola normal, foram poucas. 
A realização do estágio significou um momento importante de formação, de contato com a realidade da escola e que contribuiu quando iniciou sua trajetória profissional. Simone começou a trabalhar com 14 anos no comércio; trabalhava e estudava durante o ano e nas férias de Natal. Assim que terminou o curso normal, fez concurso público para seu município e trabalhou durante quatro anos como professora da educação infantil, um tempo tranquilo, de identificação com a docência. Desde o início de sua trajetória, teve uma jornada dupla de trabalho: pela manhã na prefeitura, com educação infantil, e à tarde dois anos no $\mathrm{SESC}^{6}$ e dois anos com contrato no Estado, com turmas do ensino fundamental.

Não teve choque com a realidade em seus primeiros anos de trabalho: "[...] eu cheguei muito preparadinha, muito bem". Recebeu também a contribuição de sua melhor amiga, estagiou na sala dela, na escola normal, e, "então, ela me ajudou muito. Ela me deu muito material, me ensinou muita coisa". As primeiras turmas foram na zona rural, uma escola que ficava no meio da plantação de repolho e tinha duas salinhas e a cozinha. "Não tinha nem diretora, a diretora, ela dirigia quatro escolas [...] Era um ambiente muito gostoso, era muito bom". O acesso era difícil: "A gente andava a pé. A gente pegava carona até em carro de funerária, porque era muito longe. Mas era muito [...], o ambiente lá era muito gostoso, muito gostoso". Havia tempo de envolvimento integral com a docência:

Eu tinha um noivo, ele desenhava muito bem, a minha ex-sogra era professora do Instituto de Educação - didática da matemática - e a minha cunhada adorava preparar estêncil. Então, assim, final de semana eu envolvia a família inteira dele na preparação das minhas aulas [...] Ele desenhava, fazia meus cartazes. Se estava no computador, trazia coisas pra mim do computador. A minha sogra me ajudava construindo joguinhos matemáticos. Então assim $[\ldots]$ a gente passava o final de semana, era muito gostoso.

Nesse período, também deu continuidade aos estudos no curso de pedagogia, no qual prosseguiu sendo boa aluna: "Então já estava numa área que eu gostava. Eu gostava de tudo, já era a minha linguagem". "Uma faculdade muito boa e muito puxada [...] não era pagou passou, era puxada. E [...]

${ }^{6}$ Serviço Social do Comércio. 
é, eu acho que muitas coisas que eu uso ou que eu cheguei a usar foram da faculdade. Até de querer ler, de pesquisar, de ler mais, de bibliografia, foi da faculdade”. Mas também lembra de disciplinas que não sabe para que estão no curso.

Se, dentre outros aspectos, a faculdade contribuiu para aumentar seu desejo de ler, sua trajetória de leitura já vinha de longa data, pela especial presença de tios educadores:

Porque na minha casa, na minha família mesmo, a minha mãe, o meu padrasto, e a minha vó, não acontecia o processo de leitura. Esse meio de leitura eu não tinha. Ninguém lá lê nada. Agora, essa tia, desde [...] Até, assim, eu estava arrumando os livros, pra passar alguns pro quarto da Marina [...] e vendo a quantidade de livros que eu ganhei da minha tia, que ela foi me estimulando desde nova com esse movimento da leitura. E o meu tio, ele trabalha com política educacional. Ele trabalha como professor [...] então, ele incentivou assim, muito [...], uma reportagem ele botava: 'Olha que reportagem interessante'. Depois ele ficava me cobrando, 'Você leu? O que você achou?'.

Não, ela sempre me deu livro sobre as questôes que eu estava vivendo [...] Era sempre, o presente, um livro. E sempre que eu conquistava alguma coisa uma nota boa, um curso de inglês - eu ganhava um livro [...] O diário de Anne Frank, quando eu fiz 11 anos; De onde viemos, começou a despertar aquelas coisas de sexualidade. Assinatura da revista Capricho. Porque ela sabia que a minha mãe não ia responder nada das dúvidas [...] Minha mãe falava: 'Essa revista de empregada doméstica'. É, mas responde. E como ela estava morando no Rio [...] ela dava assinatura [...] É, aí, depois, quando eu fui ficando mais velha, Olga. Eu comecei a adorar ler biografias. Então Isadora Dantas, Olga, Iara [...] E assim e quando eu comecei a fazer formação de professores, aí foram livros que ela achava interessante $[\ldots]$

Um acontecimento biográfico de sua trajetória profissional traz novos rumos: o concurso que prestou para a Prefeitura foi anulado e Simone se viu de uma hora para outra sem trabalho. Distribuiu currículos em sua cidade e foi para a casa de seus tios no Rio, onde também começou a procurar trabalho e foi logo chamada para duas escolas particulares, nas quais passou um ano. Mudar de cidade foi uma felicidade: "Eu tô feliz agora". Fez concurso 
público para o município e, no ano seguinte, já estava trabalhando como professora efetiva da rede pública com uma matrícula, almoçava no ônibus, pois à tarde trabalhava em outra escola, fazendo "dobra"; em toda a sua trajetória, sempre teve duas turmas a cada ano letivo.

A escola pública em que foi trabalhar localiza-se em uma comunidade carente do Rio de Janeiro. A escola tem capacidade para seiscentos alunos, mas atende 1.200, não há recreio, porque não há espaço físico, as salas de aula são superlotadas: "A gente chega aqui com aquela sala que a gente não tem nem como entrar". Se em sua cidade natal teve boas condições materiais de trabalho, turmas menores e mais tranquilas, a experiência no município do Rio de Janeiro trouxe o choque com a realidade. A prática pedagógica é muito tradicional, houve a tentativa de que todos os professores utilizassem cartilhas no processo de alfabetização, e aí Simone precisou lutar contra uma escola inteira: "Minha tia falava assim: "Você tem que contra-argumentar". Quando eu estava chateada com a diretora, com alguma coisa. Porque eu tive durante esses dois anos que eu trabalhei com essa turma, a coordenadora queria cartilha. Aliás, nem era cartilha, era $O$ sonho de Talita [...] E eu não [...] e eu disse que eu não ia trabalhar com isso de jeito nenhum. Só que era eu contra a escola inteira que estava aceitando e adorando [...] Agora, quando chegava no outro ano, que eu peguei uma turma que tinha sido alfabetizada com $O$ sonho de Talita, e essa turma, eles não têm criatividade nenhuma. $\mathrm{Na}$ hora de formular uma frase, é "O Ivo viu a uva. A vaca está na lata".

Simone foi se deparando com uma realidade complexa, e a dificuldade de aprendizagem de alguns alunos começou a deixá-la inquieta:

Por que que você tem, na sala de aula, aquela meia dúzia que não aprende? Aí você tenta, você muda a sua rota, você procura, você puxa, e, muitas vezes, crianças interessadas. Não é porque estão desinteressadas, elas querem. Você quer. Aparentemente, a criança não tem nada que comprometa. Algumas com os pais ali também. E você não consegue.

Essas questōes a levaram a um curso de pós-graduação, e sua turma de 42 alunos de alfabetização foi campo da pesquisa de sua monografia.

E, então foi isso, eu quis fazer essa pós. Era um sonho [...] ajudou. Ajudou muita coisa. Ajudou, mais segurança pra mim, a você pesquisar mais, buscar 
mais, não se acomodar naquele [...], eu fiz tudo. Que mais que você pode fazer? Ajudou a contra-argumentar. Então, a me colocar na escola enquanto professora. A não aceitar tudo que é imposto pela política [...], ajudou, ajudou bastante. Agora quero fazer uma de educação especial.

Em sua prática pedagógica com essa turma, começou a perceber que a escola

vai perdendo os pais. Porque os pais começam a levar pra escola, porque é muito pequenininho, só que, aí, você começa a ver tanta reclamação, que esses pais começam a não ir mais. Você vê que deixou no começo da rua, mas não chegou até o portão da escola; aí começa a não ir mais em reunião.

Desenvolveu muitas tentativas para alcançar seus alunos, ficou dois anos com eles, tendo seu trabalho como campo de pesquisa, levando as discussões e aprendizagens do curso de pós-graduação:

Porque a pós era aos sábados. Então, eu chegava da pós, sentava pra fazer o meu planejamento. Então era legal, que as sugestões que apareciam - você conversando com colegas ou mesmo nas próprias aulas, eu colocava: 'Puxa, foi legal, vou colocar nessa semana'. Então, assim, o mais frustrante, o mais triste, é que essas crianças não atingiram nem 2004, nem 2005, e agora em 2006 também não. Elas continuam crianças com conceito 'i’. Elas vão pra progressão. Então, assim, o mais chato que eu achei que eu fosse encontrar a resposta, eu fosse encontrar a fórmula, a receita e não houve. Nem eu encontrei, e nem a minha colega que está com elas também não. Ela também chegou cheia de gás, tentou. 'Não, eu vou conseguir. Vou fazer, vou acontecer'. E está toda desestimulada. Então, assim, é muito difícil.

No cotidiano, procura pesquisar e experimentar, e a alfabetização se coloca como movimento. Quando houve uma imposição da escola no uso da cartilha, Simone subvertia e mandava como dever de casa:

Mas fazia outras coisas paralelas [...] Aí começa a criticar a cartilha junto com eles, mostrar pra eles que não é uma leitura gostosa. Então, assim, quando eu 
conto uma história na escola, na sala - e conto muitas - eu mostrava pra eles a diferença da leitura de um livro e quando eu ia ler a história da cartilha.

Trabalha com músicas, poesias de Cecília Meireles, literatura infantil e projetos pedagógicos:

É interessante, você pensa: 'O que que vai nortear o meu trabalho? O que eu vou fazer esse ano? Ah, esse ano [...]'. Nem penso no ano, eu penso no agora, e então entra música popular brasileira, pagode, $A$ arca de Nóe, de Vinícios de Moraes, Os saltimbancos. [...] Você vai buscando, vai experimentando, vai sugerindo, que dá certo pra colegas [...] Pode dar muito certo ou eu posso me sentir totalmente perdida. Me perder completamente. Então, assim, eu tenho que buscar uma outra coisa. Não, isso não deu.

Simone também trabalhou em turmas de progressão: "Os meus galalaus. Também gostava. Gostava, a amizade era boa, mas o atrito na sala não era”. Nos últimos anos, a experiência com educação especial, com crianças autistas e com paralisia cerebral trouxe uma aprendizagem significativa, construída no dia a dia com elas. Atualmente, com um $2^{\circ}$ ano, vive um momento de crise na docência: percebe que os professores estão sem apoio, só recebem críticas e cobranças quanto à produção dos alunos, são o tempo todo culpabilizados; por outro lado, falta participação dos pais na escola, há desinteresse dos próprios alunos e muita agressividade. Sente que seu "gás" está diminuindo: "Eu tinha um gás que eu não tenho mais, foi, assim, foi diminuindo". Mas o "cubo" se renova com o casamento, com a nova mudança de cidade, e a expectativa da chegada de Marina dá a ele novas cores, abrindo possibilidades de renovação:

Eu gosto muito de dar aula. Até escrevi pra uma amiga minha, falei - porque ela está na Secretaria - eu falei: 'Não, eu prefiro os meus melequentos e remelentos'. E frente ao questionamento do marido sobre a continuidade na docência, após o nascimento da filha: '[...] mas de jeito nenhum. Não, não abandono sala de aula. De jeito nenhum'. Aí porque eu estava muito desestimulada, muito desanimada, porque o final do ano estava chegando, e eu estava vendo que a turma não conquistou, não foi, não conquistou. E quando 
agora, eu estou de novo, voltou a esperança, porque eu vou mudar de escola. Então, assim, eu estou com muita esperança de melhor, mais apoio.

Assim como o porta-retrato em forma de cubo, com suas múltiplas faces - contemplando, por meio das fotos, a intensidade das relaçôes e dos significados das diferentes fases da vida -, o processo formador de Simone vem marcado pelo movimento, pela busca constante de construção do presente $e$ do futuro. Ao falar da importância do cubo como objeto significativo, a narradora sinaliza pessoas, acontecimentos, ciclos fundamentais de sua trajetória. O porta-retrato que vai do quarto da tia para o seu quarto acompanha a passagem de sua vida por diferentes tempos e espaços: imagens da infância, do namorado, dos/as alunos/as, dos amigos de escola, da melhor amiga. Atualmente, voltou a fotos da infância que já estiveram no cubo, em um resgate de seu passado e de prospecção sobre a chegada de sua filha.

A infância foi retratada como tempo de solidão e isolamento. Da vida no sítio, ficaram as boas lembranças das brincadeiras com os vizinhos e do contato com os bichos. Mas o cotidiano e a escola representam um tempo de recolhimento. A separação dos pais, quando ainda era bem pequena, o fato de ir morar com a avó, a relação de distância da família e o isolamento do sítio trazem para o cubo cores cinzentas. Durante a educação infantil, muitas mudanças de escola, choro e tentativas de fuga. Da alfabetização ao $1^{\circ}$ ano do ensino médio, Simone estudou numa tradicional escola de sua cidade, na qual teve muita dificuldade de integração, "não era boa aluna, passava raspando".

O trabalho está presente em sua trajetória desde muito cedo: com 14 anos começa no comércio, conciliando estudo e trabalho. Em sua história de vida, formação e leitura, os tios, apesar de não morarem na mesma cidade, assumem um lugar importante, trazendo o diálogo, a proximidade, os livros e uma visão crítica sobre a vida. No contato com a tia professora, surge o desejo de fazer o curso normal e pedagogia. A decisão de abandonar sua escola e de ingressar no Instituto de Educação, contra a vontade de sua mãe, trouxe uma ruptura importante, instaurou um novo ciclo de estudo, agora em um tempo de encontro pessoal e de felicidade. 
O início da trajetória profissional aconteceu em sua cidade natal, em um movimento tranquilo, de aprofundamento dos estudos acadêmicos com a graduação e identificação com a docência da educação infantil. Mas foi a anulação do concurso que prestou para a Prefeitura que trouxe um segundo movimento de ruptura: a mudança para a casa dos tios, na cidade do Rio de Janeiro, e o início de uma nova etapa profissional, inicialmente como professora de duas escolas particulares e, logo depois, como professora do município. Aqui, vivenciou o encontro com uma nova realidade educativa: turmas cheias, dificuldades de aprendizagem dos alunos.

Nesse contexto, Simone luta pela continuidade de uma prática docente instituinte, a alfabetização como experimentação e construção vivida de forma especial com cada turma. Vai, assim, nutrindo um intenso processo formador que se dá no confronto com os desafios da docência: a aprendizagem do contra-argumentar, a realização da pós-graduação, a pesquisa e o constante investimento no processo de ensino-aprendizagem junto aos alunos. Mas experimenta também um tempo de crise que vem com um sentimento de abandono, por causa das dificuldades estruturais no desenvolvimento do trabalho.

O casamento, a mudança de cidade e a espera pelo nascimento da filha trazem, entretanto, uma renovação da esperança e de expectativas de futuro sobre a vida e a profissão.

Os contextos geográficos têm, na trajetória de Simone, a importância de marcos, de referências para os ciclos da vida. Até os 23 anos, vive em sua cidade natal; ali, desfrutava tempos de recolhimento, mas também de felicidade, tendo como cenário a cidade pequena, serrana e fria. A mudança para o Rio de Janeiro consagra sua afirmação pessoal e profissional e traz um intenso processo formador. Ela se identifica com a cidade. Com o casamento, vivencia uma nova mudança de cidade, instaurando um ciclo de intensa afetividade e esperança, envolvendo agora o marido e a filha.

A narrativa de Simone aponta a confluência de fatores que caracterizam sua formação. A opção pela docência constitui um acontecimento central, muda sua relação com a escola e com o próprio processo formativo. A partir daí, a formação acadêmica por meio do curso normal, da graduação em pedagogia, da pós-graduação, articulada aos movimentos inquietantes da prática educativa, indica o sentido de seus projetos de futuro. Formação 
acadêmica e prática docente aliam-se a uma busca constante de construção do conhecimento que se dá pela pesquisa e pela experimentação.

\section{Histórias de professoras: tessituras da intriga}

Percorremos um longo caminho. Inicialmente, recontamos a história, entrelaçando a voz das professoras e da investigadora; depois, trouxemos elementos de análise sobre os sentidos da trajetória da vida e da formação, que, no último encontro, foram partilhados com cada uma delas. As narrativas nos proporcionam um mergulho, uma viagem em diferentes universos sociais, históricos e culturais, em uma confluência de pessoas, lugares, acontecimentos, sentimentos - experiências que mediatizam o coletivo a mais pessoal e o pessoal às tramas coletivas.

As vozes das professoras, suas histórias, recontadas na narrativa oral, reconstruídas em texto, compõem uma "tessitura de intrigas", na acepção de Ricoeur (1994). Os acontecimentos e experiências não se sucedem de forma aleatória, mas se articulam em uma trama de sentidos que se abrem a polifônicas possibilidades interpretativas para o próprio narrador, para quem reconstrói, por escrito, a história narrada e para quem lê.

Então, encontramos nas narrativas a tríplice mimese (Ricoeur, 1994), pois passam pela ação humana, por sua recriação narrativa e pela reconstrução que se dá na leitura. A compreensão da ação nos coloca frente ao universo social, cultural e histórico em que se encontram as intrigas, em um diálogo entre Brasil e Portugal, zonas urbanas e rurais, dando visibilidade a diferentes formas de ensinar e aprender, percorrendo, em lampejos, um espectro temporal que vai do início do século XX, com as histórias das avós, aos dias atuais. Em cada intriga, explicação e compreensão se entrelaçam, pois dialeticamente somos levados à análise e à síntese, ao detalhe e à composição de uma ampla configuração, à "sintese do heterogêneo" (Ricoeur, 1994), um simbolismo presente na ação que precisa ser desvendado, que permite a inteligibilidade das dinâmicas particulares.

A tessitura apresenta uma dimensão cronológica pela referência a acontecimentos que se passam em diferentes fases da vida, na infância, na adolescência/juventude e na vida adulta, mas abre-se de forma não linear quando focalizamos os acontecimentos biográficos centrais da trajetória de vida e 
formação das narradoras, num movimento "configurante dos incidentes da história” (Ricoeur, 1994).

$\mathrm{Na}$ intensidade do "encontro de horizontes" (Azzan, 1993, pp. 18, 22), buscamos o diálogo de configurações e sentidos. É o leitor que deve recriar as referências do próprio texto. Logo, cada história é um convite a novas histórias, interpretações e aprendizagens. Aprendemos quando ouvimos o outro. As histórias de vida de professoras nos ensinam, elas falam por si, como "metáforas vivas", produzem um "excesso" de significados (Ricouer, 1996). 


\section{Capítulo 7 \\ Trajetórias em diálogo}

No capítulo anterior, tomamos a história de vida das professoras em uma análise vertical, ou seja, em um olhar dirigido à trajetória de cada uma, como tessitura da intriga, como histórias que podem ser seguidas (Ricouer, 1994) e que, por si, ensinam, dizem de sentidos do processo formador na articulação entre histórias familiares, contextos sócio-históricos, experiências do processo de escolarização formal e configurações da prática educativa. No presente texto, retomamos as histórias em uma análise horizontal, buscando o diálogo entre elas na especificidade das categorias centrais da presente investigação e de seus desdobramentos em eixos temáticos; assim, cada um desses eixos será observado nas diferentes formas como aparece na trajetória das 12 professoras.

Nesse movimento, reafirmamos a centralidade do diálogo entre uma diversidade de contextos históricos e geográficos que envolvem Brasil e Portugal, bem como de diferentes formas de produção da vida, da docência, da formação, dando visibilidade a sentidos comuns e a diferenças singularidades. Deparamo-nos com alguns discursos e práticas que se entrelaçam - o eu e o outro se encontram, apesar das diferenças regionais e históricas, o pensamento e a práxis educativa rompem fronteiras e configuram-se como imaginário coletivo, como "comunidade imaginada" (Nóvoa, 1995a, 2000), permitindo perceber preocupações, questionamentos, reflexões e encaminhamentos que se unem. Por outro lado, somos também confrontados com a beleza da singularidade, do indício, do vestígio que se coloca na especificidade do contexto, na tessitura de uma trajetória e, desse modo, um mesmo acontecimento gera diferentes sentidos e leituras. 
Buscamos, dessa forma, o exercício da mediação entre contextos e singularidades. Observamos que a construção do conhecimento sobre o mundo, a vida e a formação se afirma no encontro e no diálogo com o outro e nas possibilidades que esse encontro gera quanto ao ensinar, ao aprender e, especialmente, no transformar de si mesmo, do outro e do mundo, em partilha. A narrativa das histórias das professoras que fazem parte da presente investigação aproxima-as como sujeitos históricos que, no dia a dia, produzem educação e formação e, ao ler suas histórias e colocá-las em diálogo, encontramos faíscas instituintes que potencialmente se fortalecem.

\section{Diálogos}

\section{Diferentes configurações da trajetória de vida e formação}

Quando observamos a trajetória de vida e formação de cada professora, encontramos movimentos próprios que fazem o trançado de uma "colcha de retalhos", em que cada "retalho", como fragmento de memória, apresenta diferentes cores, intensidades e recortes. As possibilidades de compreensão e a leitura de sentidos vêm pela conjugação desses fragmentos, na "tessitura da intriga" que vai contando diferentes histórias. No olhar para as 12 narrativas, encontramos movimentos comuns desse trançado? Quais seriam eles? Por outro lado, o que singulariza as trajetórias das professoras participantes da presente investigação?

A trajetória, como construção humana, pessoal-coletiva, vai sendo tecida em um desenrolar de vivências e experiências, ${ }^{1}$ de "acontecimentos da biografia" - como processo cotidianamente tecido entre planejamentos, desejos e possibilidades de realização, marcando uma sequência e de "acontecimentos biográficos" que vêm como acidentes, como marcos, o não esperado que muda o rumo, instaurando novas etapas. Segundo Leclerc-Olive (apud Fond-Harmant, 1995), os acontecimentos se dão pela "ação do sujeito", por "acidentes" em que é vítima e por "encontros". O autor também cita os "acontecimentos no mundo", pela influência do contexto sócio-histórico. Ainda segundo ele, os "acontecimentos na biografia” assumem importância diferenciada, enquanto os "acontecimentos biográficos" podem indicar uma

\footnotetext{
1 Tomamos como referência a concepção benjaminiana, analisada no capítulo 4 .
} 
reestruturação existencial, a abertura de novos ciclos (Leclerc-Olive apud Fond-Harmant, 1995, pp. 14-5). Na análise da trajetória das professoras, observamos esse movimento em que o desenrolar cotidiano é interrompido por incidentes, abrindo sempre novos e inesperados caminhos de formação.

$\mathrm{Na}$ análise de conteúdo, a delimitação das diferentes etapas e fases da trajetória de vida de cada uma das 12 professoras não consistiu uma intenção metodológica prévia, mas veio como uma construção que saltou da própria análise, apresentando-se como um dos caminhos de leitura possíveis. Como referência de análise, tomamos os grandes momentos da vida: a infância, a adolescência/juventude e a vida adulta, buscando, entretanto, uma delimitação definida, não por faixas etárias previamente dadas, mas pela dinâmica de cada uma das trajetórias. Nessa análise, observamos que as rupturas vão se dando, nomeadamente, por acontecimentos biográficos que delineiam a configuração desses grandes momentos da vida, articulando etapas e fases. O sentido de cada uma delas vem com a marca de uma composição muito singular de elementos que sintetizam vivências/experiências/sentimentos de diferentes dimensões da vida pessoal, acadêmica e profissional, em uma tessitura compósita - em alguns casos, mostrando a predominância de uma dessas dimensóes; em outros, afirmando justamente o contraponto entre experiências que se opõem e geram tensão.

Nas histórias de vida analisadas, encontramos um traço comum na passagem da infância para a adolescência: a centralidade da mudança da escola primária para o ciclo posterior de escolarização. Vemos, então, por um lado, a importância da escola no abrir de uma nova etapa de vida e formação. Por outro, essa experiência assume singularidades: na trajetória de Ana, foi um momento de grande ruptura e sofrimento, pela mudança de sua aldeia para a cidade e pelo afastamento da família, gerando dificuldades no processo de aprendizagem; para Teresa, Isabel e Clara, representou uma etapa que carrega o sentimento de libertação das opressões da escola primária, instaurando um tempo de maior tranquilidade e prazer. Se as narrativas das professoras brasileiras contam diferentes experiências, focalizando, porém, a importância da escola, a trajetória de Hélida apresenta-nos uma versão singular: é a experiência de vida com o grupo de colegas da turma do "mau-mau", que traz

2 "[...] eu fiz um grupo de amigos que é um grupo de amigos diferente, eles eram adolescentes diferentes dos adolescentes mais moleques, eram intelectuais. Nessa época, eu li Hamlet, eu li Macbeth, eu fui a concerto na Sala Cecília Meireles, eu só fazia coisa de intelectual, porque 
intensos momentos de aprendizagem e marca a passagem de ciclo - nas palavras da professora "uma época transformadora", em que a praça e o encontro informal roubam a cena da escola.

$\mathrm{Na}$ passagem da juventude para a vida adulta, encontramos, para professoras portuguesas e brasileiras, a centralidade de uma nova etapa de vida familiar, o início e o desenrolar da trajetória profissional, movimentos que indicam um processo de autonomização pessoal, de afirmação de um novo momento de vida, que se desdobra, para cada uma, de diferentes formas. O casamento ${ }^{3}$ e o nascimento dos filhos vêm, de igual forma, como elementos fundamentais e exigem a articulação, muitas vezes difícil, entre os desafios da docência e as demandas da vida pessoal. Observamos em 11 das 12 professoras a realização da licenciaturalgraduação como um acontecimento da vida adulta; apenas Clara tem na licenciatura a formação inicial, para todas as outras - tanto portuguesas como brasileiras - o curso do magistério primário/curso normal foi a primeira instância de formação docente. Nesse momento, também se colocam cursos de formação continua e a partilha no ambiente escolar, bem como a troca com colegas, como elementos fundamentais de formação.

Olhando em perspectiva, e colocando cada uma das trajetórias lado a lado, somos confrontados com a beleza da vida como movimento. $\mathrm{Na}$ infância, juventude e vida adulta, são muitas as etapas e fases que se desdobram, marcando uma dinâmica própria que articula vivências e experiências, acontecimentos da biografia e acontecimentos biográficos, indicando também a conjugação de uma multiplicidade de dimensões, espaços e tempos formadores.

Dialogando com as contribuições de Dubar (1996), analisadas no capítulo 4, observamos, na trajetória das professoras, que, na infância, a família e a escola se colocam como espaços-tempos da primeira socialização, de mobilização de aprendizagens e de um processo formador que gera as primeiras imagens sobre a vida e a docência. A socialização secundária se dá, segundo o referido autor, na adolescência e na vida adulta, quando as relações se ampliam em uma multiplicidade de grupos, espaços e instituições, e, nesse

eles eram intelectuais, esses amigos. Além de jogarem mau-mau, não é? Aí era a parte nada intelectual, a gente jogava muito mau-mau. E, assim, era um grupo que gostava de rock, mas rock progressivo era "Yes, The People, Pink Floyd", era o que a gente ouvia fora, um deles era compositor de ópera" (Hélida).

3 No momento da pesquisa, a professora Clara era solteira e vivia o início da trajetória profissional. 
momento, as experiências profissionais assumem grande centralidade. Cada um desses momentos da vida traz as marcas de um processo plural que liga o sujeito a diferentes contextos, permeados de contradiçôes, tensões, contrapontos e dualidades. Assim, encontramos indícios da inteligibilidade do processo formador quando conseguimos apreender sentidos que se colocam para o sujeito na tessitura desses movimentos, na tensão em que se encontra imersa cada uma das experiências, etapas e fases da vida.

Figura 3: Socialização primária e secundária

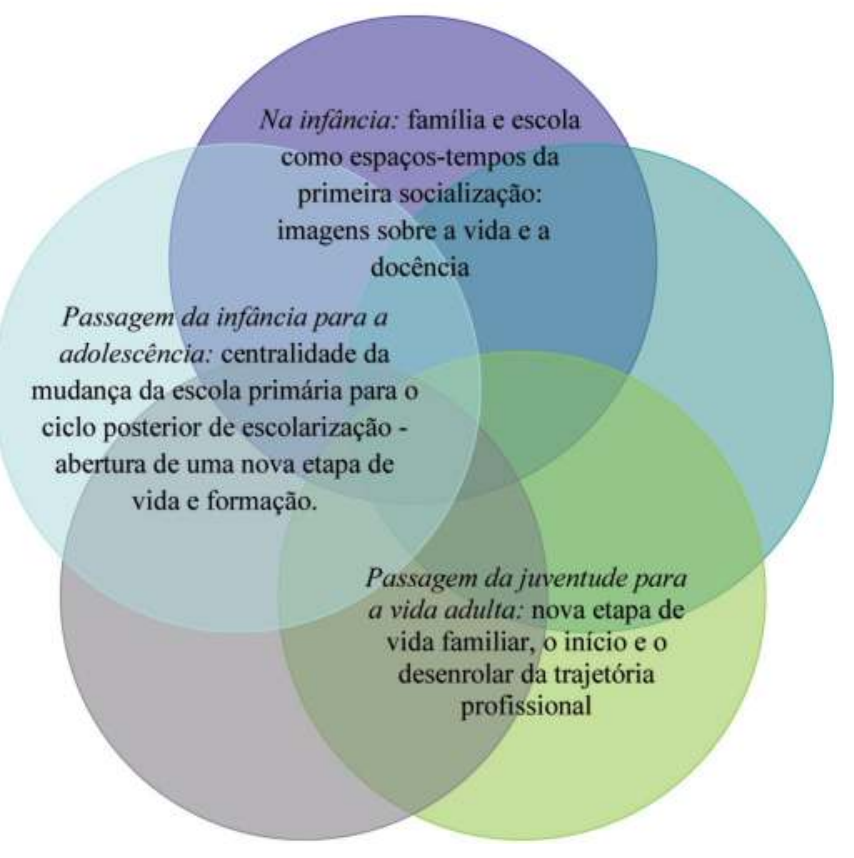

Formas de ser e de estar: o processo identitário

Apesar de não haver nenhum tópico do roteiro das entrevistas biográficas direcionado para a forma de ser e estar, ao narrar suas histórias de vida, ao revisitar e reconstruir as experiências significativas de formação, as professoras foram expressando "imagens" de si, formas de ver o mundo, mudanças e construçôes tecidas ao longo da vida. Foram recorrentes reflexôes impreg- 
nadas na própria narrativa e que dizem da forma como se veem na vida como pessoas e professoras.

Retornando ao tema do processo identitário, ${ }^{4}$ buscamos, na concepção dialética, compreender a identidade como processo permanente de construção, aberto à mudança. A identidade como "imagem de si, para si e para os outros" (Pollak, 1992), tendo, assim, uma dimensão pessoal - organização relativamente durável relacionada à forma como o sujeito vê a si próprio, tendo como referência sua biografia; uma dimensão social que se relaciona aos papéis assumidos em diferentes contextos, bem como à forma como esse sujeito é visto pelas pessoas com quem interage; e uma dimensão situada em contexto, que, em determinada situação, articula as duas anteriores, ou seja, a imagem pessoal e a social.

Por meio de fragmentos e lampejos, traremos as falas das professoras nesse movimento de dizer de si, de sua autoimagem:

Pois é assim, por isso eu vivo com muita intensidade estas coisas, talvez porque as viva com amor, com paixão [...] Sou uma pessoa muito emotiva, vivo intensamente tudo, me apego às coisas, às pessoas, aos momentos com muita força, com muita intensidade (Ana).

[...] É para eu fazer? Eu sou capaz, por que não? Mas isto tudo, também a infância das pessoas conta, as vivências das pessoas contam (Teresa).

Portanto, foi um esforço mesmo que eu tive que fazer e penso que, todo esse esforço - que começou a ser feito de pequenina - acho que deve ter ajudado e serviu de base para que tudo o que eu faça, mesmo que seja com muito esforço, é com muita vontade, muito grande de o fazer, uma vontade muito firme, agarro-me às coisas sempre com muita força. Quando penso em fazer uma coisa, eu tento levá-la até o fim (Carolina).

[...] Sou muito positiva e ainda bem que sou [...] Eu sou positiva, eu tenho um feitio de, para frente, pronto, é assim. E vale muito eu ter, eu ser assim uma pessoa com energia porque senão [...] (Bela).

4 Tema discutido no item "Formação, aprendizagem experiencial e processos identitários", do capítulo 4 . 
Eu fui sempre uma pessoa que vejo com as mãos, eu sou portuguesa! Eu gosto de apalpar, eu gosto de sentir, eu sou uma pessoa que gosto de sentir o outro [...] Também não sou pessoa de conflitos [...] tento sempre amenizar e dar um bocadinho de cor às coisas, para não serem assim tão cinzentas e, às vezes, são graves e a pessoa, se lhe puser um bocadinho de cor, tornam-se menos graves e pronto e lá fui fazendo a vida assim, aos poucos (Isabel).

Eu gosto de aventuras e vou me arriscar sempre, eu já me conheço nisso, não gosto de rotina, sou curiosa, portanto, eu acho que são dois ingredientes para um professor: ser curioso e estar sempre aberto a novidade, portanto, gostar e ser curioso e abrir sempre portas [...] Eu sou muito exigente comigo própria, eu gosto de fazer as coisas benfeitas, muito bem estruturadas, planeadas [...] (Clara).

Eu sempre me disse muito tradicional, mas não pareço. Eu sei que eu tenho esse jeito meio hippie, meio louca. Eu já fui [...] metaleira [...] Eu sempre fui muito selerepe, muito intrometida, muito [...] Gostava de participar de tudo que era clube, tudo que tinha para se participar eu gostava de participar (Hélida).

[...] Sempre fui muito quieta, muito, um pouco boba [...] Me considero uma pessoa, assim, aberta, assim, de conversar, de falar, se precisar de mim, eu gosto de ajudar. Mas poucos são aqueles mais próximos de você abrir seu coração, mas eu gosto, assim, eu gosto de fazer amizade, eu gosto também de ser útil à pessoa, de ouvir [...] (Rute).

Eu sou uma pessoa de boa paz, eu acho que eu tenho um temperamento tranquilo [...] Olha como eu sou muito 'caxias' [...] Não sei se eu sou também um produto da minha época, da minha família, da minha época, da educação que eu tive na escola [...] (Eloisa).

É, eu sou muito solícita. Eu me presto muito, eu mostro (Simone).

[...] eu sou, sou assim, eu gosto muito de fazer amizade, de cativar as pessoas [...] Mas a gente tem que passar por isso tudo se quiser vencer, senão você 
não vence, não adianta, se não tiver o sacrifício, as pedras no caminho, você não consegue chegar a lugar nenhum (Marta).

Eu sou muito autêntica nas minhas coisas [...] Mas eu sempre fui calma, tranquila (Rosangela).

O movimento e o fluxo narrativo de cada professora trazem indícios da forma de ser e de estar, umas mais abertas, outras mais contidas. Narrativas que vão e voltam de forma livre; outras compassadas e marcadas por uma reflexão prévia e medida pela professora. Ao falar de sua trajetória, Ana, por exemplo, se confronta e analisa criticamente sua autoimagem: o apego, a afetividade, a intensidade tomam sua vida e essas marcas aparecem na narrativa. $\mathrm{O}$ primeiro encontro trouxe uma profusão narrativa que gerou autorreflexão e censura, sentiu que falou muito, expôs a si mesma e se sentiu incomodada; todavia, nessa mesma reflexão, afirmou perceber que não há como recontar suas experiências de forma isenta e neutra, pois a intensidade de sua forma de ser toma por inteiro o próprio movimento narrativo.

A reconstrução narrativa de si traz a possibilidade de rever, como num filme, imagens que ao longo da vida se transformam, entretecidas pelos contextos, pelas experiências pessoais-coletivas. Rute, quando fala da adolescência e do ginásio, apresenta-nos uma menina quieta e tímida que sofre com as implicâncias dos colegas. Entretanto, os desafios de falar em público nas atividades da igreja, as apresentações de trabalho na escola normal, foram constituindo aprendizagens experienciais significativas que, "a pouco e pouco", apresentam-nos uma engajada representante de turma, ativa e desenvolta professora e estudante de graduação. Na história de Rosangela, encontramos uma menina que veio da roça para vila, inicialmente aceitando e convivendo com o preconceito e a discriminação - a mãe a ensinava a abaixar a cabeça, mas seu sucesso como aluna, o fato de a mãe conseguir trabalho como merendeira da escola, levam à afirmação da autoestima, da força, do sentir-se capaz, cidadã, movimentos que foram tecendo uma professora que luta pela igualdade de direitos e milita na causa do movimento negro.

As características e definições pessoais indicam sentidos que se complementam, mas também se afirmam pelo contraste, em uma composição que singulariza cada professora. Ao longo dos quatro encontros, Hélida, em diferentes momentos, buscou definições de si. Tomando essas definiçôes em seu conjunto, 
observamos uma contraposição de elementos que, na tensão, compõem uma possibilidade de leitura singular: ser tradicional, ritualista e meio hippie, louca, metaleira, serelepe. $\mathrm{Na}$ trajetória de Bela, a contraposição se deu em uma intensa luta pela afirmação de si mesma contra a imagem social vigente sobre o comportamento das "meninas". Ela gosta do que é emotivo, é impulsiva: "Tenho, muitas vezes, o coração ao pé da boca"; tem grande energia, vivacidade, sempre se expõe sem inibição, uma forma de ser que foi severamente cerceada, mas que o tempo todo procurou manter e reafirmar. Foi assim que as brincadeiras felizes com os amigos, no contexto da vizinhança, colocaram-se como contraponto à rigidez da escola primária; a prática do desporto e do basquetebol se contrapôs à repressão do ginásio e do Liceu e sua força e energia se contrapóem, no presente, à tristeza gerada pela perda de pessoas queridas. Bela não desiste, enfrenta, passa por grande dor e sofrimento, mas busca sempre a superação. Em sua narrativa, observamos que, se a docência de $1^{\circ}$ ciclo não veio, inicialmente, como uma opção pessoal, mas muito direcionada pela família, ao longo da carreira foi percebendo como sua forma de ser identifica-se com a docência, onde encontra espaço para manter a vivacidade de sua infância, a energia e o lado brincalhão.

Ao ouvir as histórias, somos apresentados a pessoas e vamos conhecendo e compondo imagens sociais a respeito do perfil traçado por cada uma a respeito de si. Imagens que se articulam à narrativa das práticas e experiências como professoras, ou seja, o olhar para a complexidade da história de vida, na amplitude da infância, juventude e vida adulta e na diversidade das dimensões pessoais, acadêmicas e profissionais, abre caminhos para perceber vestígios profundos da imbricação indissociável entre o pessoal e o profissional. Carolina identifica na infância a experiência do trabalho junto à família como uma aprendizagem que se revela em sua forma de ser: o agarrar-se às coisas com força, o não desistir. $\mathrm{Na}$ narrativa de sua história, retoma e reatualiza, de diversas formas, esse movimento. $\mathrm{O}$ trabalho com os alunos é intenso, exige além do tempo na escola, horas de trabalho em casa, a elaboração de fichas, as pesquisas, e tudo isso junto com as demandas da vida como mãe e esposa; ela enfrenta com força e entusiasmo, não desiste e ainda continua depois da aposentadoria. Da mesma forma, olhando a trajetória de Clara, observamos que as características de ser exigente, fazer tudo muito benfeito, a curiosidade e a abertura se manifestam na vida e em sua forma de ser e de se relacionar com a docência e com os alunos. Nas histórias de Eloisa, Marta e Rosangela, 
o rigor, a aprendizagem da disciplina, mas também a afetividade na família e na escola, as acompanham e se manifestam na docência.

O convite para contar sua história trouxe para essas professoras a possibilidade de reconstrução da narrativa de si, na tensão entre a reatualização de imagens do passado e dos projetos de futuro. A narrativa da história de vida indica, assim, o sentido ontológico de construção de si em um movimento de formação que, como processo vital de conhecimento, produz sempre novas possibilidades de leitura/imagem do sujeito a respeito de si próprio, bem como de leituras sociais e situadas nos diversos contextos em que vive e interage.

\section{Memórias polifônicas da vida}

Voltando à proposição paradigmática de Ada Abraham, "O professor é uma pessoa" (Nóvoa, 1992a, p. 15), e ao item anterior, notamos que as narrativas apresentadas falam de mulheres que são professoras e levam para a sala de aula o que, naquele momento situado, estão sendo, em uma síntese da leitura que têm de si, do papel de professoras, da forma como são vistas pelos outros e das demandas do contexto. Uma tessitura de aprendizagens transforma o modo como vêm sendo pessoas e profissionais, produzindo, no conjunto, formação e mobilizando sempre novas imagens de si. Na complexidade desse processo, questionamos: qual o papel das experiências pessoais na formação das mulheres-professoras que fazem parte desta investigação? Continuando o diálogo, propomos, então, olhar, em cada uma das trajetórias, sentidos atribuidos às experiências pessoais, familiares e contextuais, bem como o lugar de pessoas significativas que, não sendo professores e fora do contexto escolar, assumem a centralidade de educadores.

O estudo das histórias de vida e o olhar geral para o "quadro de análise comparativa - pontos centrais das biografias educativas" - ${ }^{5}$ permitem que percebamos a centralidade de acontecimentos pessoais na formação das professoras. Chamamos de dimensão pessoal aquela que se passa na família,

\footnotetext{
5 Quadro de análise no qual colocamos, em uma tabela de seis colunas, os pontos centrais das biografias educativas das professoras, extraídos do quadro temático-cronológico de cada uma delas. Fizemos uma tabela para as professoras portuguesas e outra para as brasileiras, visando favorecer uma leitura de conjunto. Relemos e marcamos com diferentes cores os acontecimentos ligados às dimensôes pessoais, acadêmicas e profissionais.
} 
na vizinhança e nos contextos sociais mais amplos, em que a aprendizagem se apresenta pela natureza intrínseca das relações do ser humano com as pessoas, com o mundo e com a natureza, constituindo ambientes informais de aprendizagem. Observamos, assim, que as imagens sobre a docência vão sendo construídas desde muito cedo, que a formação das professoras participantes da pesquisa não se "inicia”" com o Curso do Magistério Primário/Curso Normal ou com a licenciaturalgraduação, mas é um processo que se coloca na vida, antes mesmo da entrada formal na escola. Nas relaçôes familiares, sociais e históricas, vamos nos constituindo, e esses fios se manifestam em nossa forma de ser como pessoas e, posteriormente, professoras.

É na narrativa da infância que encontramos o maior peso da formação pessoal e depois, em escala decrescente, na juventude e na vida adulta. Para as professoras participantes, falar da vida como tempo-espaço de formação pessoal e profissional significa colocar peso sobre referências fundacionais que se afirmam antes mesmo da entrada na escola e se reatualizam e se transformam ao longo da vida. São referências que falam de aprendizagens junto aos pais ou ao núcleo familiar mais próximo.

Os pais das professoras portuguesas participantes da pesquisa nasceram na primeira metade do século XX e viveram o contexto da aldeia, apresentando uma escolarização formal que vai, no máximo, até a $4^{\underline{a}}$ classe, sendo que alguns não tiveram acesso à escola. Nessa geração, algumas histórias se referem a grandes dificuldades financeiras, emigraçōes para a África, a Alemanha e o Brasil - portugueses que foram buscar melhores oportunidades de vida. Mas também falam sobre a dificuldade de acesso à escola, especialmente para a continuidade dos estudos após o término da $4^{\mathrm{a}}$ classe, e sobre a ênfase dada ao trabalho, e não ao estudo, e à imagem social das mulheres, que, mesmo nas famílias que tinham condições, não eram incentivadas a estudar.

Olha os meus pais foram pessoas que sofreram um bocado [...] A minha mãe foi uma miúda que, enfim, foi sacrificada no trabalho, embora os pais dela pudessem até ter aproveitado e ter posto os filhos a estudar, mas, naquele tempo: 'Ah, vão estudar?', 'Não, é trabalhar'. E trabalhar em casa e trabalhar no campo e etc., e a minha mãe era muito inteligente e viveu um bocado triste com essa situação. $\mathrm{O}$ meu pai foi uma pessoa que teve muita necessidade, porque o meu avô saiu, foi para o Brasil e andou por lá muitos anos perdido e minha avó, coitada, que tinha cinco filhos [...] era uma família pobre que nunca lhe faltou pão, 
porque ela era padeira. A mãe do meu pai, mas passou muita necessidade, muita, e ele teve que ser o enxerto de família, aos oito anos de idade, não é? (Teresa)

O contexto de vida dos pais das professoras brasileiras apresenta certa diversidade, inclusive pelo fato de haver maior variação etária entre elas. Os pais de quatro professoras também nasceram na primeira metade do século $\mathrm{XX}$ e os de outras duas, no início da segunda metade. Os contextos de vida variam entre cenários urbanos e rurais. Quanto à escolarização, os pais de três professoras têm nível médio e os de outras três, o primário, registrando a formação de uma das mães em curso superior. No caso das famílias das seis professoras, foram justamente os mais jovens que tiveram acesso a mais tempo de formação escolar, fato que se relaciona à progressiva ampliação e ao atendimento da demanda por escolarização no Brasil. As histórias dos pais também falam de contextos difíceis do ponto de vista econômico e de interdição dos projetos de escolarização das mulheres.

Minha mãe fez até, na época, o curso ginasial, à noite, mas com 14 anos minha avó fez com que ela parasse de estudar para aprender um ofício. Também, não é? Isso há quantos anos atrás? Sessenta anos atrás. Já a minha mãe pensava de outra forma $[\ldots]$ (Eloisa).

Mas são esses pais portugueses e brasileiros, que tiveram grande dificuldade de acesso à escola e de continuidade dos estudos, que sempre incentivaram de forma decisiva o processo de escolarização de suas filhas, muitos deles interferindo também na escolha da docência como profissão. É preciso, entretanto, destacar o papel exercido, especialmente pelas "mães", na materialização concreta do incentivo, no apoio e no direcionamento:

Depois, eu vim para a cidade, minha mãe veio trabalhar com a expectativa de dar-me a mim aquilo que ela nunca tinha conseguido - a escolaridade [...] Com esforço, com um bocado de esforço, porque tinha que ser um esforço da minha parte, a minha mãe ajudava-me, pronto, ajudava-me naquilo que era possível, agora, em termos de apoio escolar nunca me pôde ajudar (Carolina).

A família, por parte de mãe, todos imigrantes portugueses. Papai nascido no interior do estado do Rio de Janeiro, filho de português também com uma 
brasileira. Meu pai era lanterneiro, minha mãe era do lar, é, para colocar um pouco mais de dinheiro em casa, ela costurava muito para fora e nem por isso deixava de nos dar atenção. Uma memória que eu tenho é a minha mãe sentada na máquina de costura, com o livro do lado tomando ponto (Eloisa).

Além do incentivo à escolarização, é também do ambiente familiar que vêm os exemplos de vida. Ana se refere aos valores, à afetividade, à aprendizagem da luta e do trabalho e ao reconhecimento do forte investimento em sua formação, como marcos fundamentais que levou para a vida e, nesse sentido, avalia seu empenho e grande esforço na construção de sua formação e profissão como resposta à dedicação e às expectativas dos pais. Na trajetória de Teresa, encontramos a centralidade da aprendizagem do valor do trabalho. Desde muito pequenina, trabalhou sob forte rigor do pai. Quando adulta, em momentos difíceis, teve a oportunidade de reconhecer a importância daquela aprendizagem. Já Carolina traz da infância a beleza das partilhas com a mãe, a avó e os tios: a afetividade, as histórias à beira da lareira, as experiências de trabalho junto com a avó. O mesmo se passa com Hélida, que se refere a uma aprendizagem, na infância, que se dá por contraponto entre a rigidez e a seriedade da avó e a afetividade e a leveza do pai, bem como pelo esforço e o trabalho da mãe. Na história de Rute, vemos a experiência da fé e da generosidade da família que incorpora à sua vida. Com Marta, percebemos o valor da disciplina aprendida desde cedo com os avós. Enfim, das relações familiares mais próximas da infância, ficam, para as professoras, indícios importantes da forma de ser e de estar, que vai sendo construída de diferentes formas ao longo da vida.

Mas das histórias de infância, além dos pais, sobressaem do núcleo familiar pessoas que ocupam um lugar central como educadores: os avós. Se a leitura partilhada de Guilherme Augusto Araújo Fernandes, como parte da metodologia da primeira entrevista realizada com as professoras, teve como objetivo iniciar uma reflexão sobre a memória, para muitas professoras, trouxe saudosas lembranças dos avós e das aprendizagens que tiveram com eles.

Eu fazia pão com a minha avó, porque a minha avó era uma pessoa muito meiga, deixava-me fazer de tudo, ensinava-me. Foi a minha avó que me ensinou a coser a máquina, ensinou-me a fazer primeiro uns aventais, que eram uns saquinhos em pano e tudo isso ela me foi ensinando. Portanto, esta rela- 
ção familiar também foi muito importante, $o$ ir ao moinho buscar a farinha para fazer o pão, tudo isso são percursos muito importantes, o ter um animal, a minha avó tinha uma burra para transportar as coisas, eu também já sabia lidar com a burra. Como se prendia, ir buscá-la e montá-la sozinha, isso são vivências que são importantes que nos dão conhecimento muito grande da realidade [...] (Carolina).

$\mathrm{Na}$ história de vida de Clara, encontramos uma geração de mulheres leitoras: sua avó, criada com a ajuda de um padre, torna-se grande leitora, assim como sua mãe e ela própria. Apesar das tentativas de interdição da escola primária, Clara consegue, já na adolescência, fazer florescer a aprendizagem de leitura do contexto familiar, em que o irmão não gostava da escola, mas era ávido leitor de banda desenhada, e sua irmã e sua mãe, leitoras de romances e literatura em geral. Em sua história, a força do contexto familiar consegue dar a volta às tentativas da escola de tornar a leitura um ato mecânico e desligado da vida. Na narrativa de Hélida, destacaram-se a história e a presença da avó educadora, que a levou para muitas atividades culturais e viagens, abrindo suas possibilidades de leitura do mundo, e do avô, o contador de "histórias da Glorinha", cheias de princípios que gostaria que a neta incorporasse à vida. Para Rute, a imagem das avós é lembrança da afetividade, da proteção, dos valores e da solidariedade, e, para Eloisa, a centralidade da primeira educadora:

A minha avó que foi, talvez, a minha primeira educadora [...] Gostava muito de contar histórias, e eu gostava de ouvi-las [...] Vovó contava muito a tradição oral portuguesa. Me parece, pelo menos com a experiência que eu tive com a minha família, são sempre aquelas histórias de fundo moral. Aprendi muitas liçōes de vida com a minha avó (Eloisa).

Mas as relações de aprendizagem/formação escapam do núcleo familiar e se tornam sempre mais complexas, incorporando aos cenários da infância a centralidade de pessoas, lugares e acontecimentos históricos. E entram nas histórias os amigos de Teresa que conheciam todos os mistérios das matas da África e, com ela, partilhavam momentos de brincadeira e aprendizagem em contato com a natureza; os amigos de Bela, com quem brincava na rua, nas noites quentes do Alentejo; e o ferreiro atentamente admirado por Isabel, em seu trabalho. 
$\mathrm{Na}$ história das professoras brasileiras, entram os vizinhos de Simone - filhos dos caseiros que moravam perto de sua casa e a remetem aos poucos momentos felizes da infância -, mas também a presença e a solidariedade de D. Glorinha, que entrou na vida de Rosangela e de sua família como vizinha e tornou-se uma "segunda mãe", uma pessoa que contribuiu de forma significativa para sua formação humana e pessoal. Quando crianças, as professoras aprenderam também com outras crianças, com pessoas idosas da comunidade e com vizinhos.

Os lugares também ensinam; das histórias, pulsam as aprendizagens com os lugares. Teresa traz a beleza da vida na África, o estudo das plantas, o conhecimento dos animais; Carolina fala com intensidade das experiências no "monte de sua avó", da exploração dos formigueiros, do contato com a natureza; Hélida afirma que falar de sua cidade é também falar de si, indicando a imbricação de sua história pessoal com a vida da cidade; na trajetória de Simone, vemos que as experiências de solidão na infância envolvem também a forma como descreve a cidade em que morava - um lugar frio, afastado de todos.

Para algumas professoras, as mudanças das aldeias para as cidades ou para diferentes lugares, motivadas especialmente pela necessidade de dar continuidade aos estudos, constituiram acontecimentos biográficos, rupturas que representaram dor, tristeza e dificuldade - como foi para Ana, Teresa e Marta -, e, para outras, vieram com o sentido de um caminho natural de crescimento e autonomização. Os momentos históricos também deixaram marcas importantes na formação pessoal das participantes da investigação. Cinco professoras portuguesas nasceram na década de 1950, portanto, suas narrativas de infância dialogam com o contexto da ditadura. Carolina fala da intensidade do trabalho dos tios e da lembrança de ficar na fila com sua avó, aguardando o ordenado, que era dado em alimentos.

Na juventude, também encontramos um peso significativo das experiências pessoais no processo de formação das professoras. A continuidade dos estudos, após a escola primária, gerou para as mais velhas, tanto em Portugal como no Brasil, deslocamentos afetivos e geográficos; já as mais novas, como Clara, Hélida, Rute e Simone, não sofreram rupturas e deram continuidade ao processo escolar sem necessidade de mudança de suas cidades. Todavia, em ambas as situações, o início de uma nova trajetória escolar possibilitou novos contatos, amizades, a ampliação do círculo de mediaçôes formadoras. Depois de turbulências/ adaptações, falam de um tempo feliz de troca, partilha e autonomização pessoal. 
Teresa destaca um momento importante de aprendizagem com um grupo de amigos que se reunia nas horas vagas para estudar diferentes textos, ler material de diversos partidos políticos, e atribui a esse espaço-tempo um papel significativo em sua formação política. Encontramos na trajetória de Hélida um movimento semelhante - junto com a turma do "mau-mau", ampliou sua visão de mundo, suas possibilidades de leitura crítica e cultural da realidade. Já na trajetória de Rute, a convivência com os amigos e grupos da igreja foi fundamental na aprendizagem do falar e na permanente reconstrução de sua forma de ver o mundo.

Do contexto mais amplo, as professoras portuguesas guardam a significativa memória do 25 de Abril de 1974:

Bem, eu já comecei a trabalhar depois do 25 de Abril [...], comecei a trabalhar em 1977. Era ainda logo no início, sim, em que ainda trabalhadores que estavam no monte a guarda tinha que intervir, porque os trabalhadores tomaram conta do monte, bom, foi numa altura conturbada, eu nunca tive problemas, felizmente [...] Aquilo eram os ânimos, assim, ainda muito exaltados (Bela).

Quando li este livro do José Saramago, vinham todas as vivências e informações que tinham sido registadas antes do 25 de Abril e, quando dava por $\mathrm{mim}$, muitas vezes, estava a chorar. Porque eu vi aquilo tudo que ele estava a escrever eu estava a vê-las, [...] Eu lembro das pessoas em uma bicha ${ }^{6}$ para receber, o meu tio mais novo não recebia ordenado. O que recebia era farinha, toucinho, linguiça, azeite era o que lhe davam no fim do mês, não o pagavam, os donos das terras não pagavam ordenados (Carolina).

[...] Então, quando se deu o 25 de Abril, entrou um grupo de jovens pelas salas a dentro e os professores não reagiram, coisa que a nós estranha muito, porque aquilo era muito, o professor era o detentor da sabedoria, era o professor que decidia, que mandava, que nós éramos meros ouvintes e obedecíamos. E, então, entraram pela sala a dentro e vamos lá para fora festejar, porque se deu uma revolução, que para mim aquilo era tudo estranho, para mim e para os meus colegas, para a maioria dos colegas. Então

${ }^{6}$ Fila, em português do Brasil. 
viemos todos para a rua fazer uma manifestação não sei para quê, nem por quê, nem por que não. Só quando cheguei a casa, mas sei que houve qualquer coisa muito importante e que mexeu e mexia com todo o sistema, com os [...], e mexeu com a escola e com os professores, sim senhor, portas abertas e tudo bem (Isabel).

A força de um acontecimento histórico afirma-se, na trajetória das professoras, como acontecimento biográfico. Como Isabel explicita em sua fala, quando crianças e adolescentes, viviam o contexto da repressão que perpassava os ambientes da família e da escola, mas só tomaram consciência disso quando veio a revolução, e uma forte ruptura instaurou uma nova etapa na história de Portugal, ruptura manifesta na escola, na postura dos professores, na sociedade em geral, consistindo também num momento importante de aprendizagem do sentido da liberdade por essas professoras. Em sua narrativa, Carolina afirma que, ao tratar desse assunto com seus alunos, toma como referência as memórias que guarda desse tempo, e suas vivências de menina e adolescente se transformam em história viva contada e recriada.

As professoras brasileiras também viveram um momento histórico significativo: a ditadura militar no Brasil; quatro nasceram antes de 1964, e duas, depois, mas todas viveram o ambiente da ditadura e, nos anos 1980, a abertura política. Identificamos, em algumas falas, referências da repercussão do clima democrático, especialmente nas experiências escolares. Hélida afirma:

[...] eu terminei em 1984, estava terminando, então ainda não se tinha grande projeto educativo, mas, ao mesmo tempo, tinha uma vontade de mudar, então, assim, eu não aprendi nenhum método de alfabetização, eles não me ensinaram nenhum, nenhum. Nenhum professor de didática me ensinou isso $[\ldots]$

$\mathrm{Na}$ continuidade de seu relato, a professora afirma o sentido sociopolítico de sua formação no nível médio, inclusive contrastando com a prática das escolas normais da época, ainda muito ligadas à perspectiva técnica. $\mathrm{O}$ mesmo sentido encontramos no relato de Teresa, professora portuguesa que viveu, no Curso do Magistério Primário, o momento do 25 de Abril e se 
lembra também da mudança de postura dos professores, que se tornaram mais abertos, davam maior liberdade aos alunos e de uma formação mais voltada para a conscientização. Já a professora Eloisa viveu a repercussão da democratização em seu curso superior:

Tive uma grande decepção no curso superior [...] no período que eu estudei era voltado para o marxismo e as correntes econômicas [...] E início de abertura, eu fiz história, tinha acabado aquele período forte de ditadura, a ditadura já estava mais branda, começou aquele movimento das 'diretas já, estava assim um período meio de transição. Eu tive uma colega que se formou pela mesma universidade que eu que ela teve aulas com militares com metralhadoras na sala de aula, ouvindo as aulas [...] (Eloisa).

Em fragmentos das narrativas, encontramos a complexidade de mediações entre o contexto sociopolítico, a dinâmica dos cursos de formação de professores e a experiência pessoal vivida pelas professoras brasileiras.

A escolha da docência coloca-se como movimento importante, construído de diferentes formas ao longo da vida, mas que se consolida na juventude, no momento em que a continuidade dos estudos exige uma escolha formal. Para Ana, Teresa e Carolina, desde a infância, a identificação com a escola e com os professores encaminha imagens e desejos em relação à docência; já para Bela, Isabel e Clara, o caminho para a docência foi uma construção feita "às avessas", pois as experiências da escola primária foram duras, e elas, com diferentes estratégias, tentaram a todo custo "fugir" desse caminho, mas uma conjugação de fatores foi definidora na escolha profissional. Na história de quatro professoras brasileiras, encontramos a peculiaridade e a força de serem filhas, netas, sobrinhas de professoras como elemento que, desde muito cedo, levou a uma aproximação da docência. Para Eloisa e Rosangela, a força da imagem social sobre a docência influenciou o desejo das famílias e delas próprias.

Na vida adulta, vão assumindo, em diferentes momentos, outros papéis sociais, como esposas e mães. Uma das principais aprendizagens da formação pessoal citadas pelas professoras coloca-se na articulação entre as demandas familiares e as intensas atividades docentes que sempre ultrapassam o tempo de trabalho na escola. Com os filhos, há sempre novos desafios e aprendizagens. Teresa afirma que aprende muito com os filhos de 7 e de 4 anos sobre novas 
formas de ser e de estar das crianças hoje. Para Hélida, o nascimento dos filhos gêmeos foi um acontecimento biográfico central que gerou uma nova e importante etapa de vida e formação.

Para concluir a análise das ênfases e configuraçōes da formação pessoal, destacamos a fonte dessas experiências formadoras: as pessoas. As professoras trouxeram a beleza e a simplicidade da aprendizagem humana, a necessidade do outro; foram "muitos outros" presentes nas narrativas, pessoas que, em diferentes situaçóes e contextos, assumiram um papel fundamental no fortalecimento, na continuidade ou na ruptura e na mudança de caminhos. Quando olhamos a coluna do eixo temático-cronológico referente às pessoas-chave, encontramos mais do que pessoas, educadores/as que ensinaram e aprenderam, que foram agentes de transformação, e nessa lista entram os pais, os avós, os irmãos, os tios, mas também os vizinhos, os amigos, aqueles que, não tendo laços de sangue, tornam-se irmãos, dividem e partilham os momentos difíceis. Encontramos também colegas e amigos de trabalho, alunos/as educadores, pessoas que desafiaram o desenrolar da vida das professoras e, muitas vezes, foram os responsáveis pelo desejo do novo. Em uma complexa tessitura, conjugando diferentes tempos e espaços, a formação pessoal das professoras traz, assim, o sentido de experiências vividas em partilha com pessoas, lugares e contextos.

Figura 4: Acontecimentos biográficos comuns na formação pessoal - infância

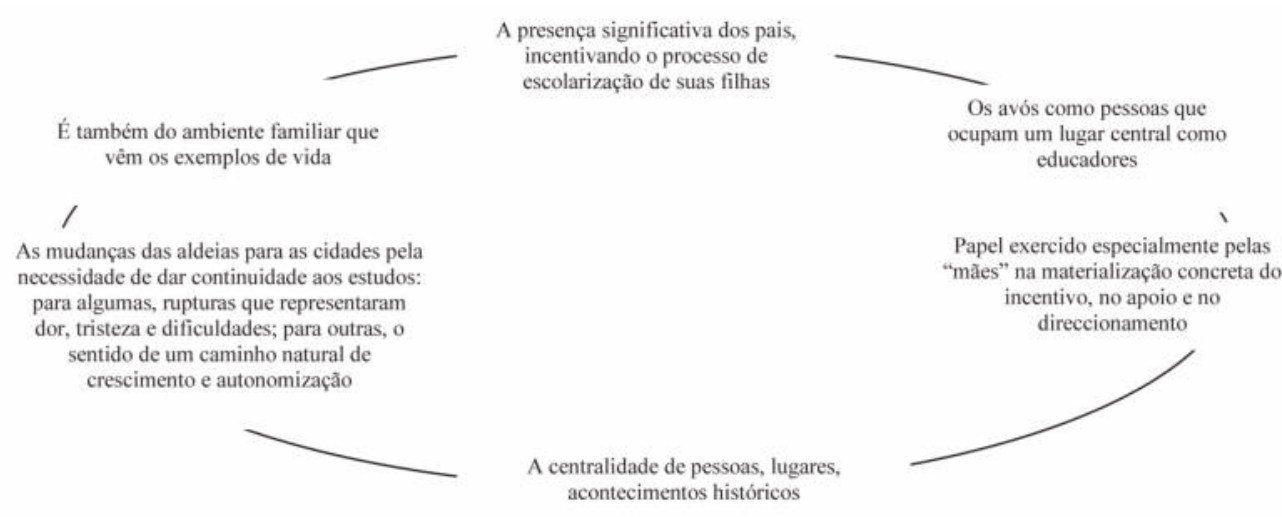


Figura 5: Acontecimentos biográficos comuns na formação pessoal - juventude e vida adulta

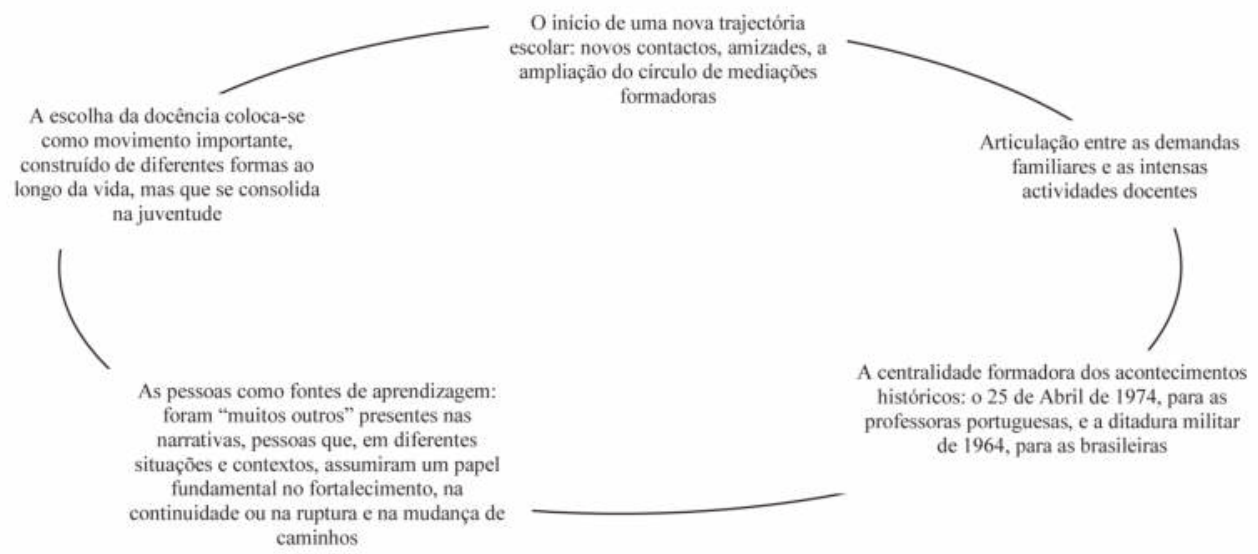

Memórias da trajetória escolar

Na complexidade de dimensões que tecem a formação docente ao longo da trajetória de vida, a escola, como instituição social historicamente voltada para transmissão/recriação do patrimônio cultural, exerce especial centralidade. A educação formal vem representada, na história das professoras, por uma diversidade de instituições - a escola primária, os ciclos subsequentes de formação, a Escola do Magistério Primário/Escola Normal, a licenciatural graduação, os cursos de formação continuada - que se afirmam como espaços-tempos significativos de formação humana, acadêmica e profissional dos/as professores/as.

Quanto à especificidade da formação de professores/as, no que se refere à dimensão acadêmica, encontramos, na literatura, referência a três grandes etapas: a pré-formação, que compreende a escolarização formal e experiências anteriores à formação profissional, especificamente voltada para a docência; a formação inicial, destinada à preparação profissional que habilita e assegura o exercício da docência; e a formação contínua, por meio de iniciativas formais que visam à continuidade dos processos de estudo e de aperfeiçoamento profissional. Em nosso estudo, tomamos como referência um conceito amplo que aponta o entrelaçamento indissociável entre esses diferentes momentos, 
espaços e tempos formativos. Logo, olhamos a trajetória das professoras participantes no sentido de perceber como essas diferentes etapas geram experiências formadoras que se apresentam e se inter-relacionam em diálogo.

Como afirmam alguns autores (Dominicé et al., 2000a, p. 232; Josso, 1988, p. 37), a palavra formação é utilizada em diferentes sentidos, referindo-se aos processos formais, institucionais (heteroformação) e ao movimento interno de transformação do sujeito (autoformação). Nesse sentido, é importante reafirmar que focalizamos a formação como experiência humana, que, por sua natureza, envolve a memória e a narração - a experiência mobiliza e transforma o sujeito e é ressignificada pela memória e pelo processo narrativo. Compreendemos, entretanto, que o sentido e a intensidade das experiências se dão na mediação com os contextos mais amplos, indicando interfaces entre o sujeito e as pessoas, os ambientes sociais, históricos e geográficos e os processos formais de profissionalização dos professores.

\section{Memórias da escola primária e continuidade dos estudos}

Observamos, na história das 12 professoras, que a formação docente começa muito antes da escolha da profissão ou do ingresso nos cursos de formação inicial; experiências vividas no espaço-tempo da escola, em situação de alunas, ao longo da infância e da juventude, vão, "a pouco e pouco", compondo imagens e reflexôes sobre o fazer educativo, sobre a docência. Saberes sobre o processo de ensino-aprendizagem construídos ao longo da experiência escolar tornam-se marcos significativos e referências de diálogo com as demais experiências que se desdobram ao longo da trajetória de formação.

Quadro 3: Data de nascimento e do início aproximado na escola primária

\begin{tabular}{|c|c|c|}
\hline Professoras & Data de nascimento & $\begin{array}{l}\text { Início aproximado de } \\
\text { realização da escola } \\
\text { primária }\end{array}$ \\
\hline \multicolumn{3}{|c|}{ Professoras portuguesas } \\
\hline Ana & 1956 & 1963 \\
\hline Teresa & 1959 & 1966 \\
\hline Carolina & 1956 & 1963 \\
\hline Bela & 1957 & 1964 \\
\hline
\end{tabular}




\begin{tabular}{|c|c|c|}
\hline Isabel & 1954 & 1961 \\
\hline Clara & 1979 & 1986 \\
\hline \multicolumn{3}{|c|}{ Professoras brasileiras } \\
\hline Hélida & 1966 & 1973 \\
\hline Rute & 1980 & 1987 \\
\hline Eloisa & 1954 & 1961 \\
\hline Simone & 1977 & 1984 \\
\hline Marta & 1943 & 1950 \\
\hline Rosangela & 1957 & 1963 \\
\hline
\end{tabular}

A experiência da escola primária, bem como da passagem para o Liceu, foi vivida, por cinco professoras portuguesas, durante a década de 1960, e por uma das professoras no final dos anos 1980 e início dos anos 1990, respectivamente. A indicação temporal nos ajuda a situar o ambiente histórico quanto à organização do sistema educativo e do ponto de vista filosófico, a levantar indícios sobre tendências e concepções que permeavam o campo educacional no momento em que as professoras participantes da pesquisa estudaram.

A ditadura implantada em 1926 em Portugal representou um retrocesso para o atendimento da demanda de escolarização e para a formação de professores. As décadas de 1950 e 1960 trouxeram, todavia, uma importante política expansionista, já que Portugal começou a sofrer pressões internacionais e procurou romper com seu isolamento em relação aos demais países da Europa. Houve, assim, uma revalorização da formação acadêmica dos professores e uma ampliação das escolas primárias e dos Liceus Normais. É nesse momento de expansão que cinco professoras portuguesas participantes da pesquisa ingressam na escola primária e depois dão continuidade aos estudos no Liceu. A professora Clara ingressa em outro momento, também significativo: o contexto da implantação da reforma do sistema educativo de 1986, que ampliou a escolarização obrigatória para nove anos, reorganizando o sistema educativo, agora distribuído em três ciclos: o primeiro com quatro anos, referente à antiga escola primária; o segundo com dois; e o terceiro com três. Do ponto de vista das concepçóes educativas, encontramos ao longo desse período uma forte presença conservadora, mas também já começam a 
se fazer sentir os impactos do movimento da escola moderna e de novas perspectivas educativas, que se afirmam especialmente com a reforma de 1986, e seu impacto sobre o currículo, com a proposta de novas áreas de estudo, novas formas de organização da dinâmica pedagógica das escolas e dos processos de ensino-aprendizagem.

Como nos referimos anteriormente, há maior diversidade etária entre as professoras brasileiras; nesse sentido, o ingresso na escola se deu ao longo das décadas de 1950, 1960, 1970 e 1980. Ao longo desse período, foram profundas as modificações do sistema educacional brasileiro, especialmente quanto à crescente e progressiva expansão da oferta de escolarização, que se torna perceptível a partir dos anos 1950, e quanto ao contexto da ditadura militar, que traz, em seu bojo, a reforma do sistema educacional, ampliando a escolarização obrigatória para oito anos, no então chamado $1^{\circ}$ grau, acrescida de mais três anos de formação em nível médio, no $2^{\circ}$ grau. Quanto às concepções educativas, temos, no espaço dessas décadas, mudanças paradigmáticas importantes, passando pela forte presença conservadora e pelos impactos do tecnicismo reducionista, com as reformas implementadas na década de 1970. Mas nos anos 1980 a força das abordagens crítico-emancipatórias, a partir especialmente das contribuiçóes de Paulo Freire, toma a escola como espaço de luta política e de transformação social.

Quais as mediaçôes entre esses amplos contextos sócio-históricos e educativos e as experiências vividas pelas professoras que fazem parte desta investigaçāo, quando foram alunas da escola primária e nos ciclos seguintes de escolarização? Observando não só a história das professoras portuguesas participantes da pesquisa, mas também os lampejos da história de suas famílias, percebemos que elas representam uma geração que, de fato, teve mais oportunidade de escolarização. Como vimos, os pais estudaram, no máximo, até a $4^{a}$ classe e, mesmo que ainda por meio de grande esforço das famílias, as professoras simbolizam uma geração que consegue, com mais facilidade, concluir estudos em nível médio. Mas é importante frisar que representavam ainda um quantitativo pequeno de estudantes que davam continuidade aos estudos, especialmente quando nos referimos à população que morava nas aldeias. Essas comunidades só tinham escola até a $4^{a}$ classe, o que exigia das famílias o esforço de enviar os filhos às cidades próximas e os sustentarem, ou, como aconteceu em alguns casos, o esforço de toda a família mudar-se para que os filhos pudessem dar continuidade aos estudos. 
Do ponto de vista da prática pedagógica, a narrativa das professoras é rica, ao mesmo tempo que identificamos na filosofia e na prática conservadora um pano de fundo predominante - encontramos, na experiência pessoal de cada professora, diferentes coloridos e imagens sobre as experiências vividas na escola primária, assim como faíscas de possibilidades instituintes.

$\mathrm{Na}$ narrativa de Bela, Isabel e Clara, encontramos as cores mais fortes e cinzentas: a escola como uma "seca", 7 marcada por rígidas práticas disciplinares e pedagógicas - a necessidade de pedir licença para pegar um lápis que cai no chão; a presença da palmatória e dos gritos da professora; a segregação dos alunos e o tratamento diferenciado dos que sabem e dos que não sabem; a escola como lugar de obrigação e castigo; um ensino conservador, autoritário e distante dos alunos, produzindo a interdição do desejo de estudar. São essas palavras e expressões fortes que definem, para as três professoras, a imagem da escola que viveram quando alunas. É interessante destacar que Clara passa por sua experiência escolar já no final dos anos 1980, mas o relato de sua experiência como aluna a aproxima de Bela e de Isabel, que foram alunas da escola primária no início dos anos 1960; ela mesma afirma que sua professora era nova, estava no início da carreira, "mas era uma professora antiga, a antiga portuguesa, ao fim e ao cabo, porque ela era nova, mas uma professora completamente ultrapassada, completamente antiquada, régua, tudo um rigor”.

Por indícios, encontramos no relato de Ana e Carolina a presença da mesma perspectiva conservadora. A forma como narram traz, entretanto, cores mais amenas, que parecem vir filtradas pelo relacionamento pessoal estabelecido com a professora, produzindo, para elas, uma experiência diferenciada: apesar do rigor, certa afetividade as liga às professoras, indicando novos sentidos para a experiência escolar e produzindo filtros e censura dos relatos que envolvem suas antigas mestras. Assim, percebemos que Ana não busca em sua memória as práticas que, tradicionalmente, descrevem a educação conservadora, mas, em outra direção, vai ao encontro de lampejos de práticas que até hoje a inspiram, como a cooperação, a entreajuda e o intercâmbio com alunos de outras escolas.

Outro aspecto significativo é que Bela e Carolina foram amigas de classe, estudaram com a mesma professora, contudo, as experiências vividas por cada uma delas trazem sentidos opostos para a experiência escolar: a "seca"

${ }_{7}$ Expressão portuguesa que indica algo cansativo e desinteressante. 
se contrapõe à aceitação e ao envolvimento. Por um lado, podemos levantar a hipótese de que a afeição entre Carolina e a professora fez sua experiência e seu olhar sobre o passado serem diferenciados da perspectiva de Bela. Por outro, a mencionada oposição se justifica pela presença de diferentes formas de ser e estar - Bela define a si própria por sua energia e vivacidade, enquanto Carolina se apresenta como uma pessoa tranquila que faz tudo com muita calma; Bela se sentiu reprimida pela escola, Carolina cumpre as regras sem se sentir cerceada por isso.

Vamos, assim, na análise dialogada entre as professoras, reafirmando que tanto a prática educativa como a experiência pessoal são sempre situadas, falam de contextos, mas falam especialmente de como as pessoas interagem e estabelecem mediações com esses contextos. É assim que, na África, Teresa vive uma experiência escolar especial: os alunos se colocam como sujeitos sob a orientação da professora, pesquisam e apresentam temas do conteúdo para os colegas, aprendem em contato direto com a natureza, aproveitando os recursos que têm disponíveis, como a areia da praia, para as atividades de ortografia; estabelecem uma relação próxima entre a professora e a turma. Alguns professores eram missionários que vinham de outros países; outros eram africanos e pareciam carregar em sua prática a influência de uma matriz filosófica e pedagógica diferenciada do conservadorismo predominante.

As três professoras brasileiras que foram alunas da escola primária nos anos 1950 e 1960, Marta, Eloisa e Rosangela, apresentam uma experiência escolar que as aproxima das professoras portuguesas: uma forma "antiquíssi$m a$ ", que envolvia: a) para Marta - decorar tabuada, saber ler soletrando, rigidez na disciplina, o uso da régua, o castigo para quem não soubesse ou não fizesse as tarefas de casa, o trabalho com uma amplitude de conteúdos como ler, escrever, fazer contas, tabuada, história, geografia, trabalhos manuais; b) para Eloisa - uma escola altamente repressora, "uma instrução formal boa, preocupação com a escrita, muito ditado, muita coisa para estudar, decorar, um excesso de informaçôes e uma repressão muito grande, 'magister dix', todo mundo caladinho, se virasse para o lado, castigo"; e c) para Rosangela - "uma professora ótima, muito brava, botava de castigo se não soubesse a tabuada, botava em pé”. Na experiência das professoras, entretanto, o rigor da escola primária não gerou uma reação negativa ou de estranhamento, como vimos com as professoras portuguesas, mas admiração e agradecimento pelo aprendizado da disciplina. 
Hélida e Rute viveram a experiência como alunas dos primeiros anos do ensino fundamental nas décadas de 1970 e 1980, respectivamente, e as duas apresentam um relato da escola como lugar de alegria, aprendizagens e amizades. O método de alfabetização foi o da "abelhinha", e as duas guardam lembranças positivas desse tempo. Já Simone, que estudou também nos anos 1980, mas em um colégio religioso, muito tradicional, lembra-se de cópias e de práticas conservadoras; esse foi um período cinzento por questôes familiares e porque teve muita dificuldade de adaptação à escola.

Olhar a história de vida das professoras na perspectiva de um diálogo nos confronta, desafia e ensina. Se em uma análise histórica e filosófica encontramos referências balizadoras das concepções e práticas educativas que caracterizam diferentes contextos, observamos que as experiências concretas de alunos/as e professores/as extravasam essas balizas e instituem uma configuração própria e peculiar. É assim que observamos uma professora, no final dos anos 1980, desenvolvendo uma ação educativa que caracteriza o conservadorismo de décadas anteriores e professores/as que na África, nos anos 1960 , realizam, de forma instituinte, um processo educativo voltado para a aprendizagem em partilha. São as pessoas que, na mediação entre suas histórias e contextos, vão tecendo diferentes formas de viver a docência e o processo de ensino-aprendizagem. Observamos também que a repercussão das experiências na vida de cada sujeito depende de sua subjetividade; um mesmo episódio e o mesmo ambiente de sala de aula podem gerar, como no caso de Bela e Carolina, o sentimento de cerceamento ou a conformidade voluntária.

Mas que imagens da prática educativa e da docência ficaram da experiência escolar de alunas para as professoras participantes da pesquisa? Em que medida essas imagens se relacionam com a forma como se veem hoje professoras? Tomando a experiência das professoras portuguesas Bela, Isabel e Clara em diálogo com as professoras brasileiras Marta, Eloisa e Rosangela, observamos movimentos que as unem e que as singularizam. Todas relataram experiências de práticas conservadoras, entretanto, enquanto estas geraram, para as primeiras, reação e contraposição crítica, para as demais, proporcionaram aceitação e admiração. As professoras portuguesas narram a experiência como alunas na escola primária com cores cinzentas, que expressam o sofrimento e o bloqueio frente ao processo de aprendizagem; nenhuma das três deseja, inicialmente, ser professora, pelo contrário, Bela e Isabel lutam, tentam fugir. Quando, por meio de diferentes caminhos, decidem ceder, fazer o curso do 
magistério e seguir a profissão docente, tomam a experiência de alunas, a imagem da docência construída na infância, como referência a contrapelo, ou seja, desejam e procuram com toda intensidade construir uma prática diferente da que vivenciaram quando eram alunas. A imagem da professora primária coloca-se como referência inversa à forma de ser e de estar que procuram construir para si na docência:

E, depois, tive essa professora, que era extrema, eu acho que ela exagerava, ela era de uma exigência, de uma [...] era mesmo assim, pronto. Isto antes, no regime fascista, isto era mesmo assim, um rigor enorme, uma disciplina [...] E, então, eu tive sempre presente que, para os meus alunos, eu quis sempre que eles não achassem a escola enfadonha, aborrecida, que gostassem de estar e esforço-me nesse sentido, sempre tenho tido isto muito presente (Bela). ${ }^{8}$

Quando eu me decidi ser professora, eu agarrei-me a uma ideia que ainda hoje me orienta neste papel de orientadora educativa, eu nunca poderia ser igual ou semelhante à minha professora (Isabel).

[...] Agora o $1^{\circ}$ ciclo, para mim, pensava, lembrava-me da minha professora e pensava: só espero não me tornar como ela foi (Clara).

Vemos, na fala de Bela, uma associação entre as práticas conservadoras e o regime fascista e, como observamos em item anterior deste capítulo, a instauração da democracia coloca o "25 de Abril” como símbolo de outro momento da sociedade portuguesa, a busca de afirmação da liberdade invade também a escola e, no imaginário das professoras, compóe sinais de outras práticas educativas que desejam construir. Já para as professoras brasileiras Marta, Eloisa e Rosangela, o rigor disciplinar e a metodologia da escola conservadora constituem referências positivas que reatualizam e trazem como referência de suas concepções e ações educativas:

[...] mas quando eu cheguei aqui [...] Era uma turma que estava rejeitada por todo professor, era uma turma brava, mas eles eram impossíveis. Mas eu, como tinha o gênio da minha avó, porque a minha avó, aluno com ela não

8 Continuamos a citação desse trecho da fala da professora em sua biografia educativa. 
piscava o olho, porque ela chegava junto, mas em dois meses eu pus a turma aonde eu queria, não parecia nem que tinha aluno na sala de aula (Marta).

Em um momento de dificuldade, com uma turma muito complicada, Marta busca referências na prática de sua avó professora. Já Rosangela foi aluna de Marta e, em diversos momentos de sua narrativa, reafirma que busca nas imagens docentes, construídas na infância, a referência de sua forma de ensinar:

Lembro como a D. Marta nos ensinava, [...] Eu trabalho igual eu recebi, eu trabalho igualzinho a D. Marta passou pra mim, D. Rute, minhas professoras de primário [...] Mas eu procuro buscar, eu me aperfeiçoo, eu estudo. Eu fiz é o adicional, mas eu procuro retratar tudo da minha infância, do jeito que eu aprendi, foi fácil demais. Então, eu acho que vai ser fácil para os meus alunos e tenho me dado muito bem, graças a Deus [...] muitas coisas eu busco lá da minha infância.

Para explicitar sua forma de ensinar, Rosangela fala da busca de constante formação, do curso adicional, mas coloca como referência central as imagens construídas na infância, na prática de suas primeiras professoras. Da mesma forma, Eloisa narra as práticas disciplinadoras do ensino fundado na memorização, mas afirma não reclamar, pois guarda desse momento a importante aprendizagem da disciplina.

A presença de práticas educativas instituintes aparece também nas narrativas como referências fundamentais. Mesmo no contexto de um ensino tradicional, Ana faz o relato do trabalho a pares e da entreajuda como práticas que incorporou à sua ação docente; Teresa cita positivamente as imagens da escola primária na África, procura construir uma prática muito ligada aos alunos, aos seus interesses. No contexto brasileiro, Hélida e Rute lembram -se com saudade dos tempos do ensino fundamental, viveram experiências felizes e se mobilizam, ao longo da trajetória de formação e de prática docente, no sentido de construir alternativas de aprendizagem para seus alunos. Já Simone viveu tempos sombrios na escola, mas, como professora, busca reinventar as práticas, fazendo do processo de ensino-aprendizagem um novo desafio para si mesma e para seus alunos. 
Considerando a formação como trama e tessitura pessoal, ao olhar as histórias das professoras como alunas da escola primária, em diálogo com suas concepções e práticas educativas, encontramos sentido na singularidade dos percursos. Para umas, a experiência conservadora da prática educativa vem como "imagem inversa". Elas procuram com toda intensidade "fugir" da imagem docente representada por suas professoras; para outras, essa experiência afirma-se como referência inspiradora. Práticas consideradas instituintes são narradas, embora sempre em diálogo com o que as professoras até hoje guardam como experiências formadoras que mantêm como referência de suas concepções e açôes educativas. Entretanto, essas singularidades, em seu conjunto, afirmam na trajetória das professoras a experiência da escola primária como espaço-tempo fundamental no processo de formação docente.

A continuidade dos estudos no Liceu e nos ciclos subsequentes representou um marco na trajetória não só escolar, mas de vida. Esse acontecimento da caminhada escolar contribui significativamente para o despontar da adolescência, trazendo uma pluralidade de dilemas. As professoras portuguesas e brasileiras que ingressaram na escola primária nos anos 1960 viveram a experiência dos quatro anos de estudo e a necessidade de preparação especial para a realização de exames, visando à admissão ao Liceu, em Portugal, e ao ginásio, no Brasil, ou seja, entre o término do primário e a continuidade dos estudos, havia uma interrupção, um estrangulamento no sistema educativo, e muitos ficavam apenas no primário. Em suas histórias, a passagem para o novo ciclo de estudos constituiu um movimento importante na instauração de uma nova etapa de vida e formação, inclusive pela necessidade de deslocamento geográfico em muitos casos.

Ana, Teresa, Carolina, Bela, Isabel, Eloisa, Marta e Rosângela passaram por um processo de preparação, realizaram provas e, com a aprovação, deram continuidade aos estudos - processo que se deu com muito esforço e investimento de seus pais. Esse acontecimento foi relatado por elas como significativo, que gerou expectativas e abriu novas possibilidades para o futuro. Já Clara, Hélida, Rute e Simone não fizeram exames. Os sistemas educativos já tinham passado por reformas, e a escolarização obrigatória havia sido ampliada; entretanto, a diferença na forma de organização da prática educativa com muitos professores e disciplinas também gerou, para as professoras mais novas, o sentido de ruptura e o instaurar de um novo ciclo. 
Para três das professoras portuguesas, a mudança representou a libertação das práticas extremamente castradoras da escola primária. Teresa fala de professores fabulosos e, após o 25 de Abril, sentiu uma grande liberdade; para Isabel, essa mudança significou um momento de alívio, de libertação de um peso pesado; e, para Clara, a passagem de um processo de formação morno e morto à descoberta do prazer da aprendizagem - da formação como obrigação, passou a viver a formação como prazer. Bela, por sua vez, vive a continuidade das mesmas práticas castradoras, encontrando na educação física a possibilidade de extravasar sua vivacidade.

As histórias das professoras brasileiras revelam dificuldades de adaptação pela mudança de escola, pela natureza da prática educativa. Eloisa passou por um "choque nervoso", pois mudou de uma escola particular de freiras, um mundo protegido e quieto, para uma grande escola pública, em que passou a conviver com diferentes classes sociais; Rute e Simone tiveram dificuldade de integração com os novos colegas e professores.

Das experiências escolares, alguns/algumas professores/as desse período ficam como referências importantes, como a professora de geografia de Clara: uma docente disponível, que gostava de ouvir os alunos, de entrar no universo deles, desenvolvia um ensino contextualizado nos acontecimentos da atualidade, puxava pelo interesse dos alunos, deu contribuição a diversos grupos da turma, na organização de esquemas de estudo. Rute também cita uma professora de geografia que tinha uma prática muito tradicional, mas demonstrava grande envolvimento com a docência e incentivava os alunos. Eloisa se lembra de professores comprometidos, maravilhosos, mas também da prática conservadora; reconhece que construiu muitas aprendizagens sob a égide do medo: "Eu era muito nervosa, eu tinha muito medo, eu tinha problemas de estômago". Marta lembra-se de uma prática pedagógica rígida no ginásio: "[...] aquela rigidez, aquela coisa horrível, o aluno tinha até medo de olhar pro lado". Rosângela atribui ao ginásio um importante período de construção do conhecimento: "Tudo que eu sei eu trouxe essa bagagem do ginásio. Porque no normal eu, assim, adquiri um pouco mais de conhecimento, claro, mas tudo que eu sei eu aprendi no ginásio". Observamos, de diferentes formas, um tempo de reconfiguração pessoal e de enfrentamento de novos desafios.

Assim, no olhar para a trajetória escolar anterior à escolha da docência e à formação específica, chamada de "inicial”, encontramos na história das 
professoras tempos e espaços férteis de aprendizagem e formação, de constituição de imagens e referências sobre a docência que, com a força de experiências, ficam e dialogam com os estudos profissionais posteriores, bem como com as demandas e os desafios da trajetória docente no cotidiano da escola.

\section{Formação inicial}

Sem ignorar o peso de factores de socialização profissional anteriores, postos em relevo por autores como Anderson (1974) ou Zeichner (1985), entendemos por formação inicial de professores o início, institucionalmente enquadrado e formal, de um processo de preparação e desenvolvimento da pessoa, em ordem ao desempenho e realização profissional numa escola ao serviço de uma sociedade historicamente situada (Estrela, 2002, p. 18).

A escolha da docência levou as professoras à realização de cursos de formação inicial, na maioria dos casos, em cursos de nível médio - Escola do Magistério Primário, em Portugal, e Escola Normal, no Brasil. Apenas uma professora portuguesa teve, no ensino superior, a primeira formação profissional, tendo iniciado o curso já nos anos 1990. Todas as demais tiveram no curso de nível médio a primeira profissionalização e realizaram, posteriormente, a licenciatura, por meio de cursos de complementação, no contexto da reforma do sistema educativo que trouxe a unificação da formação de todos os docentes em cursos de licenciatura em Portugal. As seis professoras brasileiras fizeram o Curso Normal, e quatro deram continuidade aos estudos por meio da graduação.

Qual a importância da formação específica para o magistério realizada em nivel médio pelas professoras portuguesas e brasileiras participantes da pesquisa? Quais as contribuiçôes/impactos da "formação inicial" nas formas de ser e estar das professoras?

Cinco professoras portuguesas realizaram o Curso do Magistério Primário no início da década de 1970, no ambiente de transição da ditadura para o período democrático, fato que aparece de diferentes formas na história de cada uma. Em suas narrativas, encontramos atribuição de importância ao Curso do Magistério Primário como uma etapa significativa de construção de saberes sobre a docência. Um dos aspectos destacados com grande relevância é a realização do estágio, a aproximação efetiva da escola e da prática edu- 
cativa, momento em que retornam, como futuras professoras, a um espaço que conheceram como alunas. Em Portugal, as escolas de formação de nível médio - hoje, por meio de universidades e institutos politécnicos - estabelecem articulação com as escolas do ensino básico; assim, alguns professores assumem o papel de cooperantes, recebendo e orientando os estagiários.

$\mathrm{Na}$ trajetória de Ana, o terceiro ano do curso esteve muito voltado para a prática, e foi Maria Antónia, sua professora primária, que atuou como cooperante de sua formação, contribuição reafirmada por sua narrativa: "E ela ajudou-me muito, engraçado, mais uma vez eu era aluna dela. Já numa outra situação". Teresa também se lembra do estágio como um momento importante de sua formação e ressalta a postura da professora cooperante. Sua narrativa sinaliza, entretanto, uma questão recorrente: qual a contribuição da "formação inicial" para o desenvolvimento da prática profissional?

E depois tive também as pessoas que estavam à frente das turmas em que estagiei, que eram orientadoras, eram fabulosas, eram pessoas que nos compreendiam, que criticavam, mas era para depois nós não cairmos nesse erro e mostravam-nos diferentes caminhos, nós seguíamos aqueles que achávamos o mais correcto e o que se adaptasse mais à nossa forma de ser e de estar. Cada um de nós, depois, optaria por aquilo que nos indicassem, mas elas também foram extraordinárias, porque eram extremamente abertas, eram dóceis, tinham uma relação com a turma fabulosa, os miúdos ficavam à vontade [...] Os miúdos circulavam, andavam à vontade, havia regras, sim, senhor, que tinham que cumprir, não podiam falar alto, não podiam estar a gritar, podiam, sim, senhor, deslocar-se do local e ir até à casa de banho, desde que não tivesse outro miúdo lá. Portanto, havia regras que eles sabiam perfeitamente definir e interiorizaram de tal forma que eles cumpriam e isso tudo ajudou, ajudou na formação, depois, a realidade cá fora é outra, não é? Aquilo que nós fazemos lá dentro, comigo aconteceu, isso era muito, muito bonito até porque as turmas eram óptimas (Teresa).

Vemos, na fala de Teresa, indícios de uma contradição entre a realidade da turma em que estagiou e das turmas com as quais trabalhou, posteriormente, já como professora: "Em termos de turmas, a realidade é completamente diferente, completamente diferente. Pareceu-me a mim que eu estava 
a fazer uma nova aprendizagem". Carolina também cita a importância do estágio e da professora cooperante em sua formação:

Quando comecei a fazer o estágio, ah, senti-me muito orgulhosa, parecia que já era professora, aquelas coisas que nos parece [...] O estágio fixo - lembro-me perfeitamente da professora, da sala, lembro-me que era uma professora muito calma, muito meiga para as crianças com quem eu podia estar de forma, à vontade, tranquila, expor-lhe as dúvidas, as dificuldades, que ela estava sempre pronta a ajudar. Lembro que também uma aluna dessa turma que era uma criança muito carenciada e foi o primeiro contacto que eu tive com uma carência ao nível que de facto eu verifiquei (Carolina).

Um tempo importante de aproximação da docência e de diferentes realidades. Clara realizou estágio na licenciatura e teve contato com uma realidade social complexa, crianças que viviam em uma área de risco e extremamente carente. A prática pedagógica repetia o que vivenciara como aluna da escola primária:

A professora que ia me orientar era parecida com a que eu tive, infelizmente, é uma professora que só com o olhar as crianças ficavam tipo duras, tipo pedras. Não sei o que que elas faziam, nunca vi ela tocar numa criança enquanto estava lá, porque elas tinham um medo terrível, ela olhava e elas, só com o olhar, mas era medo, não era respeito. Não havia relação afectiva, ela não os deixava aproximar dela, era uma distância, ela estava num pedestal e estavam ali e como eram crianças muito complicadas, com higiene não havia muita, aqueles problemas todos familiares, eram crianças muito, muito carentes, muito carentes. Então, quando estavam os estagiários, aquilo para elas era a melhor coisa [...] (Clara).

Foi nesse contexto do estágio que uma aluna se tornou educadora, uma menina que se aproximou de Clara, mostrando que a relação entre professor e aluno pode ser próxima e afetiva. Mas, além da centralidade do estágio, encontramos na narrativa de duas professoras ênfase na formação técnica como uma contribuição relevante. Carolina e Bela, que fizeram juntas o Curso do Magistério Primário e, anos depois, o curso de complemento de formação, destacam a importância das aulas de didática na formação inicial, pois não 
ficaram só na teoria, mas trabalharam com ênfase na experimentação e na demonstração. Bela, que atua como professora cooperante, sente falta dessa formação nos alunos estagiários que recebe em sua sala de aula. Ana fala de uma formação voltada para muitos trabalhos manuais, tendo de contar com a ajuda de sua irmã. que era muita habilidosa. Teresa também destaca a ênfase no desenvolvimento das habilidades de desenho.

Isabel viveu o Curso do Magistério Primário no momento pós-revolução e sentiu uma grande desestruturação dele, como se os professores estivessem perdidos num momento de incerteza e reestruturação. Sentiu falta de uma preparação específica para o processo de ensino-aprendizagem da leitura e da escrita e, de maneira geral, não se sentiu preparada para a sala de aula:

[...] Porque, por exemplo, eu tinha a minha irmã como referência, minha irmã enquanto esteve no magistério os dois anos [...] eu notava, pela nossa conversa, que ela veio muito mais - apesar de não vir preparada, porque ninguém vem preparada para, ela vinha muito mais preparada para enfrentar uma classe que eu. Porque eu foi naqueles anos que andamos ali, percebes? Quase cobaias, nós fomos as cobaias do Ministério, do sistema educativo.

Da mesma forma, Clara, que cursou a licenciatura, também fala de um sentimento de lacuna e de perda de tempo em relação à formação acadêmica:

[...] $\mathrm{Na}$ Universidade não tive nenhum professor que me marcasse muito, a nível de tirar a licenciatura para o $1^{\circ}$ ciclo, não tive. Tive uma professora de matemática que nos deu muitas dicas para implementar na prática, mas foi muita teoria e o que eu me lembro é teoria e foi recente, é teorias, teorias e muito poucos ensinamentos para o dia a dia. E ainda sinto, ainda sinto todos os dias, mas senti muitas lacunas e senti que perdemos tempo ali na universidade, foi uma perda de tempo completa em muitas questões.

As professoras brasileiras passaram pelo Curso Normal em diferentes contextos. Marta o realizou entre os anos de 1957 e 1960, e suas memórias falam de um curso benfeito, em que quem não soubesse não passava, um curso que oferecia muitas oportunidades de contato com a sala de aula e que deu base para o desenvolvimento de sua prática educativa: “[...] tinha que repetir novamente pra poder sair daí com base pra enfrentar uma sala de 
aula”, era um curso muito rígido, mas que preparava o aluno para enfrentar a sala de aula. Ao final do curso, os alunos faziam prova oral e escrita, recebiam o registro do MEC no diploma e podiam lecionar até a $5^{\mathrm{a}}$ e a $6^{\mathrm{a}}$ séries. Em comparação com o ginásio, o normal foi um tempo de maior liberdade e amizade dos professores em relação aos alunos.

Rosangela fez o curso no início da década de 1970: "Foi ótimo, um curso muito bom mesmo e ali no normal é que eu fiquei preparada pra vida, pra educar". No decorrer dele, confirmou a escolha da docência como profissão, um "curso maravilhoso, que fiz com muito carinho". Aos poucos, as matérias foram ficando mais pesadas, muitos estágios eram realizados no próprio colégio, "o curso era bem rígido", as matérias principais eram didática, pedagogia e psicologia. No final do curso, sentiu grande insegurança, questionando se estaria preparada, e conversou com a professora de metodologia:

'Estou preparada Dra.?' 'Está minha filha, só você não esquecer nada'. Que eles comentavam: 'A Rosangela é ótima, vai ser uma ótima profissional'. Que lá mesmo eu dava aula, comecei o segundo ano, dar estágio, dava aula para a $1^{\underline{a}}$ série, alfabetização. Porque lá é assim, até hoje tem de $1^{\underline{a}}$ a $4^{\underline{a}}$, tem o curso normal, pra dar o estágio lá dentro mesmo. Preparando aquelas aulas, ah, eu vinha pra casa, às vezes, a energia aqui era ruim, faltava, botava as lamparinas, ficava preparando as aulas. Quer dizer, tinha que preparar tudo certinho pra não dar furo.

Eloisa fez o curso também no início dos anos 1970. Sua experiência ressalta, entretanto, uma crítica à excessiva referência técnica, um curso "chato", que dava mais ênfase às didáticas do que ao conteúdo: "Então, eu ficava muito desgastada, ficava irritada, e nós fazíamos trabalhos maravilhosos, cartazes lindos, álbum seriado, quadro com valor de lugar, tudo isso contando pontos, inclusive, para aprovação ou reprovação".

Hélida passou pelo Curso Normal na década de 1980; Rute e Simone, nos anos 1990. Na experiência de Hélida, a força do contexto de abertura política no Brasil influenciou uma prática pedagógica mais crítica e política, diferente da ênfase técnica, ainda predominante na época. Foi um tempo de intensas experiências com os professores, leituras e discussões. Simone, entretanto, fala de um curso com ênfase técnica, mas que traz boas recordações, pois foi uma etapa de realização pessoal, de confirmação da escolha da docên- 
cia como profissão. Destaca a importância do estágio, pois trouxe o choque com a realidade e com as tramas complexas do processo educativo. Afirma, no entanto: "De experiências de coisas que eu uso, que eu aprendi na escola normal, foram poucas". Para Rute, o curso foi um tempo de crescimento pessoal; ela foi representante de turma, experiência que contribuiu para a necessária aprendizagem de falar em público e mediar conflitos da turma.

Colocando em diálogo as narrativas das professoras portuguesas e brasileiras, percebemos campos de contato e singularidades. Encontramos experiências que reforçam o sentido da formação inicial na preparação para a docência, ${ }^{9}$ entretanto, de diferentes formas, o reconhecimento da insuficiência do curso frente às demandas do dia a dia da profissão. ${ }^{10}$ Ainda neste capítulo, a análise da contribuição da experiência profissional no processo de formação trará indícios de como os conteúdos construídos no curso de nível médio assumem novos sentidos e se transformam quando entram em contato com os desafios do cotidiano e, nesse momento, outros agentes e conhecimentos entram em cena na complexa tessitura da formação. Mesmo considerando a diversidade temporal - professoras formadas entre as décadas de 1960 e 1990 - e geográfica - Portugal, Brasil, regiōes urbanas e rurais -, um aspecto recorrente une as narrativas sobre a formação inicial: $a$ ênfase técnica. Assumem relevância a formação didática, em sentido restrito, muitas vezes relacionada ao desenvolvimento de técnicas e habilidades manuais, em contraposição a poucas referências a uma formação mais ampla e política. Como singularidade, sinalizamos o lugar do estágio na formação das professoras. As brasileiras falam do estágio, mas na narrativa das portuguesas esse espaço-tempo de formação assume especial centralidade, indicando um acontecimento biográfico importante na trajetória de formação profissional.

\section{Formação contínua}

O investimento no processo permanente de formação dos/as professores/as, em Portugal e no Brasil, assume diferentes definiçóes legais, bem como características próprias. Nesse momento, analisando a biografia educativa das professoras participantes, somos levados à procura de sentidos des-

9 Como ressaltam a fala de Ana, Teresa, Carolina, Bela, Hélida, Rute, Marta e Rosangela.

${ }^{10}$ Destacadas por Teresa, Isabel, Clara, Eloisa e Simone. 
sa formação na trajetória pessoal e profissional docente. Como dissemos no item anterior, das 12 professoras participantes da pesquisa, 11 passaram pela formação inicial em cursos de nível médio; nesse sentido, entendemos que todos os demais cursos, mesmo os de natureza acadêmica, como licenciatura/graduação e pós-graduação, colocam-se como formação contínua, já que foram realizados concomitantemente com o exercício da profissão. Buscaremos, assim, levantar alguns indícios sobre a dinâmica e os impactos desses movimentos formativos na narrativa dessas professoras. Tendo em vista uma ampla visualização de sua formação acadêmica, expomos um quadro-síntese:

Quadro 4: Formação acadêmica das professoras participantes

\begin{tabular}{|c|c|c|c|c|}
\hline $\begin{array}{l}\text { Profes- } \\
\text { soras }\end{array}$ & $\begin{array}{l}\text { Formação inicial } \\
\text { em nível médio - } \\
\text { Curso do Magis- } \\
\text { tério Primário / } \\
\text { Curso Normal }\end{array}$ & $\begin{array}{l}\text { Licenciatura / } \\
\text { graduação }\end{array}$ & Pós-graduação & $\begin{array}{l}\text { Cursos de forma- } \\
\text { ção contínua }\end{array}$ \\
\hline \multicolumn{5}{|c|}{ Professoras portuguesas } \\
\hline Ana & $\mathrm{X}$ & $\mathrm{X}$ & - & $\mathrm{X}$ \\
\hline Teresa & $\mathrm{X}$ & $\mathrm{X}$ & - & $\mathrm{X}$ \\
\hline Carolina & $\mathrm{X}$ & $\mathrm{X}$ & - & $\mathrm{X}$ \\
\hline Bela & $\mathrm{X}$ & $\mathrm{X}$ & - & $\mathrm{X}$ \\
\hline Isabel & $\mathrm{X}$ & $\mathrm{X}$ & - & $\mathrm{X}$ \\
\hline Clara & - & $\mathrm{X}$ & - & $\mathrm{X}$ \\
\hline \multicolumn{5}{|c|}{ Professoras brasileiras } \\
\hline Hélida & $\mathrm{X}$ & $\mathrm{X}$ & $\mathrm{X}$ & $\mathrm{X}$ \\
\hline Rute & $\mathrm{X}$ & $\mathrm{X}$ & - & $\mathrm{X}$ \\
\hline Eloisa & $\mathrm{X}$ & $\mathrm{X}$ & - & $\mathrm{X}$ \\
\hline Simone & $\mathrm{X}$ & $\mathrm{X}$ & $\mathrm{X}$ & $\mathrm{X}$ \\
\hline Marta & $\mathrm{X}$ & - & - & $\mathrm{X}$ \\
\hline Rosangela & $\mathrm{X}$ & - & - & $X$ \\
\hline
\end{tabular}

O quadro retrata o nível e as inserções de formação acadêmica das professoras e apresenta mediaçóes claras com o contexto sócio-histórico. Considerando a faixa etária das professoras, que, em sua maioria, nasceram entre as décadas de 1950 e 1960, antes das reformas dos sistemas educativos com alteração da exigência quanto ao nível da formação docente, tanto em Portugal 
como no Brasil, é natural que 11 das 12 tenham no nível médio a instância de formação inicial. Clara representa uma nova geração de professoras, que, agora, se encaminha diretamente para a licenciatura na docência de $1^{\circ}$ ciclo, como instância de formação inicial. No Brasil, o mesmo já acontece, entretanto, ainda temos o Curso Normal, em nível médio, em funcionamento, sendo o nível mínimo de formação exigido pela legislação. Observamos que, com exceção de duas professoras brasileiras, todas as demais cursaram, posteriormente, a licenciatura/graduação como complementação da formação inicial. As duas professoras brasileiras que não têm nível de formação superior nasceram nas décadas de 1940 e 1950, moram e desenvolvem a trajetória docente em um município da área rural, fatores que, naturalmente, dificultaram o acesso a esse nível de ensino, realidade que hoje, progressivamente, se altera. Entre as professoras brasileiras mais jovens e que residem na área urbana, a realização de cursos de pós-graduação indica uma tendência crescente. Outro aspecto significativo é que todas as professoras, mesmo as que já estão em final de carreira ou aposentadas, participaram de diferentes cursos de formação contínua.

Quando nos aproximamos da história das professoras portuguesas, encontramos uma recorrência: cinco fizeram cursos que foram denominados de Complementação, oferecidos aos professores já em exercício, quando a reforma do sistema educativo unificou a carreira docente e elevou a formação do bacharelato à licenciatura. Logo, encontramos em suas histórias professoras já experientes, com anos de exercício profissional e que voltam aos bancos escolares, dessa vez, em universidades e institutos politécnicos. Vamos começar, então, analisando as implicações dessa experiência na trajetória de vida e formação das professoras. A decisão de ingresso no curso não foi fácil, pois já viviam a intensidade de demandas da docência, do trabalho com suas turmas, bem como da vida pessoal em família. Assim, para todas elas, a realização do Complemento de Formação foi um desafio a ser vencido, exigindo grande esforço. Nas palavras de Teresa e Bela, encontramos a intensidade desse momento:

Portanto, trabalhava durante o dia, tinha o horário normal, na altura, entrava às nove e saía às quatro e, depois, ia para o curso à noite, entrava às seis e saía à uma da manhã... Com aulas e tínhamos no sábado até meio-dia. E, 
entretanto, nós fizemos, eu fiz e outras colegas, foi gratificante, foi bom, não foi fácil (Teresa).

E, então, para mim foi gratificante e aprendi imenso, gostei imenso daqueles dois anos muito sobrecarregados, porque saíamos da escola e íamos a correr para a universidade todos os dias até às nove e tal da noite, chegávamos a casa ainda tínhamos algumas coisas para fazer, preparar as aulas para os miúdos (Bela).

$\mathrm{Na}$ narrativa das demais professoras, encontramos este mesmo sentimento: foi um grande esforço, não foi fácil, mas foi gratificante. A decisão de fazer o curso gerou um primeiro movimento de reflexão. Por um lado, Ana vivia um momento de grande envolvimento com sua turma, não queria quebrar o ritmo de seu trabalho; por outro, a princípio, achava que não fazia sentido fazer outra formação, pois nem sempre os cursos se traduziam em ganhos para a prática; foram o apoio e o incentivo de colegas e o fato de ser professora cooperante da Escola Superior de Educação que a impulsionaram para o curso. Isabel fala também da dificuldade de ingresso, pois vivia um momento de grande envolvimento com o trabalho da escola. Mas, no contexto de uma "onda", quando os professores que tinham bacharelato precisavam complementar a formação, ela decidiu fazer o curso, assumindo o compromisso de não prejudicar seus alunos. Para Carolina, faltavam poucos anos para a reforma e, mesmo assim, foi em busca de novas aprendizagens que pudessem contribuir para sua prática e para a necessária valorização profissional.

As experiências ao longo do curso apontam o sentido comum anteriormente mencionado: a gratificação do esforço. As professoras levaram uma bagagem de experiências construídas na docência, e a complementação constituiu um importante espaço-tempo de reflexão e de consolidação de saberes.

[... é um enriquecimento pessoal, acaba por ser profissional, fiz muitas leituras interessantes, revi muitas coisas, abriu muitos caminhos, deu-me alguma força e alguma maleabilidade para fazer outras coisas, penso que nos dá força, que nos dá alguma solidez e é uma preparação diferente para fazer outras coisas. Sentimos um bocadinho mais fortes, passando por, foram dois anos, houve um enriquecimento muito grande, até nos trabalhos de grupo que fizemos [...] A experiência das aprendizagens foi muito boa. Senti-me reviver 
momentos de escola e senti que estava a aprender de novo, a aprender muitas coisas [...] E por sua vez também trazer de lá para cá, esta reciprocidade, esta interacção. Acho que nos enriquece sempre depois ficamos com um outro conhecimento, com um outro à vontade e estamos, sentimo-nos mais preparados. Acho que me ajudou, acho que foi o momento certo (Ana).

Portanto, ali, foi espectacular e os professores gostaram imenso de nós, porque nós fomos para ali mesmo de peito aberto a querer aprender, depois de tantos anos. E digo-lhe uma coisa eu, para mim, foi gratificante fazer aqueles dois anos, porque a prática nós tínhamos, vinte e tal anos de prática, mas há coisas que nós fazemos intuitivamente, porque já temos muita experiência e que eu, naqueles dois anos, percebi porque é que eu fazia, no que que aquela minha prática assentava, em que teorias, está a perceber? (Bela)

Nas narrativas, observamos que a realização do Curso de Complemento foi um momento importante na trajetória das professoras. Ana cita como um episódio significativo uma disciplina que favoreceu a escrita reflexiva sobre a prática; em diversos momentos da vida, fez registros de suas ações e a oportunidade do trabalho favoreceu um movimento de reconstrução do conhecimento sobre a docência. Carolina, que sempre guardou desenhos oferecidos a ela por seus alunos, pôde recuperar esse material para fazer um estudo a respeito do desenho infantil e envolveu-se muito nas atividades experimentais. Bela afirma que foi "a vertente de estudante que adorou”, pela relação positiva com os professores, o reencontro com antigas colegas do Curso do Magistério Primário, pela contribuição no "cimentar" de importantes aprendizagens. Cita como acontecimento significativo a realização de um trabalho de pesquisa sobre "Aprender no Alentejo", quando retornou à aldeia em que nasceu e analisou os processos de aprendizagem informais que se dão socialmente. Isabel fez uma formação voltada para a dimensão administrativa, "gostou de ir", mas sua narrativa não deu ênfase ao curso como acontecimento relevante, tal como observamos na fala das outras quatro professoras. De modo geral, podemos dizer, entretanto, que para as professoras a realização do Complemento foi um acontecimento biográfico de formação, constituindo um importante espaço-tempo de reflexão sobre a prática, de encontro e partilha com colegas e professores e de fundamentação de muitas aprendizagens construídas ao longo da docência. 
$\mathrm{Na}$ trajetória das quatro professoras brasileiras, a realização da graduação se deu mais no início da trajetória profissional: Simone concluiu o Curso Normal, ingressou como professora da rede municipal da cidade em que morava e iniciou, nesse mesmo ano, o curso de pedagogia; Rute começou o mesmo curso dois anos depois do término do ensino médio; Eloisa fez a graduação em história quando tinha seis anos de magistério; e Hélida ingressou também na pedagogia com 14 anos de exercício profissional.

Para Simone, o ingresso na graduação se deu como uma continuidade natural do Curso Normal, quando se identificou com o magistério, com a docência e foi uma boa aluna: "Aí fiz o vestibular, fui fazer faculdade - aí também fui uma boa aluna na faculdade, porque eu gostava. Aí já estava numa área que eu gostava. Eu gostava de tudo, já era a minha linguagem”. Para Rute, constituiu um período de grande esforço pessoal, pois estava iniciando uma nova etapa da vida com o casamento, investindo na construção de sua casa e iniciando a trajetória profissional, mas foi também uma experiência rica de formação. Hélida conta, em sua biografia, sobre o episódio peculiar que a conduziu ao curso superior: a reprovação inicial a fez desistir e passar anos longe dos bancos escolares, mas sempre participando muito ativamente de diferentes cursos de formação contínua. Foi, entretanto, a insistência de um amigo que a levou novamente ao vestibular e ao ingresso no curso de pedagogia:

Então ele dizia, convivendo comigo ele dizia: 'Você tem, você sabe tudo mesmo, você realmente tem esse conteúdo todo, só que você não tem papel para provar e você tem que ter papel' [...] Eu discutia, as pessoas não sabiam que eu não era graduada, ninguém que convivia comigo sabia [...] Porque eu discutia de igual para igual [...] porque eu lia, porque eu participava [...] Aí ele ficava me atentando: 'Você tem que fazer, você tem que fazer', aí eu resolvi tentar o vestibular e ainda era aquele vestibular que era especial pra professores $[\ldots]$ Eu fiquei em segundo lugar (Hélida).

A resistência inicial foi vencida, e a graduação veio como um acontecimento biográfico importante na trajetória de Hélida. Eloisa fez licenciatura em história, no final da década de 1970, mas para ela foi uma decepção, pela excessiva ênfase economicista e marxista; ela não reconhece contribuiçóes do curso para sua prática docente, mas sim para um amadurecimento pessoal, 
bem como para o desenvolvimento de maior liberdade para falar em público. $\mathrm{Na}$ trajetória de Simone, Rute e Hélida, vemos que a graduação em pedagogia foi um momento significativo de formação, de reflexão sobre a prática, de construção de saberes. Simone destaca o desejo de querer ler, pesquisar, buscar novas bibliografias; Rute viveu um intenso processo de reflexão, pois, ao mesmo tempo que cursava a graduação, vivia intensas angústias e questionamentos em sua prática docente; e Hélida fala também de um importante tempo de crescimento, de revisão de conceitos.

A graduação trouxe, por um lado, para Rute e Hélida, como contribuição comum, uma visão mais ampla e política sobre o processo educativo:

E isso é a faculdade que me esclareceu bem, essa visão. A parte mais pedagógica, manual o normal deu uma base didática [...], agora, a faculdade mexeu comigo em me abrir a minha a mente e entender o papel político do professor, isso ficou bem marcado [...], a não neutralidade do professor. [...] Não há professor neutro, ele não está ali só para ensinar conteúdo, você tem uma responsabilidade de transformação [...] Agora, eu só comecei a ter essa postura depois daqui, porque eu ainda tinha aquela coisa de professorinha (Rute).

[...] Eu era muito inocente, eu descobri na faculdade a minha inocência, por exemplo, antes de entrar na faculdade eu acreditava na neutralidade, eu acreditava piamente nisso, aprendi. Isso eu trago como formação da graduação sim, essa questão de ter enxergado o mundo de um jeito que eu nunca tinha visto antes. Eu era muito, muito engajada, mas eu não [...], eu era boba, eu acabava que ficava meio como joguete, porque eu não enxergava determinadas coisas. O meu olhar sobre a sociedade mudou a partir da faculdade, com certeza, com certeza (Hélida).

Por outro lado, as dinâmicas vivenciadas nas diferentes disciplinas proporcionaram o questionamento de práticas e de saberes. Rute fala que, inicialmente, "não entendia" como trabalhar o processo de alfabetização por meio de textos, mas foi tentando, experimentando e, aos poucos, encontrando resultados que a levaram a avançar. Nas aulas de matemática, ficou encantada com novas possibilidades de trabalho apresentadas pela professora: "E eu gostei muito, porque ela trouxe como ensinar a matemática. Você faz jogos ou material de cuisenaire, o material dourado, então, eu ficava doida para 
querer usar, para poder usar aquilo, fazer. E eu fiz em casa o meu material dourado com 'E-V-A', um emborrachado”. Já Hélida lembra a oportunidade de revisão de conceitos:

[...] porque eu ensinei para os meus alunos que existia um reino mineral que eu fui descobrir na faculdade que não existia. É cor, a cor vermelho ser cor primária, eu fui descobrir também na faculdade que vermelho não era cor primária. Aí eu falei: só tem um jeito, eu tenho que chamar eles todos de volta para corrigir as bobagens (risos) [...].

No relato das três professoras brasileiras que fizeram a graduação em pedagogia no final dos anos 1990 e início de 2000, assim como no das professoras portuguesas, a formação acadêmica colocou-se como espaço-tempo fundamental de formação em partilha com professores e colegas - um tempo de reflexão, revisão, consolidação de saberes, compondo um dos importantes acontecimentos de formação contínua, considerando que todas elas já se encontravam em pleno exercício da profissão.

A participação em cursos e eventos de formação contínua, como dissemos, encontra-se presente na trajetória de todas as professoras. Não observamos neles, entretanto, grande força e intensidade narrativa, ou seja, num olhar amplo tanto entre as professoras portuguesas como brasileiras, não foram colocados como pontos de viragem do processo de formação. O relato sobre essa dimensão da formação veio, de maneira geral, pelo questionamento da investigadora, e não pelo fluxo natural da narrativa.

Entre as professoras portuguesas, observamos referência a dois momentos específicos de organização do sistema educativo: quando as ações de formação constituíam iniciativas isoladas das escolas ou de grupos e quando passaram a constituir critério para a progressão na carreira. Nesses dois momentos, sinalizam de forma recorrente que sempre buscaram açóes sobre as quais tivessem de fato interesse, e não apenas pela necessidade de mudança de escalão, um interesse diretamente mediado por questões que pulsavam em suas salas de aula. Nesse sentido, as açôes de formação ocupam o lugar de atualização a respeito de temáticas e questôes específicas que surgem no cotidiano do trabalho docente com os alunos. Também sobre a importância da formação contínua, Isabel trouxe em sua narrativa uma reflexão sobre a não possibilidade de receitas, mas a oportunidade de partilha, encontro e troca de conheci- 
mento entre os colegas: "Muito importante, muito. É como eu te digo, havia muitas colegas que diziam, 'Ah, uma pessoa vem, não aprende nada', porque querem receitas e não há receitas na educação”.

Mas se as narrativas, em geral, sinalizam uma importância que não se destaca, encontramos, na trajetória de Ana, um processo de formação contínua que assumiu sentido de acontecimento biográfico de formação, mobilizando um processo fértil de reflexão-ação instituinte sobre a prática educativa. Ao longo de sua atuação profissional, nutriu um sentimento de inquietude, um "não estar bem instalada", o desejo por outros caminhos. $\mathrm{Na}$ mudança para uma nova escola, encontrou um grupo que se reunia de forma sistemática: o Círculo de Estudos para uma Pedagogia Diferenciada, em que partilhou a reconstrução de sua prática pedagógica, envolvendo toda a dinâmica do processo de ensino-aprendizagem numa formação contínua desenvolvida no contexto escolar. Em seu curso de Complementação, retomou essa experiência como tema de sua monografia, numa oportunidade de consolidação dos saberes construídos: "O meu último trabalho, a minha monografia, é exactamente o impacto, o impacto que teve em mim e nas pessoas que trabalharam no Círculo de Estudos para uma Pedagogia Diferenciada. Eu tenho isso escrito".

Voltando o olhar para o contexto brasileiro, vemos que os sistemas de ensino estaduais e municipais desenvolvem diferentes formas de registro dos processos de formação contínua, que, de forma geral, são oferecidos e incentivados, mas não necessariamente como requisitos de progressão na carreira. $\mathrm{Na}$ narrativa das professoras, encontramos diferentes perspectivas de análise a respeito da participação em eventos e cursos. Marta e Rosangela, professoras que atuam no interior do estado, a primeira já aposentada e a segunda em etapa final de carreira, referem-se à realização de cursos que contribuíram para a atualização específica de alguns temas. Nas palavras de Rosangela, esses eventos representam a busca de estar se atualizando e de não "permanecer na mesmice". Já Eloisa, professora do município do Rio de Janeiro, aposentada em uma matrícula, mas ainda em atividade na segunda, traz uma reflexão crítica; em sua análise, restringem-se a um "blá-blá-blá" e ao "estudo de autores da moda”. Rute, ainda nos primeiros anos de profissão, relata sem grande entusiasmo um encontro promovido pela Secretaria de Educação, destacando que foi bom, mas que muitas coisas ela 
já tinha estudado na graduação, e a contribuição se restringe à possibilidade de ouvir outros pontos de vista.

Nas narrativas de Simone e Hélida, observamos outro movimento. Simone sempre buscou, por iniciativa própria, fazer diferentes cursos e fala com vigor sobre alguns deles. Quando mudou de sua cidade natal para o Rio, ficou feliz com as novas oportunidades de formação que foram abertas. "Olha, participei de um de alfabetização. A Secretaria fez um próprio material de alfabetização e a gente tinha cursos [...], acho que semanalmente [...] E esse valeu muito, assim, porque era de troca".

Hélida tem memória de eventos de formação contínua, antes mesmo de ser professora, pois acompanhava as atividades de sua mãe. Sua vivacidade e desejo de saber encaminharam-na a um movimento intenso ao longo de toda a trajetória profissional; depois da conclusão do Curso Normal, sempre buscou todas as formas de participar dos mais variados cursos. Foi construindo um caminho de estudo que, como vimos anteriormente, fazia as pessoas pensarem que já era graduada e que encontrava ressonância em sua prática: estudos sobre Paulo Freire, Emília Ferreiro e diversas áreas de conhecimento. No movimento de aprofundamento e de reflexão sobre a prática pedagógica, Simone e Hélida ingressaram em um curso de pós-graduação voltado à alfabetização. Simone buscava respostas para a dificuldade de aprendizagem de alguns alunos. Foi para o curso com a sede de quem busca respostas, desenvolveu sua monografia sobre o processo de aprendizagem e considera que foi um momento importante de afirmação profissional, ao se colocar como professora:

[...] E com muita crise no meu trabalho, muita, [...] de achar que eu não estava sabendo ensinar. Eu liguei pra uma professora, pedi uma ajuda, uma ajuda enquanto alfabetizadora [...] 'Eu tô em crise, tô querendo desistir do magistério, eu tô sentindo que eu não tô dando conta'. Aí ela sugeriu que eu fizesse de novo a prova, que eu tentasse de novo a pós. Ela falou: 'Olha, vai abrir a pós, não sei o quê”. Aí tentei mais uma vez [...] Ajudou muita coisa. Ajudou, mais segurança pra mim, a você pesquisar enquanto[...] pesquisar mais, buscar mais, não se acomodar naquele [...], eu fiz tudo.

Hélida concluiu a graduação e ingressou direto na pós, um curso que também constituiu um marco em sua formação, especialmente quanto à ela- 
boração de sua monografia. Chegou com um tema definido, mas ao longo do processo foi reconstruindo sua perspectiva sobre a pesquisa, e o texto monográfico assumiu a forma de crônicas reflexivas sobre sua trajetória docente. É interessante destacar que a escrita do trabalho monográfico aparece na trajetória de três professoras como verdadeiros acontecimentos biográficos de formação: Ana, professora portuguesa, escreve sua monografia de conclusão da licenciatura como reflexão e pesquisa a respeito do círculo de estudos de que participou; Simone toma sua própria prática de professora alfabetizadora e a dificuldade de alguns alunos como foco de estudo; e Hélida retoma episódios marcantes de sua trajetória docente como campo de reflexão sobre as relações de poder na escola. A escrita monográfica aparece como um espaço-tempo de formação contínua, como oportunidade de retomar reflexivamente a própria trajetória de vida, formação e profissão como campo de pesquisa. $\mathrm{Na}$ vida dessas professoras, encontramos sentidos para a docência como exercício critico e reflexivo permanente de formação.

\section{Memórias das experiências profissionais}

Se começamos, ainda na infância, a constituição de imagens e referências sobre a docência, se os cursos acadêmicos que visam à profissionalização inicial dos professores também exercem um lugar especial nesse movimento, muitos estudos têm afirmado a centralidade do percurso profissional na construção de diversos saberes e na formação docente. Ouvindo as histórias das professoras, lendo suas biografias educativas, encontramos em diferentes momentos a entrada na escola como acontecimento biográfico não só de formação, mas da vida: na infância e na juventude, a experiência como alunas e, na vida adulta, o retorno a esse mesmo e conhecido espaço no papel de profissionais docentes instaurou, também, para todas elas, um divisor de ciclos existenciais. A trajetória docente se afirma, em seu desenrolar, como espaço-tempo privilegiado de mobilização e confronto, construção/reconstrução de saberes. Os que trabalham com formação inicial e contínua de professores ouvem, de forma insistente, que as discussões acadêmicas não são suficientes na "preparação" para a prática profissional. Concordamos com isso e, ainda, que não poderão mesmo ser suficientes, pois a tessitura da formação docente não se coloca na beleza de um retalho, mas na composição da colcha, uma composição complexa que articula dimensóes pessoais, acadêmicas e profis- 
sionais. O exercício da profissão mobiliza valores construídos ao longo da vida e desafia as reflexões-ações desenvolvidas ao longo da formação inicial e, nesse confronto, gera novas aprendizagens, formação e sempre novas formas de ser e de estar na vida e na docência.

A trajetória profissional docente é, assim, terreno fértil de formação. Ao olhar atentamente as histórias das professoras, perspectivamos acontecimentos biográficos de formação que se repetem, que dialogam entre si, e outros que se singularizam; neste momento do texto, perseguimos esses movimentos e procuramos aprender com eles. Tanto Huberman (1992) quanto Gonçalves (1992), que fazem estudos específicos dos ciclos de desenvolvimento docente, destacam a importância do início da carreira. Ao falar sobre a entrada na profissão, as professoras participantes - em que percebemos mais o sentimento de "descoberta" do que de "sobrevivência"11 - narraram esse momento pelo sentido de realização pessoal, de autonomização: ter uma turma, exercer a profissão que escolheram; entretanto, o sentido de sobrevivência manifesta-se na angústia do confronto entre a prática idealizada e a materialidade do dia a dia, no sentimento de isolamento, no questionamento de seus saberes. Um tempo importante de formação, pois instaura o questionamento crítico, a dúvida; saberes anteriormente sistematizados, especialmente nos cursos de formação inicial, são postos em questão. Interessante que algumas falam dos primeiros anos de forma muito tranquila, e o "choque com a realidade" vem anos depois, ${ }^{12}$ quando enfrentam práticas educativas que as desafiam a avançar; outras vivem esse momento logo no primeiro ano de exercício da docência. ${ }^{13}$ Mas para elas

11 "O aspecto da 'sobrevivência' traduz o que chamamos vulgarmente de 'choque do real', a confrontação inicial com a complexidade da situação profissional: o tactear constante, a preocupação consigo próprio ('Estou-me a aguentar?'), a distância entre os ideais e as realidades cotidianas da sala de aula, a fragmentação do trabalho, a dificuldade de fazer face, simultaneamente, à relação pedagógica e à transmissão de conhecimentos, a oscilação entre relações demasiado íntimas e demasiado distantes, dificuldades com alunos que criam problemas, com material didáctico inadequado etc. Em contrapartida, o aspecto da 'descoberta' traduz o entusiasmo inicial, a experimentação, a exaltação por estar, finalmente, em situação de responsabilidade (ter sua sala de aula, seus alunos, seu programa), por se sentir colega num determinado corpo profissional)" (Huberman, 1992, p. 39).

${ }^{12}$ Como observamos na biografia educativa das professoras Clara, Hélida, Rute e Simone.

${ }^{13}$ Como percebemos na biografia educativa das professoras Ana, Teresa, Bela, Eloisa, Marta e Rosangela. 
esse é um tempo de experimentação, descoberta e enfrentamento, intensamente fértil.

Nos anos iniciais, e em diferentes momentos da trajetória docente, encontramos uma recorrência: a presença de colegas professoras que assumiram o papel de "formadoras", colegas mestras, amigas com quem partilharam anguistias e dividiram alegrias e desafios da prática docente. Ana fala de colegas formadoras que foram mestras e a impulsionaram a avançar: no início da carreira, Rute, uma professora leiga, com grande saber da experiência, partilhou as angústias iniciais, incentivou a realização de concurso para a rede oficial; Madalena esteve presente num momento de reconstrução importante de suas concepçōes e práticas; Rose e Clara, nas aprendizagens da gestão escolar. Teresa fala das dificuldades do momento inicial da docência, mas lembra a presença de colegas que a ajudaram a refletir, indicando diferentes possibilidades para o caminhar; Bela recorda os tempos iniciais de trabalho na escola anexa, quando era uma jovem professora e encontrou colegas que foram, para ela, "mestras espectaculares"; quando Clara ingressou em uma escola que apresentava uma prática pedagógica ancorada em uma concepção-ação educativa diferente de sua experiência de aluna e das aprendizagens que levou da formação inicial, teve, em Isabel, uma referência na prática educativa, no ensino da leitura e da escrita, na relação com os miúdos. As professoras brasileiras também citam colegas mestras: Hélida teve a ajuda de sua mãe professora; Rosangela iniciou a atuação profissional sob a orientação de Marta, que foi sua professora no primário e no ginásio e acompanhou o início de seu trabalho como professora.

Nessas experiências, a escola apresenta-se como um lugar de encontro e amizade que, potencialmente, pode gerar intensas redes de conhecimento e partilha. A mudança de escola, para algumas professoras, consistiu em acontecimento biográfico de formação. Ana e Isabel encontravam-se inquietas, desejavam a reconstrução de suas práticas e encontraram, em novo contexto escolar, incentivo, apoio e referências de formação:

[...] Porque lá está a mudança que eu há pouco falava, eu já tinha uns anos de trabalho com um método que não era este, eu queria aproximar-me deste, eu fazia sempre aquilo que entendia, o melhor que podia, mas eu não me sentia muito bem instalada, eu tinha necessidade de fazer outras coisas, de dar 
mais aos meus alunos. E a minha vinda para esta escola foi realmente fundamental para o meu percurso profissional, porque as escolas grandes têm esta vantagem, somos muitos, portanto, há pronto, há naturalmente pessoas mais abertas como em qualquer profissão, outras menos, mas é assim, há sempre uma possibilidade de uma maior riqueza, duma maior partilha, duma troca de saberes e de técnicas e de [...] (Ana) .

$\mathrm{E}$ eu, quando isso começou, era um bichinho que me estava a pôr muito insegura no meu papel como professora, comecei a tomar consciência, como eu já disse, qual era o meu papel, qual era o meu dever perante aquela turma, perante aqueles meninos [...] O que é que eu comecei a fazer? A distância não era muita, eu comecei, no fim do meu dia de trabalho, eu comecei a vir cheirar isto. Já não tinha meninos aqui, mas tinham colegas que ficavam e que falavam sobre todos os meninos, se havia um menino, um problema com um menino, todos os colegas estavam preocupados com esse menino. E, então, o ter inveja é muito feio, mas eu comecei a ter inveja destes colegas daqui, onde todos se preocupavam com todos, onde todos conheciam e comecei a vir mais vezes, mais vezes, mais vezes, comecei a levar ideias de cá para lá, comecei a tentar implementar, com muitas dificuldades, porque eu era só na turma, só eram aqueles meus meninos, eu levava para os meus meninos (Isabel).

Posteriormente, Isabel recebeu um convite e foi trabalhar nessa escola, aprendendo com os colegas a reinventar sua prática como orientadora educativa. Na trajetória de Teresa, Bela e Clara, diferentes experiências também nos levam a observar a centralidade da escola como contexto formador. Na crítica à monodocência, Teresa relata a experiência de um trabalho partilhado por diferentes colegas, em que cada um desenvolvia atividades diferenciadas com as turmas; Bela trabalhou em uma escola anexa ao Curso do Magistério Primário, no qual havia reuniōes periódicas entre os professores do Magistério e os da escola, favorecendo um processo importante de aprendizagem; Clara, depois de um tempo sem emprego, foi trabalhar na mesma escola na qual estava Isabel e lá encontrou apoio para reinventar suas concepções e práticas sobre o fazer educativo.

Com a mesma intensidade, as professoras brasileiras narram também sobre escolas por quais passaram e que instauraram novos e instituintes ciclos de formação. Eloisa refere-se a uma das escolas em que trabalhou como lócus 
importante de sua formação pelo ambiente entre as colegas e a diretora, que era excelente, e pelo trabalho em equipe: "Todos se conheciam, então, era como se fosse um jogo de futebol, uma alfabetizava e passava para a outra, que completava a alfabetização, que já passava para a outra, que fazia determinada coisa, passava [...]". Simone refere-se às primeiras escolas em que trabalhou destacando o apoio que recebia quanto aos materiais didáticos e no processo contínuo de formação. Na trajetória de Rosângela, a mudança para um instituto que atende crianças carentes vem como marco significativo; inicialmente, deparou-se com dificuldades na relação com os alunos, mas aos poucos foi desenvolvendo seu trabalho, chamando outras colegas que passaram a trabalhar juntas; a narrativa de seus últimos anos no magistério confunde-se com a narrativa da história da escola. Hélida traz a aprendizagem que vem pelo confronto, pois em um momento de grande envolvimento com uma instituição escolar foi levada a se desligar, saiu de um ambiente próximo, conhecido, "uma escola que amava", para um ambiente adverso, marcado por uma gestão autoritária, mas ela e suas colegas não se acomodaram, insistiram e, nessa insistência, partilharam e aprenderam.

$\mathrm{Na}$ narrativa das professoras, por um lado, encontramos a centralidade da escola como campo fundamental de formação, no qual suas histórias se entrelaçam com a história das escolas; por outro, observamos falas que destacam, justamente, a dificuldade de encontro entre as professoras, afirmando-se como lugar de isolamento. Nesse sentido, Isabel analisa criticamente a monodocência, pela interdição da partilha, pelo isolamento, quando o perguntar torna-se sinônimo de fraqueza.

Comecei a sentir-me muito egoísta, inconscientemente a pessoa começa a perceber que é muito egoísta em relação aos outros colegas, porque basta um simples recreio, um vidro partido, a pessoa põe a cabeça de fora da janela e dizia 'Não foi o meu aluno que partiu o vidro, portanto, não é nada comigo' [...] Porque, quando está só, a monodocência leva-nos para esses caminhos, porque não partilha nada com o outro, porque não recebe nada do outro, é um mundo à parte. Se há quatro salas, há quatro mundos diferentes, e a educação não pode passar por aí. A educação, eu tinha o dever, eu tinha o dever de ajudar a colega do lado em determinados momentos, quando o vidro foi partido, mas não, eu retraía-me; se estava sentada a tomar um chá ou um café, 
eu ficava e é isso que se sente nas escolas em que cada um tem a sua turma, em que cada um tem o seu buraquinho, percebe? (Isabel)

Bela, que viveu intensos momentos de aprendizagem com colegas mais experientes no início da profissão, sente que, a cada dia, todos estão mais distantes:

[...] partilhávamos muito mais, éramos muito mais solidárias [...] Isso, se calhar, é próprio mesmo desta evolução da sociedade, na própria sociedade as pessoas vivem muito mais para si, vivem muito mais para os seus problemas. Acho que a escola era um bloco, funcionava mais em conjunto. Esses últimos anos, eu reparo que há menos partilha, menos solidariedade entre as pessoas, as pessoas são um bocado mais egoístas, fecham-se mais na sua sala, tenho notado isso [...] (Bela).

Em sua avaliação, a mobilidade dos professores também dificulta a partilha e a construção colectiva. Na história de Hélida, observamos uma experiência significativa de interdição do diálogo e da construção coletiva, mas também de resistência, quando uma diretora autoritária proibiu que as professoras se encontrassem, antes do início da aula, na sala dos professores, e elas, então, passaram a chegar mais cedo e a conversar no portão, do lado de fora da escola, e só entravam quando tocava o sinal. Em sua experiência como professora contratada, Rute não sentiu espaço para troca entre as colegas. Eloisa cita a dispersão que caracteriza a reunião de professores, o que não possibilita uma efetiva construção coletiva do planejamento. Marta, em sua experiência como professora, em uma vila do interior, fala da dificuldade de encontro entre os professores, pois a maioria morava na cidade e tinha de sair rapidamente da escola e pegar uma estrada que era de terra, e muitos ainda trabalhavam em outras escolas. Trajetória profissional docente e escola se encontram, pois esta, muito mais do que palco e cenário, é mobilizadora de intensas experiências de formação que se dão no confronto entre o encontro e o distanciamento, instituinte e instituido.

$\mathrm{Na}$ história de duas professoras, uma portuguesa e outra brasileira, confrontamo-nos com um acontecimento biográfico relacionado ao trabalho desenvolvido com uma turma em especial. Ana viveu um momento significativo e renovador com a mudança de escola, com a participação no Círculo 
de Estudos. Uma confluência de fatores constituiu um momento destacado por ela como representativo de grande mudança de sua práxis educativa, e dentre esses fatores ela ressalta a turma com a qual trabalhou durante os quatro anos do 1o ciclo: alunos envolvidos, interessados no processo de ensino-aprendizagem, que favoreceram a mudança gradativamente vivida por ela. Hélida, professora brasileira, fala de sua segunda turma de uma forma especial: o relacionamento com eles, o envolvimento, permitiu que vivessem juntos a construção de um trabalho que, por insistência dela, estendeu-se por três anos. ${ }^{14} \mathrm{Na}$ fala das demais professoras, encontramos também referência a turmas que marcaram e, de uma forma especial, ensinaram e favoreceram movimentos instituintes da formação. Foi recorrente em suas narrativas a lembrança de alunos que prosseguiram os estudos, que superaram situações muitas vezes difíceis e se afirmaram profissionalmente; nesses casos, a fala das professoras, de maneira geral indica um tom de realização. Por outro lado, as situações de abandono escolar ou de trajetórias não tão bem-sucedidas são lembradas com tristeza e decepção.

Com Freire (1992), afirmamos que professores/as e alunos/as ensinam e aprendem e observamos de forma marcante como, em suas histórias, o relacionamento com turmas e alunos, destacados muito especialmente, constituiu importantes momentos de formação na trajetória profissional. Nesse aspecto, tomamos a história de Rute como inspiradora, pois sua narrativa destaca em cada etapa, com cada turma, alunos/as que ensinaram, apresentaram a ela a dura realidade de vida do lixão, fizeram-na refletir sobre o relacionamento professor-aluno e disciplina e levaram-na a acompanhar processos de aprendizagem da leitura e da escrita, que, nela, se confrontaram com a construção de uma síntese pessoal entre as leituras e discussões acadêmicas de sua formação no curso de pedagogia e a vivência concreta da sala de aula.

A presença dos pais no processo de aprendizagem também é destacada pelas professoras. Carolina se lembra de atividades em que foram à escola para falar de seus campos de trabalho ou estudo e também da contribuição quanto ao acompanhamento das excursóes. Porém, esse foi um relato singular, pois, de maneira geral, as professoras se referiram a certa ausência da família, que elas percebem intensificar-se a cada novo ano escolar. Sentem, no dia a dia da sala de aula, uma nova configuração da sociedade e da família. As crianças

\footnotetext{
${ }^{14}$ No Brasil, as/os professores/as geralmente acompanham os alunos por, no máximo, dois anos.
} 
chegam à escola apresentando novas necessidades e posicionamentos frente ao processo educativo; os alunos e elas próprias não recebem o apoio que consideram necessário. A complexidade dos contextos socioculturais e suas mediaçoes com a prática educativa desafiam as professoras, contexto que as leva a refletir e a se posicionar. Teresa menciona a crise ética e social: "Os pais não têm tempo para os filhos, não dedicam cinco minutos para ver seus materiais, é escola e ATL. ${ }^{15}$ Faltam atenção, carinho, cuidado, acompanhamento". As demais professoras portuguesas também se referem a esse contexto de crise de valores. $\mathrm{O}$ relato das professoras brasileiras, que têm experiência de trabalho em regiōes de intensa exclusão social, traz as cores fortes e cinzentas: histórias de abandono, de envolvimento das crianças com o tráfico de drogas e de violência doméstica. Histórias familiares e do contexto social que se apresentam na escola e que as desafiam a reconstruir saberes e práticas. Nessas situaçōes e contextos, há um saber que vem como síntese de múltiplas experiências pessoais, acadêmicas e profissionais, um saber gerado na urgência, situaçôes imprevisíveis, que exigem respostas no aqui e agora, instituem momentos importantes de formação.

Três professoras portuguesas destacam a atuação como professoras cooperantes como acontecimentos biográficos de formação; a presença de estagiários em suas salas de aula, a orientação de seus trabalhos, a reflexão sobre a prática constituíram momentos significativos de aprendizagem profissional.

E era interessante, quando acabavam as aulas, às três e meia, lá está a turma no horário normal, três e meia da tarde os meninos iam-se embora. Nós ficávamos ali, sentados a conversar, eu gosto muito sempre de dizer como faço, o que que faço; as angústias, mas também as coisas boas e era muito isso que se fazia. Eles sentavam-se comigo e perguntavam, 'Mas fez assim, mas por que fez?', eu explicava, e eles davam também as suas opinióes, e era tão bonito (Ana).

$\mathrm{Eu}$, dos momentos que eu considero que mais envolvimento houve nesse tipo de formação, era o facto de ser professora cooperante de estagiárias, porque aí

${ }^{15}$ Atividades de tempos livres (ATL). Em Portugal, tanto as escolas públicas, por meio da associação de pais, como as entidades privadas oferecem atividades educativas complementares no horário inverso ao turno de estudo, ajudando as famílias que trabalham e precisam deixar os filhos durante todo o dia na escola. 
era como que um levá-las também a sentirem essa necessidade e, agora, vamos pesquisar e pesquisavam elas, pesquisava eu, desenvolvíamos projectos com os alunos, sempre no sentido, de, pronto, de se conseguir algum resultado e algum enriquecimento para os alunos (Carolina).

O facto de, na minha sala, terem estado sempre alunos estagiários, eu não era a mesma professora, sinto que não era, porque, com o aluno ali na sala, nós não podemos, mesmo que queiramos estagnar, não podemos, obriga-nos a [...] e aprendo tanto com eles, porque é aquela altura da vida em que há muitas ideias [...] Gosto imenso e penso que era um bocado diferente, se não tivesse tido sempre estagiários na minha sala (Bela).

Tempo de partilha, de troca, de construção. Assim como narraram aprendizagens significativas do período em que foram estagiárias, agora, como professoras cooperantes, contribuem para o processo de formação das futuras colegas e, ao mesmo tempo, refletem sobre sua prática, mobilizam-se na construção da praxis, formam-se. $O$ fato de não encontrarmos referências ao estágio na narrativa das professoras brasileiras leva-nos à reflexão e ao questionamento: por que na trajetória das seis professoras não há referência significativa ao momento de estágio, nem a presença de estagiários em suas salas de aula? Tanto a ausência na narrativa das professoras como a vivência em contextos de formação, no Brasil, levam-nos a levantar vestígios de que esse movimento não esteja se dando de forma suficientemente sistemática e reflexiva, passando por questóes de organização curricular e, especialmente, de articulação entre as instituições formadoras e as escolas básicas.

Do que observamos até o momento, vemos, na vida das professoras, o desenvolvimento da trajetória profissional como percurso formador e, em seus relatos, aparece outra recorrência: a diversidade de atividades profissionais na docência como uma contribuição relevante para o processo de formação. Atuação no ensino especial, no apoio a alunos com dificuldades especiais, em turmas de diferentes contextos socioculturais, em atividades diversificadas na escola, passando pela gestão, pela coordenação, pelo desenvolvimento de atividades culturais. A diversidade desafia e ensina a necessária e permanente reinvenção da profissão.

A tessitura cotidiana da docência mobiliza um processo de autoformação. Ao longo das narrativas, encontramos referência a momentos de inquietação, 
de busca de reconstrução das formas de ser e de estar na docência quanto à dinâmica das relações entre escola, alunos, colegas e famílias. Observamos ainda que contextos sócio-histórico-culturais, conteúdos e currículos geram dúvidas/desafios, e os saberes construídos são colocados em questão, levando as professoras ao movimento, o qual assume diferentes direçóes e ancora-se em diferentes princípios.

Em alguns relatos, encontramos a formação pessoal e as imagens da prática pedagógica de suas antigas professoras como balizadores do que desejam como imagem de si e da prática educativa; assim, observamos que desafios postos, aprendizagens e avanços dialogam com uma referência de prática docente anteriormente construída.

Em outras trajetórias, percebemos uma inquietação que leva à busca de algo que ainda não viram, não conhecem, mas desejam intensamente; desejo que mobiliza a procura, que institui novos ciclos de formação. Foi assim que Ana nutriu, ao longo de sua carreira, um profundo sentimento de inconformidade com sua prática e decidiu mudar de escola à procura de Madalena, que já desenvolvia um processo instituinte de leitura e escrita, que construía livros com seus alunos. Foi assim que Isabel começou, a pouco e pouco, a partir de notícias que uma colega lhe dava a respeito do trabalho de outra escola e de um grupo de professores/as, a introduzir novas dinâmicas com seus alunos, a movimentar-se até essa outra escola, para sentir, cheirar, aproximar-se. Foi assim que também decidiu mudar de escola, possibilitando a abertura de novos caminhos. Foi também em uma busca permanente de reconstrução que Hélida se envolveu com cada uma de suas turmas, que buscou avidamente encontros de formação contínua e, depois, encontrou na graduação e na pós-graduação outras fontes de reflexão. Foi assim que Simone, ao receber um pacote alfabetizador vindo da direção da escola, contrapôs-se, pois aprendeu com a tia professora e no curso de pós a contra-argumentar e a buscar com cada uma de suas turmas de alfabetização um novo e instigante caminho de leitura e escrita. Rute, tomando referência em práticas de ensino-aprendizagem que vivenciara como aluna, e por seu forte desejo e envolvimento com a docência, foi aos poucos refletindo e incorporando as contribuições acadêmicas na mediação com os difíceis contextos por que tem passado. Nesse processo de autoformação em contexto, Ana e Hélida refletem em partilha e escrevem, registram movimentos, avanços e recuos. Ao longo da vida, em alguns momentos mais intensos e em outros menos, as 
professoras escrevem e publicam, socializam o processo de construção da docência e da formação.

A docência em ação, em relação, em mediação é espaço-tempo de aprendizagem, é construção cotidiana que mobiliza angústias, dores, sofrimentos, mas também alegrias, sentimento de gratificação. Nas narrativas, encontramos ora uns, ora outros, mas, sobretudo, uns e outros, juntos, constituindo sentidos da vida, como luta, como movimento dialético e humanamente experienciados.

\section{Reflexões}

Neste momento de reflexão, retomamos, em perspectiva, o entrelaçamento entre diferentes dimensões formadoras tecidas ao longo da história de vida das professoras participantes: experiências e vivências costuram a "tessitura da intriga" do processo formador, que se diz de forma singular e plural. $\mathrm{Na}$ narrativa das professoras, quais foram os principais acontecimentos instituintes de formação? Como eles se configuram, em diálogo, nas diferentes trajetórias? O que nos ensinam sobre a tessitura do processo formador?

Observamos que a pesquisa educacional e, consequentemente, a literatura sobre formação docente têm colocado grande peso na dimensão acadêmica da formação, nomeadamente na formação inicial e contínua, bem como nos processos que se dão no cotidiano da profissão e favorecem a reflexão sobre a prática e os movimentos de autoformação. A trajetória de vida das professoras participantes da presente investigação aponta, contudo, a centralidade de dimensões que ainda carecem de aprofundamento, como a formação pessoal, marcada por influências familiares e contextuais, e a experiência escolar anterior aos cursos formais de preparação profissional para a docência, ou seja, as vivências na "escola primária" e nos ciclos seguintes de escolarização.

Tomando como perspectiva o sentido da vida como espaço-tempo de formação, observamos que a constituição de imagens e referências sobre a docência e sobre a prática educativa não se concentra em um momento privilegiado, mas se espraia e se entretece, articulando a dimensão pessoal, tecida junto ao núcleo familiar e no contexto das relações sócio-histórico-culturais, e a dimensão acadêmica, que marca sua forte presença desde as primeiras experiências escolares e passa pelos caminhos formais de profissionalização 
da docência e pela formação contínua e a trajetória profissional, que, por sua natureza, mobiliza e reconstrói saberes, gerando sempre novas formas de ser e de estar.

A análise dialógica entre as trajetórias que procuramos construir neste capítulo dá visibilidade a esse movimento complexo, em que cada experiência, como fragmento, indica sentidos e leituras que se tornam inteligíveis na composição da "intriga". Os polifônicos sentidos da formação, na trajetória de vida das professoras, não se expressam, assim, pela particularidade da análise de cada uma das referidas dimensões ou "retalhos", mas nos indícios da tensa articulação entre elas. Por esse caminho, vamos encontrando pistas da formação docente como "tessitura da intriga", histórias que se entretecem na memória e se refazem no processo narrativo, indicando a poesia da vida humana em sua abertura a sempre novos e, potencialmente, instituintes projetos de futuro. 


\section{Reflexões (in)conclusivas: a formação como tessitura de intrigas}

Hoje terminei as biografias educativas das 12 professoras - um momento de felicidade. A cada dia, me sinto terminando a tese, estou vivendo o 'luto' e a 'celebração': luto, por um estranho sentimento de saudade da tese, desse tempo de trabalho; mas celebração pela alegria de ver a pesquisa andando, quase pronta ... (23 set. 2007).

Nunca demorei tanto para escrever uma página, algo me bloqueava; um desejo contraditório de não querer concluir o último capítulo? Ou medo de não dizer o suficiente, o necessário? Estava tomada de melancolia quando parei o que estava escrevendo e comecei a fazer os agradecimentos, um desejo de agradecer a Deus e começando por Ele vieram a família, os amigos, tantas pessoas sem as quais não teria percorrido esse caminho. À força a terminei, fechei o computador quando já estava exausta fisicamente. Depois da noite, hoje sinto novo fôlego. $\mathrm{Na}$ demorada escrita de ontem, encontrei lampejos importantes que podem me ajudar na conclusão (21 out. 2007).

Neste momento singular de nosso trabalho, olhamos para trás e buscamos sentidos da pesquisa realizada, vivemos a intensidade da construção do conhecimento científico que se dá em permanente devir histórico e como aventura partilhada, dialógica. Se a origem da pesquisa não se coloca na formalização do início do doutoramento, mas no tempo do desejo, também as conclusões são (in)conclusivas, confrontam-nos com a precariedade e a provisioriedade do saber humano, que se traduzem em movimento imanente de devir. Tomando 
como referência o paradigma indiciário (Ginzburg, 1989), propomos reflexões que indicam pistas, indicíos e sinais a respeito da problemática anunciada e dos questionamentos feitos inicialmente, que se desdobraram em tantos outros ao longo do caminho. Em um movimento de volta, de retorno do pensamento "sobre si mesmo", ${ }^{1}$ buscamos, aqui, um olhar para a trajetória da pesquisa e para os lampejos que dela faíscam, tentando apreender indicativos a respeito das questôes iniciais propostas, mas também, e especialmente, procurando apreender a transformação dessas próprias questôes ao longo da investigação.

Esse olhar para a investigação-formação nos leva ao encontro de sentidos da pesquisa como aventura partilhada e dialógica entre a investigadora e as professoras-participantes-investigadoras-formadoras. Nesse sentido, as reflexões (in)conclusivas, que trazem a dialética pessoal-coletiva, são escritas pela investigadora "proponente", mas buscarão apoio nas vozes e nos sotaques das professoras envolvidas. Portanto, continuamos querendo ouvir suas vozes, encontrando nelas e no diálogo a centralidade das contribuições da pesquisa. No momento em que buscamos "reflexões" a respeito dos sentidos que, "a pouco e pouco", foram se delineando na tessitura da pesquisa, é importante exercitar, mais uma vez, a escuta atenta e silenciosa, buscando perceber a melodia polifônica que vem dessa experiência. Vivemos juntas uma longa travessia, viajamos por diversos continentes, rompemos o tempo e a cronologia de nossa própria existência e reconstruímos histórias que nos levaram a diversas paragens, desde o início do século XX até os dias atuais, em um intenso movimento de ir e vir. Partilhamos histórias de rir e de chorar, histórias quentes, algumas frias, muito antigas, muito recentes, histórias de mulheres, de professoras. Desse modo, a experiência da pesquisa como partilha e diálogo foi adensando ainda mais sua permanente reconstrução e seu devir.

Iniciamos o trabalho mobilizados pelas seguintes questões: o trabalho com as histórias de vida, em contexto de formação de professores/as, pode contribuir na busca de uma racionalidade mais humana, sensível e partilhada? Qual o sentido da rememoração no processo permanente de formação, de construção de saberes, de reconstrução dos projetos de futuro pessoais e coletivos sobre a vida e a profissão? A experiência narrativa pode tornar mais visível e, ainda, potencializar as diversas dimensões da trajetória de vida e formação dos

1 Reflexão, do latim, reflexione, "ação de voltar para trás, de virar", "volta da consciência, do espírito, sobre si mesmo, para examinar o seu próprio conteúdo por meio do entendimento, da razão" (Ferreira, 1999). 
professores/as, nomeadamente o entrelaçamento entre memória, experiências docentes e formação acadêmica? Quais as potencialidades das biografias educativas, em contextos de formação, como caminho de elaboração pessoal/coletiva do testamento da docência e de sua afirmação como "lugar de memória"?

Em sua multiplicidade, encontramos três grandes eixos propostos pela investigação: 1) história de vida e formação - contribuições: busca de uma racionalidade sensivel; 2) diversas dimensões da trajetória de vida e formação dos/as professores/as; e 3) expressão da vida e do "testamento" da docência pelos sujeitos da profissão. O desenvolvimento do trabalho trouxe, entretanto, um eixo que se foi afirmando e se colocando como articulador dos demais: o sentido dialógico da investigação e da formação. $O$ fato de a pesquisa ter sido sonhada no Brasil, iniciada em Portugal, vivida lá e cá, efetivamente, e o envolvimento de professoras desses dois países e de diferentes cidades potencializaram um diálogo fértil sobre a formação docente.

Procuramos, então, desenvolver essas "reflexôes (in) conclusivas", voltando aos lampejos de cada um desses referidos eixos/questóes e ao caminho de confluência entre eles, buscando sentidos a respeito do movimento formador. O primeiro é o mais amplo e fala da possibilidade do encontro entre história de vida e formação na constituição de uma racionalidade sensivel, instituinte no campo da formação. As questões iniciais do projeto de investigação já sinalizavam, e observamos realmente que o desenrolar da pesquisa fortaleceu a perspectiva de que a metodologia utilizada não consistiu em um meio para o alcance dos objetivos propostos, mas sim em um dos focos privilegiados de análise. Assim, o trabalho com as histórias de vida das professoras como abordagem metodológica não visou apenas ao encontro de pistas e indicativos sobre a natureza do processo formador ao longo da vida, mas à possibilidade de perceber em que medida a vivência da experiência narrativa, por meio da dinâmica metodológica proposta, poderia favorecer, ela própria, um caminho instituinte de formação para todos os envolvidos, incluindo professoras e investigadora.

Trazendo o sentido da formação como "experiência do sujeito que se permite transformar pelo conhecimento", ${ }^{2}$ o desenvolvimento do trabalho nos leva a levantar indícios de que essa experiência se dá de forma privilegiada no processo narrativo e, considerando a natureza da pesquisa, questionamos: qual o impacto da participação, nesse processo de investigação, pelas professoras, em suas

2 Desenvolvemos essa análise nos capítulos 2 e 3. 
trajetórias de vida e formação? Essa questão talvez possa constituir tema de outro trabalho que anos depois venha recolher outras histórias das mesmas professoras, e, então, com o passar do tempo, talvez seja possível avaliar com maior propriedade a intensidade formativa da experiência que vivemos. Entretanto, mesmo na precariedade, mas também na força e na vivacidade do presente, podemos levantar vestígios, trançando especialmente os depoimentos do terceiro encontro com os textos escritos a posteriori pelas professoras.

Considerando a proposta de investigação-formação que envolve a pesquisa, inserimos na metodologia dois componentes de avaliação, buscando oportunizar um momento oral, partilhado com a investigadora, e outro escrito, de natureza individual, em que as professoras puderam se expressar criticamente sobre o sentido e o lugar da participação na investigação em sua trajetória. Se a proposta do nosso estudo foi construir uma experiência narrativa com o passado, resgatando experiências formadoras construídas ao longo da vida em sua multiplicidade de tempo e espaço, a avaliação proposta desafiou as professoras na análise dos sentidos da própria investigação, nesse contexto de vida e formação.

Assim, no final do terceiro encontro, propusemos os seguintes tópicos de reflexão: como você avalia os encontros desenvolvidos no processo da pesquisa-formação, do ponto de vista da metodologia, dos eixos e questóes? Destaque aspectos positivos e negativos. Que avaliação poderia desenvolver sobre o sentido de sua participação nesse processo em sua trajetória de vida e profissão?

Para a reflexão escrita, sugerimos: 1) a avaliação dos encontros desenvolvidos no processo de pesquisa-formação, destacando aspectos positivos e negativos; 2) sentido/contribuição do movimento de narrativa e rememoração em sua trajetória; e 3) análise do significado da partilha da vida, em seus movimentos formadores, entrelaçando memórias pessoais, formação acadêmica e experiências profissionais. Partimos, então, da análise das transcrições do terceiro encontro e do material enviado posteriormente por escrito.

As professoras se identificaram com a metodologia proposta. Algumas mencionaram que viveram, inicialmente, ansiedade e inquietação, mas esses sentimentos foram vencidos ao longo da travessia-narrativa e na relação estabelecida com a investigadora. ${ }^{3}$ Ressaltaram, especialmente, que o clima

3 Como aspectos negativos, uma das professoras registrou a dificuldade de manter o fluxo narrativo, em virtude da gravação, e outra, "o facto dos nossos encontros terem acontecido em horário pós-laboral, o que de certa forma prejudicou a nossa dinâmica, motivada pelo cansaço”. 
informal, de encontro e partilha, levou-as a se sentirem muito à vontade para a narrativa, sem barreiras ou impedimentos: "Não senti que estava a ser entrevistada nem estava minimamente preocupada com o que tinha que dizer. A minha participação foi sincera e muito espontânea" ‘ (Clara). "Porque eu também me abri muito consigo, eu, sem perceber estava a falar consigo das coisas, $[\ldots]$ porque se estivéssemos aqui, se calhar, com muitos formalismos, com muitas [...], pensar só no que havia de dizer e tudo muito [...], acho que não tinha fluído assim como foi” (Bela).

A avaliação oral revela que as professoras foram envolvidas pelo prazer da reconstrução narrativa de si:

Eu acho que as palavras são como as cerejas, são mesmo, uma pessoa está aqui, salta para ali [...] foi uma conversa muito boa, muito bonita, com um trajecto, assim, com muitas curvas, mas eu acho que faz parte do processo [...], nós fomos fazendo a trajectória conforme as nossas memórias, as nossas recordaçōes (Isabel).

[...] foram momentos de muito prazer, eu gosto de fazer isso, eu gosto de contar histórias, eu gosto de voltar às minhas lembranças, eu faço isso de uma forma leve, mesmo que não sejam lembranças tão agradáveis, é agradável pra mim retomá-las (Hélida).

Suas narrativas indicam também contribuições e sentidos que encontraram na vivência da investigação. $\mathrm{Na}$ análise de conteúdo das avaliações orais, percebemos que a narrativa de suas histórias de vida com enfoque sobre as experiências formativas tecidas ao longo da vida favoreceu a reflexão sobre a trajetória de vida como um processo de aprendizagem e conhecimento, a expressão das experiências de vida como testamento da docência e a valorização do saber construido na trajetória profissional. Dessa forma, expressaram, a partir da singularidade de suas análises, sentidos que dialogam entre si, mas também dialogam com as questôes formuladas pela presente investigação e com a revisão da literatura desenvolvida.

Em suas reflexões orais e escritas, percebemos grande recorrência nesse aspecto, ou seja, na oportunidade reflexiva que viveram na rememoração

\footnotetext{
4 Registro da reflexão escrita feita pela professora.
} 
- uma reflexão laboriosa e, potencialmente, transformadora. A investigação mobilizou um processo reflexivo que, segundo as professoras, dificilmente viria de outra forma, já que se acham sempre envolvidas com muitas demandas e, no cotidiano, sentem que há falta de tempo para refletir: "Se calhar, claro que nós pensamos todos os dias, mas desta forma continuada deste percurso, se calhar, isso não iria acontecer e agora [...]” (Ana); “[...] esses momentos são momentos de uma importância muito grande e que, na nossa profissão, de vez em quando, temos que os fazer, por iniciativa própria nós nunca os fazemos, porque nunca temos tempo [...]" (Isabel).

Porque, enquanto nós estamos na prática, enquanto estive a trabalhar, nós, por vezes, nem temos tempo de reflectir. Fazemos, dá resultado, conseguimos atingir os objectivos, então vamos continuar, mas sem reflectirmos sobre até que ponto é que tudo isso pode ser um contributo muito importante, através das partilhas (Carolina).

Os encontros levaram as professoras a um processo de reflexão que ultrapassou a entrevista, e as indagações e análises permaneceram, foram levadas para casa, ocuparam outros tempos e espaços. Vemos isso nas falas de Carolina - cuja participação na investigação levou-a, além de refletir, a escrever outras histórias - e Rute:

[...] quando, às vezes, começo a pensar em coisas que disse, penso, 'Ah, olha outra, já esqueci-me, olha este também era interessante', pronto, estas coisas assim. Por acaso até está aí numa folhinha uma coisa interessante que eu, depois, me lembrei e acrescentei aqui (Carolina).

[...] É, voltar e ver e reconhecer como cada uma dessas coisas me construiu [...], eu saía daqui pensando em outras coisas. 'Ah, isso também aconteceu, olha, como eu estou agindo, como é reflexo daquilo que eu aprendi e hoje eu faço dessa maneira’; eu comecei a buscar outras histórias (Rute).

A narrativa de suas histórias de vida levou as professoras ao sentido formador da vida, a "voltar, ver e reconhecer como cada uma dessas coisas me construiu [...]" (Rute); "e eu acho que isso foi o que me marcou nessa experiência com essa pesquisa, entendeu? É, de ter olhado a minha história como for- 
madora, como formação. É, pensar, assim, as pessoas são feitas, são formadas daquilo que elas vivenciam, daquilo que elas experienciam [...]” (Hélida). Sentidos construídos em uma tessitura partilhada tanto pela análise pessoal como pela contribuição da investigadora, especialmente nas discussões do terceiro encontro. Ao olhar em perspectiva para sua trajetória, Rute percebe como foi mudando, reconstruindo a prática educativa, a partir das tensões do cotidiano, mas em sua análise percebemos quanto essa mudança é difícil e lenta:

E foi legal isso, porque que você age dessa forma, o que te construiu e essa mudança; mudar a sua maneira de pensar, de agir como é difícil, você romper com seus esquemas com a sua [...], é difícil, é um processo que você está construindo a todo tempo [...] Estamos sempre mudando, pensando, refletindo e eu sei que ainda tem muita coisa pra caminhar ainda aí (Rute).

Observamos, assim, que, de uma forma singular, a experiência narrativa vivida pelas professoras ao longo da investigação favoreceu um espaço-tempo importante quanto ao parar o curso do tempo, retomar e reconstruir experiências de vida e sentidos da formação. Se, por um lado, a experiência de investigação-formação não nos permite prever, mas apenas desejar e sonhar múltiplos futuros possíveis, por outro, apresenta indicativos do sentido formador da experiência narrativa, pois, ao refletir sobre o passado, as professoras reconstroem suas histórias em uma intensa tessitura da intriga. Na leitura das transcrições, muitas professoras criticaram suas próprias narrativas pelas repetições, idas e voltas; contudo, retomando as transcrições integrais, afirmamos que encontramos ali, em cada uma, uma história que pode ser seguida, que indica pistas, vestígios de uma versão de si que se constrói e se reconstrói.

Para as professoras, a participação na pesquisa foi uma oportunidade de viver a experiência narrativa do tempo como tríplice presente - tal como expressa Ricoeur (1994), apoiado em Santo Agostinho. Em cada encontro, o passado tornou-se presente pela memória, e o futuro, pela previsão, pelos desejos e projetos que se abriram. O passado fez-se presente, reconstruído, refeito na reflexão. O convite para a narrativa dos acontecimentos instituintes de formação ao longo da trajetória de vida exigiu das professoras atuação propositiva de sujeitos do conhecimento na seleção e atribuição de novos sentidos e interpretaçôes; passados esquecidos, histórias, episódios pontuais vieram à tona no processo narrativo, e a necessidade de constituição de um relato não episódico, 
mas de uma história que pudesse ser seguida, exigiu trabalho laborioso de tessitura da intriga, traduzindo a experiência narrativa em formação.

$\mathrm{Na}$ vivência da pesquisa, refletimos sobre o sentido formativo da experiência narrativa das professoras. Entretanto, é preciso também referir que ouvir a história das professoras mobilizou um intenso movimento de reflexão e de formação na investigadora:

Sinto-me esgotada! Emocionalmente, afetivamente esgotada ou mesmo triste. A entrevista com Hélida foi intensa, foi tão forte [...] Viajei por minha própria história em momentos muito difíceis, refleti com ela sobre os sentidos da pesquisa e minhas angústias nesse movimento. As dificuldades da infância, a religiosidade forte, o sentimento de compaixão, de certo sofrer com e pelo outro. Nossas vidas se tocam em singularidades e diferenças. Me vejo no que temos em comum, mas me vejo na diferença. A imagem da menina-mulher forte, a imagem da menina-mulher vista como frágil, mas que na fragilidade desenvolve a força nem sempre vista. Uma formação ampla, cultural, dialogada com o mundo. Uma formação interior, um investimento pessoal. Ouvir a história de Hélida coloca-me frente ao que eu mesma sou, minhas fragilidades, alguns caminhos que trilhei e outros apenas desejados. Tive o sentimento de me descortinar e não apenas de descortinar o outro (10 ago. 2006).

Ao ouvirmos a história do outro, refletimos sobre nossa própria trajetória. Assim, a investigação-formação foi abrindo canais para uma aprendizagem partilhada na tematização de percursos de vida.

Voltando aos eixos/questões de análise da investigação, o segundo conjunto de questões aponta as diversas dimensões da trajetória de vida e formação dos/as professores/as. Tanto no exercício memorialístico de pavimentação do passado, desenvolvido pelas professoras em cada um dos encontros, como no trabalho desenvolvido pela investigadora nas transcrições, análises e na elaboração escrita da biografia educativa, observamos a visibilidade e a potencialidade formadora das diversas dimensões da trajetória de vida. A história de cada professora tece experiências que entrelaçam aprendizagens que vêm do âmbito pessoal, da trajetória de formação acadêmica e profissional e, como analisamos no capítulo anterior, o desdobramento das diferentes fases e etapas da vida vai se dando pela tensa mediação entre elas. Na montagem do 
gráfico das experiências instituintes de formação, ${ }^{5}$ sentimos a dificuldade das professoras em indicar a intensidade formadora dos acontecimentos biográficos e podemos levantar indícios de que esse fato ocorra justamente porque o processo formador só é inteligivel em uma perspectiva que entretece os diferentes episódios em uma tessitura, na qual as intrigas são articuladas na experiência narrativa como uma história que pode ser seguida. Uma história que não estava dada previamente ao sujeito, mas que é reconstruida no ato narrativo.

$\mathrm{Na}$ análise dialógica das 12 narrativas, encontramos, contudo, pistas importantes sobre sentidos dessas dimensöes, especialmente daquelas que, geralmente, não são referidas quando analisamos a formação docente, como a formação pessoal e as experiências da trajetória escolar. A formação pessoal, os valores e os princípios aprendidos junto ao núcleo familiar mais próximo e também em sua ampliação para os diversos grupos sociais de que participam ao longo da vida aparecem como marcos fundamentais que se reatualizam de diferentes formas, mas que mostram sua presença fundacional. Ainda a trajectória escolar como alunas, especialmente da escola primária, aponta a construção de imagens e saberes sobre a docência e a prática educativa - para algumas, como imagens a seguir; para outras, como formação às avessas, ou seja, como referência do que não desejam como imagem de si.

Apesar da referência técnica da formação inicial, em nivel médio, as professoras registram a importância desse tempo como "preparação" para a docência; já os eventos de formação contínua, de forma geral, não receberam destaque como acontecimentos biográficos. Nesse aspecto, encontramos singularidades na narrativa de três professoras que viveram experiências consideradas transformadoras de suas concepções e práticas. A realização da licenciaturalgraduação, situada em contexto de formação contínua, já que oito das dez professoras que realizaram formação superior fizeram o curso ao longo da vida profissional, foi referida como acontecimento relevante, que se desdobrou em intensos momentos de reflexão e reconstrução das práticas. O decorrer da trajetória profissional vem como espaço-tempo fundamental de formação, "de busca de reconstrução das formas de ser e de estar na docência; a dinâmica das relações entre escola, alunos, colegas, famílias, contextos sócio-histórico-culturais, conteúdos, currículos geram dúvidas, desafios, e os saberes construídos são

5 Cf. Anexo 7. No capítulo 5, apresentamos a forma como esse gráfico foi construído pelas professoras como uma das etapas do processo de investigação-formação proposto. 
colocados em questão e levam as professoras ao movimento" 6 e a uma sempre nova tessitura de concepçôes e práticas.

Considerando o diálogo estabelecido entre as trajetórias de vida, procuramos dar relevo, na figura 6 , aos acontecimentos biográficos que mais se destacaram na formação das 12 professoras:

Figura 6: Acontecimentos biográficos que mais se destacam na formação das professoras participantes da investigação-formação

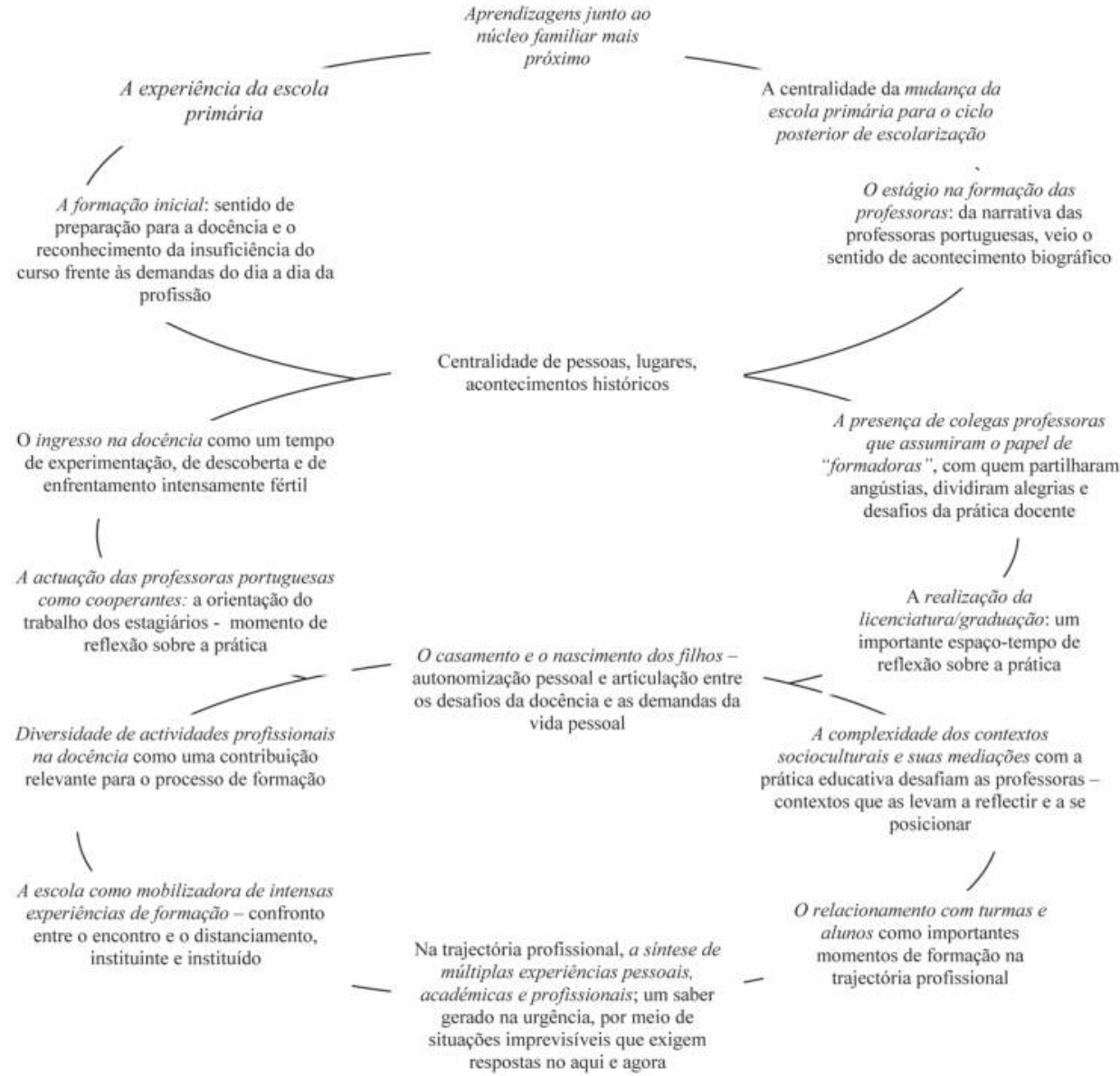

${ }^{6}$ Análise desenvolvida no capítulo 7. 
Como no caleidoscópio, a conjugação desses diferentes componentes gerou, na singularidade da vida de cada professora, diferentes sentidos e intensidades.

Voltando o olhar novamente para os eixos/questôes da investigação, no terceiro conjunto, encontramos a importância da narrativa das histórias de vida das professoras como "testamento da docência". Ao longo de cada um dos encontros, tivemos a oportunidade de viver uma intensa experiência de aprendizagem com as professoras, e o desenvolvimento da investigação foi reafirmando o sentido da docência como "lugar de memória" (Nora, 1993) e a contribuição do registro da história de vida como "testamento"(Arendt, 1972), abrindo a possibilidade de que outras pessoas, na leitura desses testamentos, possam também vivenciar uma experiência de aprendizagem que transforme biografia em herança.

Procuramos nos embrenhar nas histórias ouvidas e transcritas, reescrevendo-as em formato de biografia educativa, e, nesse movimento, foi necessário ter cuidado epistemológico, reflexividade crítica, mas especialmente preocupação ética, para contar a história respeitando os vestígios de sentidos deixados pela narradora e, ao mesmo tempo, tornar mais visível a tessitura da intriga que constitui o processo formador, foco da presente investigação. Logo, no texto das biografias, tentamos deixar que as professoras contassem suas histórias, expressassem suas vidas como testamento da docência.

$\mathrm{Na}$ avaliação oral e na escrita, encontramos na fala de três professoras a importância dessa dimensão:

[...] se houver uma leitura a posteriori, pode ser que alguém que faça essa leitura possa aprender alguma coisa e que retire, deste documento e desta entrevista que fizemos, as coisas positivas da vida e da profissão, que é isso que é interessante $[. .$.$] para que haja um leque maior de pessoas a ler e a refletir$ sobre isso, ajuda muito, é um crescimento para toda a gente (Teresa).

Acho que vale a pena este tipo de trabalho, mas que não fique depois só fechado. Que todas as conclusōes tiradas deste tipo de trabalho possam ser transmitidas para que as pessoas também possam ter conhecimento até que ponto é que podem continuar ou mudar a sua actuação, das práticas pedagógicas. É através dessa experiência, desse relato de experiências, que muito também se pode aprender, porque aí já não é só a teoria, não, estão ali factos verídicos, 
é a experiência que fala e, de facto, é muito mais importante nós podermos depois tirar algo dessa escrita (Carolina).

Bom, avaliação, no meu modo de pensar, é a melhor possível, porque só assim que a gente pode passar pra pessoa a bagagem que a gente tem, de tudo que a gente fez na vida profissional dentro dos métodos de ensino, todos os problemas que a gente viveu naquela época e que até hoje vive [...] E é, no meu modo de pensar, tudo isso que eu passei pra você eu não teria condição, assim, por exemplo, de passar para outra pessoa se não fosse através desse trabalho seu, porque eu nunca tive oportunidade pra comentar, pra conversar, pra falar, pra passar para os outros as minhas experiências de vida. Foi muito bom poder falar aquilo que eu guardava só pra mim. Guardava só pra mim toda a minha experiência de vida profissional (Marta).

É interessante observar que Carolina e Marta, professoras aposentadas, uma em Portugal e outra no Brasil, e Teresa, que na ocasião das entrevistas já trabalhava havia 23 anos na docência, destacaram a importância da narrativa de suas histórias como um testemunho para aqueles que estão atuando. Há um saber produzido e construído pelas professoras no exercício da profissão e que precisa ser valorizado, socializado: "É importante ser valorizado, de certa forma, o nosso percurso de vida. Normalmente não é assim muito valorizado, não é muito bem dissecado ou as escolas não têm atenção quem são os professores, o conhecimento próprio dos professores" (Clara). Nesse mesmo sentido, Isabel destaca que as professoras de sua geração não desenvolveram o importante hábito do registro, o que leva muitas experiências a se perderem, pois ficam só entre a professora e a "almofada":

Com a almofada, nós ainda vamos fazendo, de vez em quando, na almofada ou assim numa conversa, mas aquelas conversas sempre fugidias, na almofada fica tudo no ar, porque nem eu registo, nem a almofada regista, e há uma cultura muito negativa: portanto, nós, professores, pelo menos nos da minha geração. Porque eu agora já vejo os da geração da Clara e já têm hábitos de registo e nós não, foi uma geração que nunca cultivou o registo. Isso é muito mau na nossa profissão, porque, quantas vezes, nós, quando estamos assim a falar, nós relembramos e dizemos 'Olha aqui, pois isto já até me tinha passado 
etc.', e isso faz com que a falta de registo desvalorize muito a nossa profissão [...] (Isabel).

$\mathrm{Na}$ reflexão de Isabel, encontramos a necessidade do registro como afirmação dos saberes construídos pelos/as professores/as, que, dessa forma, também apresentam a possibilidade de constituir testamentos e heranças.

Mesmo já assinaladas as "reflexões (in)conclusivas" sobre a potencialidade instituinte da experiência narrativa na formação docente, a articulação de diferentes dimensões formadoras na tessitura das intrigas e as histórias de vida como possibilidade de expressão do testamento da docência, buscamos ainda o sentido dialógico da pesquisa e da formação, sentido que, como afirmamos, foi se colocando e se delineando em caminhos ao longo da investigação, constituindo, dessa forma, o quarto eixo desta.

A presença e o desenvolvimento de uma etapa significativa do trabalho de pesquisa em Portugal nos levaram a perspectivas de diálogo que se desdobram. A primeira perspectiva foi incluída inicialmente como um dos objetivos do projeto de investigação e consistiu na realização de um estudo exploratório da produção bibliográfica no campo da formação de professores, em Portugal e no Brasil, dos anos 1980 aos dias atuais, tendo em vista a análise dos pressupostos epistemológicos gerais que sustentam a pesquisa nesse campo e, nomeadamente, a presença da abordagem teórico-metodológica das histórias de vida. ${ }^{7}$ Recebemos no Brasil grande influência da produção portuguesa nesse campo e procuramos, então, delinear a produção nessa área de estudos, inclusive para situar a investigação em pauta, e, assim, realizamos uma revisão de literatura dialógica, incluindo também a produção francófona.

Mas o diálogo foi se desdobrando e, com o objetivo de construir referências sócio-históricas para a análise das biografias educativas, incluímos o estudo da contextualização, ${ }^{8}$ que sinalizou pontos de contato entre o caminho percorrido, as tensões históricas e os desafios da escola, da docência e da formação de professores em Portugal e no Brasil. Nessa dimensão, buscamos destacar alguns vestígios que nos ensinam tanto pela proximidade de configuraçôes e desafios que nos unem e nos aproximam como pelo que temos de singular e, assim, talvez, nosso trabalho possa indicar um convite à reflexão

Objetivo definido no projeto de investigação.

8 Considerando a necessidade de redução do texto para a publicação, o estudo de contextualização não foi inserido neste livro. 
que insiste em se colocar toda vez que nos confrontamos com as semelhanças $e$ singularidades que nutrimos em relação ao outro.

Como pontos de encontro, temos os amplos sentidos do processo formador, que, sendo pessoal, humano e historicamente construídos, apresentam-se como tessitura da intriga e fruto da experiência narrativa, conjugando dialeticamente as múltiplas dimensões da vida. Temos também, na particularidade dos relatos, a experiência de uma angústia comum frente às novas formas de organização social contemporânea, ou seja, a percepção de uma crise no paradigma societário que interfere diretamente nas políticas públicas, nas instituições escolares e nas relaçôes entre escola-comunidade-familia-alunos, trazendo novas exigências e desafios para a práxis docente e a formação. Porém, em relação dialética com a angústia, encontramos nas professoras participantes a docência como um lugar de prazer, de realização pessoal, sentimento expresso especialmente quando falam da alegria de viver com os alunos momentos de ensinar e aprender e do sucesso de seus ex-alunos e quando são lembradas por eles com gratidão e reconhecimento. Mas também falam da tristeza que sentem quando "fracassam" em seus sonhos e projetos. Para elas, a docência é um lugar de contraditórios sentimentos e desejos, mas no qual desejam, de diferentes formas e pela confluência de diferentes fatores, permanecer.

Contudo, se esta análise, como todas as demais, precisa ser contextualizada em um pequeno grupo de 12 professoras, seis portuguesas e seis brasileiras, e se o objetivo destas "reflexões (in)conclusivas" não é mesmo a generalização, podemos tentar aprender com os vestígios. $\mathrm{O}$ grupo de professoras foi escolhido buscando-se a variedade das experiências formadoras, portanto a diversidade sociocultural materializada em um grupo de professoras de diferentes faixas etárias, tempo de magistério e locais de residência e trabalho. Entretanto, buscamos uma característica comum: o envolvimento com a docência. Podemos, então, supor que as professoras participantes não falam de todas, mas também não falam apenas de si mesmas. Representam um grupo, falando, assim, de outras tantas professoras que não foram ouvidas, mas que de diferentes formas também desejam continuar construindo a docência do $1^{\circ}$ ciclo em Portugal e dos anos iniciais do ensino fundamental no Brasil. Mulheres professoras que entrelaçam vida, docência e formação.

Mas aprendemos também no confronto de singularidades. No diálogo entre Brasil e Portugal, percebemos, por um lado, que na formação acadêmica o componente ligado ao estágio aparece com mais força instituinte de for- 
mação na narrativa das professoras portuguesas do que na das brasileiras. Por outro, as tramas da formação contínua aparecem com mais intensidade no relato de duas professoras brasileiras que, sem exigência formal do sistema, encontraram na realização de diferentes cursos a continuidade de um caminho de formação.

Olhando, entretanto, para o grupo das professoras como um todo, encontramos possibilidades de análise dialógica que extrapolam as fronteiras entre Brasil e Portugal. Quando ampliamos o olhar, percebemos, por exemplo, entre Ana e Hélida, a escrita reflexiva como um traço importante de formação; entre Carolina e Marta, professoras aposentadas, diferentes formas de permanecer ligadas à docência em um fazer permanentemente reinventado; entre Tereza e Eloisa, uma aguçada visão crítica sobre as políticas públicas, a escola e a formação docente; entre Ana, Isabel e Clara, a centralidade das escolas por que passaram na mobilização de um intenso processo formador. Reafirmamos, assim, uma aprendizagem que se dá quando nos confrontamos com o outro, um legitimo outro que pode estar ao nosso lado, trabalhando na mesma escola, ou outro que não conhecemos, distanciado pelo Atlântico, mas do qual nos aproximamos. Trazendo a contribuição da educação comparada, reafirmamos o sentido de "comunidade imaginada" (Nóvoa, 1995a, 2000; Nóvoa et al., 2003), à qual dialeticamente nos ligamos e da qual nos distanciamos, mediados por desejos, lutas, conflitos e desafios comuns e singulares.

Após a reflexão mediada pelos diferentes eixos da investigação, destacamos uma das questôes inicialmente propostas: o trabalho com as histórias de vida em contexto de formação de professores/as pode contribuir para a busca de uma racionalidade mais humana, sensivel e partilhada? O desenvolvimento da investigação-formação trouxe indicativos de sentidos do movimento de formação como tessitura pessoal-coletiva complexa que se desenvolve em diferentes espaços e tempos materiais e simbólicos e que dizem respeito às múltiplas possibilidades humanas frente à aventura do conhecimento. Um dos caminhos para mobilizar aprendizagens se dá quando refletimos sobre a trajetória de vida e, envolvendo a globalidade da vida ou recuperando experiências singulares, reconstruímos, na dinâmica do tríplice presente, sentidos da trajetória, vivendo a formação como experiência narrativa. Nesse movimento, diversos saberes são tecidos em um permanente atravessamento entre teorias e práticas, conteúdos culturais, científicos e existenciais, na trilha de um conhecimento emancipatório (Santos, 2000) e de uma racionalidade instituinte. 
Tomando como desafio a reconstrução do projeto emancipatório da modernidade, Santos nos desafia a pensar a teoria crítica em uma abordagem pós-moderna de oposição, na qual o conhecimento se dá pelo reconhecimento do outro como sujeito:

Nessa forma de conhecimento, conhecer é reconhecer, é progredir no sentido de elevar o outro da condição de objecto à condição de sujeito. Esse conhecimento-reconhecimento é o que designo por solidariedade. Estamos tão habituados a conceber o conhecimento como um princípio de ordem sobre as coisas e sobre os outros que é difícil imaginar uma forma de conhecimento que funcione como princípio de solidariedade. No entanto, tal dificuldade é um desafio que deve ser enfrentado (2000, p. 29).

Esse desafio se desdobra no reconhecimento do outro como produtor de conhecimento, manifestando a inteligibilidade das diferenças, portanto, em um conhecimento multicultural, na vivência partilhada e desprofissionalizada do conhecimento, tomando o sentido da dupla ruptura epistemológica em que senso comum e conhecimento científico retornam ao senso comum como possibilidade de socialização e transformação e, finalmente, no desafio que vai "da acção conformista à acção rebelde" (Santos, 2000), que, na particularidade da análise deste estudo, afirma-se na busca por um movimento de formação que contribua para a construção de subjetividades inquietas, inconformadas. Nesse sentido, a racionalidade instituinte que mencionamos assenta-se nesse conhecimento emancipatório que alia concepçóes e práticas, ciência e existência, poièsis e poesia e que, como saber partilhado, aponta também o sentido narrativo que o constitui e movimenta.

Percebemos, assim, uma reflexão filosófica que se coloca quando tematizamos a formação, a construção do conhecimento historicamente humano, dialeticamente ligado às possibilidades de uma atuação que se deseja emancipatória. Nesse sentido, é pertinente questionar: que desejos de futuro a presente pesquisa abre quanto às concepções-ações de formação docente no Brasil e em Portugal? Começamos nossa problematização analisando a ênfase em um paradigma de formação transmissivo e na dificuldade de caminhos dialógicos entre diferentes dimensões formadoras. As reflexões tecidas indicam a possibilidade de que os espaços destinados à formação acadêmica dos professores, passando pelas diferentes modalidades de formação inicial e contínua e por 
movimentos formativos desenvolvidos em contexto escolar, abram espaço-tempo de encontro dialógico de partilha de experiências em um intercâmbio de saberes cientificos, culturais e existenciais, que gradativamente já não se expressem por suas especificidades, mas pela polifonia entre eles.

Retornando à metáfora da pesquisa como "sopa de pedra", os eixos e as questôes se colocaram como ingredientes e, na preparação de cada um deles, foi necessário aprender a forma de tratamento específico, o tempo de cozimento, a panela adequada:

E, se essa sopa tem uma receita, em conversa com minhas amigas portuguesas percebi que o que caracteriza sua própria origem é a possibilidade de fazer um saboroso prato, quente e inspirador, a partir do que temos, dos ingredientes de que dispomos e que, alquimicamente, vão dando sabor e sentido (1ํㅡov. 2005). ${ }^{?}$

Assim, outros ingredientes foram acrescentados ao longo da preparação e, na alquimia que envolve a culinária e a pesquisa, cada um deles foi transformado na composição de um prato que congrega a dialética entre um sabor de conjunto e a peculiaridade de cada ingrediente que pode ser percebido e sentido em sua singularidade.

Ao longo da pesquisa, passamos pelo preparo, tempero, cozimento de cada um desses ingredientes em seu tempo e vimos se desdobrarem as dinâmicas de estudo e pesquisa que geraram sínteses sobre a trajetória das histórias de vida no campo das ciências sociais e humanas, o diálogo entre literatura educacional da área, o referencial teórico-metodológico e a experiência de pesquisa vivida com as professoras. O preparo de cada um se deu em ordem kairótica, mediados pelo tempo da oportunidade, de conhecimento e de um tempo cheio de idas e voltas. Assim, muitos ingredientes subverteram o indicado na "receita", demandando mais tempo, mais tempero, novos cuidados. $\mathrm{Na}$ cozinha, fomos fazendo aos poucos ensaios de mistura, experimentando, ainda que de forma fragmentada, indícios de sabores, sentindo cheiros desorganizados que teimavam em invadir a cozinha. Hoje, buscamos o sabor da "sopa", sabendo que cada um que a experimentar viverá uma experiência singular de sentidos, mas que, como toda experiência, pode ser partilhada por

\footnotetext{
9 Trecho do livro da vida citado na apresentação da tese que originou este livro.
} 
meio da narração. Voltando às três etapas da mimese propostas por Ricoeur (1994) e às possibilidades da pesquisa como poièsis, vivemos com as professoras uma experiência que se situa no campo da ação. Ao longo do texto, reconstruímos narrativamente essa experiência e agora, em sua socialização, convidamos às múltiplas leituras e reconstruções.

Desejamos, entretanto, (in)concluir com a voz de uma das professoras-investigadoras que, a partir da proposta de avaliação escrita, escreveu uma crônica sobre a experiência narrativa de formação como "túnel do tempo":

\section{O caleidoscópico túnel do tempo}

Faz pouco tempo, fui chamada para uma experiência científica. O convite partiu de uma pessoa muito cara, um ícone dos tempos da faculdade. $\mathrm{O}$ projeto consistia em entrarmos juntas em um túnel que nos levaria ao reino da memória, lugar quente, cheio de surpresas... Mesmo o contato telefônico que trouxe o convite já empurrava o pensamento pra dentro do túnel, mas os rigores da pesquisa previam artimanhas inacreditáveis.

Eu mal sabia o que estava me esperando. A primeira sessão iniciou com um emaranhado de sensaçóes. Misturavam a viagem ao ponto de encontro, acompanhada de uma espécie de assistente da pesquisa que eu nem conhecia, pequenas delícias de um lanche, uma conversa descontraída, um clima inocente. Pouco a pouco fui me deixando levar, fui ficando solta, as palavras se encaixavam em histórias tristes e alegres. As espirais se desenrolavam e a entrada do túnel já podia ser vista. Foi então que surgiram as regras; sim, elas existiam, não eram poucas, mas também não eram difíceis de cumprir. Ademais, eu me encontrava, naquele momento, definitivamente seduzida pelo caminho que se abria. E já tínhamos completado a etapa inicial dessa jornada que eu nem imaginava aonde ia nos levar.

Para a etapa posterior, eu deveria estar acompanhada. Um objeto. Levei dois. Sou irridenta. Um deles me levava a tempos gostosos e ao mesmo tempo cheio de conflitos: os tempos de adolescente; jovem e um tantinho bela, despertava paixôes que nunca tiveram fim. O outro objeto trazia alguém: a avó querida, com quem aprendi tanta coisa. E sua chegada trouxe o pai, a mãe, a infância guardada. Trouxe alegria e nostalgia. Revirou lembranças e ressignificou quase tudo. Túnel estranho; começa pelo mais profundo, pelo mais 
antigo. Bagunçou meu tempo! E depois de penetrar tão fundo tinha que sair bruscamente e voltar à normalidade, à espera de um novo mergulho.

Os encontros cumpriam um rito bem-definido: primeiro a viagem com aquele assistente que já ia me preparando, o lanche sempre saboroso, a conversa mansa e doce que parecia me hipnotizar e então: tchiboom! Eu sentia o envolvente interior do tal túnel. Visitei os tempos de escola, templos onde encontrei a mim mesma e me tornei quem sou: Educadora. Aprendi que muito aprendi quando da escola fugi. Fiz poesia com o lembrar, o coração muitas vezes batia num compasso acima, não sei bem por quê. $\mathrm{O}$ ambiente era calmo, a memória tranquila, mas ele insistia: tum-tum, tum-tum, um tantinho mais rápido. Sensação gostosa. E o repente exigia, já chega, hora de voltar.

Mesmo num ponto mais superficial desse túnel, esse momento do trabalho foi turbilhão. Cutuquei o recente das minhas lembranças com esse olhar de antes. Era, de repente, a menina que se percebia mãe. Era aluna levada, que se via com tantos alunos diante de si. Era bonitinha e amargurada. Tinha fé, mas também duvidava. Saí do túnel com os cabelos embaraçados, assim como estavam as lembranças. Gostei. Percebo agora que o que senti era como o que sinto num daqueles brinquedos bem loucos dos parques de diversão. $\mathrm{O}$ último encontro foi para revisitarmos todos aqueles pontos do túnel, era hora de assentarmos o que vimos, de respirar e refletir sobre o que vivemos. Fechamos elos que deixamos largados em outros momentos. E assim pude me deter em cada etapa do túnel, escorreguei mais devagar pela espiral, fui catando os retalhos para arrumá-los e costurar depois.

É o que estou fazendo agora. Faz parte do contrato. E me parece que, quando saí do túnel pela última vez, saí diferente, transformada. Tanto a pessoa presente, o que era de se esperar, afinal uma experiência assim tão intensa tinha de deixar fortes resultados, como o passado foram modificados, o que eu não esperava; acho que nunca mais vou recordar como antes. E aquele caleidoscópio que levei no início me serve outra vez para entender. O colorido desse túnel de memórias, suas múltiplas formas-significados, só as posso ver se for girando as lembranças, mas sempre de olhos fechados (Hélida). 


\section{Referências}

ABDALLA, Maria de Fátima Barbosa. Formação e desenvolvimento profissional do professor: $o$ aprender da profissão (tese). USP, 2000.

ABELS, Christine. "L'accompagnement de l'enfant placé dans son travail d'histoire de vie". In PINEAU, Gaston (org.). Accompagnements et histoire de vie. Paris: L'Harmattan, 1998. ABRAHÃO, Maria Helena Menna Barreto. "As narrativas de si ressignificadas pelo emprego do método autobiográfico". In SOUZA, Elizeu Clementino de (org.). Tempos, narrativas e ficções. Porto Alegre: EdiPUCRS/Salvador: EdUNEB, 2006a.

—_. "Profissionalização docente e identidade - narrativas na primeira pessoa". In SOUZA, Elizeu Clementino de (org.). Autobiografias, histórias de vida e formação: pesquisa e ensino. Porto Alegre: EdiPUCRS/Salvador: EdUNEB, 2006b.

$\mathrm{ADÃO}$, Áurea. "A história da profissão docente em Portugal: balanço da investigação realizada nas últimas décadas”. In NÓVOA, A. e BERRIO, J. R. (org.). A história da educação em Espanha e Portugal. Lisboa: Sociedade Portuguesa de Ciências da Educação, 1993, pp. 123-35.

ALARCÃO, Isabel. Formação reflexiva de professores: estratégias de supervisão. Porto: Porto, 1996. - et al. A formação de professores no Portugal de hoje. Documento de trabalho do Conselho de Reitores das Universidades Portuguesas (CRUP). Disponível em http://www.educ.fc.ul. pt/docentes/jponte/docs-pt/97-Alarcao-Ponte-etc.doc. Acesso em ago. 2005.

ALAVA, Séraphin. "Pratiques d'autoformation des enseignants novices ou l'autoconstruction professionnelle". Education Permanente, 1995, v. 1, n. 122, pp. 79-93.

ALMEIDA, Cybele Crossetti. "O magistério feminino laico no século XIX". Teoria e Educação, 1991, n. 4, pp. 159-71.

ALMEIDA, Jane Soares. "Mulheres na escola: algumas reflexões sobre o magistério feminino". Cadernos de Pesquisa, 1996, n. 96, pp. 71-78.

—. "Magistério primário em Portugal: conquista feminina do início do século". Cadernos de Pesquisa, 1997, n. 102, pp. 65-88.

ALTET, Marguerite. "Les compétences de l'enseignants-professionnel: entre savoirs, schèmes d'action et adaptation, le savoir analyser". In PAQUAY, Léopold et al. (eds.). Former des enseignants professionnels: quelles stratégies? Quelles copétences? 3 ed. Bruxelas: De Boeck Université, 2001. 
—. "Lanalyse de pratiques en formation initiale des enseignants: développer une pratique réflexive sur et pour l'action". Education Permanente, 2004, v. 3, n. 160, pp. 101-60.

ALVES, Francisco Cordeiro. O encontro com a realidade docente: estudo exploratório (auto) biográfico (tese). Universidade de Lisboa, 1997.

- - O encontro com a realidade docente: ser professor principiante. Lisboa: Instituto de Inovação Educacional, 2000.

AMBRÓSIO, Teresa. "Exigências de investigação multidisciplinar em formação. Actas do Colóquio da Sociedade Portuguesa de Ciências da Educação”. Estado actual da investigação e formação. Porto: Afrontamento, 1994.

ANDRÉ, Marli Eliza D. A. "Perspectivas atuais da pesquisa sobre a docência”. In CATANI, Denice Bárbara et al. (org.). Docência, memória e gênero. São Paulo: Escrituras, 1997.

—. A pesquisa educacional: seus rumos e tendências atuais. Comunicação apresentada no III Seminário de Pesquisa em Educação da Região Sul. FACED/UFRGS, 2000.

—. O tema da formação docente nas teses e dissertaçôes brasileiras, 2001. Disponível em http:// www.educaoonline.pro.br. Acesso em ago. 2005.

ANFOPE. Documento final do X Encontro Nacional. Brasília, 2000.

ANTÓNIO, Ana Sofia e TEODORO, António. "Autorrepresentações das funções das professoras na escola”. Revista Lusófona de Educação, 2003, n. 2, pp. 83-97.

ARAGÃO, Rosália. "Compreendendo a investigação narrativa de acçôes escolares de ensino e de aprendizagem no âmbito da formação de professores”. Anais da XXVII Reunião Anual da Associação Nacional de Pesquisa e Pós-Graduação em Educação. Caxambu, 2004.

ARAÚJO, Alberto Filipe. "A voz pedagógica do mito de Hermes: para um novo espírito pedagógico". Revista Portuguesa de Educação, Universidade do Minho, 1991, v. 4, n. 3, pp. 107-13.

ARAÚJO, Helena Costa. "Procurando as lutas escondidas através das histórias de vida". Cadernos de Consulta Psicológica, 1990, n. 6, pp. 33-40.

—. "Uma outra visão sobre o professorado em Portugal". Colóquio Educação e Sociedade, 1993, n. 4, pp. 161-3.

. "Reconstruindo percursos e experiências de professoras primárias no período de transição da República para o Estado Novo". Actas do II Congresso da Sociedade Portuguesa de Ciências da Educação - Ciências da Educação: Investigação e Acção. Braga, v. II, pp. 351-6, 1995.

- As pioneiras na educação: as professoras primárias na viragem do século: contextos, percursos e experiências, 1870-1933. Porto: Afrontamento, 2000.

—_. "Em torno de subjectividades e de verstehen em histórias de vida de professoras primárias nas primeiras décadas do século XX”. In ABRAHÃO, Maria Helena Menna Barreto (org.). A Aventura (auto)biográfica: teoria e empiria. Porto Alegre: EdiPUCRS, 2004.

— e MAGALHÃES, Maria José. Des-fiar as vidas. Perspectivas biográficas, mulheres e cidadania. Lisboa: Comissão para Igualdade e para os Direitos das Mulheres, 2000.

ARAÚJO, Helena Costa e STOER, Stephen R. Genealogias nas escolas: a capacidade de nos surpreender. Porto: Edições Afrontamento, 1993.

ARENDT, Hannah. Entre o passado e o futuro. São Paulo: Perspectiva, 1972, pp. 28-42.

ARISTÓTELES. Arte poética. São Paulo: Martin Claret, 2006.

ARROYO, Miguel G. Ofício de mestre: imagens e autoimagens. Petrópolis, RJ: Vozes, 2000. 
ASTIER, Philippe. "Activité et situation dans le 'récit d'expérience”. Education Permanente, 1999 , v. 2, n. 139, pp. 87-97.

AZAMBUJA, Guacira de e OLIVEIRA, Valeska Fortes de. Processos de formação de um professor, 2001. Disponível em http://www.educaoonline.pro.br. Acesso em ago. 2005.

AZZAN, J. C. Antropologia e interpretação. Campinas: Unicamp, 1993.

BALANDIER, Georges. "Préface". In FERRAROTTI, Franco. Histoire et histoires de vie: la méthode biographique dans les sciences sociales. 2 ed. Paris: Méridiens Klincksieck, 1990.

BALESTRAT, Christine. "Histoire de vie et alphabétisation: une pratique et son analyse". Education Permanente, 2000, v. 1, n. 142, pp. 147-57.

BARBIER, Jean-Marie. "La recherche de nouvelles formes de formation par et dans les situations de travail”. Education Permanente, 1992, n. 112, pp. 125-46.

—. "Tendances d'evolution de la formation er place du partenariat". Actas do Colóquio Estado Actual da Investigação e Formação. Sociedade Portuguesa de Ciências da Educação, Porto: Afrontamento, 1994.

— (org.). Savoirs theóriques et savoirs d'action. Paris: Presses Universitaires de France, 1996a.

- "De l'usage de la notion d'identité en recherche, notamment dans le domaine de la formation”. Education Permanente, 1996b, v. 3, n. 128, pp. 11-26.

BARBOSA, Manuel. "Figuras da racionalidade pedagógica para uma epistemologia do ofício de educador”. Revista de Educação, 1998, v. 7, n. 2, pp. 41- 52.

BARROSO, João e CANÁRIO, Rui. "Centros de formação das associações de escolas: práticas formativas e modos de gestão". Actas do Colóquio da Sociedade Portuguesa de Ciências da Educação - Estado Actual da Investigação e Formação. Porto: Afrontamento, 1994.

BASTOS, Maria Helena Câmara. "Memoriais de professoras: reflexões sobre uma proposta". In MIGNOT, Ana Chrystina Venancio e CUNHA, Maria Teresa Santos (orgs.). Práticas de memória docente. São Paulo: Cortez, 2003.

BAUDOUIN, Jean-Michel e TURKAL, Laurence. "Formations au singulier". Education Permanente, 2000, v. 1, n. 142, pp. 45-61.

BELKAID, Malika. "La vie en histoire(s)". Education et recherche, 1997, n. 2, pp. 224-5.

BEM-PERETZ, Miriam. "Episódios do passado evocados por professores aposentados". In NÓVOA, António (org.). Vidas de professores. Porto: Porto, 1992.

BENAVENTE, Ana et al. Do outro lado da escola. Lisboa: Teorema, 1991.

BENJAMIN, Walter. Obras escolhidas: Magia e técnica, arte e política. São Paulo: Brasiliense, 1993.

- Reflexões: a criança, o brinquedo e a educação. São Paulo: Summus, 1994.

BERNADOU, A. "Savoir théorique et savoirs pratiques. L'exemple médical”. In BARBIER, Jean-Marie (org.). Savoirs theóriques et savoirs d'action. Paris: Presses Universitaires de France, 1996, pp. 29-42.

BERRY, M. "Savoirs théoriques et gestion". In BARBIER, Jean-Marie (org.). Savoirs theóriques et savoirs d'action. Paris : Presses Universitaires de France, 1996, pp. 43-56.

BERTAUX, Daniel. Les récits de vie. Paris: Éditions Nathan, 1997.

BERTON, Jacques. "Récits de vie et intervention sociale". Education Permanente, 2000, v. 1, n. 142, pp. 159-68.

BESSIN, Marc. "La compression du temps: une déritualisation des parcours de vie?”. Education Permanente, 1999, v. 1, pp. 75-85, 138. 
BIANCHI, Henry. "Identité et épreuve du temps". Education Permanente, 1999, v. 1, pp. 19-27, 138.

BIDARRA, Maria da Graça. "Do grau de transmissividade das práticas de formação ao optimismo irrealista”. Revista de Educação, 2002, n. XI, v. 1, pp. 159-62.

BONDÍA, Jorge Larrosa. "Notas sobre a experiência e o saber de experiência". Revista Brasileira de Educação, jan.-abr. 2002, n. 19, pp. 20-8.

BONVALOT, Guy. "Pour une autoformation 'permanente' des adultes”. Education Permanente, 1995 , v. 1, n. 122 , pp. 139-46.

BOSI, Ecléa. Memória e sociedade: lembranças de velhos. São Paulo: Companhia das Letras, 1994.

BOURDAGES, Louise. "Laccompagnateur accompagné. La complexité relationnelle de la fonction doctorale avec les histoires de vie". In PINEAU, Gaston (org.). Accompagnements et histoire de vie. Paris: L'Harmattan, 1998.

BOURDIEU, Pierre. "A ilusão biográfica". In FERREIRA, Marieta de Moraes e AMADO, Janaina (orgs.). Usos e abusos da história oral. Rio de Janeiro: FGV, 2001.

BOURGAIN, Dominique. "Écriture, représentations et formation: préalables à un projet de formation à écriture pour des adultes”. Education Permanente, 1990, v. 102, pp. 41-50.

BOUTINET, Jean Pierre. "Brouillage des âges et quêtes identitaires". Education Permanente, 1999, v. 1, n. 138, pp. 9-18.

BRAGANÇA, Inês F. S. "A pesquisa educacional e a formação de professores". Revista Brasileira de Estudos Pedagógicos, Brasília, 1997, v. 78, n. 188-190, pp. 413-71.

—. "A produção do saber docente na escola: possibilidades emancipatórias da narração na formação permanente do educador". Revista Contexto e Educação, Ed. Unijuí, 1998, n. 50, pp. 97-124.

—. "Fragmentos autobiográficos: memória e formação contínua de professores". Revista Contexto e Educação, Ed. Unijuí, 2001a, n. 63, pp. 107-18.

. "Algumas imagens sobre docência e formação na década de 1960: revisitando a revista brasileira de estudos pedagógicos". Revista Brasileira de Estudos Pedagógicos, 2001b, v. 82, n. 200-202, pp. 7-14.

- "Memórias e práticas instituintes na escola". Anais da XXVI Reunião da Associação Nacional de Pesquisa e Pós-Graduação em Educação. Poços de Caldas, 2003.

. "Histórias de vida e formação de professores/as: um olhar dirigido à literatura educacional”. In SOUZA, Elizeu Clementino de e MIGNOT, Ana Chrystina Venancio. Histórias de vida e formação de professores. Rio de Janeiro: Quartet/ Faperj, 2008a, pp. 65-88.

. "O/A professor/a e os espelhos da pesquisa educacional". Revista Brasileira de Estudos Pedagógicos, 2009, v. 90, pp. 87- 101.

— e MAURÍCIO, Lucia Velloso. "Histórias de vida e práticas de formação". In PASSEGGI, Maria da Conceição e SOUZA, Elizeu Clementino de. (Auto)Biografia: formação, territórios e saberes. Natal/São Paulo: EDUFRN/Paulus, 2008, v. 2, pp. 253-71.

BRUN, Patrick e BACHELART, Dominique. "Histoires de vie et démarches collectives de construction d'histoire”. Education Permanente, 2000, v. 1, n. 142, pp. 105-14.

BRZEZINSKI, Iria e GARRIDO, Elsa. "Análise dos trabalhos do GT Formação de Professores: o que revelam as pesquisas do período 1992-1998". Revista Brasileira e Educação, 2001, n. 18, pp. 82-100. 
BUENO, Belmira Oliveira. Autobiografia e formação de professores: um estudo sobre representações de alunas de um curso de magistério (tese de livre docência). USP, 1996.

. "O método autobiográfico e os estudos com histórias de vida de professores: a questão da subjetividade”. Anais da XX Reunião Anual da Associação Nacional de Pesquisa e Pós-Graduação em Educação. Caxambu, 1997.

. "O método autobiográfico e os estudos com histórias de vida de professores: a questão da subjetividade". Educação e Pesquisa, 2002, v. 1, n. 28, pp. 11-30.

— et al. "Histórias de vida e autobiografias na formação de professores e profissão docente (Brasil, 1985-2003)”. Educação e Pesquisa, 2006, v. 32, n. 2, pp. 385-410.

BUENO, Belmira Oliveira et al. "Docência, memória e género: estudos alternativos sobre a formação de professores". Psicologia USP, 1993, v. 4, n. 1-2, pp. 299-318.

BURKE, Peter (org.). A escrita da história: novas perspectivas. São Paulo: Ed. Unesp, 1992.

CACHAPUZ, António. "A formação inicial de professores na encruzilhada do processo de Bolonha”. Revista de Educação, 2002, v. XI, n. 1, pp. 31-6.

CALDEIRA, Anna Maria Salgueiro. "A apropriação e construção do saber docente e a prática cotidiana”. Cadernos de Pesquisa, 1995, n. 95, pp. 5-12.

—. "Fragmentos da história de vida de uma professora". Educação em Revista, 2000, n. 32, pp. 122-3.

CAMPOS, Bártolo Paiva. "As ciências da educação em Portugal”. Inovação, 1993, v. 6, pp. 11-28.

—_. "Desenvolvimento recente das ciências da educação em Portugal". Actas do II Congresso da Sociedade Portuguesa de Ciências da Educação - Ciências da Educação: Investigação e Acção. Braga, v. I, pp. 13-6, 1995a.

- Formação de professores em Portugal. Lisboa: Instituto de Inovação Educacional, 1995 b. . Questôes de política educativa. Porto: Ediçōes Asa, 1999.

CANÁRIO, Rui. "Mudar as escolas: o papel da formação e da pesquisa". Inovação, 1991, v. 4, n. 1, pp.77-92.

CANELHAS, Sara e NOGUEIRA, Paulo. "Ensaio(s) de autoformação por uma escrita colectiva”. Educação, Sociedade e Culturas, 2004, v. 22, pp. 87-107.

CARBONNEAU, M. E HÉTU, Jean-Claude. "Formation pratique des enseignants et naissance d'une intelligence professionnelle". In PAQUAY, Léopold et al. (eds.). Former des enseignants professionnels: quelles stratégies? Quelles copétences? 3 ed. Bruxelas: De Boeck Université, 2001, pp. 77-96.

CARINO, Jonaedson. "A biografia e sua instrumentalidade educativa”. Educação e Sociedade, 1999, v. 67, pp. 153-81.

CARLOS, José A. "O desenvolvimento do professor numa perspectiva de formação permanente”. Inovação, 1991 , v. 4, p. 1.

CARRÉ, Philippe. "L'autodirection en formation: contribution à une analyse ternaire de l'autoformation". Education Permanente, 1995, v.1, n. 122, pp. 221-32.

_ et al. "Editorial". Education Permanente, 1995, v. 1, p. 122.

CASTRO, Magali de. "Reflexôes sobre a profissão docente: antigas professoras falam sobre o passado e o presente da professora primária”. Anais da XXVIII Reunião Anual da Associação Nacional de Pesquisa e Pós-Graduação em Educação. Caxambu, 2005. 
CATANI, Denice Bárbara. "Distâncias, vizinhanças, relações: comentários sobre os estudos sócio-histórico-comparados em educação”. In NÓVOA, António e SCHRIEWER, Jürgen (orgs.). A difusão mundial da escola. Lisboa: Educa, 2000.

— e VICENTINI, Paula Perin. "'Minha vida daria um romance': lembranças e esquecimentos, trabalho e profissão nas autobiografias de professores”. In MIGNOT, Ana Chrystina Venancio e CUNHA, Maria Teresa Santos (orgs.). Práticas de memória docente. São Paulo: Cortez, 2003.

CATANI, Denice Bárbara et al. (orgs.). Docência, memória e gênero. São Paulo: Escrituras, 1997.

CATANI, Denice Bárbara et al. “'O amor dos começos': por uma história das relações com a escola”. Cadernos de Pesquisa, 2000, v. 111, pp. 151-71.

CAVACO, Maria Helena. "O ofício do professor: o tempo e as mudanças". In NÓVOA, António (org.). Profissão professor. 2 ed. Porto: Porto, 1995, pp. 7-34.

CERTEAU, Michel. “A operação histórica”. In LE GOFF, Jacques e NORA, Pierre. História: novos problemas. 2 ed. Rio de Janeiro: Francisco Alves, 1979.

CHAIX, Marie-Laure. "L'alternance enseignement-travail comme lieu d'observation privilégié des processus de construction identitaire". Education Permanente, 1996, v. 3, pp. 103-15, 128.

CHARTIER, Roger. A história cultural. Entre práticas e representaçôes. Lisboa: Difel, 1990.

CHAVES, Idália Sá. "Formação de professores: modelos de Referência na Universidade de Aveiro". Revista de Educação, 2002, v. XI, p. 1, pp. 150-3.

CHENÉ, Adèle. "A narrativa de formação e a formação de formadores". In NÓVOA, António e FINGER, Matthias. O método (auto)biográfico e a formação. Lisboa: Ministério da Saúde, 1988.

CIFALI, Mireille. "Démarche clinique, formation et écriture”. In PAQUAY, Léopold et al. (orgs.). Former des enseignants professionnels: Quelles stratégies? Quelles copétences? 3 ed. Bruxelas: De Boeck Université, 2001, pp. 119-36.

CONDE, Idalina. "Falar da vida”. Sociologia - Problemas e Práticas, 1993, v. 14, pp. 199-222.

CONHEN, D. e MANION, F. Métodos de investigación en educación. Madri: Muralla Ediciones, 1992.

CONNELLY, F. Michael e CLANDININ, D. Jean. Teachers as curriculum planners: narratives of experience. Teachers College: Columbia University, 1988.

CONTRERAS, José. A autonomia de professores. São Paulo: Cortez, 2002.

CORREIA, José Alberto. "Mudança educacional e formação: venturas e desventuras do processo social da produção da identidade profissional dos professores". Inovação, 1991, v. 4, n. 1, pp. 149-65.

CORTESÃO, Irene. "Reflexôes sobre histórias de vida: no cruzamento de três olhares sobre a escola”. Educação, Sociedade e Culturas, 1996, v. 5, pp. 175-207.

CORTESÃO, Luísa. "Formação: algumas expectativas e limites - reflexōes críticas". Inovação, 1991, v. 4, n. 1, pp. 93-9.

- - Ser professor: um ofício em risco de extinção: reflexões sobre práticas educativas face à diversidade, no limiar do século XXI. Porto: Afrontamento, 2000.

— e STOER, Stephen R. "Acerca do trabalho do professor: da tradução à produção do conhecimento no processo educativo”. Revista Brasileira de Educação, 1999, v. 11, pp. 33-45. 
COSME, Ariana. "Da reinvenção do modo de educação escolar à reinvenção da profissão de professor: contributo para um debate acerca do mal-estar docente”. Educação, Sociedade e Culturas, s. d., v. 22, pp. 183-213.

COSTA, Áurea de Carvalho. "Quatro questōes sobre a noção de competências na formação de professores: o caso brasileiro". Revista de Educação, 2004, v. XII, pp. 2, 95-106.

COUCEIRO, Maria do Loureto Paiva. Processo de autoformação: uma produção singular de si próprio. Monte de Caparica: Universidade Nova de Lisboa, 1992.

— . "A prática das histórias de vida em formação: um processo de investigação e de formação". Actas do Colóquio da Sociedade Portuguesa de Ciências da Educação. Estado Actual da Investigação e Formação. Porto: Afrontamento, 1994.

—. "Autoformation et conscientisation du sujet féminin". Education Permanente, 1995a, v. 1, n. 122, pp. 53-62.

—_. "Experiência e autoformação". Actas do II Congresso da Sociedade Portuguesa de Ciências da Educação - Ciências da Educação: Investigação e Aç̧ão. Braga, v. II, pp. 333-7, 1995b. . "Autoformação e transformação das práticas profissionais dos professores". Revista de Educação, 1998, v. VII, n. 2, pp. 53-62.

—. "Seminário - histórias de vida". In MALPIQUE, Manuela. Histórias de vida. Porto: Campo das Letras, 2002a, pp.151-3.

—. "O porquê e para que do uso das histórias de vida". In MALPIQUE, Manuela. Histórias de vida. Porto: Campo das Letras, pp. 155-60, 2002b.

COURTOIS, Bernadette. "L'expérience formatrice: entre auto et écoformation". Education Permanente, 1995 , v. 1, n. 122, pp. 31-45.

CRUZ, Léa. Linguas cortadas: medo e silenciamento no trabalho do professor. Niterói: EDUFF/ Intertexto/São Paulo: Xamã, 2005.

CUNHA, António Camilo. "A socialização dos professores e o ciclo de vida profissional". Educação em Revista, 2003, v. 4, pp. 51-64.

CUNHA, Maria Isabel. O bom professor e sua prática. Campinas, SP: Papirus, 1994.

—. "Ensino com pesquisa: a prática do professor universitário". Cadernos de Pesquisa, 1996, v. 97, pp. 31-46.

- "Conta-me agora! As narrativas como alternativas pedagógicas na pesquisa e no ensino". Revista da Faculdade de Educação da USP, 2001, v. 23, n. 1-2, pp. 185-95.

CUNHA, Maria Tereza S. "Biblioteca das moças: contos de fada ou contos de vida?”. Cadernos de Pesquisa, 1993, v. 85, pp. 54-62.

CURIE, Jacques. "Parcours professionnels et interdépendances des domaines de vie". Education Permanente, 2002, v. 1, pp. 23-32, 150.

DA ROS, Sílvia Zanatta et al. "Fala pedagogia: um estudo sobre o perfil acadêmico dos estudantes e suas opiniōes sobre este curso da UFSC". Anais da XXIV Reunião Anual da Associação Nacional de Pesquisa e Pós-Graduação em Educação. Caxambu, 2001.

DAVALLON, Jean. A imagem, uma arte de memória? Comunicação apresentada no Simpósio Caminhos do Pensamento: Horizontes da Memória. Rio de Janeiro, 1999.

DECOMPS, B. e MALGLAIVE, G. "Comment asseoir le concept d'université professionnelle?”. In BARBIER, Jean-Marie (org.). Savoirs theóriques et savoirs d'action. Paris: Presses Universitaires de France, 1996, pp. 57-72. 
DELFORCE, Bernard e HÉDOUX, Martine. "Représentations de la langue et représentations du savoir dans des formations à l'écrit: pour une pédagogie des ruptures". Education Permanente, 1990, n. 102, pp. 51-61.

DELGADO, Marcia Cristina. Os santinhos de Soledade, os acervos pessoais como fontes. Disponível em http://www.educaoonline.pro.br. Acesso em abr. 2006.

DEMARTINI, Zeila de Britro Fabri. "Velhos mestres das novas escolas: um estudo das memórias de professores da Primeira República em São Paulo”. Cadernos CERU, 1984, v. 19, pp. 197-205.

— e ANTUNES, Fátima Ferreira. "Magistério primário: profissão feminina, carreira masculina”. Cadernos de Pesquisa, 1993, v. 86, pp. 5-14.

DEMARTINI, Zeila de Britro Fabri et al. "Os alunos e o ensino na República Velha através das memórias de velhos professores”. Cadernos de Pesquisa, 1985, v. 52, pp. 61-71.

DIAS, Fátima Rezende Naves e CICILLINI, Graça Aparecida. "Pela narrativa dialógica... Os movimentos de constituição de formação de professores a partir do interior da escola”. Anais da XXV Reunião Anual da Associação Nacional de Pesquisa e Pós-Graduação em Educação. Caxambu, 2002.

DIAS, José Ribeiro. "Trinta anos de formação de professores em Portugal”. Revista de Educação, 2002, v. XI, n. 1, pp. 153-6.

DOMINICÉ, Pierre. "A biografia educativa: instrumento de investigação para a educação de adultos”. In NÓVOA, António e FINGER, Matthias (orgs.). O método (auto)biográfico e a formação. Lisboa: Ministério da Saúde, 1988a.

—_. "O processo de formação e alguns dos seus componentes relacionais". In NÓVOA, António e FINGER, Matthias (orgs.). O método (auto)biográfico e a formação. Lisboa: Ministério da Saúde, 1988b.

—. "O que a vida lhes ensinou”. In NÓVOA, António e FINGER, Matthias (orgs.). O método (auto)biográfico e a formação. Lisboa: Ministério da Saúde, 1988c.

- La formation enjeu de l'evaluation. 3 ed. Berne, Frankfurt: Peter Lang, 1985, pp. 1-67. . "La formation adulte en tant que régulateur des itinéraires de vie". Education Permanente, 1999, v. 1, n. 138, pp. 143-51.

- Learning from our lives: using educational biographies with adults. São Francisco: JosseyBass, 2000.

_ et al. "Que faire des histoires de vie ? Retour sur quinze ans de pratiques". Education Permanente, 2000a, v. 1, n. 142, pp. 217-39.

-. "Donner une place au sensible pour penser la formation". Education Permanente, 2000b, v. 1, n. 142, pp. 95-104.

DUBAR, Claude. "L'enjeu des expériences de formation innovante en entreprise: un nouveau processus de socialisation professionnelle”. Education Permanente, 1990, n. 104, pp. 51-5. - "Usages sociaux et sociologiques de la notion d'identité". Education Permanente, 1996, v. 3, n. 128 , pp. 37-44.

—. "Trajetórias sociais e formas identitárias: alguns esclarecimentos conceituais e metodológicos”. Educação e Sociedade, 1998, v. 62, pp. 13-30.

DUMAZEDIER, Joffre. "Aides à l'autoformation: un fait social d'aujourd'hui". Education Permanente, 1995 , v. 1, n. 122, pp. 243-56. 
ELLIOTT, John. “Introduction”. In --- (org.). Reconstructing teacher education. Londres: The Falmer Press, 1993, pp. 1-12.

—. "The assault on rationalism and the emergence of the social market perspectives". In --- (org.). Reconstructing teacher education. Londres: The Falmer Press, pp. 20-30, 1993. . "Three perspectives on coherence and continuity in teacher education". In ELLIOTT, John (org.). Reconstructing teacher education. Londres: The Falmer Press, 1993, pp. 15-9.

ESTADES, Jacqueline e JACOBI, Daniel. "Ecrire un mémoire: prescrive ou guider?”. Education Permanente, 1990, v. 102, pp. 63-75.

ESTEVÃO, Carlos Vilar e AFONSO, Almerindo Janela. "Contextos organizacionais e construção da identidade profissional: profissionalidade docente nos ensinos público e privado”. Inovação, 1991, v. 4, n .2-3, pp. 155-65.

ESTEVES, Manuela. "Alguns contributos para a discussão sobre a formação contínua de professores”. Inovação, 1991, v. 4, n. 1, pp. 101-11.

ESTRELA, Maria Teresa. "Realidades e perspectivas da formação contínua de professores". CEEP, Universidade do Minho, 2001, v. 14, n. 1, pp. 27-48.

—. "Modelos de formação de professores e seus pressupostos conceptuais". Revista de Educação, 2002, v. XI, n. 1, pp. 17-29.

FABRE, Michel. "La formation comme régime nocturne: raison narrative et formation". Education Permanente, 1995, v. 1, n. 122, pp. 179-89.

FELGUEIRAS, Margarida Louro. "A criação do Museu da Escola Primária no Porto: uma experiência de constituição de fontes para a história da educação primária em Portugal”. Revista de Educação, 2000, v. IX, n. 2, pp. 49-58.

FERNANDES, Rogério. "Génese e consolidação do sistema educativo nacional (1820-1910)". Revista de Educação, 1998, v. 1, pp. 35-48.

__. "Dois anos de trabalho no ensino básico (1974-1976)". Educação, Sociedade e Culturas, 1999, n. 11, pp. 9-27.

FERNANDEZ, Elias Blanco e PACHECO, José Augusto. "A problemática de práticas na formação inicial integrada de professores". Revista Portuguesa de Educação, Universidade do Minho, 1990, v. 4, n. 3, pp. 63-71.

FERRAROTTI, Franco. Histoire et histoires de vie: la méthode biographique dans les sciences sociales. 2 ed. Paris: Méridiens Klincksieck, 1990.

FERREIRA, Aurélio Buarque de Holanda. Novo Aurélio século XXI: o dicionário da língua portuguesa. 3 ed. Rio de Janeiro: Nova Fronteira, 1999.

FERREIRA, Marieta de Moraes e AMADO, Janaina (orgs.). Usos e abusos da história oral. Rio de Janeiro: FGV, 2001.

FIGUEIRA, Maria de Lourdes Rodrigues Cardoso. Fragmentos da memória: reflexôes sobre o quotidiano do professor. Lisboa: Instituto de Inovação Educacional, 1996.

FINGER, Mathias. "As implicações socioepistemológicas do método biográfico". In NÓVOA, António e FINGER, Matthias (orgs.). O método (auto)biográfico e a formação. Lisboa: Ministério da Saúde, 1988.

FLORES, Maria Assunção. "Os professores em início de carreira e o seu processo de mudança: influências e percursos". Revista de Educação, 2004, v. 2, pp. 107-17.

FOND-HARMANT, Laurence. "Approche biographique et retour aux études". Education Permanente, 1995, v. 4, n. 125, pp. 1-26. 
FONTANA, Roseli A. Cação. Como nos tornamos professoras? Belo Horizonte: Autêntica, 2005. FONTOURA, Maria Madalena. "Fico ou vou-me embora?". In NÓVOA, António (org.). Vidas de professores. Porto: Porto, 1992.

FORTES, Maria de Fátima Ansaloni. "Escola rural mineira: observaçōes produzidas a partir de depoimentos de antigas professoras". Educação em Revista, 1994, n. 18- 19, pp. 80-92. FOX, Mem. Guilherme Augusto Araújo Fernandes. São Paulo: Brinque-Book, 1995.

FRANCEQUIN, Ginette e BLANCHE, Anasthasia. "Histoires de vie et démarches d'orientation". Education Permanente, 2000, v. 1, n. 142, pp.185-94.

FRANCO, Maria Amélia Santoro. "História de vida: uma abordagem emancipatória aliando pesquisa e formação de professor reflexivo". Anais da XXIII Reunião Anual da Associação Nacional de Pesquisa e Pós-Graduação em Educação. Caxambu, 2000.

FRANCO, Maria Ciavatta. "Quando nós somos o outro: questōes teórico-metodológicas sobre os estudos comparados”. Educação e Sociedade, 2000, v. 21, n. 72, pp. 197-230.

- O mundo do trabalho em imagens: a fotografia como fonte histórica. Rio de Janeiro: DP\&A, 2002.

FRANÇOIS, Etienne. "A fecundidade da história oral”. In FERREIRA, Marieta de Moraes e AMADO, Janaina (orgs.). Usos e abusos da história oral. Rio de Janeiro: FGV, 2001.

FREIRE, Paulo. Ação cultural para liberdade. 8 ed. Rio de Janeiro: Paz e Terra, 1982.

—. Pedagogia do oprimido. 13. ed. Rio de Janeiro: Paz e Terra, 1983.

- Medo e ousadia: o cotidiano do professor. Rio de Janeiro: Paz e Terra, 1986.

- Pedagogia da esperança: um reencontro com a pedagogia do oprimido. Rio de Janeiro: Paz e Terra, 1992.

—. Professora sim, tia não. 5 ed. São Paulo: Olho d'Água, 1994.

FUSULIER, Bernard e MAROY, Christian. "Formation par le travail et reconstruction identitaire”. Education Permanente, 1996, v. 3, n. 128, pp. 117-33.

GAGNEBIN, Jeanne Marie. "Prefácio”. In BENJAMIN, Walter. Magia e técnica, arte e politica. São Paulo: Brasiliense, 1993.

- História e narração em Walter Benjamin. São Paulo: Perspectiva, 1994.

GAGNEPAIN, J. J. e ANDRÉ, J. C. "Les savoirs de l'ingénieur". In BARBIER, Jean-Marie (org.). Savoirs theóriques et savoirs d'action. Paris: Presses Universitaires de France, 1996, pp. 91-100.

GALVANI, Pascal. "Le blason, éléments pour une méthodologie exploratoire de l'autoformation”. Education Permanente, 1995, v. 1, n. 122, pp. 97-111.

GALVĀO, Cecília. "Da formação à prática profissional”. Inovação, 2000, v. 13, n. 2-3, pp. 57-82.

GARCIA, Carlos Marcelo. "A formação de professores: novas perspectivas baseadas na investigação sobre o pensamento do professor". In NÓVOA, António (org.). Os professores e sua formação. Lisboa: Publicações Dom Quixote, 1992.

GASPARELLO, Vânia Medeiros. "Subjetividade e formação de professores: algumas reflexões a partir da psicologia analítica”. E-Curriculum, 2006, v. 2, n. 3. Disponível em http:// www.pucsp.br/ecurriculum. Acesso em 28 mai. 2008.

GATTI, Bernadete Angelina. "Os professores e suas identidades: o desenvolvimento da heterogeneidade”. Cadernos de Pesquisa, 1996, v. 98, pp. 85-90. 
- et al. "Características de professores(as) de $1^{\circ}$ grau no Brasil: perfil e expectativas". Educação \& Sociedade, 1994, v. 48, pp. 248-60.

GHEDIN, Evandro Luiz. "Professor-reflexivo: da alienação da técnica à autonomia da crítica”. Anais da XXIV Reunião Anual da Associação Nacional de Pesquisa e Pós-Graduação em Educação. Caxambu, 2001.

GHIGLIONE, Rodolphe e MATALON, Benjamin. O inquérito: teoria e prática. Oeiras: Celta, 2001, pp. 177-228.

GINZBURG, Carlo. Mitos, emblemas e sinais. São Paulo: Companhia das Letras, 1989.

GÓMEZ, Angel Pérez. "O pensamento prático do professor: a formação do professor como profissional reflexivo”. In NÓVOA, António (org.). Os professores e sua formação. Lisboa: Publicações Dom Quixote, 1992.

GONÇALVES, José Alberto M. "A carreira das professoras do ensino primário”. In NÓVOA, António (org.). Vidas de professores. Porto: Porto, 1992.

GONÇALVES, Óscar F. e ALVES, José F. “Desafios do professor numa escola pós-moderna: a construção narrativa da existência”. Colóquio Educação e Sociedade, n. 10, pp. 137-51, 1995.

GOODSON, Ivor F. "Dar voz ao professor: as histórias de vida dos professores e o seu desenvolvimento profissional”. In NÓVOA, António (org.). Vidas de professores. Porto: Porto, 1992.

GRINÉ, Maria de Jesus. Reforma educativa: história de uma vivência (1º ciclo). Coimbra: Escola Superior de Educação de Coimbra, 1992.

GUARNIERI, Maria Regina et al. "Identificando mudanças na atuação docente a partir da prática de elaboração de registros pelos professores". Anais da XXIV Reunião Anual da Associação Nacional de Pesquisa e Pós-Graduação em Educação. Caxambu, 2001.

HALBWACHS, Maurice. A memória coletiva. São Paulo: Vértice, 1990.

HOLLY, Mary Louise. "Investigando a vida profissional dos professores: diários biográficos". In NÓVOA, António (org.). Vidas de professores. Porto: Porto, 1992.

HORTALE, Virgínia Alonso e MORA, José-Ginés. "Tendências das reformas da educação superior na Europa no contexto do processo de Bolonha”. Educação e Sociedade Especial, out. 2004, v. 25, n. 88, pp. 937-60.

HUBERMAN, Michael. “O ciclo de vida profissional dos professores”. In: NÓVOA, António (org.). Vidas de professores. Porto: Porto, 1992.

JESUS, Saul Neves e ABREU, Manuel Viegas. "Projecto profissional e expectativas de realização dos professores - um estudo exploratório". Inovação, 1994, n. 7, pp. 215-21.

JESUS, Saul Neves et al. "Uma abordagem sociopolítica do mal-estar docente". Revista Portuguesa de Pedagogia, 1996, ano XXX, n. 1, pp. 51-64.

JOSSO, Marie-Christine. "Da formação do sujeito... ao sujeito da formação". In NÓVOA, António e FINGER, Matthias (orgs.). O método (auto)biográfico e a formação. Lisboa: Ministério da Saúde, 1988a.

- "Cheminer avec: interrogations et défis posés par la recherche d'un art de la convivance en histoire de vie”. In PINEAU, Gaston (org.). Accompagnements et histoire de vie. Paris: LHarmattan, 1988b.

. Cheminer vers soi. Suisse: Editions l'Age d'Homme, 1991. 
. "Convergências e interdisciplinaridade da investigação em formação". Actas do Colóquio Estado Actual da Investigação e Formação. Porto: Sociedade Portuguesa de Ciências da Educação/Afrontamento, 1994, pp. 69-84.

—. Experiências de vida e formação. Lisboa: Educa, 2002a.

—. "Revaloriser l'imaginaire dans la formation pour inventer la mutation culturelle". In MALPIQUE, Manuela. Histórias de vida. Porto: Campo das Letras, 2002b.

JOUTARD, Philippe. "História oral: balanço da metodologia e da produção dos últimos 25 anos". In FERREIRA, Marieta de Moraes e AMADO, Janaina (orgs.). Usos e abusos da história oral. Rio de Janeiro: FGV, 2001.

KENSKI, Vani Moreira. "Memória e ensino”. Cadernos de Pesquisa, 1994, v. 90, pp. 45-51. . "Sobre o conceito de memória”. In FAZENDA, Ivani (org.). A pesquisa em educação e as transformaçôes do conhecimento. São Paulo: Papirus, 1995.

—. "Memórias e formação de professores, interfaces com as novas tecnologias de comunicação". In: CATANI, Denice Bárbara et al. Docência, memória e gênero. São Paulo: Escrituras, 1997.

KRAMER, Sonia. "A formação do professor como leitor e construtor do saber". In MOREIRA, Antonio Flávio Barbosa (org.). Conhecimento e formação do professor. Campinas, SP: Papirus, 1994.

—_. "Dando vez ao mestre". Presença Pedagógica, jul.-ago. 1995, pp. 5-21. . "Leitura e escrita de professores". Revista Brasileira de Educação, 1998, n. 7, pp. 19-41.

LACERDA, Lilian Maria. "Rastreando memórias femininas: reconstruindo histórias de leitoras". Educação em Revista, 2001, n. 33, pp. 67-90.

LAINÉ, Alex. "L'histoire de vie, un processus de 'métaformation". Education Permanente, 2000, v. 1, n. 142, pp. 29-43.

LANI-BYLE, Martine. "Histoire de vie et transmission intergénérationnelle". Education Permanente, 2000, v. 1, n. 142, pp. 85-93.

LAPO, Flavinês Rebolo e BUENO, Belmira Oliveira. "Professores, desencanto com a profissão e abandono do magistério". Cadernos de Pesquisa, 2003, n. 118, pp. 65-88.

LAZEGA, Emmanuel. "Introduction". In FERRAROTTI, Franco. Histoire et histoires de vie: la méthode biographique dans les sciences sociales. 2 ed. Paris: Méridiens Klincksieck, 1990.

LE GRAND, Jean-Louis. "Considérations critiques sur les modeles maieutiques". In PINEAU, Gaston (org.). Accompagnements et histoire de vie. Paris: L'Harmattan, 1998.

LE MEUR, Georges. "La praxéogogie: une néoautodidaxia". Education Permanente, 1995, v. 1, n. 122, pp.113-24.

LE MOIGNE, Jean-Louis. "Paradoxale autoformation, merveilleuse et pourtant intelligible". Education Permanente, 1995, v. 1, n. 122, pp. 201-12.

LEAL, Maria Cristina. "Retratos da educação brasileira: contraste entre a educação republicana imaginada e realizada”. In: --- e PIMENTEL, Marília Araújo Lima (orgs.). História e memória da escola nova. São Paulo: Edições Loyola, 2003.

LEBERT, Georges. "Automonie et autoréférence en éducation: quelques points de repère". Education Permanente, 1995, v. 1, n. 122, pp. 191-200.

LEBLOND, Fabienne. "Relire et relier nos souvenirs: l'accompagnement intergénérationnel". Education Permanente, 2002, v. 4, n. 153, pp. 57-68. 
LEJEUNE, Philippe. "Definir autobiografia". In MOURÃO, Paula (org.). Autobiografia, autorrepresentação. Lisboa: Edições Colibri, 2003.

LELIS, Isabel. A formação da professora primária: da denúncia ao anúncio. 2 ed. São Paulo: Cortez, 1993.

—_. "Profissão docente: uma rede de histórias". Revista Brasileira de Educação, 2001, n. 17, pp. 40-9.

LERBET, Georges. "Recherche-action, écriture et formation d'adultes". Education Permanente, 1990, n. 102, pp. 143-7.

LEWIS, Óscar. Os filhos de Sánchez. Portugal: Moraes Editores, 1961.

LHOTELLIER, Alexandre. "Action, praxéologie et autoformation: un fait social d'aujourd'hui”. Education Permanente, 1995, v. 1, n. 122, pp. 243-56.

LIBÂNEO, José Carlos. "Reflexividade e formação de professores: outra oscilação do pensamento pedagógico brasileiro?”. In PIMENTA, S. G. e GHEDIN, Evandro (org.). Professor reflexivo no Brasil: gênese e crítica de um conceito. São Paulo: Cortez, 2002, pp. 53-79.

LINHARES, Célia. A crise do político na educação - a imposição da estratégia: espaço de servidão versus a emancipação dos sujeitos históricos na construção da ética (tese para concurso de professor titular). UFF, 1994.

—. Sujeito histórico e memória cultural: contradiçôes e desafios. Niterói, RJ: UFF, 1995a.

- "Comparação dos sistemas educativos: extravios e promessas para o novo século". Anais do II Congresso da Sociedade Portuguesa de Ciências da Educação - Ciências da Educação: Investigação e Acção. Braga, 1995b.

- A invenção da escola pública: o legado das vozes e das letras na formação dos professores. Niterói, RJ: UFF, 1996.

—. Experiências instituintes em escolas públicas: memórias e projetos para a formação de professores. Projeto de pesquisa, CNPq. Rio de Janeiro, 2000.

- Relatório resumido. Relatório de pesquisa, CNPq. Rio de Janeiro, 2001.

—_. "Memórias e narrações como leitura e releitura do mundo em Paulo Freire". In --- e TRINDADE, Maria Nazaret. Compartilhando o mundo com Paulo Freire. São Paulo: Cortez/Instituto Paulo Freire, 2003.

—. Relatório resumido. Relatório de Pesquisa, CNPq. Rio de Janeiro, 2005a.

- Experiências instituintes em escolas públicas e formação docente: Brasil e Portugal. Niterói, RJ: UFF, 2005b.

—. Enluarar amnésias, abrir atalhos para educar. Niterói, RJ: UFF, 2005c.

—. "Experiências instituintes na educação pública? Alguns porquês dessa busca". Revista de Educação Pública, 2007, v. 16, n. 31, pp. 139-60.

—. "Conhecimentos docentes e suas relações poéticas com uma democracia cognitiva". Educação: Temas e Problemas, Universidade de Évora, 2009, ano 4, n. 7, pp. 143-55.

— e NUNES, Clarice. Trajetórias de magistério: memórias e lutas pela reinvenção da escola pública. Rio de Janeiro: Quartet, 2000.

LOPES, Amélia. "Professores e identidade: condiçōes piscossociais de mudança". Actas do Colóquio da Sociedade Portuguesa de Ciências da Educação. Estado Actual da Investigação e Formação. Porto: Afrontamento, 1994.

- Libertar o desejo, resgatar a inovação: a construção de identidades profissionais docentes. Lisboa: Instituto de Inovação Educacional, 2001a. 
- Professoras e identidade: um estudo sobre a identidade social de professoras portuguesas. Porto: Asa Editores, 2001b.

—_. "Construção de identidades docentes e selves profissionais: um estudo sobre a mudança pessoal nos professores”. Revista de Educação, 2002, v. XI, v. 2, pp. 35-52.

— e RIBEIRO, Agostinho. "Identidades profissionais no $1^{\circ}$ ciclo do ensino básico: as fontes do nosso (des)contentamento". Educação, Sociedade e Culturas, 2000a, v. 13, pp. 43-58.

—. "A construção de identidades profissionais docentes: identidade situada e mudança identitária em docentes do $1^{\circ}$ ciclo do ensino básico”. Inovação, 2000b, v. 13, n. 2-3, pp. 39-55.

LOPES, Eliane Marta Teixeira. Perspectivas históricas da educação. São Paulo: Ática, 1989.

LOURO, Guacyra Lopes. "Gênero e magistério: identidade, história e representação". In CATANI, D. B. (et al.). Docência, memória e gênero. São Paulo: Escrituras, 1997.

LUDKE, Menga. "O professor, seu saber e sua pesquisa”. Educação e Sociedade, 2001, v. 74, pp. 77-97.

— e BOING, Luiz Alberto. "Caminhos da profissão e da profissionalide docentes". Educação e Sociedade, 2004, v. 89, pp. 1159-80.

LUWISCH, Feema Elbaz. "O ensino e a identidade narrativa”. Revista de Educação, 2002, v. XI, n. 2, pp. 21-33.

MALPIQUE, Manuela. Histórias de vida. Porto: Campo das Letras, 2002.

MARCELO, Carlos. "Pesquisa sobre a formação de professores: o conhecimento sobre aprender a ensinar". Revista Brasileira de Educação, 1998, n. 9, pp. 51-75.

MARMOZ, Louis. "O professor e seus espelhos". Colóquio Educação e Sociedade, 1993, n. 4, pp. 13-40.

MARQUES, Maria Emilia Ricardo. “De la reproduction des savoirs à l'autoformation”. Education Permanente, 1995, v. 1, n. 122, pp5. 47-52.

MARTINS, Ernesto Candeias. "A formação permanente dos professores dentro do sistema educativo". Inovação, 1991, v. 4, n. 1, pp. 113-33.

MATTA, Hélida Gmeiner. Crônicas de uma trajetória docente. Niterói: Intertexto, 2008.

MATURANA, Humberto. Emoções e linguagem na educação e na política. Belo Horizonte: Ed. UFMG, 2002.

— et al. Cérebro, linguagem e a origem das funçôes mentais humanas. Santiago: Universidade do Chile, s. d.

MEHAUT, Philippe. "Les temps de l'entreprise et la formation". Education Permanente, 1990, n. 104, pp. 57-64.

MEIER, Patrick e RAMBAUD, Marie-Hélène. "Parler, écouter, écrire... De quelques effets sensibles de l'atelier d'écriture”. Education Permanente, 1999, pp. 207-15 (suplemento). MEIRIEU, Philippe. Enseigner, scénario pour un métier nouveau. Paris: ESF, 1989.

MENDONÇA, Ana Waleska P. C. "Universidade e formação de professores: uma perspectiva histórica”. Cadernos de Pesquisa, 1994, v. 90, pp. 36-44.

MIALARET, G. "Savoirs théoriques, savoirs scientifiques et savoirs d'action en education". In BARBIER, Jean-Marie (org.). Savoirs theóriques et savoirs d'action. Paris: Presses Universitaires de France, pp. 161-88, 1996. 
MIGNOT, Ana Chrystina Venancio. "Em busca do tempo vivido: autobiografias de professoras”. In --- e CUNHA, Maria Teresa Santos (orgs.). Práticas de memória docente. São Paulo: Cortez, 2003.

MIRANDA, Guilhermina Lobato. "Formar professores - apontamentos críticos”. Revista Portuguesa de Educação, 1992, v. 5, n. 2, pp. 137-47.

MIRANDA, Maria Salete de. "Docência e devir: com a palavra, a professora...". Anais da XXVIII Reunião Anual da Associação Nacional de Pesquisa e Pós-Graduação em Educação. Caxambu, 2005.

MLÉKUZ, Gérard. "La TSF, le Kini et l'étrange lucarne”. Education Permanente, 1995, v. 1, n. 122 , pp. 131-8.

MOISAN, André. "Autoformation et situations de travail". Education Permanente, 1992, v. 112, pp. 107-13.

—. "Autoformation et organisation apprenante". Education Permanente, 1995, v. 1, p. 122, pp. 15-29.

MOITA, Maria da Conceição. "Percursos de formação e de trans-formação". In NÓVOA, António (org.). Vidas de professores. Porto: Porto, 1992.

MOLINIÉ, Muriel. "Ecrire son histoire pour penser la culture". Education Permanente, 2000, v. 1 , n. 142, pp. 133-46.

MONTEIRO, A. Reis. "Ser professor". Inovação, 2000, v. 13, n. 2-3, pp. 11-37.

MONTEIRO, Filomena Maria de Arruda. "Desenvolvimento profissional da docência: uma experiência de formação". Anais da XXVIII Reunião Anual da Associação Nacional de Pesquisa e Pós-Graduação em Educação. Caxambu, 2005.

MORAIS, Jacqueline de Fatima dos Santos e JESUS, Regina de Fátima. Formação de professoras - percebendo o entrelaçar de fios na construção da identidade docente, 2001. Disponível em http://www.educaoonline.pro.br.

MORANDI, Franc. "Ecriture, formation et représentation: a propos du mémoire professionnel des enseignants”. Education Permanente, 2003, v. 2, n. 155, pp. 79-101.

MORIN, Edgar (org.). O problema epistemológico da complexidade. Mem Martins: Publicações Europa-América, s. d.

— e MOIGNE, Jean-Louis Le. A inteligência da complexidade. São Paulo: Peirópolis, 2000.

MOURÃO, Marcia Souto Maior. Professoras: ditos e escritos, 2002. Disponível em http:// www.educaoonline.pro.br. Acesso em 5 jan. 2006.

MUÑOZ, Juan José Pujadas. El método biográfico: el uso de las historias de vida en ciencias sociales. Madri: Centro de Investigaciones Sociológicas, 1992.

MURCHO, Desidério. A formação continua de professores, 2004. Disponível em http://www. criticanarede.com/ed34.html. Acesso em ago. 2005.

NICO, José Bravo. "A abordagem biográfica”. A relação pedagógica na universidade: "ser-se caloiro” (dissertação). Universidade de Lisboa, 1995.

—. Tornar-se estudante universitário: contributo do conforto académico na definição de uma estratégia curricular de sucesso (tese). Universidade de Évora, 2001.

. "Práticas educativas e aprendizagens formais e informais: encontros entre cidade, escola e formação de professores”. In BRAGANÇA, I. F. S. et al. (orgs.). Vozes da Educação: memórias, histórias e formação de professores. Petrópolis: DP et alii, 2008. 
NIEWIADOMSKI, Christophe. "Histoires de vie et enjeux de 'pouvoir-savoir' avec personnes alcooliques". Education Permanente, 2000, v. 1, n. 142, pp. 169-84.

NORA, Pierre. "Entre memória e história: a problemática dos lugares". Revista de Pesquisa Histórica, São Paulo, 1993, v. 10, pp. 1-178.

NOVAES, Maira Eliana. Professora primária: mestra ou tia? 5 ed. São Paulo: Cortez/Autores Associados, 1992.

NÓVOA, António. Le temps des professeurs: analyse socio-historique de la profession enseignante au Portugal. Coimbra: Instituto Nacional de Investigação Científica/Imprensa de Coimbra, 1987, v. I.

—. "A república e a escola: das intenções generosas ao desengano das realidades". Revista Portuguesa de Educação, 1988a, v. 1, n. 3, pp. 29-60.

—. "O método (auto)biográfico na encruzilhada dos caminhos (e descaminhos) da formação dos adultos”. Revista Portuguesa de Educação, 1988b, Universidade do Minho, v. 1, n. 2, pp. 7-20.

—. Do mestre-escola ao professor do ensino primário: subsídios para a história da profissão docente em Portugal (séculos XVI-XX). Lisboa: Centro de Documentação e Informação, 1989a.

—_. "Inovação e história da educação". Inovação, 1989b, v. 2, n. 1, pp. 22-9.

. "A formação contínua entre a pessoa-professor e a organização-escola". Inovação, 1991, v. 4, n. 1, pp. 63-76.

— (org.). Vidas de professores. Portugal: Porto, 1992a. (org.). Os professores e sua formação. Lisboa: Publicações Dom Quixote, $1992 \mathrm{~b}$. . "A educação nacional". In ROSAS, Fernando (org.). Portugal e o Estado Novo (19301960). Nova História de Portugal. Lisboa: Editorial Presença, 1992c, pp. 454-519, 538-42, v. XII.

— - "A reforma educativa portuguesa: questōes passadas e presentes sobre a formação de professores”. In NÓVOA, A. e POPKEWITZ, T. S. (orgs.). Reformas educativas e formação de professores. Lisboa: Educa, 1992d.

_ (org.). Os professores e as reformas de ensino: na viragem do século (1886-1906). Lisboa: Edições Asa, 1993.

—. Educação portuguesa (1945-1992). Universidade de Lisboa, 1994.

- Modèles d'analyse en éducation comparée: le champ et la carte. Universidade de Lisboa, $1995 \mathrm{a}$.

— (org.). Profissão professor. 2 ed. Porto: Porto, $1995 \mathrm{~b}$.

—. "Pessoas e memórias nas histórias de vida". Educação, Sociedade e Culturas, 1996, n. 5, pp. $175-207$.

—. "Tempos da escola no espaço Portugal-Brasil-Moçambique: dez digressōes sobre um programa de investigação". In --- e SCHRIEWER, Jürgen (orgs.). A difusão mundial da escola. Lisboa: Educa, 2000.

—_. "Eu pedagogo me confesso: diálogos com Rui Grácio”. Inovação, 2001, v. 14, n. 1-2, pp. 9-33.

—_. "Prefácio". In JOSSO, Marie-Christine. Experiências de vida e formação. Lisboa: Educa, 2002.

—. Ainda professores... Lisboa: Biblioteca da Universidade de Lisboa, s. d. 
e FINGER, Matthias (org.). O método (auto)biográfico e a formação. Lisboa: Ministério da Saúde, 1988.

NÓVOA, António et al. Educational knowledge and its circulation: historical and comparative approaches of portuguese-speaking countries. Lisboa: Educa, 2003.

NUNES, Célia Maria Fernandes. "Saberes docentes e formação de professores: um breve panorama da pesquisa brasileira”. Educação e Sociedade, 2001, n. 74, pp. 27-43.

NUNES, Clarice. "A reconstrução da memória: um ensaio sobre as condições sociais da produção do educador". Cadernos de Pesquisa, 1987, n. 61, pp.72-80.

—. "Representações das políticas de formação docente no passado e no presente: questôes para reflexão”. In HEES, Martha P. N. Et al. Memória(s), história(s) e educação: fios e desafios na formação de professores. Rio de Janeiro: Armazém das Letras, 2004.

- Formação de educadores: os desafios do presente. Rio de Janeiro, 2006 (texto não publicado).

- Biografias de educadores gonçalenses: a luta contra a invisibilização e o esquecimento. In BRAGANÇA, I. F. S. Et al. (orgs.). Vozes da educação: memórias, histórias e formação de professores. Petrópolis: DP et Alii, 2007.

OLIVEIRA, Clara Costa. "A autopoièsis e a fundamentação das ciências humanas". Revista de Educação, 1993, v. III, n. 2, pp. 9-22.

OLIVEIRA, José H. Barros. "Satisfação, sentimentos e atribuições dos professores". Revista Portuguesa de Pedagogia, 1999, v. 33, n. 2, pp. 47-59.

OROFIAMMA, Roselyne. "Récits de vie et remaniements identitaires". Education Permanente, 1996, v. 3, n. 128, pp. 165-75.

—_. "Comment le sens vient au récit". Education Permanente, 2000, v. 1, n. 142, pp. 115-42.

— et al. "D’une diversité de pratiques à leurs fondements théoriques". Education Permanente, 2000, v. 1, n. 142, pp. 7-10.

PADÉ, Dominique. "Histoires de vie: un passage possible vers l'insertion et la formation des 'faibles niveaux"'. Education Permanente, 1992, n. 111, pp. 167-73.

PAQUAY, Léopold e WAGNER, Marie-Cécile. "Compétences professionnelles privilégiées dans les stages et en vidéo-formation”. In PAQUAY, Léopold et al. (orgs.). Former des enseignants professionnels: quelles stratégies? Quelles copétences? 3 ed. Bruxelas: De Boeck Université, 2001, pp. 153-80.

PAQUAY, Léopold et al. (orgs.). Former des enseignants professionnels: quelles stratégies? Quelles copétences? 3 ed. Bruxelas: De Boeck Université, 2001.

PAQUAY, Léopold et al. In PAQUAY, Léopold et al. (orgs.). Former des enseignants professionnels: quelles stratégies? Quelles copétences? 3 ed. Bruxelas: De Boeck Université, 2001, pp. 13-26.

PASSEGGI, Maria da Conceição. "A formação do formador na abordagem autobiográfica. A experiência dos memoriais de formação". In SOUZA, Elizeu Clementino de e ABRAHĀO, Maria Conceição Menna Barreto (orgs.). Tempos, narrativas e ficçôes: a invenção de si. Porto Alegre: EdiPUCRS/Salvador: EdUNEB, 2006.

PENIN, Sonia Teresinha de Sousa. "A professora e a construção do conhecimento sobre o ensino". Cadernos de Pesquisa, 1995, n. 92, pp. 5-15.

PÉPIN, Elsa e GAREL, Philippe. "Histoire de vie collective ouvrière, journal à trois voix". Education Permanente, 2000, v. 1, n. 142, pp. 195-212. 
PEREIRA, Gilson R. de M. e ANDRADE, Maria da Conceição Lima. "Lucro de ação: um exame das condiçôes de possibilidade do magistério oficial”. Revista Brasileira de Estudos Pedagógicos, 2006, n. 215, pp. 9-16.

PEREIRA, Miguel Baptista. "Introdução". In RICOUER, Paul. A metáfora viva. Porto: Rés, 1983.

PÉREZ, Carmen Lúcia Vidal. "O lugar da memória e a memória do lugar na formação de professores: a reinvenção da escola como uma comunidade investigativa”. Anais da XXVI Reunião Anual da Associação Nacional de Pesquisa e Pós-Graduação em Educação. Caxambu, 2003a.

—. Professoras alfabetizadoras: histórias plurais, práticas singulares. Rio de Janeiro: DP\&A, 2003b.

PERRENOUD, Philippe. La formation des enseignants: entre théorie et pratique. L'Harmattan: Paris, 1994.

—. Développer la pratique réflexive das le métier d'enseignant. Paris : ESF, 2001a.

. "e travail sur l'habitus dans la formation des enseignants. Analyse des pratiques et prise de conscience". In Former des enseignants professionnels: quelles stratégies? Quelles copétences? 3 ed. Bruxelas: De Boeck Université, 2001b, pp. 181-208.

PIMENTA, Selma Garrido. "Apresentação”. In CONTRERAS, José. A autonomia de professores. São Paulo: Cortez, 2002a, pp. 11-22.

—. "Professor reflexivo: historicidade do conceito". In PIMENTA, S. G. e GHEDIN, Evandro (orgs.). Professor reflexivo no Brasil: gênese e crítica de um conceito. São Paulo: Cortez, 2002b, pp. 17-52.

_ et al. "A pesquisa colaborativa na escola como abordagem facilitadora para o desenvolvimento da profissão do professor”. In ALDA, Junqueira Marim (org.). Educação continuada: reflexões, alternativas. Campinas: Papirus, 2000, pp. 89-112.

PINEAU, Gaston (org.). "A autoformação no decurso da vida: entre hetero e a ecoformação”. In: NÓVOA, António e FINGER, Matthias (org.). O método (auto)biográfico e a formação. Lisboa: Ministério da Saúde, 1988.

. "Alternance et recherche d'alternative: histoire de temps et de contretemps". Education Permanente, 1993, v. 2, n. 115, pp. 89-97.

—_. "Vers un paradigme de recherche-formation en réseau". Actas do Colóquio Estado Actual da Investigação e Formação. Porto: Sociedade Portuguesa de Ciências da Educação/ Afrontamento, 1994.

—. "Recherches sur l'autoformation existentielle: des boucles étranges entre auto et exoréférences". Education Permanente, 1995, v. 1, n. 122, pp. 165-78.

—. Accompagnements et histoire de vie. Paris : L'Harmattan, 1998.

—. "Histoire de vie et formation anthropologique de l'histoire humaine". Education Permanente, 2000a, v. 1, n. 142, pp. 63-70.

—. "La grande boucle étrange du mouvement des réseaux d'échanges réciproques de savoirs (MRERS) ". Education Permanente, 2000b, v. 3, n. 144, pp. 67-75.

—. "L'accompagnement en formation: de l'avant-naissance à l'après-mort - entre solidarité et professionnalité". Education Permanente, 2002, v. 4, n. 153, pp. 29-41.

— e LE GRAND, Jean-Louis. Les histoires de vie. Paris: Presses Universitaires de France, 1993. 
PINEAU, Gaston e MICHÈLE, Marie. Produire sa vie: autoformation et autobiographie. Paris: Editions Saint Martin, 1983.

PINTASSILGO, Joaquim. "O mestre como artesão/prático e como intelectual”. In MAGALHĀES, Justino e ESCOLANO, Agustín (orgs.). Os professores na história. Porto: Sociedade Portuguesa de Ciências da Educação, 1999, pp. 83-99.

PLUMMER, Ken. Los documentos personales: introducción a los problemas y la bibliografía del método humanista. Madri: Siglo XXI de España Editores, 1989.

POIRIER, Jean et al. Histórias de vida: teoria e prática. 2 ed. Oeiras: Celta, 1999.

POLETTINI, Altair, F. F. "Mudança e desenvolvimento do professor: o caso Sara". Revista Brasileira de Educação, 1998, n. 9, pp. 88-98.

POLLAK, Michel. "Memória, esquecimento, silêncio". Estudos Históricos, 1989, v. 2, n. 3, pp. 3-15.

—. "Memória e identidade social". Estudos Históricos, 1992, v. 5, n. 10, pp. 200-12.

PONTE, João Pedro e OLIVEIRA, Hélia. "Remar contra a maré: a construção do conhecimento e da identidade profissional na formação inicial". Revista de Educação, 2002, v. XI, n. 2, pp. 145-63.

PONTE, João Pedro et al. Por uma formação inicial de professores de qualidade. Documento de trabalho da Comissão ad hoc do CRUP para a formação de professores, 2000. Disponível em http://www.crup.pt/Documentos\%20PDF/forminicialqualidade.pdf. Acesso em ago. 2005.

PONTE, João Pedro et al. A formação de professores e o processo de Bolonha, 2004. Disponível em http://www.educ.fc.ul.pt/docentes/jponte/docs.pt/Parecer_formacao_professores(29Nov). pdf. Acesso em ago. 2005.

POPKEWITZ, Thomas S. "A profissionalização de professores: algumas notas sobre a sua história, ideologia e potencial (EUA)". In NÓVOA, António (org.). Os professores e sua formação. Lisboa: Publicaçôes Dom Quixote, 1992.

PORTELLA, Eduardo. Paradoxos da memória. Rio de Janeiro, 2002 (texto não publicado).

PORTELLI, Alessandro. "O massacre de Civitella Val di Chiana (Toscana: 29 de junho de 1944): mito, política, luto e senso comum”. In FERREIRA, Marieta de Moraes e AMADO, Janaina (orgs.). Usos e abusos da história oral. Rio de Janeiro: FGV, 2001.

PORTELLI, Patricia. "Un réseau d'échanges réciproques de savoirs: un lieu de pratiques sociales d'autoformation individuelle et collective?". Education Permanente, 1995, v. 1, n. 122, pp. 63-77.

QUARESMA, José Alberto. Créditos malparados? Algumas reflexões sobre o estado actual da formação contínua de professores, 2001. Disponível em http://www.criticanarede.com/ fil_creditosmalparados.html. Acesso em ago. 2005.

RAMALHO, Betânia Leite et al. "Quando o desafio é mobilizar o pensamento pedagógico do/a professor/a: uma experiência centrada na formação continuada”. Anais da XXII Reunião Anual da Associação Nacional de Pesquisa e Pós-Graduação em Educação. Caxambu, 2000.

RIBEIRO, Camilo. "Ser professor... ou professor ser?”. Revista Portuguesa de Educação, 1992, v. 5, n. 2, pp. 15-9.

RICOUER, Paul. Tempo e narrativa. Campinas, SP: Papirus, 1994, t. 1.

—. Teoria da interpretação: o discurso e o excesso de significação. Lisboa: Edições 70, 1996. 
RODRIGUES, Maria João. "Convergências e interdisciplinaridade da investigação em formação”. Actas do Colóquio da Sociedade Portuguesa de Ciências da Educação - Estado Actual da Investigação e Formação. Porto: Afrontamento, 1994.

ROLDÃO, Maria do Céu. "Formar profissionais: a centralidade do saber e do agir profissionais versus a discussão sobre modelos.” Revista de Educação, s. d., v. XI, n. 1, pp. 150-64.

ROSAS, Paulo. "Exame psicológico de candidatas ao magistério primário de Maceió". INEP, 1967, n. 107, pp. 111-45.

SACRISTÁN, José Gimeno. "Tendências investigativas na formação de professores”. In PIMENTA, S. G. e GHEDIN, Evandro (eds.). Professor reflexivo no Brasil: gênese e crítica de um conceito. São Paulo: Cortez, 2002, pp. 81-7.

SANCHES, Maria de Fátima Chorão. "A ilusão de poder: memórias de professores e mudança da escola". Actas do II Congresso da Sociedade Portuguesa de Ciências da Educação - Ciências da Educação: Investigação e Acção. Braga, 1995, v. II, pp. 7-24, 1995.

. "Ser professor: projecto, trajectos e modos de apropriação identitária". Revista de Educação, 2002, v. XI, n. 2, pp. 89-109.

SANTANA, Inácia. "A influência da escola moderna em percursos de formação". Inovação, 1993, v. 6, pp. 29-46.

SANTOS, Boaventura de Sousa. Um discurso sobre as ciências. Porto: Ediçōes Afrontamento, 1987.

—. Introdução a uma ciência pós-moderna. Porto: Edições Afrontamento, 1989.

- Pela mão de Alice: o social e o político na pós-modernidade. Porto: Edições Afrontamento, 1994.

- A crítica da razão indolente: contra o desperdício da experiência. Porto: Edições Afrontamento, 2000.

SARMENTO, Manuel Jacinto. A vez e a voz dos professores. Porto: Porto, 1994.

—_. "O estudo de caso etnográfico em educação". In VILELA, Rita Amélia T. et al. Itinerários de pesquisa: perspectivas qualitativas em sociologia da educação. Rio de Janeiro: DP\&A, 2003.

SARMENTO, Teresa. Histórias de vida de educadoras de infância. Lisboa: Instituto de Inovação Educacional/Ministério da Educação, 2002.

SCHÖN, A. "A la recherche d'une nouvelle épistémologie de la pratique et de ce qu'elle implique pour l'éducation des adultes". In BARBIER, Jean-Marie (Org.). Savoirs theóriques et savoirs d'action. Paris: Presses Universitaires de France, 1966, pp. 201-22.

SCHÖN, Donald. "Formar professores como profissionais reflexivos". In NÓVOA, Antonio (org.). Os professores e sua formação. Lisboa: Publicações Dom Quixote, 1992.

SÈVE, Lucien. "Marxisme et théorie de la personnalité: retour sur la genèse d'un livre". Education Permanente, 2000, v. 1, n. 142, pp. 11-25.

SHEIBE, Leda. "Formação e identidade do Pedagogo no Brasil". In CANDAU, Vera (org.). Ensinar e aprender: sujeitos, saberes e pesquisa. Rio de Janeiro: DP\&A, 2001.

SILVA, Maira Isabel Lopes. "A investigação-acção, uma estratégia de formação... e de investigação?”. Actas do Colóquio da Sociedade Portuguesa de Ciências da Educação. Estado Actual da Investigação e Formação. Porto: Afrontamento, 1994.

SILVA, Tomaz. T. "A produção social da identidade e da diferença”. Identidade e diferença: a perspectiva dos estudos culturais. Petrópolis, RJ: Vozes, 2000. 
SIM-SIM, Inês. "Os professores que hoje temos e os professores que vamos ter amanhā". Inovação, 1994, n. 7, pp. 145-71.

SMOLKA, Ana Luiza Bustamente. "A memória em questão: uma perspectiva histórico-cultural”. Educação e Sociedade, 2000, n. 71, pp. 166-93.

SOCORRO, Maria et al. "Perfil de professoras do $1^{\circ}$ ciclo: questões socioculturais e pedagógicas”. Revista Brasileira de Estudos Pedagógicos, 2006, n. 215, pp. 29-43.

SOUSA, Cynthia Pereira. "Fragmentos de histórias de vida e de formação de professoras paulistas: rupturas e acomodaçōes". In --- (org.). História da educação: processos, práticas e saberes. São Paulo: Escrituras, 1998.

— et al. "Memória e autobiografia: formação de mulheres e formação de professoras". Revista Brasileira de Educação, 1996, n. 2, pp. 61-76.

SOUSA, Jesus Maria. O professor como pessoa. Porto: Asa Editores, 2000.

SOUZA, Elizeu Clementino de. O conhecimento de si: estágio e narrativas de formação de professores (tese). UFBA, 2004.

—. "A formação como processo de conhecimento: histórias de vida e abordagem (auto) biográfica”. In BRAGANÇA, I. F. S. et al. (orgs.). Vozes da educação: memórias, histórias e formação de professores. Petrópolis: DP et Alii, 2008.

— e MIGNOT, Ana Chrystina Venancio. Histórias de vida e formação de professores. Rio de Janeiro: Quartet/Faperj, 2008.

SOUZA, Maria Cecília Cortez Christiano. A escola e a memória. Bragança Paulista: IFAN-CDAPH/Ed. da Universidade de São Francisco, 1987.

—_. "Professores e professoras: retratos feitos de memória (Brasil, final do século XIX e início do século XX)". In GONDRA, José (org.). Dos arquivos à escrita da história: a educação brasileira entre o Império e a República. 2 ed. Bragança Paulista: EDUSF, 2002.

STANO, Rita de Cássia M. T. Identidade do professor no envelhecimento. São Paulo: Cortez, 2001.

STOER, Stephen. "Metodologias actuais de investigação no campo da formação". Actas do Colóquio Estado Actual da Investigação e Formação. Porto: Sociedade Portuguesa de Ciências da Educação/Afrontamento, 1994, pp. 53-8.

- et al. "Formação de professores e o $1^{\circ}$ ciclo do ensino básico: deveríamos ou não ter saudades das escolas do magistério primário?”. Educação, Sociedade e Culturas, 1999, v. 11 , pp. 165-204.

TANURI, Leonor Maria. "História da formação de professores". Revista Brasileira de Educação, 2000, n. 14, pp. 61-88.

TARDIF, Maurice. "Saberes profissionais dos professores e conhecimentos universitários". Revista Brasileira de Educação, 2000, n. 13, pp. 5-24.

— e GAUTHIER, Clermont. "L'enseignant comme 'acteur rationnel': quelle rationalité, quel savoir, quel jugement?”. In PAQUAY, Léopold et al. (orgs.). Former des enseignants professionnels: quelles stratégies? Quelles copétences? 3 ed. Bruxelas: De Boeck Université, 2001, pp. 209-38.

TAVARES, José. "Formação inicial e contínua dos professores, realidades e perspectivas". Revista Portuguesa de Educação, 1988, v. 1, n. 3, pp. 109-24. 
- "Investigação e acção nos processos de formação de professores e educadores". Actas do II Congresso da Sociedade Portuguesa de Ciências da Educação - Ciências da Educação: Investigação e Acção. Braga, 1995, v. I, pp. 39-50.

TAVARES, Maria Tereza Goudard. "Percursos e movimentos: dez anos do Vozes da Educação em São Gonçalo”. In BRAGANÇA, I. F. S. et al. (orgs.). Vozes da Educação: memórias, histórias e formação de professores. Petrópolis: DP et Alii, 2008.

TEIXEIRA, José Manuel. "Uma discussão urgente: revisão do estatuto da carreira docente". A Página, 2006, v. 159, n. 14, s. p.

TEODORO, António. "Crise de identidade nos papéis e na formação de professores: quatro tópicos a partir de uma leitura sociológica”. In MAGALHÂES, Justino e ESCOLANO, Agustín (orgs.). Os professores na história. Porto: Sociedade Portuguesa de Ciências da Educação, 1999, pp. 59-68.

—_. "Educação e políticas educativas no Portugal contemporâneo: da construção do modelo escolar ao tesouro a descobrir”. Revista Lusófona de Educação, 2003, n. 1, pp. 127-44.

TERSSAC, G. "Savoirs, compétences et travail”. In BARBIER, Jean-Marie (org.). Savoirs theóriques et savoirs d'action. Paris: Presses Universitaires de France, 1996, pp. 223-48.

THOMPSON, Paul. A voz do passado. São Paulo: Paz e Terra, 1998.

THOMSON, Alistair et al. "Os debates sobre memória e história: alguns aspectos internacionais”. In FERREIRA, Marieta de Moraes e AMADO, Janaina (orgs.). Usos e abusos da história oral. Rio de Janeiro: FGV, 2001.

TOCHON, F. "Grammaires de l'expérience et savoirs-objets: le savoir focal dans la construction de nouveaux modèles de formation”. BARBIER, Jean-Marie (org.). Savoirs theóriques et savoirs d'action. Paris: Presses Universitaires de France, 1996, pp. 249-74.

TORRES, Rosa M. “Tendências da formação docente nos anos 1990". In WARDE, M. J. Novas políticas educacionais: criticas e perspectivas. São Paulo: Programa de Estudos Pós-Graduados em Educação, História e Filosofia da Educação da PUC, 1998.

TREMBLAY, Nicole A. e BALLEUX, André. “La galaxie 'auto' dans l'univers de l'andragogie: une première analogie". Education Permanente, 1995, v. 1, n. 122, pp. 149-63.

TRINDADE, Vítor e OLIVEIRA, Vítor. "Formação inicial de professores e as disciplinas de didáctica das ciências na Universidade de Évora”. Revista de Educação, 1993, v. III, n. 2, pp. 77-82.

VALENTE, Maria Odete. "Formação de professores na Faculdade de Ciências da Universidade de Lisboa: potencialidades, fragilidades, desafios”. Revista de Educação, 2002, v. XI, n. 1, pp. 162-4.

VASCONCELOS, Geni Amélia Nader (org.). Como me fiz professora. Rio de Janeiro: DP\&A, 2000.

VASCONCELOS, Teresa Maria Sena. "Investigação qualitativa e qualidade na educação: da etnografia num jardim de infância ao poder da metáfora”. Actas do II Congresso da Sociedade Portuguesa de Ciências da Educação - Ciências da Educação: Investigação e Acção. Braga, 1995, v. II, pp. 349-59.

_ _ "Da mesa grande à pedagogia dos gestos quotidianos: estudo etnográfico num jardim de infância”. Inovação, 1997, n. 10, pp. 55-72.

VAZ, Armando. "Episódios e narrativas de professores: experiências e perspectivas docentes discutidas a partir de pesquisa sobre o conhecimento pedagógico de conteúdo". Anais da 
XXIV Reunião Anual da Associação Nacional de Pesquisa e Pós-Graduação em Educação. Caxambu, 2001.

VELAZQUEZ, Gabriela Elizabeth et al. "El componente de la investigación en los institutos de formación docente: formar docentes investigadores ó investigar con los docentes?”. Anais da XXIII Reunião Anual da Associação Nacional de Pesquisa e Pós-Graduação em Educação. Caxambu, 2000.

VEYNE, Paul. Acreditavam os gregos em seus mitos? Ensaio sobre a imaginação constituinte. São Paulo: Brasiliense, 1984.

VIDAL, Diana Gonçalves. "A fonte oral e a pesquisa em história da educação". Educação em Revista, 1998, n. 98, pp. 7-16.

— e CARVALHO, Marília Pinto. "Mulheres e magistério primário: tensôes, ambiguidades e deslocamentos". In VIDAL, Diana Gonçalves e HILSDORF, Maria Lúcia Spedo (orgs.). Brasil 500 anos: tópicos em história da educação. São Paulo: EDUSP, 2001.

VIDAL, Octavi Roca Núria. "L'autoformation en Espagne: des centres d'auto-apprentissage aux systèmes de formation personnalisée". Education Permanente, 1995, v. 1, n. 122, pp. 125-30.

VIDIGAL, Luís. "História oral, experiências de aprendizagem e enraizamento sociocultural - um projeto em curso". Educação e Sociedade, 1995, n. 52, pp. 474-503.

VIEIRA, Ricardo. Histórias de vida e identidades: professores e interculturalidade. Porto: Afrontamento, 1999.

—. Ser igual, ser diferente: encruzilhadas da identidade. Porto: Profediçōes, 2000.

—_. "Identidades, histórias de vida e culturas escolares: contribuiçōes e desafios para a formação de professores". In BRAGANÇA, I. F. S. et al. (orgs.). Vozes da educação: memórias, histórias e formação de professores. Petrópolis: DP et Alii, 2008.

VILELA, Heloisa. "A primeira escola normal do Brasil". In Nunes, Clarice (org.). O passado sempre presente. São Paulo: Cortez, 1992.

WEBER, Silke. "Como e onde formar professores: espaços em confronto". Educação \& Sociedade, 2000, n. 70, pp. 129-55.

WERTHEIN, Jorge. Caminhos do pensamento: horizontes da memória. Rio de Janeiro: 2000 (texto não publicado).

WOODS, Peter e TROMAN, Geoff. "Sociedade, estresse e identidade do professor". Revista de Educação, 2002, v. XI, n. 2, pp. 75-87.

WOODWARD, Kathryn. "Identidade e diferença: uma introdução teórica e conceitual". In SILVA, T. T. Identidade e diferença: a perspectiva dos estudos culturais. Petrópolis, RJ: Vozes, 2000.

ZABALZA, Miguel Ángel. Diários de aula. Porto: Porto, 1994.

ZACCUR, Edwiges. "Cadernos de registros: uma prática pesquisadora". In MIGNOT, Ana Chrystina Venancio e CUNHA, Maria Teresa Santos (orgs.). Práticas de memória docente. São Paulo: Cortez, 2003.

ZEICHNER, Kenneth M. El maestro como profesional reflexivo. Cuadernos de Pedagogia, 1992, n. 220, pp. 44-9.

__. "Tendências da pesquisa sobre formação de professores nos Estados Unidos". Revista Brasileira de Educação, 1998, n. 9, pp. 76-87. 
Anexos 


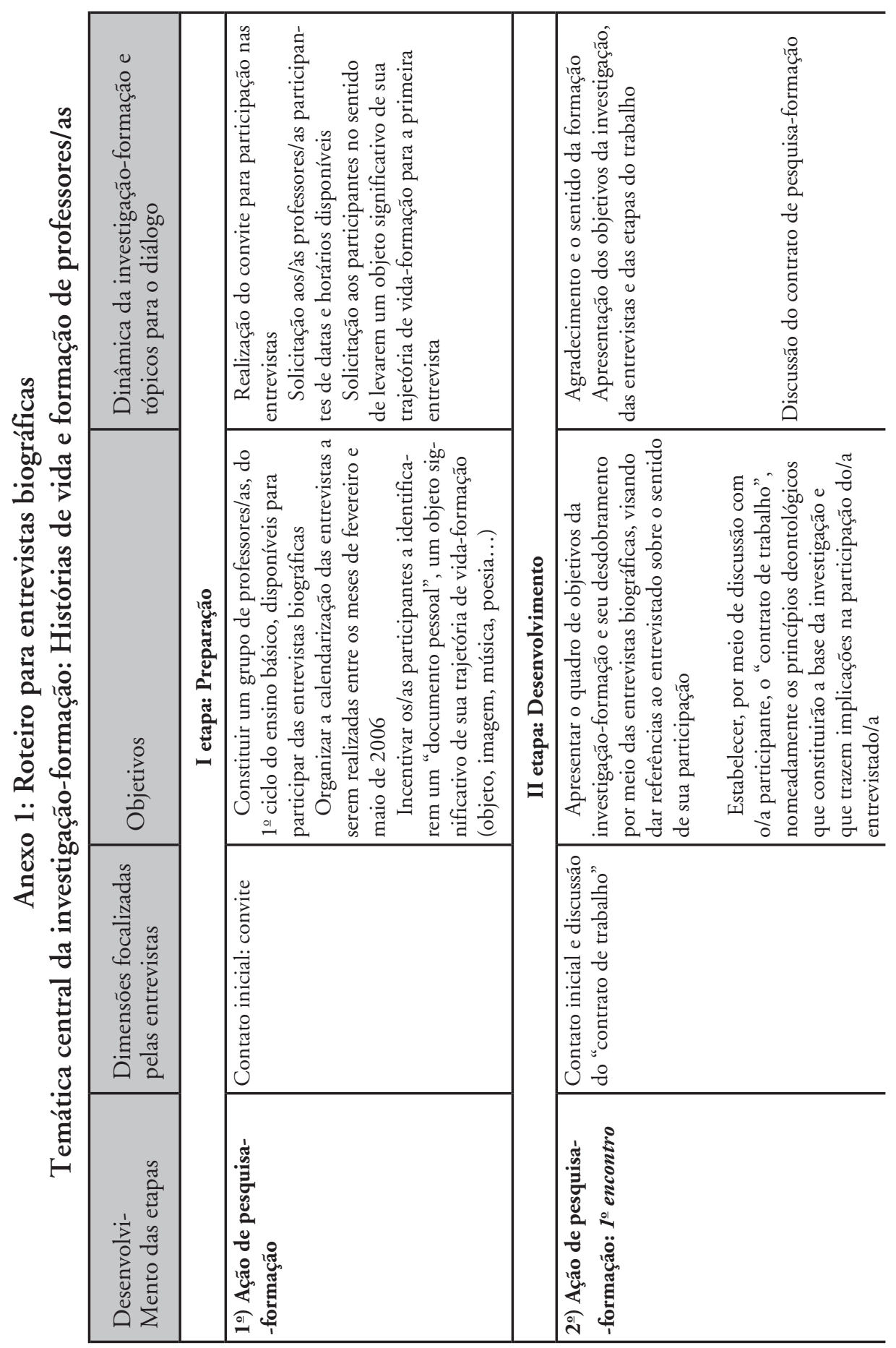




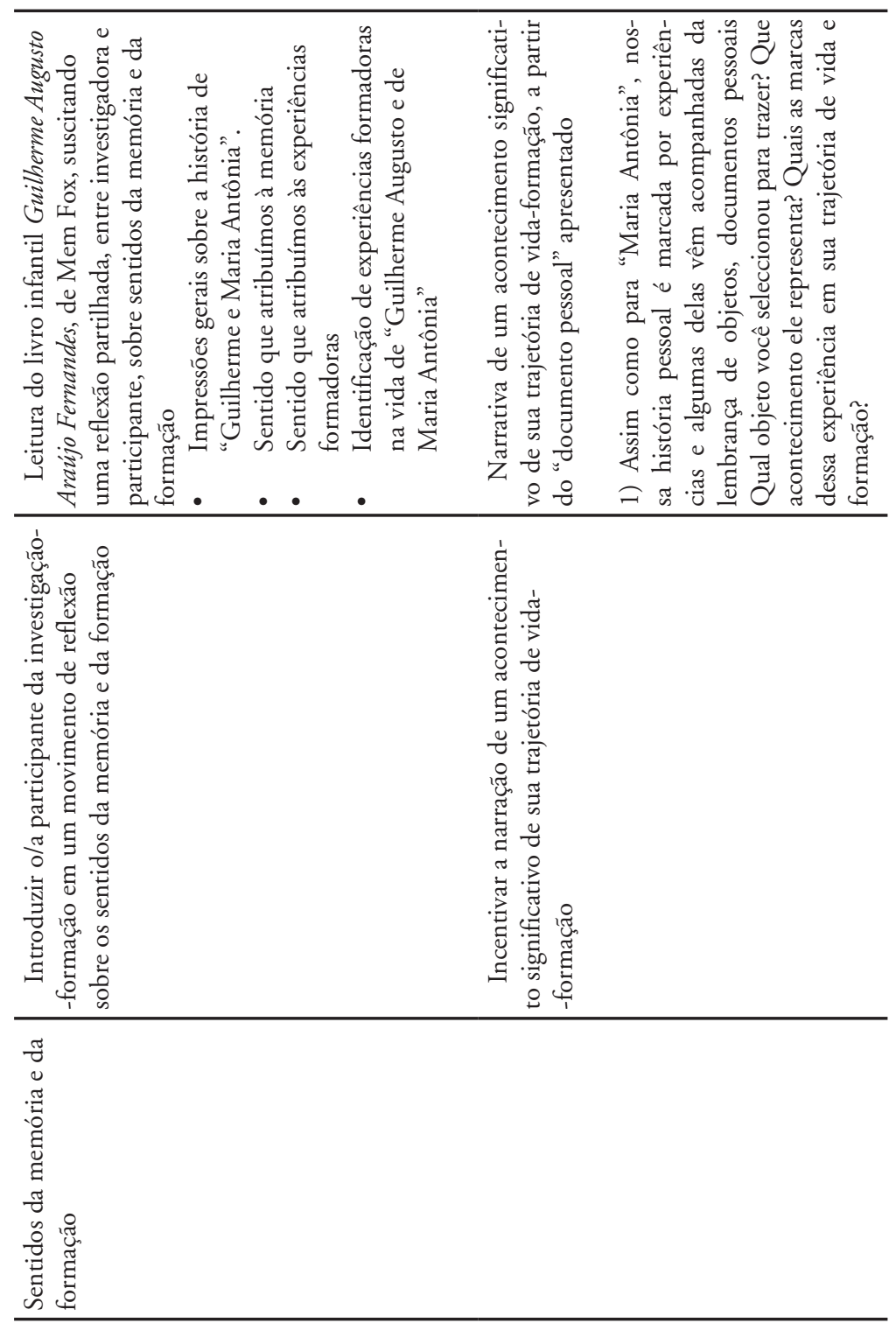




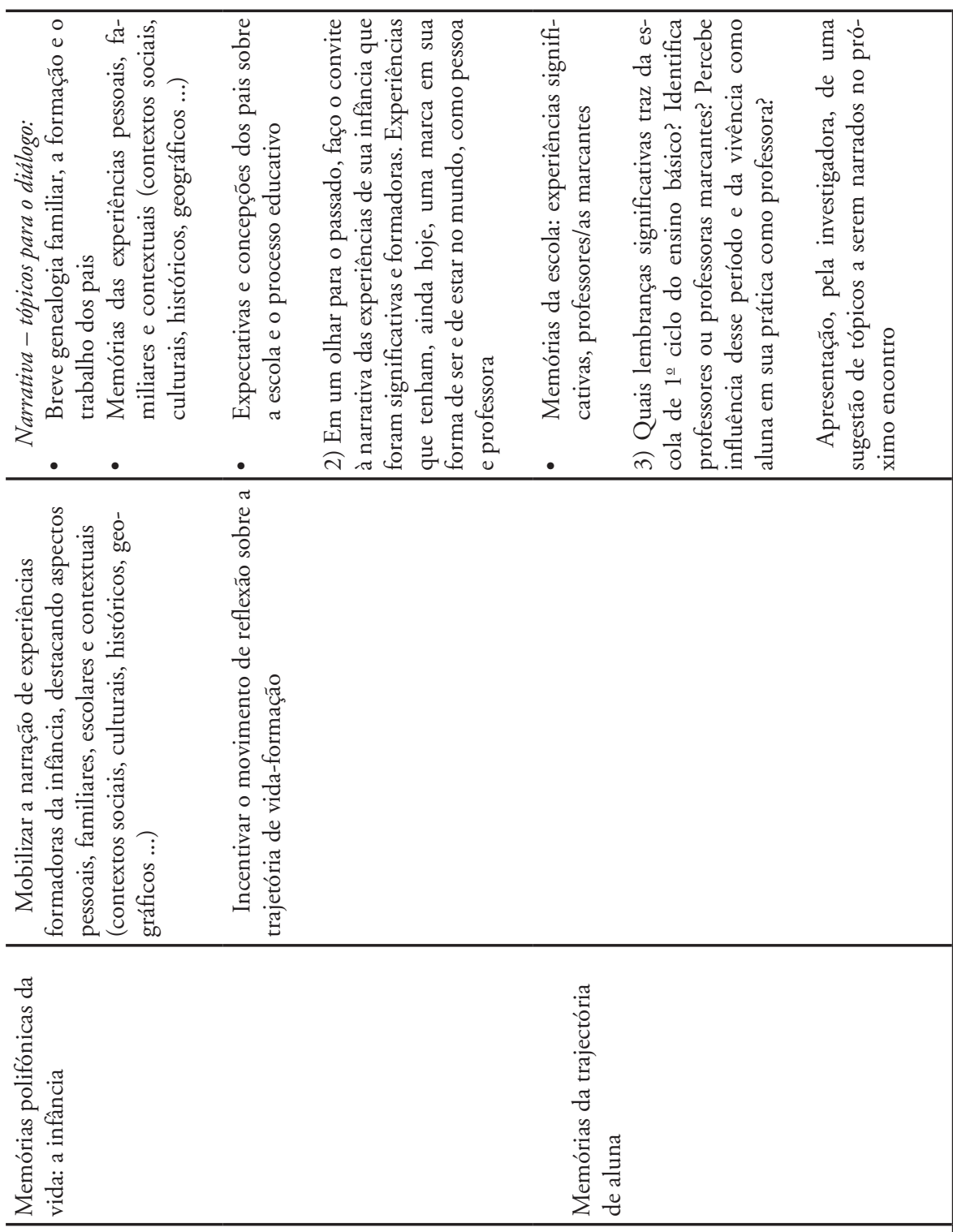




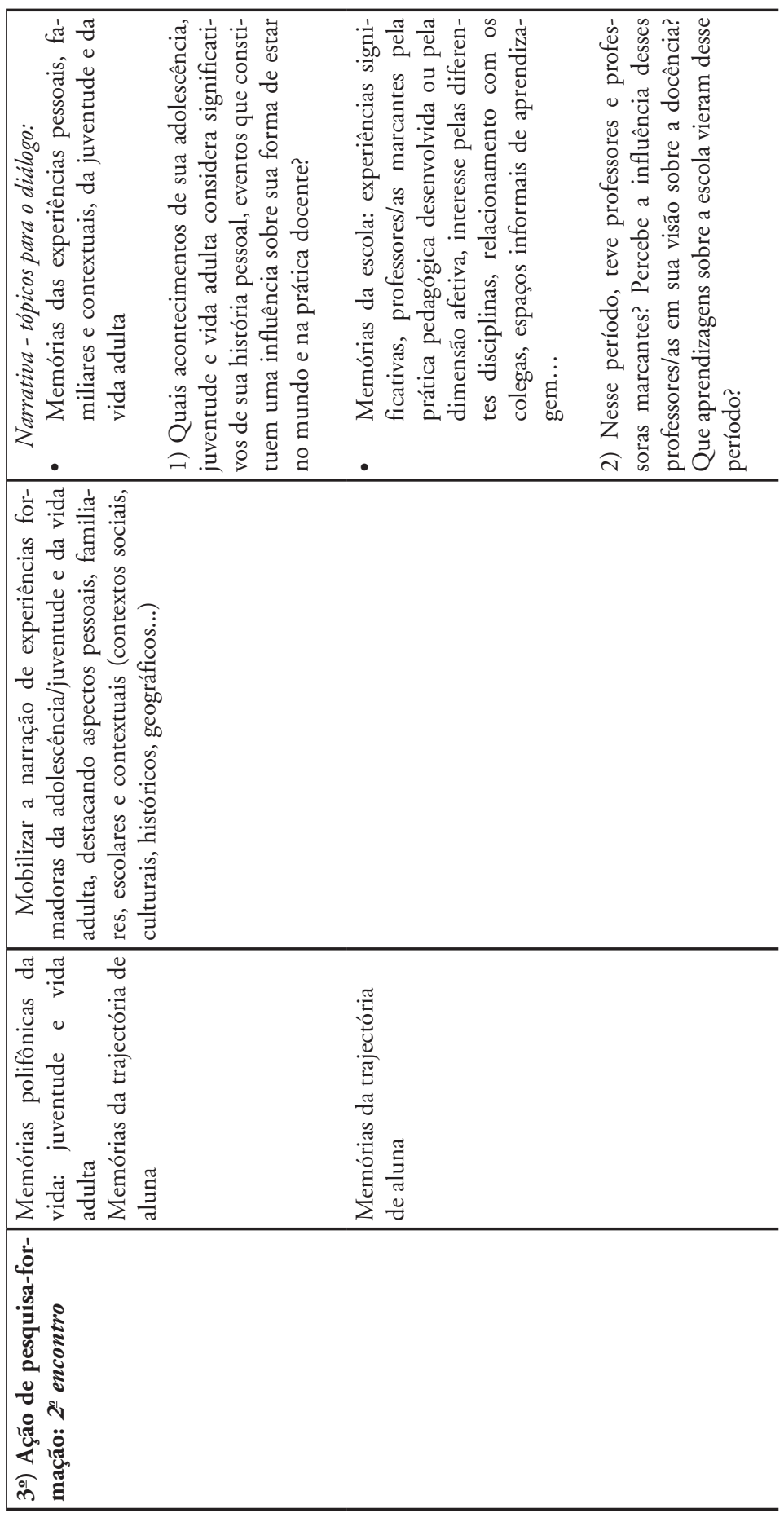




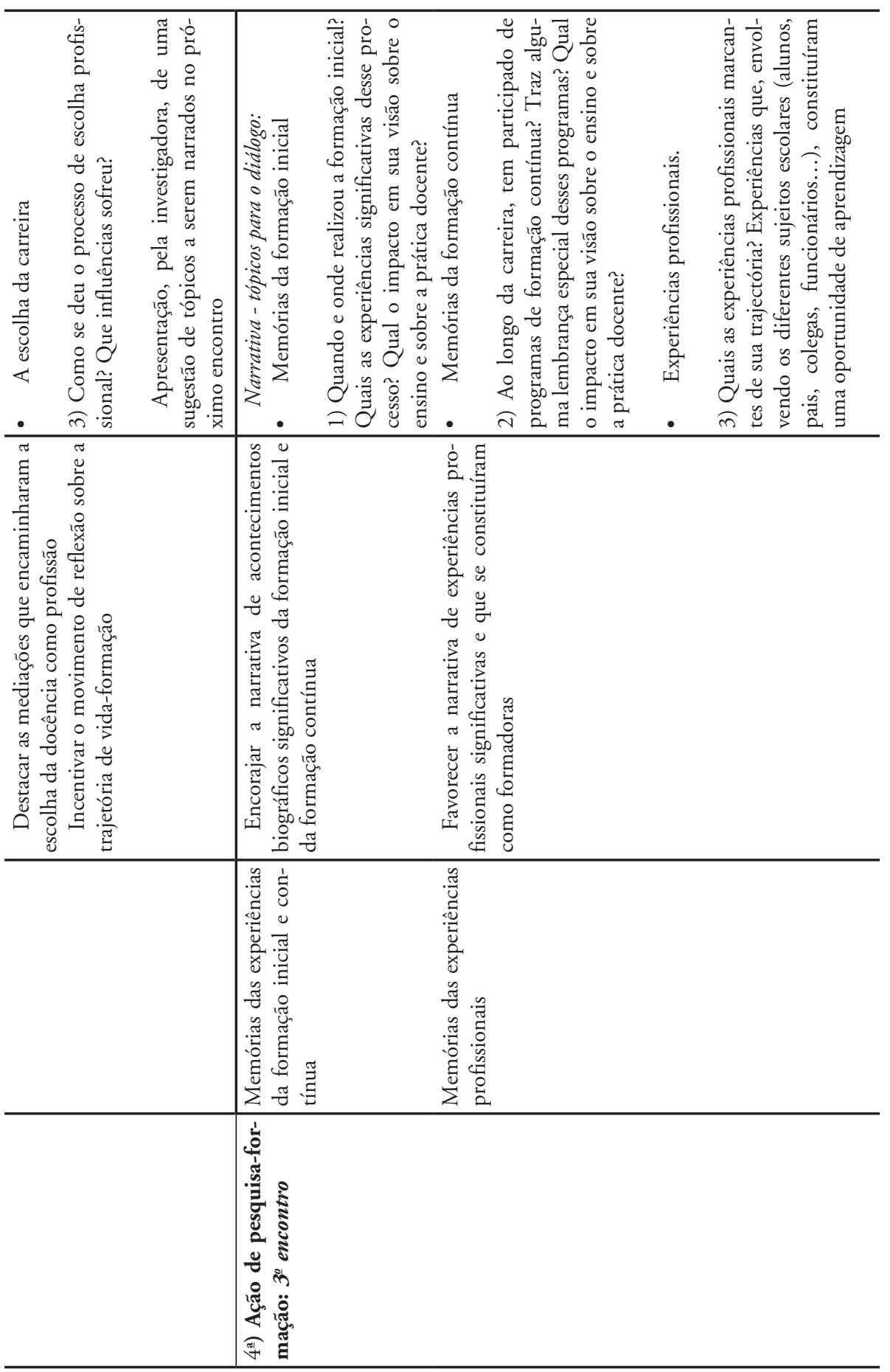




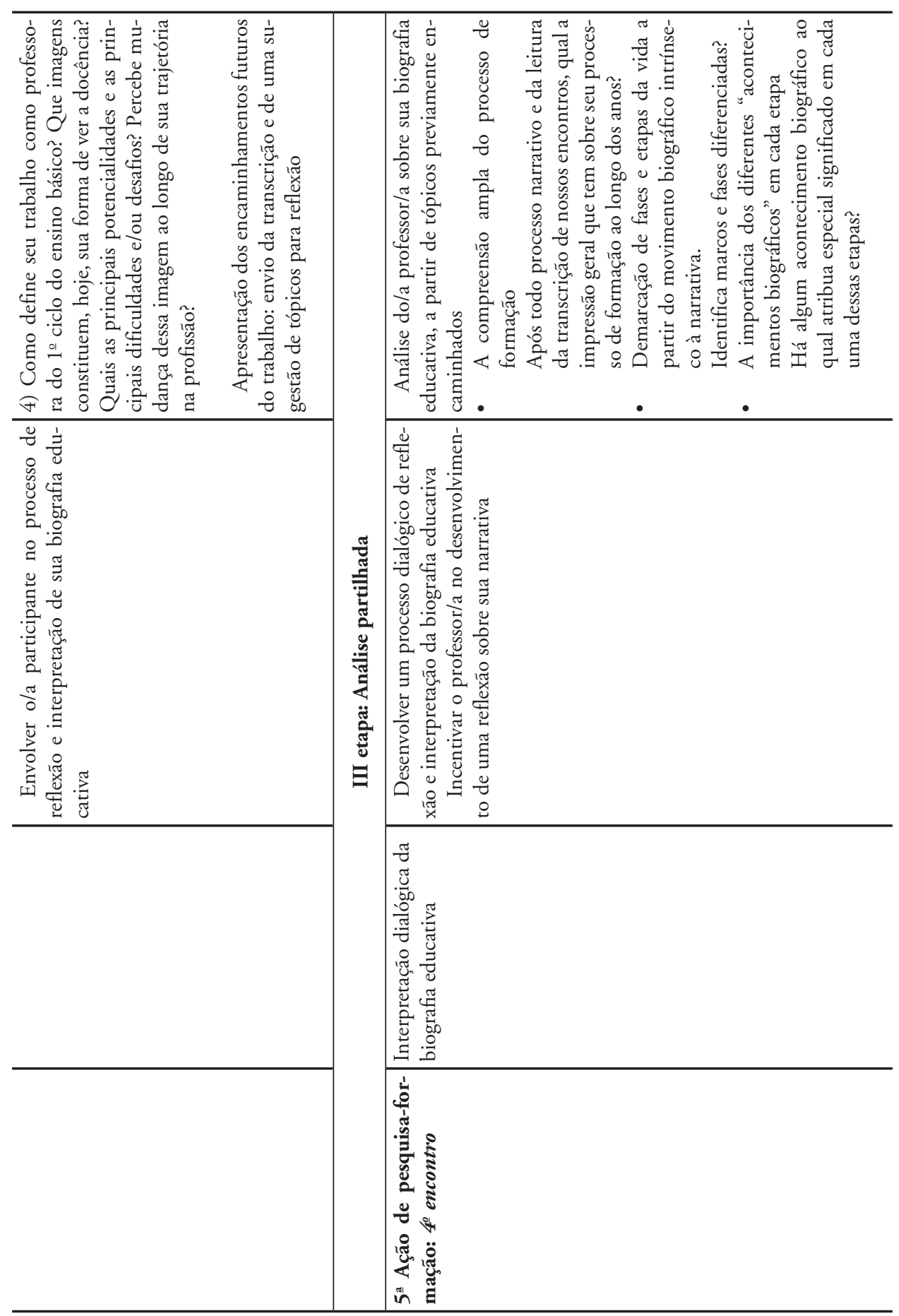




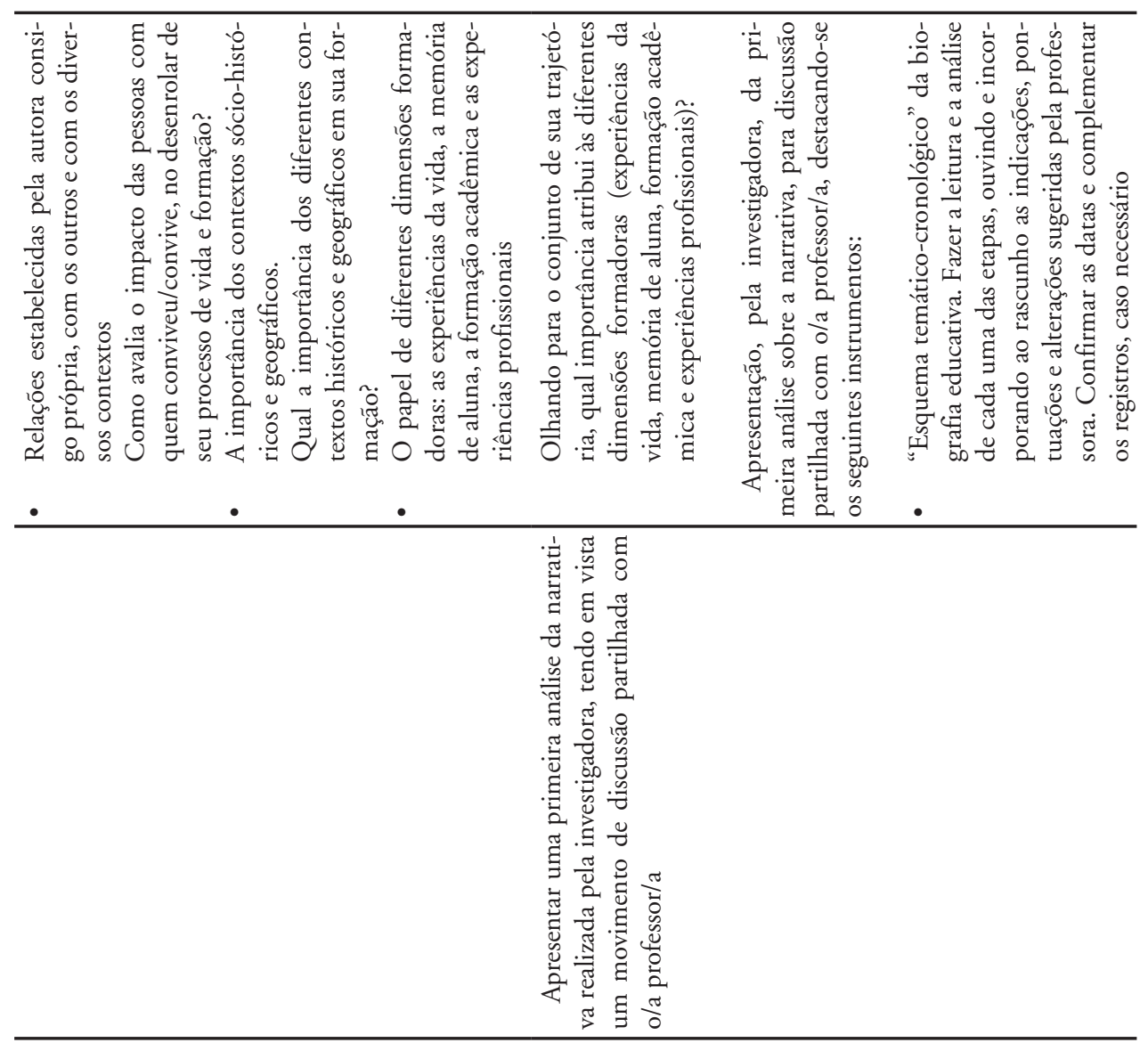




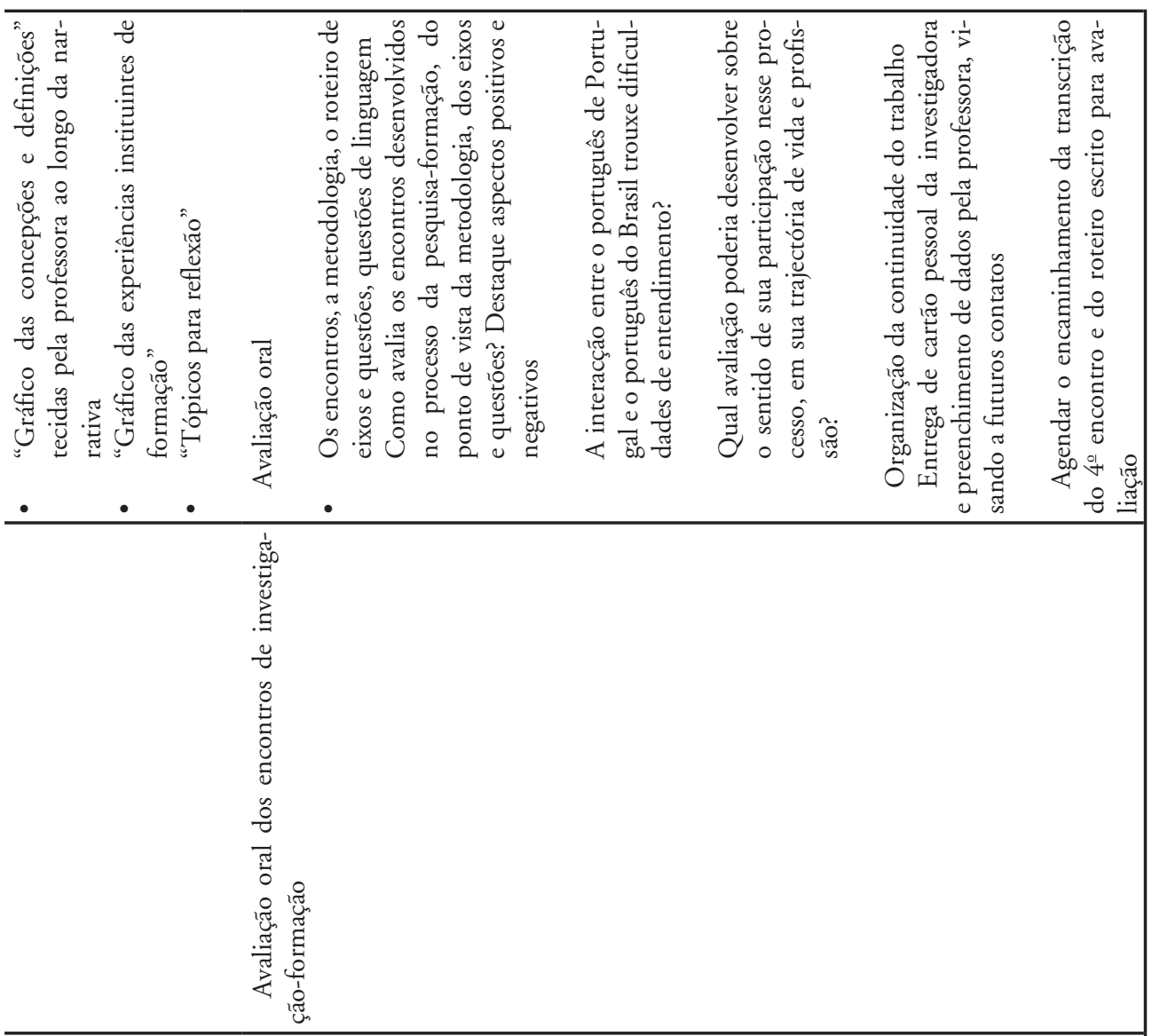


302 Histórias de vida e formação de professores: diálogos entre Brasil e Portugal

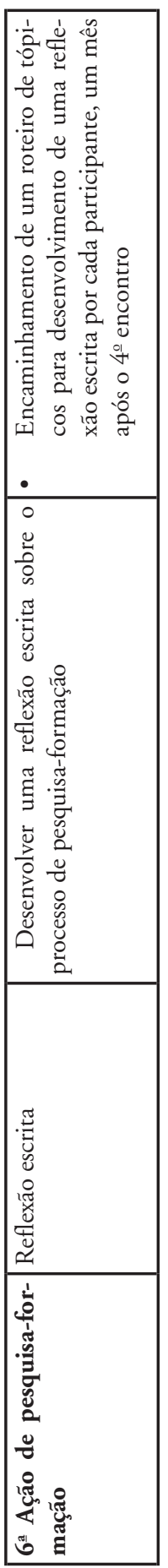




\section{Referências}

Observação: A organização da metodologia de trabalho e o presente roteiro tomam como referência um conjunto de estudos realizados por meio de revisão da literatura portuguesa e brasileira, dentre os quais destaco:

ARAÚJO, Helena Costa e MAGALHĀES, Maria José. Des-fiar as vidas. Perspectivas biográficas, mulheres e cidadania. Lisboa: Comissão para Igualdade e para os Direitos das Mulheres, 2000.

BUENO, B. O. et al. A vida e o oficio dos professores: formação contínua, autobiografia e pesquisa em colaboração. São Paulo: Escrituras, 1998.

- Autobiografias e formação de professores: um estudo sobre representações de alunas de um curso de magistério (tese de livre-docência). USP, 1996.

CAVACO, Maria Helena. "O ofício do professor: o tempo e as mudanças". In NÓVOA, António (org.). Profissão professor. 2 ed. Porto: Porto, 1995, pp. 7-34.

COUCEIRO, Maria do Loureto Paiva. Processo de autoformação: uma produção singular de si próprio. Monte de Caparica: Universidade Nova de Lisboa, 1992.

DOMINICÉ, Pierre. Learning from our lives: using educational biographies with adults. São Francisco: Jossey-Bass, 2000.

JOSSO, Marie-Christine. Cheminer vers soi. Suisse: Editions l'Age d'Homme, 1991.

- Cheminer avec: interrogations et défis posés par la recherche d'un art de la convivance en histoire de vie. In: PINEAU, Gaston (ed.). Accompagnements et histoire de vie. Paris: L'Harmattan, 1998.

—. Experiências de vida e formação. Lisboa: Educa, 2002.

KRAMER, Sonia. "Leitura e escrita de professores". Revista Brasileira de Educação, 1998, n. 7, pp. 19-41.

LINHARES, Célia. Experiências instituintes em escolas públicas e formação docente: Brasil e Portugal. Niterói, Projecto de Investigação, 2005 (mimeo.).

- Relatório resumido. Niterói, 2005 (mimeo.).

MALPIQUE, Manuela. Histórias de vida. Porto: Campo das Letras, 2002.

MOITA, Maria da Conceição. "Percursos de formação e de trans-formação". In NÓVOA, António (org.). Vidas de professores. Porto: Porto, 1992.

PINEAU, Gaston (ed). Accompagnements et histoire de vie. Paris : L'Harmattan, 1998. e MICHELE, Marie. Produire sa vie: autoformation et autobiographie. Paris: Editions Saint Martin, 1983.

SARMENTO, Teresa. Histórias de vida de educadoras de infância. Lisboa: Instituto de Inovação Educacional/Ministério da Educação, 2002, pp. 1-44, 77-81, 98-129, 252-412.

SOUSA, Cynthia P. et al. "Memória e autobiografia: formação de mulheres e formação de professoras". Revista Brasileira de Educação, 1996, n. 2, pp. 61-76.

VIEIRA, Ricardo. Histórias de vida e identidades: professores e interculturalidade. Porto: Afrontamento, 1999. 


\section{Anexo 2: Contrato de trabalho pedagógico-acadêmico}

A realização das "entrevistas biográficas", no contexto da pesquisa Histórias de vida e formação de professores/as, toma como pressupostos deontológicos os seguintes princípios:

- implicação voluntária;

- confidencialidade dos nomes dos/as entrevistados/as e dos respectivos locais de trabalho;

- disponibilidade de enunciação de sua história de vida pelos/as participantes, nomeadamente focada na biografia educativa;

- gravação e transcrição de todas as entrevistas, pela investigadora;

- leitura e revisão, pelo/a entrevistado/a, da transcrição de todas as entrevistas realizadas, destacando-se o carácter de revisão pontual que não altere o conteúdo, nem a característica de oralidade;

- realização da análise de conteúdo das entrevistas, pela investigadora;

- participação do/a entrevistado/a na interpretação/análise de sua própria narrativa, valorizando-se a pluralidade de perspectivas de análise;

- a partir do material das entrevistas biográficas, elaboração da biografia educativa do/a participante, pela investigadora, utilizando fragmentos das narrativas;

- leitura e considerações, pelo/a entrevistado/a, da biografia educativa redigida pela investigadora (facultativo aos participantes);

- o conteúdo do trabalho constituirá material empírico para o desenvolvimento de uma pesquisa de doutoramento em Educação, assim, será efetuada uma análise, tendo em vista os objetivos da investigação;

- envio da análise final da biografia educativa para leitura e consideração pelos/as narradores/as (facultativo aos participantes);

- os/as entrevistados/as autorizam a inclusão das transcrições das entrevistas no corpo da tese ou em anexo;

- os/as entrevistados/as autorizam a inclusão da biografia educativa, a ser elaborada pela investigadora, no corpo da tese ou em anexo; 
- os/as entrevistados autorizam/as a inclusão da análise realizada pela investigadora, bem como de citações e fragmentos das biografias educativas na tese, como em carácter editorial, incluindo artigos, livros e trabalhos acadêmicos em geral;

- caso as biografias educativas, em sua versão integral, sejam objeto de publicação editorial, tal procedimento deverá contar com outra autorização do autor, já que o referido material é de propriedade do/a narrador/a;

- os entrevistados deverão receber uma cópia digitalizada do trabalho final, ou seja, da tese de doutoramento;

- a realização das entrevistas apresenta natureza essencialmente pedagógica, de formação e pesquisa.

\section{Anexo 3: Roteiro de tópicos para reflexão}

\section{Sugestão de roteiro para a $1^{\mathrm{a}}$ entrevista:}

apresentação dos objetivos da investigação, das entrevistas e das etapas do trabalho;

discussão do contrato de pesquisa-formação;

leitura do livro infantil Guilherme Augusto Araújo Fernandes, de Mem Fox, suscitando uma reflexão partilhada, entre investigadora e participante, sobre os sentidos da memória e da formação;

narrativa de um acontecimento significativo de sua trajetória de vida-formação, a partir do "documento pessoal" apresentado.

\section{Narrativa - tópicos para o diálogo:}

- experiências formadoras da infância: memórias das experiências pessoais, familiares e contextuais (espaços geográficos, contextos históricos...);

- breve genealogia familiar, a formação e o trabalho dos pais;

- expectativas e representaçóes dos pais sobre a escola e o processo educativo;

- memórias da escola: experiências significativas, professores/as marcantes. 
Apresentação, pela investigadora, de uma sugestão de tópicos a serem narrados no próximo encontro.

Sugestão de roteiro para a $2^{\mathrm{a}}$ entrevista:

Narrativa - tópicos para o diálogo:

- eventos que constituíram uma influência sobre a forma de ser e de estar no mundo e na prática docente: memórias das experiências pessoais, familiares e contextuais, da juventude e da vida adulta;

- memórias da escola: experiências significativas, professores/as marcantes;

- a escolha da carreira.

Sugestão de roteiro para a $3^{\mathrm{a}}$ entrevista:

Narrativa - tópicos para o diálogo:

- memórias da formação inicial;

- memórias da formação contínua;

- experiências profissionais.

\section{Anexo 4: Sugestão de tópicos para interpretação da biografia educativa}

- A compreensão ampla do processo de formação.

- Demarcação de fases e etapas da vida, a partir do movimento biográfico intrínseco à narrativa.

- A importância dos diferentes "acontecimentos biográficos" em cada etapa.

- Relações estabelecidas pela autora consigo própria, com os outros e com os diversos contextos.

- A importância dos contextos sócio-históricos e geográficos.

- O papel de diferentes dimensóes formadoras: as experiências da vida, a memória de aluna, a formação académica e as experiências profissionais. 


\section{Anexo 5: Sugestão de tópicos para reflexão escrita}

Queluz, 12 de junho de 2006.

Professora,

Agradeço, de forma especial, sua participação no processo de investigação proposto, os momentos de aprendizagem e partilha. Solicito que desenvolva uma reflexão escrita sobre o trabalho e sugiro abaixo alguns itens que constituem apenas uma indicação. Fique à vontade para desenvolver uma abordagem crítica e pessoal.

Com grande estima e agradecimento,

Inês.

\section{Sugestão de itens para reflexão escrita:}

- avaliação dos encontros desenvolvidos no processo de pesquisaformação, destacando aspectos positivos e negativos;

- sentido/contributo do movimento de narrativa e rememoração, em sua trajetória de vida e formação;

- análise do significado da partilha da vida, em seus movimentos formadores, entrelaçando memórias pessoais, formação acadêmica e experiências profissionais. 


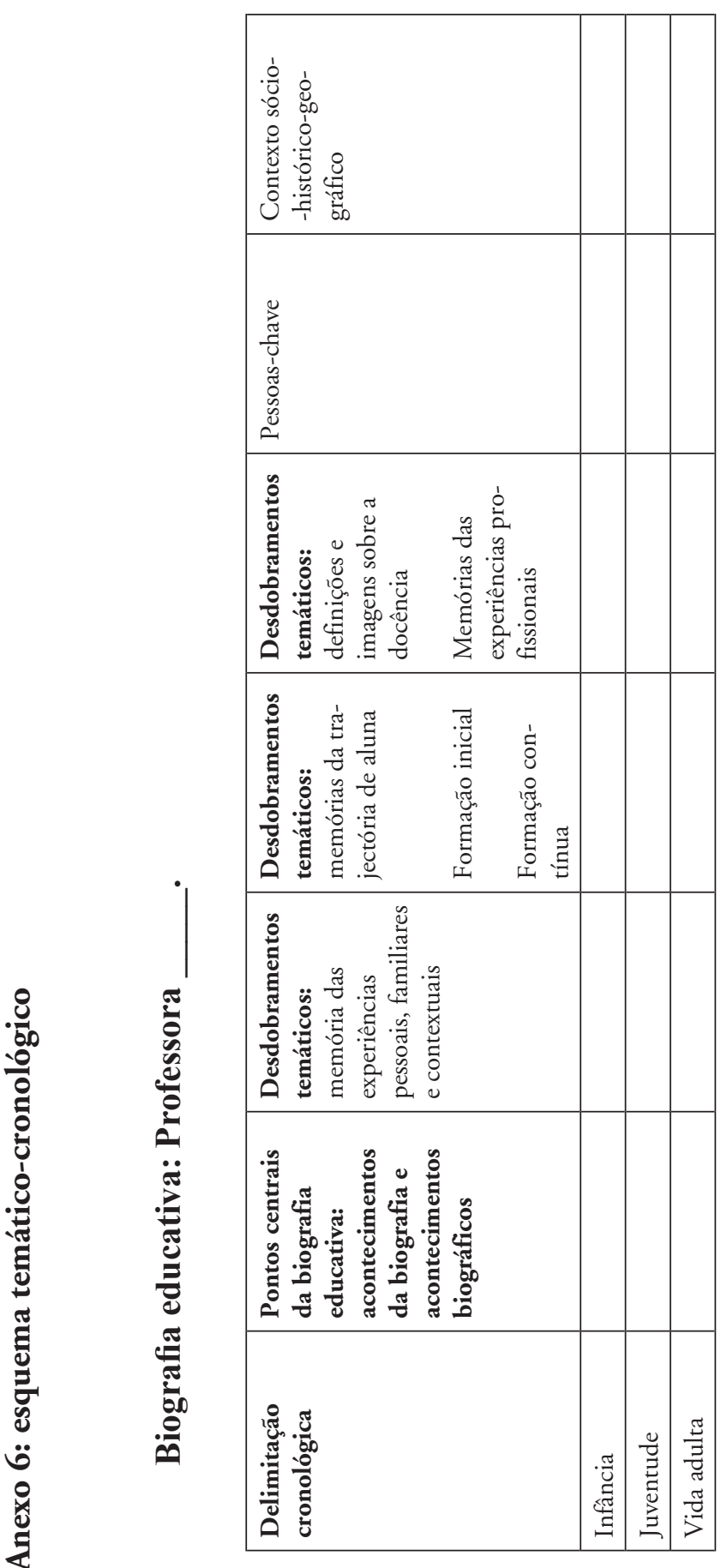


Anexo 309
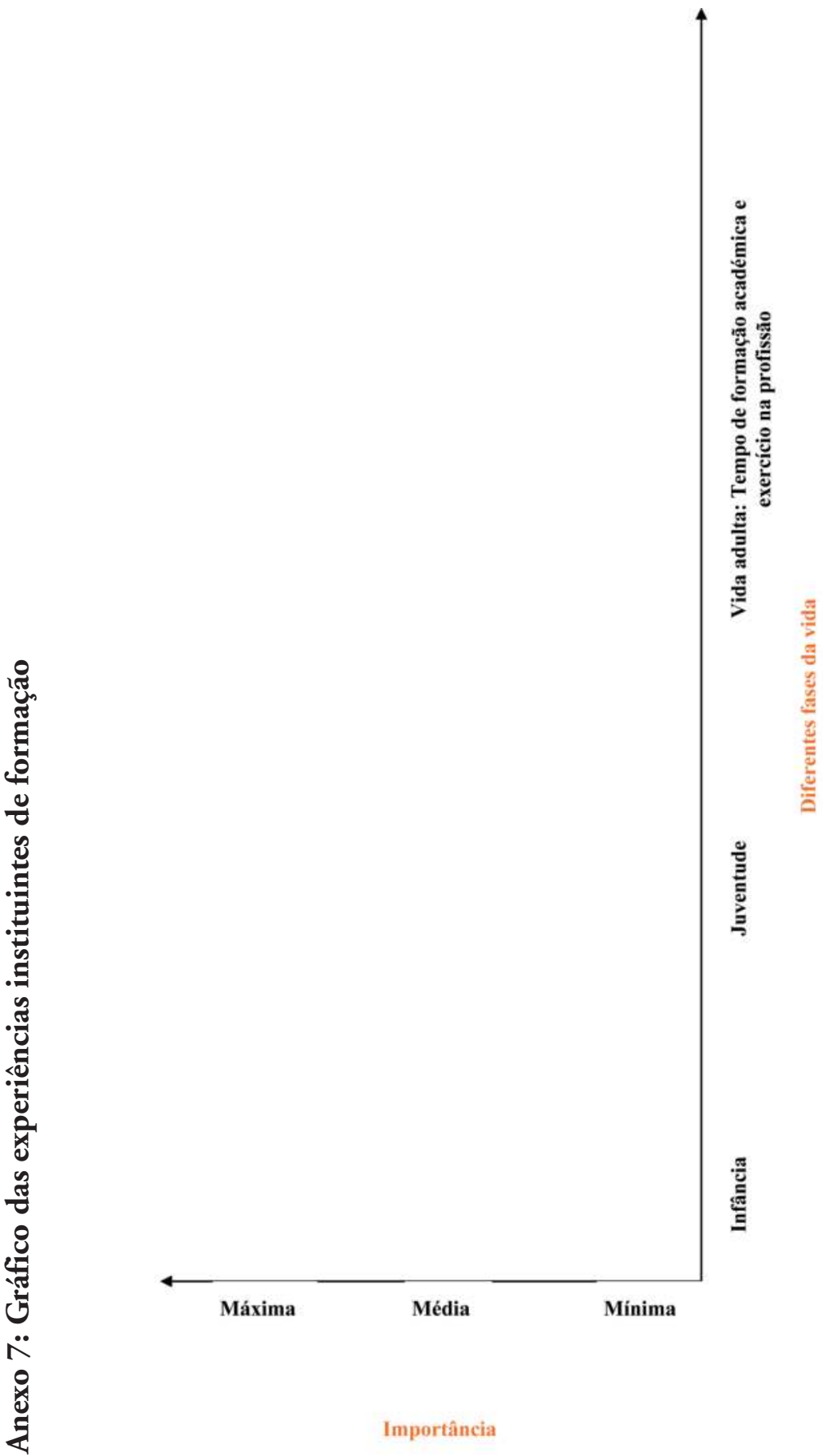


\section{Anexo 8: Carta de cessão}

\section{Professoras portuguesas}

$\mathrm{Eu}$, bilhete de identidade $\mathrm{n}$. , declaro para os devidos fins que cedo os direitos das entrevistas biográficas realizadas no contexto da investigação intitulada Histórias de vida e formação de professores/as, para a professora Inês Ferreira de Souza Bragança, aluna do doutoramento da Universidade de Évora e professora do Departamento de Educação da Faculdade de Formação de Professores da Universidade do Estado do Rio de Janeiro, matrícula n. 33715-4, com objetivo de sua utilização, integralmente ou em partes, sem restrições de prazos, para sua tese de doutorado, bem como em trabalhos académicos de natureza essencialmente pedagógica, de formação e pesquisa, incluindo comunicações orais e/ou publicações.

Autorizo, ainda, a publicação em livros, artigos e trabalhos científicos do texto integral da "biografia educativa" escrito pela referida professora, do qual tomei conhecimento.

Assinatura

Portugal, de de 2007. 


\section{Índice de quadros}

Quadro 1: Abordagem (auto)biográfica: diversidade de aportes teórico-metodológicos no campo das ciências sociais e humanas .............. 77

Quadro 2: Diversidade de procedimentos técnico-metodológicos .......... 79

Quadro 3: Data de nascimento e do início aproximado na

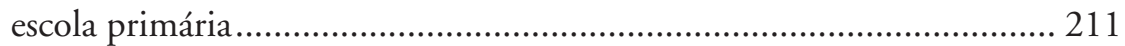

Quadro 4: Formação acadêmica das professoras participantes ............... 227

\section{Índice de figuras}

Figura 1: Contribuições no campo educativo e na formação de adultos: principais ênfases da literatura estudada .................................................. 85

Figura 2: Contribuições ligadas à formação docente ................................. 91

Figura 3: Socialização primária e secundária ........................................... 195

Figura 4: Acontecimentos biográficos comuns na formação

pessoal - infância .................................................................................. 209

Figura 5: Acontecimentos biográficos comuns na formação pessoal - juventude e vida adulta ......................................................... 210

Figura 6: Acontecimentos biográficos que mais se destacam na formação das professoras participantes da investigação-formação 258 


\section{Sobre a autora}

Inês Ferreira de Souza Bragança é pedagoga (1992). Especialista (1994) e mestre (1997) em Educação pela Universidade Federal Fluminense (UFF). Doutora em Ciências da Educação pela Universidade de Évora - Portugal (2009). Professora adjunta do Departamento de Educação e do Mestrado em Educação: Processos Formativos e Desigualdades Sociais da Faculdade de Formação de Professores da Universidade do Estado do Rio de Janeiro (FFP/UERJ) e do Programa de Pós-Graduação em Educação da Universidade Estácio de Sá (UNESA). Faz parte do Núcleo de Pesquisa e Extensão Vozes da Educação: Memória e História das Escolas de São Gonçalo (UERJ), do Grupo de Pesquisa ALEPH - Programa de Pesquisa, Aprendizagem-Ensino e Extensão em Formação dos Profissionais da Educação (UFF) e do Centro de Investigação em Educação e Psicologia da Universidade de Évora - Portugal (CIEP/UE). Dedica-se a pesquisas sobre formação docente, histórias de vida de professores/as, memória e história das escolas. 